INSTITUTO DE PESQUISAS ENERGÉTICAS E NUCLEARES

Autarquia associada à Universidade de São Paulo

BIOMECÂNICA APLICADA NA AVALIAÇÃO DE PROPRIEDADES DE IMPLANTES ORTOPÉDICOS METÁLICOS TRATADOS POR FEIXE LASER

EURICO FELIX PIERETTI

Tese apresentada como parte dos requisitos para obtenção do grau de Doutor em Ciências na Área de Tecnologia Nuclear - Materiais

Orientador: Dr. Maurício David Martins das Neves

São Paulo

2016 


\section{AGRADECIMENTOS}

A Deus, por me acompanhar pelos caminhos desta vida.

Ao Prof. Dr. Maurício David Martins das Neves, por acreditar neste ideal; pela orientação, confiança, motivação, disponibilidade, tempo investido.

Ao Engenheiro Ricardo Luiz Ciuccio, pela inestimável contribuição despendida em várias etapas desta pesquisa.

Ao Engenheiro Tomaz Puga Leivas, da Comissão de Projetos do Instituto de Ortopedia e Traumatologia do HCFMUSP, pela amizade e colaboração.

Ao Prof. Dr. Raul Bolliger Neto, do Instituto de Ortopedia e Traumatologia do HCFMUSP, pela valiosa disponibilidade, cordialidade, discussões e sugestões.

Ao Sr. Paulo Rigolo, da Hexagon Brasil, pelo fornecimento deste biomaterial.

Aos Engenheiros Carsten Keim e Carlos Ferreira, da Trumpf, pela disponibilidade e colaboração com as técnicas de tratamento com feixe laser de fibra óptica.

Ao Prof. Dr. Lalgudi Venkataraman Ramanathan, pelo conhecimento adquirido.

Ao Prof. Dr. Luís Frederico Pinheiro Dick, do Departamento de Engenharia Metalúrgica da UFRGS e, aos mestres Álvaro Pritzel dos Santos e Sara Matte Manhabosco, pela amizade, parceria e realização dos ensaios de SVET.

À Dra. Marina Fuser Pillis, do CCTM - IPEN, por permitir a utilização dos equipamentos alocados em seus laboratórios.

Ao Dr. Renato Altobelli Antunes, da UFABC, pela amizade e, por conceder parte da infra-estrutura de seus laboratórios para a conclusão desta pesquisa.

Ao Dr. Ronaldo Câmara Cozza, da FEI, pelos ensaios de desgaste. 
Ao Dr. Ramon Valls Martin, do IPT, por participar de várias etapas deste processo com sugestões e, pelos resultados no campo de metrologia magnética.

Ao Dr. Nelson Batista de Lima, do CCTM - IPEN, pela colaboração com as medidas de difração de raios $\mathrm{X}$ e textura.

À Profa. Dra. Olga Zazuco Higa, do CB - IPEN, e à Dra. Andrea Cecília Dorión Rodas, da UFABC, pela gentileza em conduzir os ensaios de biocompatibilidade.

À Profa. Dra. Maria Cecília Barbosa da Silveira Salvadori, do Instituto de Física da USP, pela gentileza e grande colaboração com a realização da técnica de MFM.

À Dra. Mitiko Saiki, do CRPq - IPEN, pelas análises de ativação neutrônica.

Ao Dr. Wagner de Rossi, do CLA -IPEN, pela disponibilização de equipamentos.

Aos Drs. Sérgio Luiz de Assis e Maysa Terada pelo auxílio com os CEE’s.

Ao Engenheiro Leonardo José Alves pelo auxílio com o projeto dos corpos-deprova em CAD, e ao Sr. Fernando Bento de Oliveira, da JF Polimentos de Moldes, pela colaboração com este trabalho.

Ao Departamento de Engenharia Mecânica da Escola Politécnica da USP pela realização do ensaio de fadiga.

Ao IPEN e seus funcionários pela possibilidade de execução deste trabalho.

Ao amigo Olandir Vercíno Corrêa, pela inesgotável contribuição em meio aos desafios da Ciência e Engenharia de Materiais no Brasil.

À minha família, pela dedicação, apoio e incentivo à minha formação; por contribuir para suscitar em mim o interesse pela pesquisa científica. 
“Como não podemos mudar a realidade, deixe-nos mudar os olhos com os quais a vemos"

Nikos Kazantzakis 


\title{
BIOMECÂNICA APLICADA NA AVALIAÇÃO DE PROPRIEDADES DE IMPLANTES ORTOPÉDICOS METÁLICOS TRATADOS POR FEIXE LASER
}

\author{
Eurico Felix Pieretti
}

\section{RESUMO}

A marcação por feixe laser em superfícies é utilizada para assegurar a identificação e a rastreabilidade em biomateriais. A texturização via feixe laser confere maior aderência às superfícies dos dispositivos médicos implantáveis. Este trabalho teve o objetivo de avaliar o comportamento da superfície do aço inoxidável austenítico ABNT NBR ISO 5832-1 submetido à marcação e texturização com feixe laser de fibra óptica, alterando-se a frequência dos pulsos; frente ao seu comportamento biomecânico, por meio de: ensaios de resistência à tração, fadiga e desgaste; verificar a susceptibilidade à corrosão localizada, por ensaios eletroquímicos em solução que simula os fluidos corpóreos; e caracterizar a sua microestrutura. Os tratamentos alteraram a rugosidade e a dureza dos biomateriais em função do aumento da frequência dos pulsos. A microestrutura e composição química das superfícies sofreram mudanças que afetaram diretamente a camada passiva dos aços inoxidáveis. Este efeito foi comprovado com o uso de SVET, XPS e caracterização de propriedades eletrônicas do filme passivo. Os dois tipos de tratamentos implicaram em aumento de susceptibilidade magnética das superfícies. Os parâmetros utilizados para as marcações e texturizações não causaram diminuição na viabilidade celular, de modo que não apresentou citotoxicidade mesmo após incubação prolongada. Este biomaterial mostrou-se adequado perante os ensaios biomecânicos, uma vez que os tratamentos a laser, nas condições utilizadas, não induziram a formação de tensões superficiais de magnitude capaz de levar à fratura por fadiga, indicando vida em fadiga infinita; tampouco se pôde relacionar a região de fratura por tração com as marcações a laser. O volume de desgaste diminuiu em função do aumento da dureza produzido pela elevação da frequência do pulso nas texturizações. O caráter visual das marcações e texturizações por feixe laser foi assegurado após a maioria dos ensaios realizados. 


\title{
APPLIED BIOMECHANICS TO EVALUATE THE PROPERTIES OF LASER BEAM TREATED ORTHOPEDIC IMPLANTS
}

\author{
Eurico Felix Pieretti
}

\begin{abstract}
Laser beam marking is used to ensure biomaterials' identification and traceability. The texturing imparts greater adhesion to the surfaces of implantable medical devices. The aim of this work was to evaluate the surface behaviour of the austenitic stainless steel ABNT NBR ISO 5832-1 marked and textured by optical fiber laser beam using selected parameters, changing the pulse frequency; in face of its biomechanical behaviour, through tests of tensile strength, fatigue and wear; verify the localized corrosion susceptibility by electrochemical tests in a solution that simulates the body fluids; and analyze microstructural changes. The treatments performed altered the biomaterials roughness and their micro hardness as a function of the increase of the pulse frequency. The microstructure and chemical composition of the surfaces underwent changes that directly affected the passive layer of the stainless steels, triggering the corrosion process. This effect was evidenced by SVET, XPS and characterization of electronic properties of the passive film by the Mott-Schottky technique. These two types of laser treatments increased the surfaces' magnetic susceptibility. The parameters used for the marking and texturing did not induce a decrease in the cellular viability of the samples, as no cytotoxicity was showed even after prolonged incubation. This biomaterial was adequate on the biomechanical tests, since the laser treatments, under the conditions used, did not induce the formation of surface tensions of magnitude capable of leading the fatigue fracture, indicating infinite fatigue life; the region of fracture by tension could not be related to the laser marking. The wear volume decreased as a function of the increase in micro hardness produced by the increase of the pulse frequency in the texturings. The visual character of the markings and texturings was assured after the majority of the tests performed.
\end{abstract}


RESUMO

ABSTRACT

1. INTRODUÇÃO

2. OBJETIVO

3. REVISÃO BIBLIOGRÁFICA 4

3.1. Biomateriais 4

3.2. Biocompatibilidade 6

3.3. Materiais Metálicos $\quad 7$

3.3.1. Aços Inoxidáveis 7

3.3.2. Aços Inoxidáveis Austeníticos 8

3.3.3. Aço ABNT NBR ISO 5832-1 8

3.4. Tratamentos de Superfície 9

3.4.1. Marcação e Texturização de Implantes Ortopédicos 10

3.5. Interação do Feixe Laser com a Matéria 12

3.5.1. Princípios Básicos da Tecnologia do Laser 12

3.5.2. Marcação de Aços Inoxidáveis por Feixe Laser 15

3.6. Efeitos Causadores de Falhas em Implantes Ortopédicos 16

3.6.1. Fadiga 16

$\begin{array}{ll}\text { 3.6.2. Desgaste } & 21\end{array}$ 
3.6.3. Corrosão 22

3.7. Mecanismos de Corrosão 22

3.7.1. Corrosão por Pite 22

3.7.2. Características do Filme Passivo em Aços Inoxidáveis 23

3.7.3. Propriedades Eletrônicas do Filme Passivo em Aços Inoxidáveis 24

3.7.4. Espectroscopia de Impedância Eletroquímica (EIE) com 28 Modelamento via Circuitos Elétricos Equivalentes (CEE)

3.7.5. Técnica Eletroquímica Localizada - SVET 29

3.8. Biomecânica do Movimento Humano 30

3.8.1. Fatores que Acarretam no Uso de Biomateriais 30

3.8.2. Substituição de Articulações 31

3.8.3. Ensaios Biomecânicos de Biomateriais 32

4. MATERIAIS E MÉTODOS 34

4.1. Material 34

4.2. Tratamentos Superficiais 34

4.3. Análises Microestruturais 35

4.3.1. Microscopia Óptica (MO) 35

4.3.2. Microscopia Eletrônica de Varredura (MEV) 36

4.3.3. Microscopia de Alta Resolução (Field Emission Gun)-(SEM-FEG) 36

4.3.4. Microscopia Confocal 37

4.4. Análises Topográficas 37

4.5. Análises de Microdureza 38

4.6. Difração de Raios X (DRX) 38

4.7. Espectrometria de Fluorescência de Raios X (FRX) 38

4.8. Análises de Textura 39

4.9. Ensaios Eletroquímicos 39

4.9.1. Potencial de Circuito Aberto (PCA) 40

4.9.2. Espectroscopia de Impedância Eletroquímica (EIE) 40

4.9.3. Polarização Potenciodinâmica Cíclica 41

4.9.4. Abordagem de Mott-Schottky para Avaliação de Propriedades 42 Eletrônicas do Filme Passivo

4.9.5. Técnica Eletroquímica de Varredura com Eletrodo Vibrante- SVET 42

4.10. Espectroscopia de Fotoelétrons Excitados por Raios X (XPS) 43

4.11. Análise por Ativação Neutrônica 44 
4.12. Caracterização Magnética 44

4.12.1. Técnica de Análise de Permeabilidade Magnética 44

4.12.2. Técnica de Microscopia de Força Magnética (MFM) 45

4.13. Ensaios Biomecânicos dos Biomateriais 46

4.13.1. Resistência à Fadiga 47

4.13.2. Resistência à Tração $\quad 47$

4.13.3. Resistência ao Desgaste 47

4.13.4. Resistência ao Desgaste em Nanotribômetro 48

4.13.5. Análise de Superfície de Fratura e Cratera de Desgaste 49

4.14 Ensaio de Citotoxicidade 49

5. RESULTADOS E DISCUSSÃO 51

5.1. Avaliações Macrográficas 51

5.2. Análises Microestruturais 52

5.3. Análise Química 53

5.4. Análises Topográficas 54

5.5. Avaliação de Rugosidades 56

5.6. Avaliação de Microdureza 58

5.7. Caracterização das Superfícies 60

5.8. Difração de Raios X 73

$\begin{array}{lll}\text { 5.9. Textura } & 74\end{array}$

5.10. Técnica Eletroquímica de Varredura com Eletrodo Vibrante 75

5.11. Potencial de circuito aberto 82

5.12. Polarização Potenciodinâmica Cíclica 85

5.13. Análises das Superfícies das Amostras Polarizadas 91

5.14. Espectroscopia de Impedância Eletroquímica 96

5.15. Propriedades Eletrônicas do Filme Passivo 104

5.16. Caracterização do Filme Passivo por Espectroscopia de 112 Fotoelétrons Excitados por Raios X (XPS)

5.17. Análises por Ativação Neutrônica 115

5.18. Características Produzidas pelo Laser na Superfície do 117 Biomaterial

5.19. Análises de Propriedades Biomecânicas do Biomaterial 131

5.19.1. Ensaios de Fadiga 132

5.19.2. Ensaios de Tração 134 
5.19.3. Ensaios Tribológicos 136

5.20. Avaliação de Citotoxicidade 143

5.21. Avaliação de Susceptibilidade Magnética 145

5.22. Caracterização de Campo Magnético por Microscopia de Força 147 Magnética (MFM)

6. CONCLUSÕES

7. SUGESTÕES PARA TRABALHOS FUTUROS

APÊNDICE 


\section{LISTA DE TABELAS}

Página

Tabela 1. Elementos químicos presentes na amostra do aço 34 inoxidável ABNT NBR ISO 5832-1, obtida por espectroscopia de emissão óptica

Tabela 2. Parâmetros do laser utilizados para as marcações e texturizações

Tabela 3. Composição química $(\mathrm{g} / \mathrm{L})$ da solução salina de fosfato tamponada (PBS)

Tabela 4. Elementos químicos presentes na amostra do aço inoxidável ABNT NBR ISO 5832-1, pela técnica de espectrometria de fluorescência de raios $X$

Tabela 5. Valores de rugosidades $(\mu \mathrm{m})$ obtidos por rugosímetro convencional para as amostras apresentadas nas Figura 5.1 (a) e (b)

Tabela 6. Valores de rugosidades $(\mu \mathrm{m})$ obtidos por MEV de baixo vácuo com software de análise topográfica para as diferentes condições de texturização a laser para as amostras apresentadas na Figura 5.1(b)

Tabela 7. Medidas de microdureza Vickers para cada tipo de acabamento superficial de texturização por feixe laser e amostra padrão.

Tabela 8. Rugosidades para as amostras texturizadas a laser nas direções paralelas e perpendiculares à trajetória produzida pelo feixe

Tabela 9. Valores médios das larguras dos tracejados produzidos pelo feixe laser, obtidos por perfilometria, para as amostras texturizadas

Tabela 10. Valores dos principais parâmetros do feixe laser calculados para cada condição de acabamento superficial

Tabela 11. Valores de potenciais de corrosão e de pite, correntes de 40 corrosão, $\beta a$ e $\beta c$ para amostras com marcações e texturizações a laser, e padrão

Tabela 12. Valores dos parâmetros ajustados utilizando os circuitos mostrados na Figura 50 (a) e (b) para o aço inoxidável austenítico ABNT NBR ISO 5832-1, nas três condições estudadas

Tabela 13. Valores de potenciais de banda plana Ebp (V) para doadores e aceitadores de carga

Tabela 14. Composição química (\% atômica), obtidas por XPS, das superfícies das amostras texturizadas e padrão

Tabela 15. Determinação de elementos químicos em amostras de extratos de solução de PBS após polarização cíclica pelo método de analise por ativação com nêutrons

Tabela 16. Composição química (\% em massa) obtida por EDS dos elementos encontrados nos pontos selecionados na imagem da Figura 5.15.6 
Tabela 17. Propriedades físicas dos elementos químicos do aço

131 inoxidável austenítico estudado

Tabela 18. Medidas de força e permeabilidade magnética para as 146 amostras marcadas e texturizadas a laser

Tabela 19. Comparação entre as faces texturizadas e marcadas por 146 feixe laser nos parâmetros das amostras 1, 2, 3 e 4 


\section{LISTA DE FIGURAS}

Página

Figura 1

Figura 2

Figura 3

Figura 4

Figura 5

Figura 6

Figura 7

Figura 8

Figura 9

Figura 10

Figura 11

Figura 12

Figura 13

Figura 14

Figura 15

Figura 16

Figura 17

Figura 18
Implantes ortopédicos para substituição total de articulação do quadril

Marcação em implante ortopédico metálico

11

A energia (área sombreada) é produzida em pacotes concentrados por um laser pulsado

llustração da secção transversal da superfície de um biomaterial metálico deformado, mostrando as complexas interações entre a superfície do material e o meio fisiológico

Resistência à fadiga de algumas das ligas metálicas mais utilizadas para implantes ortopédicos

Representação esquemática do processo de difusão através da dupla camada do filme passivante

Representação esquemática da abordagem de MottSchottky para a estrutura eletrônica dos óxidos formados em aços inoxidáveis e em ligas de $\mathrm{Fe}-\mathrm{Cr}$; onde $\mathrm{E}_{\mathrm{F}}$ corresponde ao nível de Energia de Fermi e $E_{b p}$ ao potencial de banda plana

Microscópio confocal

Célula plana de três eletrodos utilizada para os ensaios eletroquímicos

Equipamento para ensaio de tração. A seta aponta a região de fratura do corpo-de-prova

20

25

27

40

47

Equipamento para ensaio de desgaste por esfera livre rotativa

Equipamento para ensaio de nanotribologia

Amostras marcadas e texturizadas a laser

51

Micrografia obtida por microscopia eletrônica de varredura

52 da amostra do aço inoxidável estudado após ataque eletrolítico em ácido oxálico, 10\% V, 1 min.

Topografia dos biomateriais sem tratamento e texturizados a laser com os parâmetros pré-definidos, aumentando-se a frequência do laser, conforme designado pela sequência de 1 a 4

Microscopias ópticas das superfícies das amostras texturizadas por laser e padrão de referência, apresentando região de penetração da ponteira de microdureza Vickers. Sem ataque

Imagem obtida por MEV de baixo vácuo da superfície do aço inoxidável como recebido, sem tratamento a laser $\mathrm{e}$ sem ataque. Aumento $40 x$

Imagens obtidas por MEV de baixo vácuo das superfícies do aço inoxidável ABNT NBR ISO 5832-1 após tratamento de texturização a laser e sem ataque 11 14

\section{4}


Figura 19 Imagem das amostras obtidas por MEV da superfície do aço inoxidável ABNT NBR ISO 5832-1 após tratamento de marcação a laser. Ataque via água régia.

Figura 20 Microscopia confocal das superfícies texturizadas a laser e padrão

Figura 21 Perfil de rugosidade da superfície das amostras com texturização a laser

Figura 22 Ampliação esquemática da região analisada por 69 perfilometria (linha amarela). Largura dos tracejados produzidos na texturização por feixe laser

Figura 23 Diagrama de diâmetros em função de energia dos pulsos para cada condição avaliada

Figura 24 Diagrama de intensidades em função do tempo dos pulsos para cada condição avaliada

Figura 25 Figuras de pólo para as amostras na condição padrão para as direções: (a) [111], (b) [220] e (c) [200].

Figura 26 Microscopia óptica da região da amostra 1 selecionada para análise e mapas gerados por SVET em função do tempo de imersão em PBS no PCA.

Figura $27 \quad$ Microscopia óptica da região da amostra 2 selecionada para análise e mapas gerados por SVET em função do tempo de imersão em PBS no PCA.

Figura 28 Microscopia óptica da região da amostra 3 selecionada para análise e mapas gerados por SVET em função do tempo de imersão em PBS no PCA.

Figura 29 Microscopia óptica da região da amostra 4 selecionada para análise e mapas gerados por SVET em função do tempo de imersão em PBS no PCA.

Figura 30 Potencial de corrosão em circuito aberto variando ao longo do tempo em solução PBS, naturalmente aerada a $37^{\circ} \mathrm{C}$ nas condições: padrão e com marcações a laser.

Figura 31 Potencial de corrosão em circuito aberto variando ao longo do tempo em solução PBS, naturalmente aerada a $37^{\circ} \mathrm{C}$ nas condições: padrão e com texturizações a laser.

Figura 32 Curvas de polarização cíclica obtidas no sentido anódico para o aço inoxidável austenítico ABNT NBR ISO 5832-1 em PBS a $37^{\circ} \mathrm{C}$ para amostras marcadas a laser e padrão

Figura 33 Curvas de polarização cíclica obtidas no sentido anódico para o aço inoxidável austenítico ABNT NBR ISO 5832-1 em PBS a $37^{\circ} \mathrm{C}$ para amostras texturizadas a laser e padrão

Figura $34 \quad$ Curvas de polarização cíclica obtidas no sentido anódico para o aço inoxidável austenítico ABNT NBR ISO 5832-1 em PBS a $37^{\circ} \mathrm{C}$ para a amostra 1 nas três condições de acabamento superficial.

Figura $35 \quad$ Curvas de polarização cíclica obtidas no sentido anódico para o aço inoxidável austenítico ABNT NBR ISO 5832-1 em PBS a $37^{\circ} \mathrm{C}$ para a amostra 2 nas três condições de acabamento superficial.

Figura 36 Curvas de polarização cíclica obtidas no sentido anódico 
para o aço inoxidável austenítico ABNT NBR ISO 5832-1 em PBS a $37^{\circ} \mathrm{C}$ para a amostra 3 nas três condições de acabamento superficial.

Figura $37 \quad$ Curvas de polarização cíclica obtidas no sentido anódico para o aço inoxidável austenítico ABNT NBR ISO 5832-1 em PBS a $37^{\circ} \mathrm{C}$ para a amostra 4 nas três condições de acabamento superficial.

Figura 38 Microscopia eletrônica de varredura do aço inoxidável ABNT NBR ISO 5832-1 com marcação a laser, após o ensaio de polarização cíclica. Aumento: 60x.

Figura 39 Microscopia eletrônica de varredura mostrando região de fresta formada na borda esquerda na gravação a laser do número oito em uma amostra do aço inoxidável ABNT NBR ISO 5832-1, sem ataque metalográfico. Aumento: 60x

Figura 40 Amostra padrão de referência após polarização potenciodinâmica anódica, sem ataque metalográfico.

Figura 41 Imagem de fresta formada na amostra-2 com marcação a laser após ensaio de polarização potenciodinâmica anódica, sem ataque metalográfico

Figura 42 Imagem em 3D de pite formado na amostra-1 com marcação a laser após ensaio de polarização potenciodinâmica anódica, sem ataque metalográfico

Figura 43 Imagem em de pite formado na amostra-1 com texturização a laser após ensaio de polarização potenciodinâmica anódica, sem ataque metalográfico.

Figura 44 Diagrama de Bode (ângulo de fase) obtido após PCA para o aço inoxidável austenítico ABNT NBR ISO 5832-1em PBS a $37^{\circ} \mathrm{C}$, para as amostras marcadas a laser e padrão

Figura 45 Diagrama de Bode (módulo de Z) obtido após PCA para o aço inoxidável austenítico ABNT NBR ISO 5832-1em PBS a $37^{\circ} \mathrm{C}$, para as amostras marcadas a laser e padrão

Figura 46 Diagrama de Bode (ângulo de fase) obtido após PCA para o aço inoxidável austenítico ABNT NBR ISO 5832-1em PBS a $37^{\circ} \mathrm{C}$, para as amostras texturizadas a laser e padrão

Figura 47 Diagrama de Bode (módulo de Z) obtido após PCA para o aço inoxidável austenítico ABNT NBR ISO 5832-1em PBS a $37^{\circ} \mathrm{C}$, para as amostras texturizadas a laser e padrão

Figura 48 Diagrama de Nyquist obtido após PCA para o aço inoxidável austenítico ABNT NBR ISO 5832-1em PBS a $37^{\circ} \mathrm{C}$ para as amostras marcadas a laser e padrão

Figura 49 Diagrama de Nyquist obtido após PCA para o aço inoxidável austenítico ABNT NBR ISO 5832-1em PBS a $37^{\circ} \mathrm{C}$ para as amostras texturizadas a laser e padrão

Figura 50 Circuitos Elétricos Equivalentes (CEE) utilizados para ajustar os dados experimentais obtidos por EIE para o aço inoxidável austenítico ABNT NBR ISO 5832-1, para as condições: (a) sem marcação e com marcação a laser e (b) com texturização por feixe laser.

Figura 51 Gráficos de Mott-Schottky para amostras do aço inoxidável 
Figura 52

Figura 53

Figura 54

Figura 55

Figura 56

Figura 57

Figura 58

Figura 59

Figura 60

Figura 61

Figura 62

Figura 63

Figura 64

Figura 65

Figura 66

Figura 67 austenítico ABNT NBR ISO 5832-1 em PBS, a $37^{\circ} \mathrm{C}$, para amostras marcadas a laser e padrão, imersas por $12 \mathrm{~h}$ Gráficos de Mott-Schottky para amostras do aço inoxidável austenítico ABNT NBR ISO 5832-1 em PBS, a $37^{\circ} \mathrm{C}$, para amostras texturizadas a laser e padrão, imersas por $12 \mathrm{~h}$

Valores de doadores de carga no filme passivo, obtidos pelo gráfico de Mott-Schottky, na região de potenciais referentes à inclinação positiva (comportamento de um semicondutor tipo-n) para amostras com marcações a laser

Valores de doadores de carga no filme passivo, obtidos pelo gráfico de Mott-Schottky, na região de potenciais referentes à inclinação positiva (comportamento de um semicondutor tipo-n), para amostras com texturizações a laser

Valores de aceitadores de carga no filme passivo, obtidos pelo gráfico de Mott-Schottky, na região de potenciais referentes à inclinação negativa (comportamento de um semicondutor tipo-p), para amostras com marcações

Valores de aceitadores de carga no filme passivo, obtidos pelo gráfico de Mott-Schottky, na região de potenciais referentes à inclinação negativa (comportamento de um semicondutor tipo-p), para amostras com texturizações a laser e padrão

Valores de doadores de carga no filme passivo, obtidos pelo gráfico de Mott-Schottky, na região de potenciais referentes à inclinação positiva (comportamento de um semicondutor tipo-n), para amostras nas três condições analisadas

Valores de aceitadores de carga no filme passivo, obtidos pelo gráfico de Mott-Schottky, na região de potenciais referentes à inclinação negativa (comportamento de um semicondutor tipo-p), para amostras nas três condições analisadas

Espectro de XPS da amostra padrão

Distribuição de elementos químicos presentes em área de 2,0 $\mathrm{mm}^{2}$ do filme passivo formado na superfície da amostra 1, obtido por XPS

Regiões da amostra-1 analisadas por pontos e por linha

Espectro de EDS para o ponto-1, região da marcação a laser

Espectro de EDS para o ponto-4, região sem laser

Mapeamento em linha da distribuição dos elementos químicos presentes na superfície da amostra-1

Regiões da amostra-2 analisadas por pontos e por linha

Espectro de EDS para o ponto-2, região termicamente afetada pelo laser 
Figura 68

Figura 69

Figura 70

Figura 71

Figura 72

Figura 73

Figura 74

Figura 75

Figura 76

Figura 77

Figura 78

Figura 79

Figura 80

Figura 81

Figura 82

Figura 83

Figura 84

Figura 85

Figura 86

Figura 87

Figura 88

Figura 89

Figura 90

Figura 91
Mapeamento em linha da distribuição dos elementos químicos presentes na superfície da amostra-2

Regiões da amostra-3 analisadas por pontos e por linha

Espectro de EDS para o ponto-3, região marcada a laser

Espectro de EDS para o ponto-4, região sem marcação

Mapeamento em linha da distribuição dos elementos químicos presentes na superfície da amostra-3

122

Regiões da amostra-4 analisadas por pontos e por linha

122

Espectro de EDS para o ponto-1, região termicamente afetada pelo feixe laser

Espectro de EDS para o ponto-6, região de incidência do feixe laser

Mapeamento em linha da distribuição dos elementos químicos presentes na superfície da amostra-4

Região de transição pico-vale (1) da amostra-4 analisada por linha

Mapeamento em linha da distribuição dos elementos químicos presentes na superfície da amostra-4, região pico-vale (1)

Região de transição pico-vale (2) da amostra-4 analisada por linha

Mapeamento em linha da distribuição dos elementos químicos presentes na superfície da amostra-4, região pico-vale (2)

Região de transição pico-vale (3) da amostra-4 analisada por linha

Mapeamento em linha da distribuição dos elementos químicos presentes na superfície da amostra-4, região pico-vale (3)

Região de transição pico-vale (4) da amostra-4 analisada por linha

Mapeamento em linha da distribuição dos elementos químicos presentes na superfície da amostra-4, região pico-vale (4)

Região de transição pico-vale (5) da amostra-4 analisada por linha

Mapeamento em linha da distribuição dos elementos químicos presentes na superfície da amostra-4, região pico-vale (5)

Regiões da amostra-4 analisadas por pontos.

Corpo-de-prova marcado a laser durante ensaio de fadiga

Imagens do corpo-de-prova marcado a laser antes do ensaio de fadiga (acima) e após o ensaio (abaixo)

Gráfico: Força [N] versus Deformação [mm] para as três condições de acabamento superficial analisadas

Gráfico Tensão [MPa] versus Deformação para as três condições de acabamento superficial analisadas 
Figura 92

Figura 93

Figura 94

Figura 95

Figura 96

Figura 97

Figura 98

Figura 99

Figura 100

Figura 101

Figura 102

Figura 103

Figura 104

Figura 105

Figura 106

Figura 107

Figura 108

Figura 109

Figura 110

Figura 111

Figura 112
Fraturas dos corpos-de-prova de tração texturizado, marcado e padrão

Valores de volume de desgaste em função do tipo de acabamento superficial

Valores de coeficiente de atrito em função do tipo de acabamento superficial para a amostra padrão e tratadas por feixe laser

Imagem de cratera de desgaste gerada na superfície da amostra padrão.

Valores de coeficiente de atrito em função da variação do parâmetro do laser para as amostras texturizadas e padrão de referência

Valores de coeficiente de atrito em função da variação do parâmetro do laser para as amostras marcadas e amostra padrão de referência

Variação de coeficiente de atrito $[\mu]$ em função do tempo [s] de ensaio para as amostras texturizadas a laser e padrão

Variação de coeficiente de atrito $[\mu]$ em função do tempo [s] de ensaio para as amostras marcadas a laser e padrão

Gráfico de viabilidade celular (\%) por tipo de amostra

Regiões das superfícies dos biomateriais texturizadas a laser, selecionadas para análise por MFM e detalhe da sonda

Imagem obtida por AFM (tapping mode) da topografia (alturas) da região analisada na superfície da amostra 1

Imagem obtida por MFM da amplitude do campo magnético detectado na região selecionada na superfície da amostra 1

Imagem da amplitude do campo magnético detectado na região selecionada na superfície da amostra 1 . Medida em região adjacente à apresentada anteriormente

Imagem da diferença de fases detectada na superfície da amostra 1

Imagem da frequência do sinal do campo magnético presente na amostra 1

Imagem obtida por AFM (tapping mode) da topografia (alturas) da região analisada na superfície da amostra 2

Imagem obtida por MFM da amplitude do campo magnético detectado na região selecionada na superfície da amostra 2

Imagem da diferença de fases detectada na superfície da amostra 2

Imagem obtida por AFM (tapping mode) da topografia (alturas) da região analisada na superfície da amostra 3

Imagem obtida por MFM da amplitude do campo magnético detectado na região selecionada na superfície da amostra 3

Imagem da diferença de fases detectada na superfície da amostra 3

136

137

138

138

139

140

142

142

148

149 
Figura 113 Imagem obtida por AFM (tapping mode) da topografia 156 (alturas) da região analisada na superfície da amostra 4

Figura 114 Imagem obtida por MFM da amplitude do campo 156 magnético detectado na região selecionada na superfície da amostra 4

Figura 115 Imagem da diferença de fases detectada na superfície da 157 amostra 4 


\section{INTRODUÇÃO}

A fratura e o desgaste ósseo são, em grande parte, originados do crescente número de acidentes com lesões graves e do aumento da expectativa de vida da população, acarretando em um aumento do número de cirurgias e incrementando o desenvolvimento de implantes ortopédicos e odontológicos. Estes implantes são fabricados com biomateriais que substituem ou auxiliam tecidos, órgãos ou funções do corpo humano para que estes possam desempenhar as suas atribuições adequadamente. Estes materiais devem ter composição química e propriedades superficiais adequadas, de forma que não ocorra a soltura durante o período em que estiverem implantados.

As marcações em implantes possuem a finalidade de proporcionar uma informação ou um conjunto de informações permanentes sobre o dispositivo, de modo a assegurar a identificação e rastreabilidade do produto [1]. As texturizações garantem um acabamento superficial apropriado para a fixação.

Em relação às técnicas de marcação existentes, o método por feixe laser tem sido utilizado para biomateriais metálicos, pois possibilita um elevado grau de automatização, alta velocidade de varredura, excelente reprodutibilidade, alta durabilidade, limpeza e não acarreta em desgaste para o ferramental.

Dentre o rol de biomateriais metálicos existentes destacam-se os aços inoxidáveis austeníticos, por possuírem uma combinação razoável entre propriedades físicas, eletroquímicas, metalúrgicas e mecânicas associado ao custo mais acessível, o que deve ser muito considerado em países, como o Brasil, onde um expressivo montante do total de cirurgias ortopédicas é custeado pelo Sistema Único de Saúde (SUS).

O comportamento eletroquímico do biomaterial é profundamente influenciado pela sua condição de superfície, visto que a região submetida ao feixe laser se torna essencialmente anódica [2, 3]. É sabido, todavia, que esta técnica produz aquecimento, ablação, fusão e evaporação de elementos químicos da superfície do biomaterial em regiões muito localizadas, podendo gerar uma região submetida a solidificação e resfriamento fora das condições de equilíbrio, provocando uma zona termicamente afetada muito pequena.

A aplicação em dispositivos ortopédicos implantáveis restringe o seu uso em biomateriais metálicos isentos de fase ferromagnética. Especificamente, no 
caso de implantes produzidos em ligas de aços inoxidáveis austeníticos, são escassas na literatura pesquisas acerca da possibilidade de formação de fase ferromagnética devido ao aquecimento e rápido resfriamento gerado na interação do feixe laser com a superfície do biomaterial.

Estes implantes, quando em contato com o tecido humano, estão sujeitos a falhas como desgaste, fadiga, micro movimentos, desprendimento de partículas e corrosão, podendo causar hipersensibilidade, ou a necessidade de novas cirurgias para remoção e substituição, contribuindo para o aumento de despesas para os setores da Saúde.

O tempo de vida útil de um dispositivo médico implantável varia conforme requisitos, tais como: idade do paciente, nível de atividade física, propriedades do biomaterial, degradação e falha do mesmo.

Os parâmetros biomecânicos para avaliação da marcha vêm apresentando um crescente desenvolvimento quanto à obtenção de medidas aplicadas às mais diversas situações, desde controle postural em crianças e idosos à otimização de exercícios físicos em atletas de alto rendimento; entretanto, existe pouca literatura envolvendo pesquisas que se valham da biomecânica dos biomateriais para desenvolver modelos que avaliem ou prevejam o comportamento de biomateriais metálicos para implantes ortopédicos submetidos a tratamento superficial de marcação e/ou texturização por feixe laser.

São escassas as pesquisas que comprovem a influência das marcações e texturizações por feixe laser em biomateriais associadas à caracterização de filmes passivos e de susceptibilidade magnética relacionadas às propriedades mecânicas e tribológicas, sendo estes os aspectos originais desta pesquisa.

Assim, os resultados deste trabalho devem permitir a previsão do comportamento dos dispositivos sob condições reais de utilização e podem servir como base para fornecer condições para a criação de uma normatização brasileira específica; tornando-se necessário o constante avanço em pesquisas acerca do comportamento biomecânico, bioeletroquímico e biotribológico para o desenvolvimento, processamento, caracterização e desempenho de novos biomateriais. 


\section{OBJETIVO}

Avaliar o efeito dos tratamentos de superfície de marcação e texturização por feixe laser de fibra óptica pulsado em implantes ortopédicos de aço inoxidável austenítico ABNT NBR ISO 5832-1. Caracterizar os fenômenos de superfície que influenciam nas suas propriedades de biocompatibilidade, de biomecânica da fadiga, da tração e da resistência ao desgaste; susceptibilidade à corrosão localizada, propriedades eletrônicas do filme passivo e formação de campo magnético. 


\section{REVISÃO BIBLIOGRÁFICA}

\subsection{Biomateriais}

Os biomateriais proporcionam uma melhoria na qualidade de vida das pessoas, representada por um aumento na longevidade, na saúde e no bem estar geral da população.

Os implantes ortopédicos são produzidos de forma que, quando usados sob as condições e para os propósitos projetados, não comprometam a condição clínica ou a segurança de pacientes e, quaisquer riscos que possam ser associados com o uso de implantes sejam pequenos, quando comparados aos benefícios para o paciente, além de serem compatíveis, com altos níveis de proteção e segurança [4 - 6]. Na Figura 1 está apresentado um conjunto de biomateriais utilizados para implantes ortopédicos para substituição total de articulação do quadril.

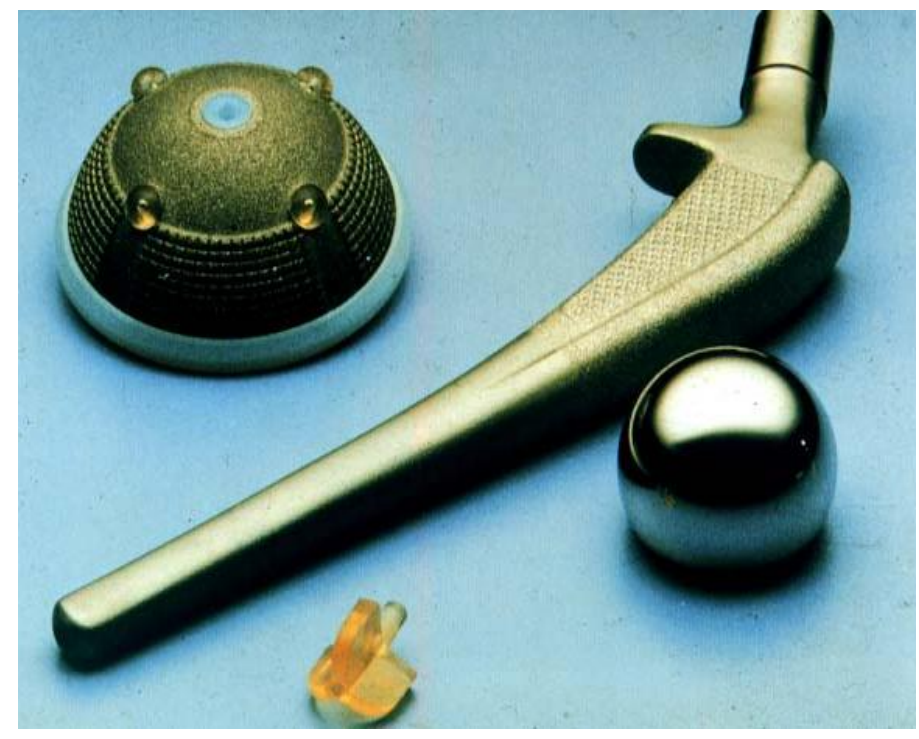

Figura 1. Implantes ortopédicos para substituição total de articulação do quadril. [Fonte: o autor].

Os implantes podem ser divididos em duas categorias: dispositivos de fixação temporária ou permanente. O propósito dos dispositivos de fixação temporária é a estabilização da fratura do osso até a sua consolidação natural; já os dispositivos de fixação permanente são implantados no lugar do osso fraturado, substituindo-o parcialmente ou totalmente [7]. De acordo com Anderson 
[8], para facilitar os testes de seleção do biomaterial, deve-se considerar a natureza do contato do dispositivo com a região do organismo em que deve ser utilizado e a duração deste contato.

A importância da qualidade do material empregado na fabricação de implantes de uso ortopédico vem crescendo, à medida que fica evidente a relação entre as propriedades físico-químicas do material e a ocorrência de falha do implante. Dentre o rol de ligas metálicas empregadas na produção de dispositivos médicos implantáveis destacam-se as ligas de: titânio, de cobalto-cromo e os aços inoxidáveis [9]. As cerâmicas podem ser divididas em duas classes: as bioinertes com boas propriedades mecânicas (alumina, zircônia) e as bioativas (hidroxiapatita, biovidros e beta-trifosfato de cálcio, por exemplo). Os materiais poliméricos possuem uma gama enorme de possibilidades, e podem ser divididos em bioreabsorvíveis e não- bioabsorvíveis.

Os biomateriais metálicos visam a atender, principalmente, as necessidades de substituição ou reparação de tecidos perdidos e/ou lesionados, atendendo a requisitos como biocompatibilidade e biofuncionalidade [8]. Existem vários materiais metálicos que são utilizados como implantes ortopédicos.

O aço inoxidável mais utilizado no Brasil, neste setor, é o aço inoxidável ABNT NBR ISO 5832-1 [9, 10]. Outros aços amplamente utilizados para a fabricação de implantes ortopédicos são: o aço inoxidável austenítico ASTM F138 e o ABNT NBR ISO 5832-9, [11, 12].

Ligas de cobalto e cromo (Co-Cr) e cobalto-cromo-molibdênio (Co-Cr-Mo), em razão de suas propriedades de biocompatibilidade e mecânicas, vêm sendo usadas na fabricação de próteses médicas e odontológicas [13].

As ligas de $\mathrm{Ti}$ apresentam algumas vantagens em relação aos demais metais, principalmente devido ao seu menor módulo elástico, baixa densidade relativa, altas biocompatibilidade e resistência à corrosão. Uma liga de titânio bastante utilizada é a liga Ti-6Al-4V, de módulo de elasticidade em torno de 110 GPa [14], originalmente desenvolvida para a indústria aeroespacial [15]. Entretanto, os elementos de liga, Al e $\mathrm{V}$ podem apresentar efeitos nocivos à saúde [16,17]. Assim, pesquisas estão sendo desenvolvidas para obtenção de novas ligas constituídas por elementos como, $\mathrm{Ti}, \mathrm{Nb}, \mathrm{Ta}$ e $\mathrm{Zr}$, que atendem aos critérios de biocompatibilidade, além de apresentarem excelente resistência à corrosão e módulo de elasticidade mais próximo ao do osso humano [18]. 
O tecido ósseo é o principal responsável por fornecer ao organismo estabilidade e sustentação, sendo, desta maneira, o agente receptor de todos os sistemas de implantes ortopédicos e dentais. Além de ser um tecido de sustentação altamente especializado, é capaz de modificar a sua própria arquitetura para atender a fatores físicos e hormonais.

A superfície do implante é um fator que influencia o processo de reparação óssea e embora implantes de superfície usinada tenham sido utilizados por muitos anos, estudos demonstram que o aumento da rugosidade tende a elevar a resistência de união da interface osso / implante [19].

\subsection{Biocompatibilidade}

A biocompatibilidade é definida como um estado sinérgico entre 0 biomaterial e o ambiente fisiológico, ou seja, o biomaterial a ser utilizado não deve desencadear reações adversas ao sistema biológico, desenvolvendo respostas teciduais adequadas aos sistemas hospedeiros. Um material biocompatível desempenha adequadamente a função para a qual foi projetado [5, 7].

Os ensaios de biocompatibilidade são de extrema importância no desenvolvimento de biomateriais para implantes, não apenas como critério que aprove ou rejeite um material ou dispositivo, mas como um conjunto de procedimentos que permite caracterizar corretamente o desempenho biológico de um material e estabelecer critérios para identificação, eliminação ou determinação de limites toleráveis de reações adversas [7]. Conforme Gibbons [6], o fato de ser compatível com órgãos ou tecidos vivos não implica que o biomaterial seja completamente inerte; pelo contrário, um grau de interação é necessário para maior eficiência do mesmo.

Segundo Lyman e Seare [4], a escolha de um biomaterial para um implante deve atentar sobre o efeito do material no corpo humano, (do nível celular até o dos sistemas); e o efeito do corpo no implante. Desta forma, pode-se ou não optar pela escolha de um determinado biomaterial, sabendo-se que o mesmo não deve apresentar reações adversas significativas aos órgãos ou tecidos adjacentes, tais como: irritações, inflamações agudas ou crônicas, infecções, dificuldades para 
cicatrizações e até mesmo efeitos da interação com produtos oriundos da biodegradação dos materiais.

Com relação ao efeito causado pelos implantes metálicos no corpo humano, destacam-se a estrutura da superfície do biomaterial, suas características mecânicas, tamanho, formato, desprendimento de partículas de desgaste e degradação; e em relação ao efeito causado pelo corpo humano no implante têm-se o estado de hidratação do meio, a intensidade de esforços ou solicitações a que o corpo humano como um todo está submetido e, consequentemente, o implante [7].

Os testes mais utilizados para se avaliar um material no tocante à sua biocompatibilidade são: citotoxicidade, genotoxicidade e hemocompatibilidade.

\subsection{Materiais Metálicos}

\subsubsection{Aços Inoxidáveis}

Os aços inoxidáveis são ligas de ferro, carbono, cromo, níquel e outros elementos químicos, como nitrogênio, manganês, molibdênio.

O ferro apresenta três fases alotrópicas no estado sólido: ferrita $(\alpha)$, austenita $(\gamma)$, e ferrita- $\delta$, que ocorrem em diferentes faixas de temperaturas: ferrita $\left(<911^{\circ} \mathrm{C}\right)$, austenita $\left(911-1392{ }^{\circ} \mathrm{C}\right)$, ferrita- $\delta\left(1392-1536{ }^{\circ} \mathrm{C}\right)$, e ferro no estado líquido $\left(>1536^{\circ} \mathrm{C}\right)[20]$. A ferrita possui estrutura cristalina cúbica de corpo centrado (CCC), a ferrita- $\delta$ tem arranjo atômico similar à ferrita, mas apresenta distâncias interatômicas maiores, por causa das temperaturas elevadas. A austenita apresenta estrutura cristalina cúbica de faces centradas (CFC) e arranjo mais compacto do que a ferrita. A transição de uma estrutura para a outra implica em variação volumétrica, que pode acarretar em tensões residuais.

Os aços inoxidáveis possuem elevada resistência à corrosão em vários meios. Esta propriedade ocorre pela formação de um filme passivo, de caráter protetor, que funciona como uma barreira entre o material e o ambiente. $O$ cromo é o principal responsável por esta proteção por formar a uma película resistente que forma em contato com o oxigênio do ar [9, 20]. 
As faixas de estabilidade das várias fases no aço são dependentes dos elementos de liga presentes nos mesmos. Um elemento de liga que é dissolvido preferencialmente em determinada fase, causa a sua estabilização, isto é, favorece a sua formação. Nos aços inoxidáveis, os elementos de liga são divididos em estabilizadores da ferrita e estabilizadores da austenita [9-11, 20].

Os principais elementos de liga estabilizadores da ferrita são: $\mathrm{Cr}, \mathrm{Mo}, \mathrm{Si}$, $\mathrm{Nb}$ e Ti; e os principais estabilizadores da austenita são: $\mathrm{C}, \mathrm{Ni}, \mathrm{Mn}, \mathrm{N}$.

Os aços inoxidáveis são classificados de acordo com a microestrutura, composição química e tratamento térmico em: ferríticos, austeníticos, martensíticos, dúplex e endurecíveis por precipitação.

\subsubsection{Aços Inoxidáveis Austeníticos}

Os aços inoxidáveis austeníticos têm teores de cromo entre 18-20\% (em massa) e de níquel ao redor de $8 \%$ (em massa). O teor de carbono é normalmente inferior a $0,08 \%$ (em massa), já os designados como "low carbon", tipo baixo carbono, possuem teor de carbono abaixo de 0,03\%. Este valor é considerado aceitável para se evitar a sensitização, que é a precipitação de carbonetos de cromo no contorno de grão, fenômeno associado à corrosão intergranular dos aços inoxidáveis.

Estes aços inoxidáveis possuem arranjo cristalino cúbico de faces centradas (CFC) devido à adição de níquel, têm alta tenacidade, elevada resistência à corrosão, não apresentam caráter magnético, sendo os mais indicados para a produção de dispositivos médicos implantáveis [5-7, 9-11, 20].

\subsubsection{Aço ABNT NBR ISO 5832-1}

Para a definição da composição química do aço inoxidável utilizado em implantes ortopédicos, devem ser respeitadas as normas da American Society for Testing and Materials (ASTM F138) e da International Organization for Standardization (ISO 5832-1), sendo esta última a mais recomendada, por exigir 
teores mais elevados (\% em massa) de elementos de liga que conferem maior resistência mecânica e eletroquímica ao metal.

Com relação à microestrutura do biomaterial metálico para aplicação em implantes ortopédicos, as normas indicam que esta deve favorecer $100 \%$ de austenita e ser isenta de ferrita delta, por esta fase ser ferromagnética. A microestrutura deve ser a mais homogênea possível, além disso, não deve possuir inclusões não metálicas (sulfetos, aluminatos, silicatos e outros óxidos), que aumentam a susceptibilidade à ocorrência de corrosão localizada e se tornam regiões com probabilidade elevada para a ocorrência de trincas, que abreviam a vida útil do dispositivo.

O tamanho de grão deve ter grau ASTM 4 (diâmetro médio: $91 \mu \mathrm{m}$ ) ou superior, isto é, diâmetros menores. Espera-se que o tamanho de grão seja homogêneo ao longo de toda a peça para que não haja prejuízo das propriedades mecânicas e de resistência à fadiga do biomaterial [10].

A composição química do biomaterial metálico lhe confere a capacidade de formar, quando em contato com o ambiente úmido e oxigenado do organismo, um óxido protetor sobre sua superfície, que proporciona resistência à corrosão.

\subsection{Tratamentos de Superfície}

O acabamento superficial dos biomateriais é de importância crucial para o desempenho de suas funções. Rugosidades e topografias distintas são, às vezes, requeridas de acordo com a geometria, projeto, tamanho do implante e local de implantação. As características do acabamento superficial influenciam vários fatores relacionados às propriedades biomecânicas, eletroquímicas e tribológicas dos biomateriais. A rugosidade é necessária para que haja melhor aderência e fixação; o acabamento mais liso e polido é desejado para a substituição de articulações do corpo humano, estas normalmente são substituídas por conjuntos contendo biomateriais metálicos e poliméricos ou, metálicos e cerâmicos, ou ainda, metálicos e compósitos.

Hong e Nagumo [21] estudaram o efeito da rugosidade superficial nos primeiros estágios de corrosão por pite no aço inoxidável AISI 301 em solução de $0,5 \mathrm{M}$ de $\mathrm{NaCl}$ e apresentaram os resultados em termos de diagramas de 
impedância e curvas de polarização. Amostras foram lixadas com diferentes granulometrias e, concluiram que o coeficiente de impedância de Warburg diminuia quando aumentava-se a numeração da lixa usada, ou seja, menos rugosa era a amostra. Este fato foi relacionado ao maior número de pites metaestáveis encontrados em superfícies mais rugosas, pois há um aumento da área efetivamente analisada.

Patrikar [22] realizou análises com o intuito de modelar e simular a rugosidade da superfície por métodos numéricos e o emprego de redes neurais. A rugosidade superficial causa vários efeitos importantes nas propriedades elétricas dos materiais, como na capacitância, condutividade eletrônica, picos no campo elétrico, entre outros. A resistência elétrica em um filme fino metálico pode aumentar devido ao espalhamento de elétrons, defeitos pontuais, presença de impurezas e mudança na orientação dos grãos; desde que a rugosidade superficial aumente, a resistência elétrica dos filmes finos também aumenta [22].

A topografia da superfície de um metal é determinada pelos processos de acabamento, o que afeta fortemente a sua resistência à corrosão. Estudos com o aço inoxidável ferrítico $21 \mathrm{Cr}$, com topografia semelhante a picos e vales, relacionaram a profundidade dos vales com regiões que favoreciam a nucleação de pites, enquanto que parâmetros como a rugosidade média não possuíam correlação direta com o comportamento frente à corrosão localizada [23].

\subsubsection{Marcação e Texturização de Implantes Ortopédicos}

De acordo com Pourbaix et al. [24], o tratamento superficial e a marcação podem influenciar na resposta óssea local, na consolidação óssea ou sua ausência, e na resistência à fadiga dos implantes. Essa resposta óssea local em implantes metálicos é afetada pela diminuição da resistência à corrosão localizada, concomitantemente ao desprendimento de partículas do próprio biomaterial e, condição da superfície; colocando em risco a biocompatibilidade, mesmo na ausência de corrosão, ou afetar a interação adequada entre os componentes do implante. Na Figura 2 é apresentado um exemplo de implante ortopédico com marcações indicadas pela seta. 


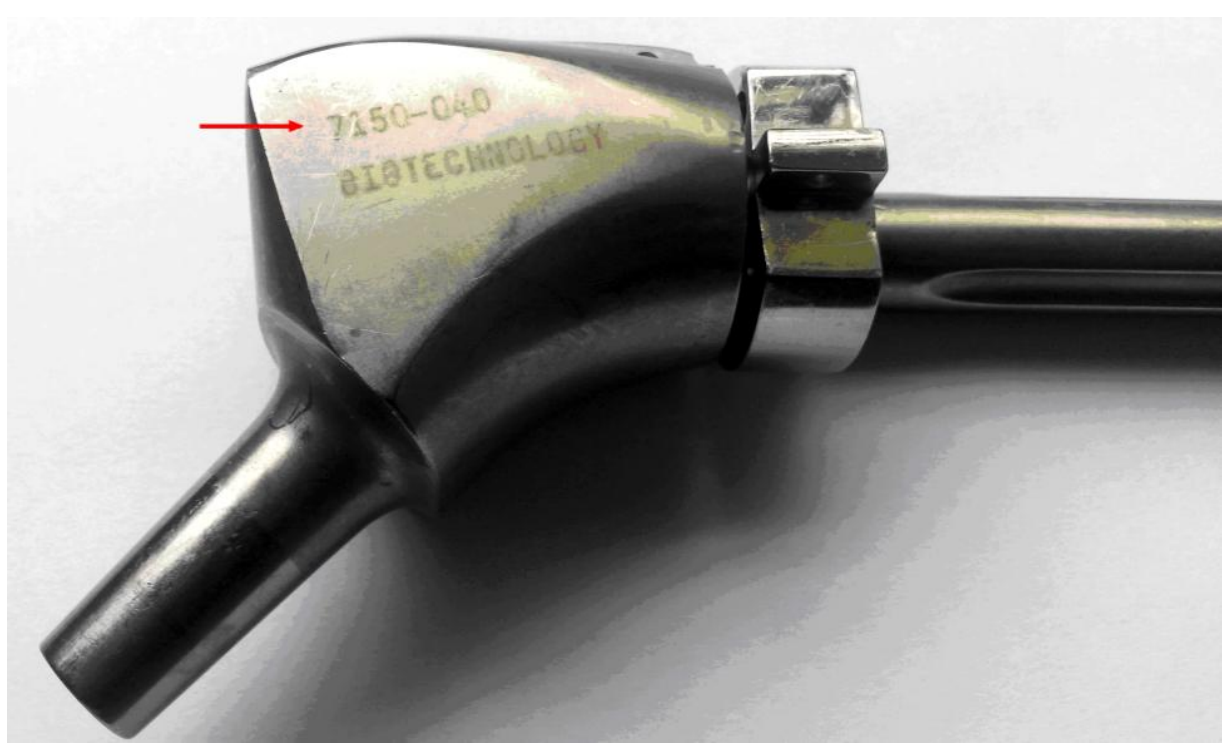

Figura 2. Marcação realizada na região da cabeça femoral de um implante ortopédico metálico. [Fonte: 0 autor].

A utilização de técnicas de marcação apropriadas e a escolha de posições mais adequadas para a marcação do implante contribuem para a diminuição de efeitos adversos, como redução das propriedades biomecânicas relacionadas à fadiga, flexão, flexo-compressão, tração e torção, ou de resistência à corrosão.

Conforme a norma ABNT NBR 12932:2010 [25], a localização da marcação em implantes deve ser indicada no projeto do implante e estar em uma região de baixa concentração de tensões e não deve cruzar as bordas de furos, escareamentos, reentrâncias, mudanças bruscas de secção ou bordas de implantes. As texturizações são tratamentos de superfície realizados com o objetivo de modificar a rugosidade topográfica dos biomateriais a fim de se obter um acabamento superficial mais áspero, que garanta maior fixação entre o implante e o tecido adjacente.

As marcações e as texturizações podem ser realizadas por várias técnicas tais como: mecânicas, químicas, jateamentos ou por feixe laser [1]. 


\subsection{Interação do Feixe Laser com a Matéria}

\subsubsection{Princípios Básicos da Tecnologia do Laser}

As transições eletrônicas radiativas são todas espontâneas, ou seja, um elétron decai de um estado de alta energia para um estado de energia inferior sem que haja uma ativação proveniente de uma fonte externa. Estes eventos de transição ocorrem de forma independente e em períodos aleatórios, produzindo uma radiação que é incoerente; isto é, as ondas de luz estão fora de fase. O laser, ao contrário, é uma fonte de luz que produz um feixe altamente coerente e praticamente monocromático. O feixe laser altamente coerente é gerado por transições eletrônicas que são iniciadas por um estímulo proveniente do meio externo [26].

A palavra laser é o acrônimo em inglês para "amplificação da luz pela emissão estimulada de radiação" (light amplification by stimulated emission of radiation) [20, 26-28].

Conceitualmente, quando um átomo possui um nível de energia $(E)$ no estado fundamental, ele pode absorver um fóton com frequência $\left(f_{0}\right)$, segundo a relação:

$$
E=h . f_{0}=h .\left(c / \lambda_{0}\right) \quad(\text { Equação } 1)
$$

onde $\mathrm{h}$ é a constante de Plank, com valor numérico : $\mathrm{h}=6,6260755 \times 10^{-34} \mathrm{~J} \cdot \mathrm{s}$ e a velocidade da luz no vácuo: $c=3,0 \times 10^{8} \mathrm{~m}^{-1} \mathrm{~s}^{-}$. O valor de frequência da luz $\left(\mathrm{f}_{0}\right)$ é inversamente proporcional ao seu comprimento de onda $\left(\lambda_{0}\right)$, de acordo com 0 tipo de laser.

Assim, ao se atingir um nível excitado de energia, depois de certo tempo, o átomo retorna ao nível em que estava anteriormente (fundamental) emitindo um fóton com a mesma frequência que a do fóton absorvido, com direção e fase aleatória. Neste caso, trata-se de uma emissão espontânea. Entretanto, o laser utiliza a emissão estimulada de átomos em níveis previamente excitados para gerar um feixe coerente composto por um grande número de fótons. Um efeito de ressonância induz cada átomo a emitir um segundo fóton com a mesma direção, fase, frequência e polarização do fóton incidente, que não se altera pelo processo. 
Em razão do primeiro e segundo fótons terem a mesma fase, eles emergem simultaneamente como um feixe coerente [26, 27].

Por ser colimado, um feixe laser pode ser deslocado por grandes distâncias, mantendo o seu paralelismo, ou seja, sem espalhamento [26].

O meio laser é o local onde ele é efetivamente gerado. O meio pode ser de estado sólido, meio líquido ou gasoso. Dentre os de estado sólido, têm-se os de barras, de discos e de fibras, dependendo da sua geometria. Os modos de operação podem ser: contínuo, modulado ou pulsado.

No funcionamento pulsado, o feixe laser é emitido sob a forma de pulsos muito curtos com picos de potência (peak power) muito elevados. Devido às interrupções do processo de bombeamento, é aplicada menos energia para o meio laser. Nas pausas entre os pulsos é armazenada muita energia para os pulsos subsequentes, o que explica a potência de pico elevada [28].

Os lasers pulsados ( $Q$-switched), utilizados quase que exclusivamente por lasers de estado sólido, são úteis em muitas aplicações nas quais os lasers de onda contínua não são muito eficazes, porque a energia de um laser pulsado é comprimida em pacotes concentrados. Esta energia concentrada em um laser pulsado é superior à proveniente de um laser de onda contínua. Na Figura 3 é apresentada uma representação esquemática da mesma quantidade de potência de saída para lasers com onda contínua e pulsada, onde no segundo caso existem picos de potência (peak power) devido à elevada concentração de energia durante cada pulso [27].

Ao se medir a saída de um laser de onda contínua, o valor medido corresponde à quantidade de energia que sai durante um determinado período de tempo. A energia é medida em joules, e o tempo em segundos. A taxa com que a energia é emitida pelo equipamento de laser, isto é, o número de joules por segundo, é a potência do laser, em watts. A frequência dos pulsos, $f$, indica a quantidade de pulsos por segundo. A potência média é calculada pelo produto da energia de um pulso pela frequência dos pulsos do laser. 

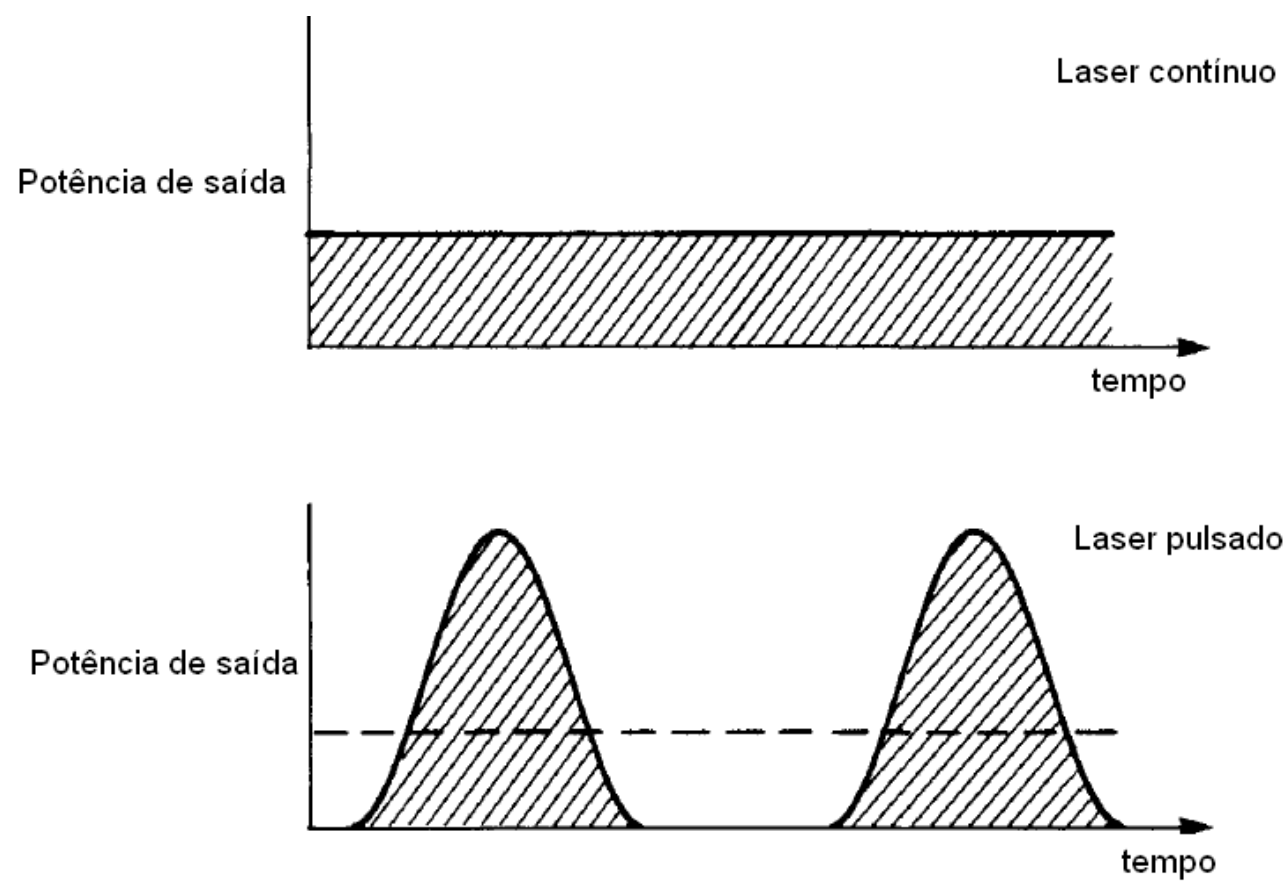

Figura 3. A energia (área sombreada) é produzida em pacotes concentrados por um laser pulsado. Como a energia é concentrada, sua potência de pico é maior do que a de um laser contínuo. Imagem adaptada da referência [27].

A potência de pico, ou "peak power", é uma medida da taxa na qual a energia sai durante o pulso, isto é, a razão da energia pelo tempo do pulso. A intensidade de cada pulso pode ser calculada por uma razão entre o peak power e área focal efetiva do pulso. A fluência do laser pode ser obtida pela razão entre a energia e a área efetiva do pulso [27].

A influência dos parâmetros do laser no processamento de materiais depende diretamente de vários parâmetros reguláveis, tais como: potência média, velocidade, frequência de pulsos e duração dos pulsos. Alterando-se um deles, por exemplo, a frequência e mantendo fixos os demais, alteram-se os valores de energia, a área efetiva do pulso, a potência, a fluência e o peak power ; o que acarreta em mudanças significativas nas superfícies dos materiais submetidos à interação com o feixe laser [28].

Existe uma grande variedade de aplicações dos lasers para uma infinidade de materiais, tais como: usinagem, ablação, têmpera, soldagem, marcação, texturização, medições de alta precisão, sistemas de comunicação e realização de procedimentos cirúrgicos [20, 26-28]. 


\subsubsection{Marcação de Aços Inoxidáveis por Feixe Laser}

Qi et al.[29] estudaram o processo de gravação em aços inoxidáveis por feixe laser. Eles utilizaram um laser tipo Q-switched de Nd:YAG e avaliaram a influência da frequência do pulso, da energia e da velocidade na qualidade da gravação produzida. Comparando-se qualitativamente a profundidade, largura e contraste gerados pela gravação, constataram que a frequência do pulso era o parâmetro que mais afetava o contraste da gravação devido à oxidação.

Analogamente, Leone et al. [30] verificaram tratar-se da frequência do pulso, o parâmetro que mais interferia no contraste obtido nas imagens digitais das superfícies submetidas às gravações. Leone et al. [30] utilizaram o mesmo tipo de laser e os mesmos parâmetros da pesquisa publicada por Qi et al. [29], o material que sofreu as marcações foi um aço inoxidável AISI 304. Eles observaram que a rugosidade e a oxidação da superfície gravada aumentavam em razão do aumento da frequência até um dado valor e, posteriormente, decresciam a partir deste.

Bizi-Bandoki et al. [31] estudaram as modificações na rugosidade e molhamento do aço inoxidável AISI 316L e da liga Ti-6Al-4V, tratados por laser com pulsos ultra-curtos. Foi utilizado um laser de titânio-safira, variando-se somente o número de pulsos. Os pesquisadores verificaram que, conforme se aumentava o número de pulsos, as características topográficas de ambos os materiais também eram alteradas, produzindo ondulações na superfície e as ligas mudavam o seu comportamento, de hidrofílicas para hidrofóbicas.

No trabalho publicado por Valette et al. [32], foi apresentado como alternativa aos métodos convencionais de marcação a laser, a técnica de marcação que utiliza um feixe laser de femtosegundos. Segundo estes autores [32], a principal vantagem de se utilizar o laser de pulsos de femtosegundos é a possibilidade de se obter maior precisão quanto à marcação e corte a laser em vários tipos de materiais, com reduzida área termicamente afetada. Neste estudo, foram utilizados os aços inoxidáveis Z30C13 (martensítico) e AISI 316L (austenítico) e as medidas eletroquímicas foram determinadas com base em curvas de polarização cíclica antes e após as marcações via laser Ti:Sa (titânio:safira), com pulsos de 150 femtossegundos, em $1 \mathrm{kHz}$ de frequência. Contrariamente ao que ocorre com laser de nanossegundos, que conduz à queda 
da passividade do óxido formado sobre os aços inoxidáveis, diminuindo a sua resistência à corrosão localizada; o método de marcação com laser de femtossegundos proporcionou um aumento na resistência à corrosão dos aços inoxidáveis estudados, devido à diminuição da energia.

No tocante às mudanças microestruturais nos materiais metálicos tratados a laser, Soriano et al. [33] avaliaram o efeito da técnica de endurecimento superficial por laser em materiais metálicos. Foi utilizado um laser de onda contínua de Nd:YAG. Após o tratamento foi obtida microestrutura martensítica e austenita retida, o que proporcionou maiores dureza e resistência ao desgaste. $\mathrm{O}$ estudo [33] foi apoiado por microscopia óptica, por microdureza Vickers ao longo da secção transversal, e por difração de raios $X$.

Um método que permite marcações rápidas e flexíveis de superfícies curvas e/ou com formatos complexos, em 2D e 3D foi estudado por Diaci et al. [34]. Eles utilizaram um laser Q-switched de nanossegundos de $\mathrm{Nd}: \mathrm{YVO}_{4}$, uma câmera digital foi acoplada ao dispositivo possibilitando por meio de software, medir as formas em 3D, de maneira rápida e precisa e, a determinação da posição da superfície que está sendo gravada.

Algumas pesquisas envolvendo gravações a laser preocupam-se com análises qualitativas de caráter visual e estético, não sendo encontradas pesquisas específicas que avaliem o efeito dos parâmetros das gravações a laser, relacionando-as com a resistência mecânica e o comportamento eletroquímico de aços inoxidáveis utilizados como biomateriais.

\subsection{Efeitos Causadores de Falhas em Implantes Ortopédicos}

\subsubsection{Fadiga}

Fadiga é uma espécie de falha que ocorre em componentes que estão sujeitos a tensões dinâmicas e oscilantes. Sob essas circunstâncias, é possível a ocorrência de uma falha em um nível de tensão consideravelmente inferior ao limite de resistência à tração ou ao limite de escoamento para uma carga estática. O termo "fadiga" é utilizado, pois este tipo de falha acontece normalmente após um longo período de tensão repetitiva ou ciclo de deformação [20]. 
A falha por fadiga é de natureza frágil, mesmo em metais dúcteis, no sentido de que existe pouca deformação plástica generalizada associada com a falha. O processo ocorre pela iniciação e propagação de trincas e, em geral, a superfície de fratura é perpendicular à direção da tensão de tração aplicada [35].

As propriedades relativas à fadiga de um material podem ser determinadas por meio da realização de ensaios, onde se avalia a amplitude de tensões $(\sigma)$ iniciando-se com um valor máximo com relação ao número de ciclos $(\mathrm{N})$, até a ruptura. Os valores obtidos são apresentados em um gráfico de tensão em função do logaritmo do número de ciclos até a ocorrência da fratura.

Para alguns metais e suas ligas, a curva $\sigma \times \mathrm{N}$ se torna uma reta horizontal para valores elevados de N; ou, existe um nível de tensões limitante, chamado de limite de resistência à fadiga, abaixo do qual a falha por fadiga não ocorre; o que para muitos aços, varia entre 35 e $60 \%$ do limite de resistência à tração. A resistência à fadiga é definida como o nível de tensões no qual a falha ocorre para certo número de ciclos $\mathrm{N}_{\mathrm{f}}$, (este chamado, também, de vida em fadiga) [20, 35].

O comportamento à fadiga dos materiais metálicos é altamente sensível a vários fatores, entre eles: o nível médio de tensão, o projeto geométrico, variáveis metalúrgicas, características da superfície e o ambiente em que estão expostos. Conforme Coffin, Jr. [35], é comum separarem-se os processos de fadiga em ar dos que ocorrem em ambientes agressivos (associados à corrosão).

Speidel [36] classificou as falhas de fadiga-corrosão em três regimes: 1) pura fadiga, onde o comportamento depende unicamente do número de ciclos em determinada tensão; 2) fadiga-corrosão, onde se pode assumir que o crescimento das trincas é dependente da combinação das tensões cíclicas e estáticas (envolvendo corrosão sob tensão) e, 3) fadiga-corrosão "real" onde as condições do ambiente isoladas não causam a extensão das trincas nas peças sob um carregamento estático.

Fraturas e desgastes decorrentes do processo de fadiga têm sido identificados como os maiores causadores de falhas em biomateriais, principalmente, em implantes que atuam no lugar dos ossos ou outros tecidos rígidos (duros), pois estão sujeitos às condições que envolvem carregamentos cíclicos graves. De acordo com Niinomi [37], as características de fadiga estão intimamente relacionadas com as microestruturas, o que nos biomateriais metálicos depende do tipo de processamento e tratamento térmico realizados. 
A resistência à fadiga de implantes também é afetada pela topografia das superfícies, estrutura e tensões residuais do material. A capacidade de resistir à fadiga pode ser determinada experimentalmente, contudo, para a avaliação ou o ensaio de implantes acabados, o componente deve ter acabamento superficial, tensões residuais, tratamentos de superfície e outras características que representem o processo pelo qual o implante é produzido. Niinomi [37] acrescenta que é necessário compreender os mecanismos de iniciação e propagação de trincas por fadiga, para se inibir a falha catastrófica de um biomaterial. Ele considera, também, que a falha catastrófica de materiais bioestruturais pode ser evitada interrompendo-se o aumento da trinca, durante o estágio de propagação estável da mesma.

A importância de se estudar a fadiga de biomateriais, em grande parte, está na abreviação da vida útil do biomaterial e na resposta adversa dos tecidos ou órgãos hospedeiros destes dispositivos médicos em relação às partículas resultantes do desgaste; o que nada mais é do que um mecanismo de defesa do organismo. Estas partículas, sub-produtos da falha por fadiga, usualmente desencadeiam alguma resposta imunológica (presença de corpo estranho) e inflamação, além de numerosa atividade bioquímica; que inclui mudanças bruscas no $\mathrm{pH}$ local, para um pH inferior a 3, por exemplo [38].

Nos estudos de Teoh [38], assume-se que essas partículas não são tóxicas; e existem três cenários: a) as células circunvizinhas tentam digerir estas partículas, dissolvendo-as com a ajuda de enzimas, absorvendo-as e eliminandoas pela corrente sanguínea e sistema linfático; b) o corpo tenta excretá-las fora do organismo; c) as fibras celulares as encapsulam a fim de mantê-las isoladas dos tecidos adjacentes.

Teoh [38] enfatiza que, para se entender as falhas por fadiga em biomateriais, torna-se essencial a compreensão da 'sub-estrutura da superfície' dos biomateriais e, como suas camadas e sub-camadas interagem com o meio fisiológico em que está inserido, como está apresentado esquematicamente, para um biomaterial metálico, na Figura 4. 


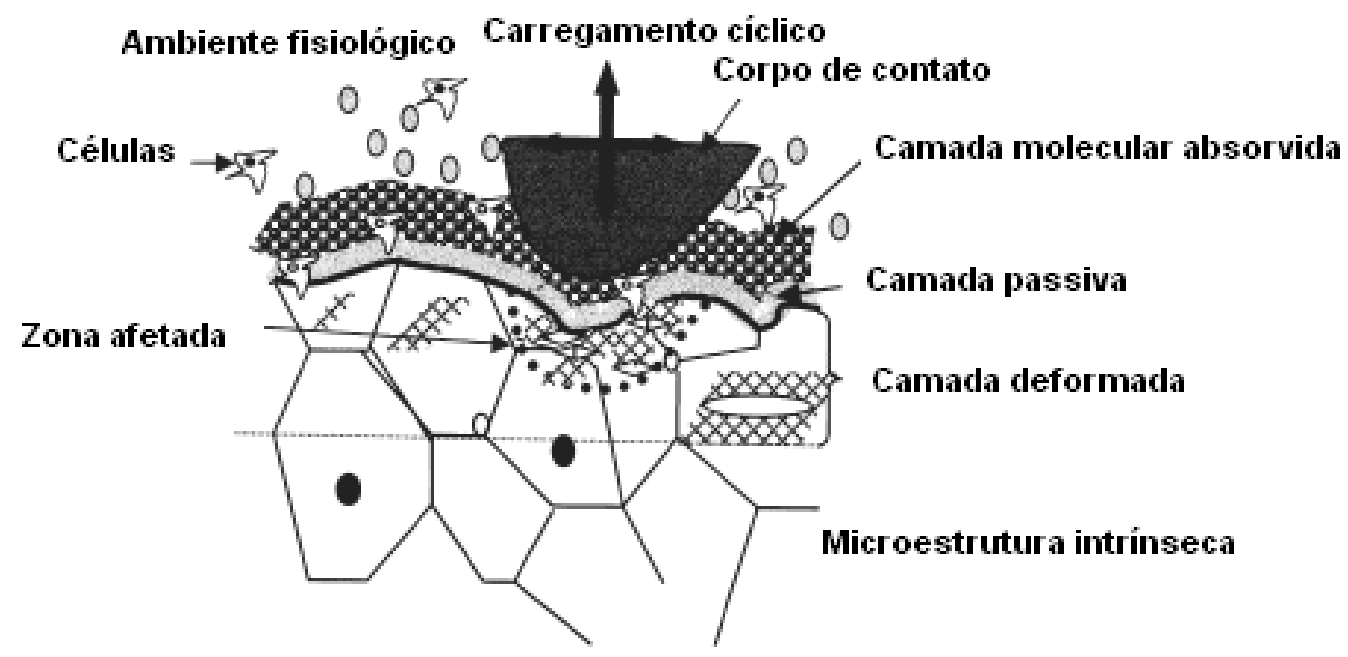

Figura 4. Ilustração da secção transversal da superfície de um biomaterial metálico deformado, mostrando as complexas interações entre a superfície do material e o meio fisiológico [38].

A resistência à fadiga de implantes metálicos tem sido pesquisada com o intuito de se estabelecer relações com a microestrutura, propriedades da superfície e de resistência à corrosão dos mesmos. Portanto é interessante notar as diferenças acarretadas pelos modos de produção dos implantes; por exemplo, o forjamento, que introduz tensões compressivas no material e induz o aumento na resistência à fadiga do material.

Na Figura 5 está apresentada a influência do processo de transformação metal-mecânica em algumas ligas metálicas amplamente utilizadas como biomateriais, na resistência à fadiga ao ar. Nota-se que o processamento posterior para um mesmo material eleva a sua resistência à fadiga, como no caso das ligas forjadas e HIP ("high isostatic pressure").

Segundo Teoh [38], os processos mecânicos e químicos em conjunto desencadeiam uma abertura e consequente iniciação de trincas, mais a inabilidade de se repassivar rapidamente ocasiona uma "quebra" eletroquímica do filme protetor (passivo), que acaba por expor estas regiões à corrosão localizada, reduzindo a vida útil do dispositivo médico implantável. 


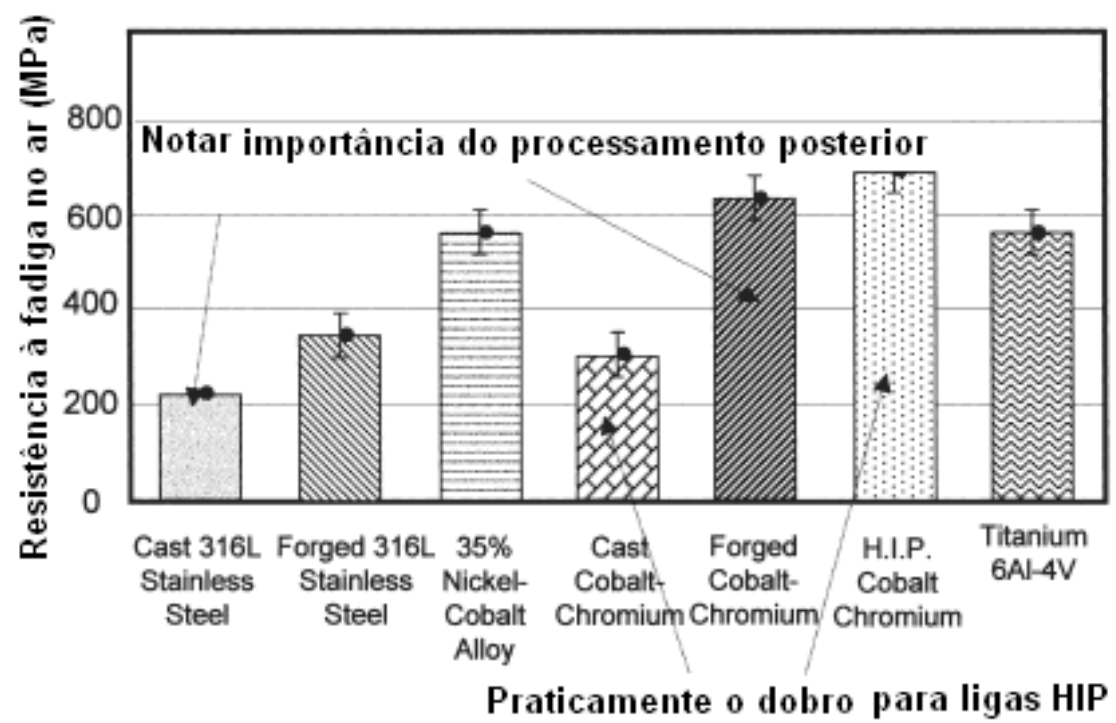

Figura 5. Resistência à fadiga de algumas das ligas metálicas mais utilizadas para implantes ortopédicos. Adaptado da referência: [38].

Giordani e outros pesquisadores [11, 12, 39, 40] estudaram o efeito da fadiga associada à corrosão dos aços ASTM F138 e ISO 5832-9, e visualizaram a influência que o meio agressivo exerce sobre os biomateriais na redução da vida em fadiga, facilitando a nucleação precoce de trincas por fadiga.

Supõe-se que o meio corrosivo facilite a formação de várias descontinuidades geométricas (pites de corrosão) nas superfícies previamente lisas de corpos de prova metálicos.

Gil et al. [41] estudaram a influência da marcação a laser em biomateriais produzidos em titânio e Ti-6Al-4V em seu comportamento mecânico e eletroquímico. Foi utilizada uma solução que simulava os fluidos corpóreos a $37^{\circ} \mathrm{C}$, e foram realizadas polarizações cíclicas e ensaios de fadiga. As amostras submetidas às marcações a laser apresentaram menores valores de resistência à corrosão e de resistência à fadiga.

Este comportamento foi relacionado, pelos pesquisadores, às mudanças microestruturais, tais como: diminuição do tamanho de grão na zona fundida e tensões residuais que favoreceriam o decréscimo da resistência à corrosão. 


\subsubsection{Desgaste}

O comportamento frente ao desgaste dos biomateriais metálicos é sensível a vários fatores, entre eles: o nível médio de tensão, o projeto geométrico, variáveis metalúrgicas, características da superfície e o ambiente em que estão expostos. A resistência ao desgaste de biomateriais tem sido pesquisada com 0 intuito de se estabelecer relações com a microestrutura, propriedades da superfície e de resistência à corrosão.

O ambiente em que os implantes ortopédicos encontram-se inseridos pode, por vezes, induzir vibrações no contato entre os componentes protéticos modulares. O desprendmento de partículas (mesmo microscópicas) contribui para a falência do implante. A presença de fluidos contendo íons cloreto inicia um fenômeno de corrosão localizada [42], que acelera o processo de desgaste. A liberação de partículas além de causar a falha do dispositivo, ainda afeta os tecidos biológicos circunvizinhos.

Os implantes projetados para substituir totalmente articulações, por exemplo a coxo-femoral, e que apresentam contato metal-metal, metal-polímero, ou metal-cerâmico devem ser fabricados com biomateriais de elevada resistência ao desgaste e à corrosão [43, 44]. Wood et al. [44] estudaram ligas fundidas de CoCrMo no tocante aos mecanismos de desgaste micro-abrasivo e comportamento eletroquímico. Foram utilizadas partículas de $\mathrm{SiC}$ e $\mathrm{Al}_{2} \mathrm{O}_{3}$ em soluções de $0,9 \% \mathrm{NaCl}$ e $25 \%$ de soro bovino, em ensaios de desgaste por esferas rotativas. Os autores relataram o efeito deletério das partículas microabrasivas na taxa e mecanismo de desgaste, principalmente, em soluções contendo proteínas.

A investigação de fenômenos relacionados ao comportamento tribológico e corrosivo é de importância crucial no estudo de biomateriais para aplicações ortopédicas, pois colabora para um melhor entendimento de fenômenos de contato entre biomateriais de mesma natureza ou de naturezas distintas [44, 45].

A falência prematura dos biomateriais usados em implantes, decorrente de desgaste em fluidos corpóreos, constitui um problema de caráter clínico e de engenharia que, em razão do avanço na utilização destes materiais, necessita ser estudado. 


\subsubsection{Corrosão}

A corrosão é a reação de um material com o ambiente em que está inserido. A corrosão é um processo que envolve tanto reações de oxidação como de redução [46].

Apesar de que os biomateriais metálicos empregados atualmente tenham suas propriedades de corrosão bem caracterizadas, alguns processos de fabricação de dispositivos podem alterar a resistência à corrosão dos implantes.

De acordo com Williams [5], o efeito da corrosão de implantes no corpo humano deve ser separado entre três tipos de corrosão: 1) baixa difusão metálica através da camada de óxido para o meio; 2) pouca corrosão observável; 3) corrosão extensiva a toda a área do implante. Nos dois primeiros casos há alguma interação com os tecidos adjacentes ao implante, o que geralmente não implica em efeitos clínicos significativos. O efeito do ataque localizado para o material é mais grave quanto à resistência mecânica, podendo levar a falhas por fraturas; já no terceiro caso há influência direta no paciente.

\subsection{Mecanismos de Corrosão}

\subsubsection{Corrosão por Pite}

Vários metais e ligas apresentam uma fina película que fornece proteção contra a corrosão. Esta é formada pela reação da superfície do metal com o meio ambiente e é responsável pelo fenômeno da passivação. No caso de aços inoxidáveis, cromo e níquel são usados como elementos de liga, uma vez que são facilmente passivados. Em teores de cromo entre 12\% e 18\% (em peso), as propriedades do Cr são incorporadas ao aço e o valor do potencial de passivação varia daquele típico do ferro para aproximadamente o do cromo, aumentando a resistência à corrosão localizada [20].

A corrosão por pite é um ataque localizado, na grande maioria das vezes, sobre uma superfície com óxido naturalmente formado. Um pite é iniciado pela 
adsorção de ânions ativadores, particularmente, íons cloreto. Quando o potencial de pite é atingido, a força do campo elétrico nas partes mais finas do filme é tão alta que os íons cloreto podem penetrar no filme, iniciando a dissolução localizada do filme de óxido. Assim, tão logo um pite tenha se formado, este continua a crescer autocataliticamente [20].

O mecanismo de corrosão por pite se dá por nucleação e crescimento do mesmo, o qual cria condições para a sua propagação, que são: o enriquecimento de íons cloreto no pite, geração de uma solução ácida dentro do pite; pela hidrólise de íons metálicos; alta condutividade da solução de sal; limitação do suprimento de oxigênio e; na parte externa do pite, a formação de uma camada de hidrato, contra-atacando a diluição da solução do pite por difusão e convecção.

\subsubsection{Características do Filme Passivo em Aços Inoxidáveis}

Os filmes passivos são formados por uma camada interna de óxido e uma camada externa de hidróxido ou oxi-hidróxido, (modelo de dupla camada). A camada externa age como um local de troca, devido aos íons de valência, já a camada mais interna atua como uma barreira impedindo o ataque corrosivo.

Segundo Marcus [47], a composição química, valência, espessura, cristalinidade, rugosidade e presença de defeitos influenciam o crescimento, estabilidade e quebra de camadas finas do filme passivo.

Estudos acerca de estruturas dos filmes de óxidos formados sobre aços inoxidáveis em solução tampão de borato concluíram que estas são formadas por óxidos, espinélios, hidróxidos e possuem a superfície parcialmente hidratada [48]. Com a utilização de técnicas de análise por Espectroscopia de Elétrons Auger (AES) e Microscopia de Força Atômica (AFM), descreveram este tipo de óxido como sendo composto por uma região interna rica em óxido de cromo $\left(\mathrm{Cr}_{2} \mathrm{O}_{3}\right)$, situada próximo ao substrato metálico e, uma região externa, rica em óxido de ferro $\left(\mathrm{Fe}_{2} \mathrm{O}_{3}\right)$ e hidróxido de ferro, estando situada na região da interface do filme com a solução, confirmando a característica dúplex do filme passivo [48].

Castle e Clayton [49] publicaram um dos primeiros trabalhos utilizando a técnica de espectroscopia de fotoelétrons excitados por raios $\mathrm{X}$ (XPS), fornecendo 
informações da região de interface. Eles utilizaram um aço inoxidável austenítico com $18 \%$ de cromo e $8 \%$ de níquel e, repassivando-se em água destilada, à temperatura ambiente; observou-se o caráter dúplex da camada passiva e foi possível determinar que a região mais interna da camada era enriquecida em cromo e, a mais externa em íons hidroxila.

\subsubsection{Propriedades Eletrônicas do Filme Passivo em Aços Inoxidáveis}

O filme passivo apresenta o comportamento de um óxido semicondutor, portanto suas propriedades podem ser avaliadas por meio de suas estruturas eletrônicas. O movimento eletrônico em suas bandas de energia determina a sua condutividade. As bandas de energia são divididas em: bandas de valência, que é o nível de energia mais alto ocupado por elétrons e, banda de condução, que é o nível de energia mais baixo desocupado. Os materiais metálicos apresentam a banda de condução seguida da banda de valência; desta forma, os elétrons podem ocupar a banda de condução, por isso são conhecidos como materiais condutores [20]. Os materiais que possuem uma diferença de energia entre a banda de valência e a banda de condução são conhecidos como semicondutores e/ou isolantes.

O "band gap", nome dado a esta diferença de energia é grande (superior a $3 \mathrm{eV}$ ) nos isolantes e, para os semicondutores, um valor intermediário (da ordem de zero a $3 \mathrm{eV}$ ), possibilitando o deslocamento de elétrons para as bandas de mais baixas energias desocupadas.

Um elétron excitado migra de um nível de energia para outro, gerando uma vacância ou lacuna, que é carregada positivamente. Estas podem ser movidas pelo espaço pela ocupação das vacâncias por elétrons.

Os óxidos semicondutores podem ser classificados como extrínsecos, isto é, dopados e, intrínsecos, ou seja, não dopados [20]. Os semicondutores extrínsecos podem ser do tipo-p (cargas positivas) ou do tipo-n (cargas negativas), quando o transporte de carga é realizado, respectivamente, por lacunas ou elétrons.

Vários autores [50-54] correlacionaram o comportamento semicondutor de filmes passivos em aços inoxidáveis com a resistência à corrosão. 
O modelo de camada dupla de filmes formados sobre aços inoxidáveis austeníticos [48] propõe o comportamento de um semicondutor tipo-n na camada externa, ou seja, próxima à solução e o comportamento de um semicondutor tipop na camada mais interna, rica em óxido de cromo, próxima ao substrato. 0 processo de difusão através do filme passivo é apresentado na Figura 6.

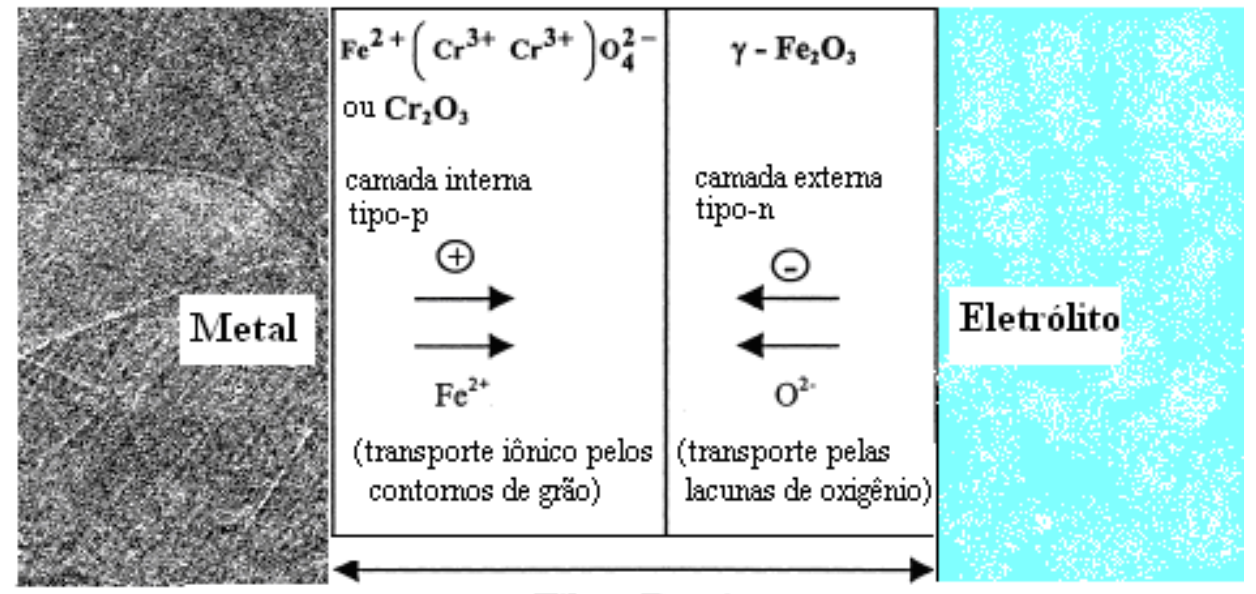

Filme Passivo

Figura 6. Representação esquemática do processo de difusão através da dupla camada do filme passivante. (Figura adaptada da referência [1]).

A abordagem de Mott-Schottky é utilizada para se estudar as propriedades eletrônicas dos filmes passivos; por meio de medidas de capacitância, utilizandose espectroscopia de impedância eletroquímica, em uma frequência específica. Os resultados deste método são apresentados em gráficos de medidas do inverso do quadrado das capacitâncias em função do potencial aplicado. As inclinações dos gráficos de Mott-Schottky são associadas com os semicondutores presentes nos óxidos, ou seja, inclinação positiva relacionada a um semicondutor tipo-n e, inclinação negativa relacionada a um semicondutor tipo-p. A equação (2) é a expressão de Mott-Schottky, usada para descrever a interface filme passivoeletrólito para um semicondutor tipo-p.

$$
\frac{1}{C^{2}}=\frac{1}{C_{H}^{2}}+\frac{2}{\varepsilon \varepsilon_{o} q N q}\left(-E+E b p+\frac{k T}{e}\right)
$$


Na equação (2) C é a capacitância da interface filme passivo-eletrólito, $\mathrm{C}_{\mathrm{H}}$ é a capacitância da camada de Helmholtz, E é o potencial aplicado, $\varepsilon$ é a constante dielétrica da película passiva, $\varepsilon_{0}$ é a permissividade do vácuo, $\mathrm{N}_{\mathrm{q}}$ é a densidade de doadores ou aceitadores para a dopagem de um semicondutor do tipo-n ou do tipo-p, respectivamente, q é a carga elementar, $k$ é a constante de Boltzmann, $T$ é a temperatura absoluta e $E_{b p}$ é o potencial de banda plana. $O$ potencial de banda plana, onde não existe excesso de cargas em um semicondutor, pode ser obtido, no gráfico, pela extrapolação de 1/C² para zero. A concentração de dopantes $\mathrm{N}_{\mathrm{q}}$ é obtida pelas inclinações das curvas [50 - 54].

A possibilidade de transferência de cargas em um semicondutor depende da existência de regiões de depleção ou de acumulação. A região de depleção é caracterizada por sua deficiência de elétrons e ocorre em potenciais positivos a partir do potencial de banda plana $\left(E_{b p}\right)$ para um semicondutor tipo-n e em potenciais negativos a partir de $\left(E_{b p}\right)$ para um semicondutor tipo-p. A região de acumulação, caracterizada por um excesso de elétrons, ocorre em potenciais mais negativos a partir de $\left(E_{b p}\right)$ para semicondutores tipo-n e mais positivos a partir de $\left(E_{b p}\right)$ para semicondutores do tipo-p. As representações dos gráficos de Mott-Schottky sempre se dão nas formas das regiões de depleção [50 - 54].

De acordo com Hakiki et al. [53], a presença de inclinações em sentidos opostos nos gráficos de $1 / C^{2}$ versus $E$, mostra que, em modo contrastante com 0 modelo de heterojunção clássica, as regiões de carga espacial formadas sobre o óxido se comportam de acordo com o potencial como regiões de acumulação ou de depleção. Assim, o óxido protetor age como uma barreira Schottky antes e após o potencial de banda plana. Eles propuseram um modelo esquemático, que está apresentado na Figura 7, para representar a estrutura eletrônica dos óxidos formados em aços inoxidáveis e em ligas de Fe-Cr. Neste esquema, o mesmo valor de "band-gap" é apresentado para os óxidos de cromo e de ferro, onde segundo referências utilizadas pelos autores e resultados obtidos, confirmaram, que o "band-gap" para o óxido de ferro apresenta valor aproximadamente igual a $2 \mathrm{eV}$, mas para o óxido de cromo, este não é bem estabelecido. O intuito deste modelo é mostrar que o óxido de cromo age como uma barreira Schottky numa faixa ou extensão de potencial onde o óxido de ferro se comporta como um contato ôhmico (condutor) e vice-versa. 


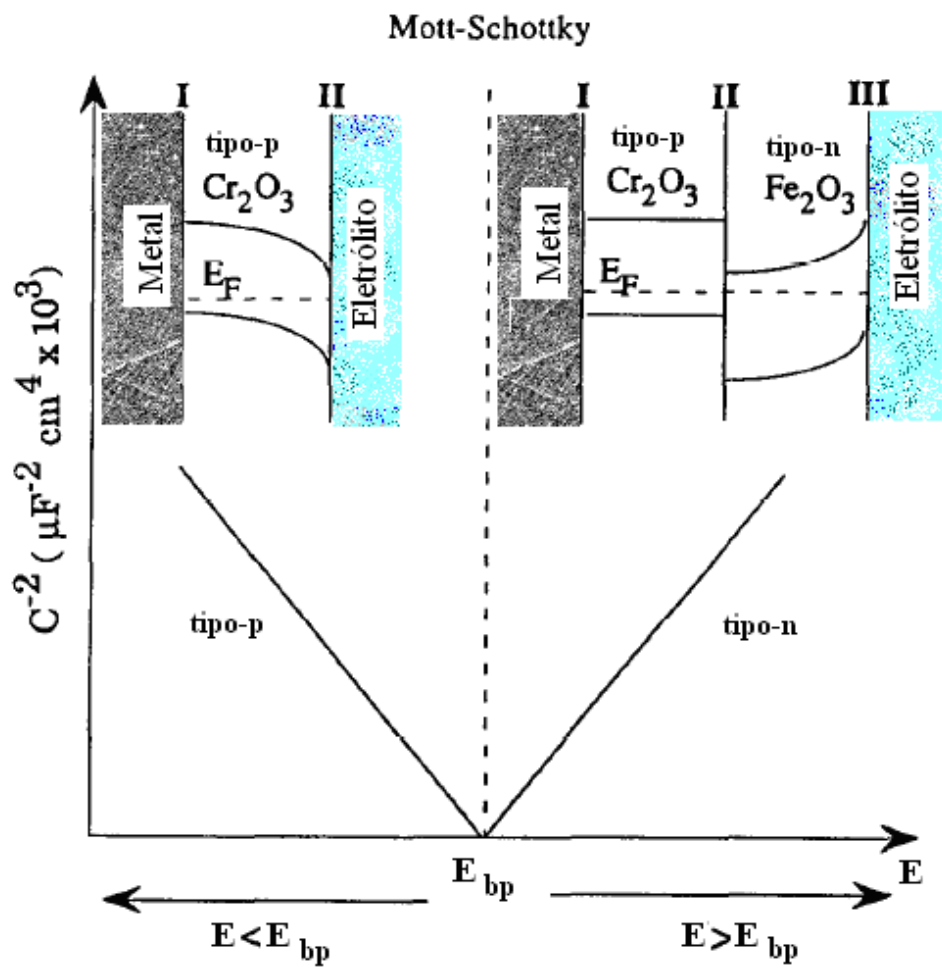

Figura 7. Representação esquemática da abordagem de Mott-Schottky para a estrutura eletrônica dos óxidos formados em aços inoxidáveis e em ligas de $\mathrm{Fe}-\mathrm{Cr}$; onde $\mathrm{E}_{\mathrm{F}}$ corresponde ao nível de Energia de Fermi e $\mathrm{E}_{\mathrm{bp}}$ ao potencial de banda plana. Adaptado da referência: [1].

Montemor et al. [55] avaliaram a composição química e a estrutura eletrônica de filmes passivos formados sobre o aço inoxidável $316 \mathrm{~L}$ e ligas de níquel (Alloy 600 e Alloy 690), em ambientes aquosos a alta temperatura. A estrutura eletrônica do óxido foi analisada pela abordagem de Mott-Schottky e a composição química, por espectroscopia de elétrons Auger (AES).

O filme passivo foi formado sobre estas ligas em solução de $\mathrm{NaOH}$ e $\mathrm{H}_{2} \mathrm{SO}_{4}$ com pH 8 e pH10. Os resultados extraídos dos gráficos de Mott-Schottky apresentaram o comportamento de um semicondutor tipo-p associado à camada mais interna (região mais rica em cromo) e, de um semicondutor tipo-n associado à camada mais externa do óxido, composta por óxidos de ferro.

Toor [56] utilizou a abordagem de Mott-Schottky para analisar o filme passivo em aços inoxidáveis contendo silício como elemento de liga, o que eleva a sua resistência à corrosão por pite. Baseado em análises de espectroscopia de elétrons Auger (AES), garante-se que a parte mais interna do filme passivo é composta por $\mathrm{Cr}_{2} \mathrm{O}_{3}$ e a mais externa por $\mathrm{SiO}_{2}$. Para o cálculo do número de defeitos, foi analisado o filme formado por nove horas, à temperatura ambiente $e$ 
em solução tamponada de borato de $\mathrm{pH} 8,5$, à $0,4 \mathrm{~V}_{\mathrm{ECS}}$ e $0,8 \mathrm{~V}_{\mathrm{ECS}}$. A frequência utilizada foi de $1 \mathrm{kHz}$.

Segundo o autor, o número de defeitos $\mathrm{N}_{\mathrm{D}}$ (doadores) e $\mathrm{N}_{\mathrm{A}}$ (aceitadores ou recebedores) é inversamente proporcional às inclinações das curvas que representam os semicondutores tipo-n e tipo-p, respectivamente [56].

Costuma-se desconsiderar a capacitância da camada de Helmholtz $\left(\mathrm{C}_{\mathrm{H}}\right)$, no cálculo de número de defeitos, utilizando-se as equações: (3) para um semicondutor tipo-n e, (4) para um semicondutor tipo-p.

$$
\begin{aligned}
\frac{1}{C^{2}} & =\frac{2}{\varepsilon \varepsilon_{0} e N_{D}}\left(E-E_{\boldsymbol{b p}}-\frac{k T}{e}\right) \\
\frac{1}{C^{2}} & =-\frac{2}{\varepsilon \varepsilon_{0} e N_{A}}\left(E-E_{\boldsymbol{b p}}+\frac{k T}{e}\right)
\end{aligned}
$$

(Equação 4)

A região onde é estabelecida uma transição entre os defeitos eletrônicos dos dois tipos de semicondutividade $n$ e $p$ e representada pelo potencial de banda plana $\left(E_{b p}\right)$. A partir do potencial de banda plana, uma inclinação positiva está relacionada a um semicondutor tipo-n e, uma inclinação negativa, com um semicondutor tipo-p.

\subsubsection{Espectroscopia de Impedância Eletroquímica (EIE) com Modelamento por Circuitos Elétricos Equivalentes (CEE)}

Os resultados obtidos empregando-se a técnica de espectroscopia de impedância eletroquímica (EIE) são utilizados para se representar as características físicas e elétricas da camada passiva. Estes são modelados e interpretados por circuitos elétricos equivalentes (CEE). Os modelos de circuitos elétricos equivalentes comumente utilizados e descritos na literatura [60], se valem de uma combinação de capacitores, resistores, e elementos de fase constante (CPEs) arranjados em série e/ou em paralelo. 
Conforme Bonora et al. [60], o circuito deve ser representado da forma mais simples possível, ou seja, deve conter o menor número de componentes possíveis dentro de um limite de tolerância (erro), isto é, se mesmo ao se retirar um elemento do sistema a condição previamente definida prevalecer, o circuito deve ser simplificado. Outra condição referida pelo autor é que cada elemento do circuito elétrico deve possuir um significado físico claramente associado às propriedades que podem gerar este tipo de resposta elétrica.

\subsubsection{Técnica Eletroquímica de Varredura com Eletrodo Vibrante - SVET}

Algumas vezes os equipamentos e as técnicas clássicas disponíveis tornam-se incapazes de fornecer as respostas requeridas frente à complexidade dos materiais a serem analisados, seja pela qualidade do acabamento superficial, diferentes formatos e dimensões, ou pelo que se deseja investigar [61 - 65].

As técnicas localizadas proporcionam alta resolução por possuírem sistema de captura de imagem acoplado aos aparatos eletroquímicos. Os mais conhecidos são o microscópio eletroquímico de varredura (SECM) e o microscópio de varredura de tunelamento (STM). Entre parênteses está a sigla em inglês, que é utilizada para se referir tanto ao equipamento quanto à técnica.

Uma técnica que vem aumentando o seu campo de atuação é a chamada Técnica de Varredura com Eletrodo Vibrante, cuja sigla em inglês é SVET; e também foi utilizada neste trabalho a fim de apoiar os dados obtidos pelas técnicas clássicas e possibilitar uma nova forma de obter e representar resultados, por se tratar de uma técnica eletroquímica localizada [66-68].

Os ensaios podem ser realizados em células com micro-eletrodos, ultramicro-eletrodos ou até com nano-eletrodos, nas mais diversas condições: tamanhos de células, períodos de ensaio, meios químicos e metodologias [66-69]. 


\subsection{Biomecânica do Movimento Humano}

A biomecânica é uma área que vem se consolidando ao longo dos últimos anos, sua característica multidisciplinar promove uma grande interface com diversas áreas do conhecimento, dentre elas a Engenharia, a Medicina, a Educação Física, a Fisioterapia e a Terapia Ocupacional e, dessa interação podese resultar em melhores intervenções nas diversas disfunções esqueléticas e até mesmo neurológicas.

O conhecimento dos métodos de investigação característicos da biomecânica é fundamental para que se implementem ferramentas que viabilizem a análise do movimento humano normal e patológico, e a partir daí, direcionar para os objetivos da área dos biomateriais. O aprimoramento dos conceitos biomecânicos é necessário para desenvolver projetos de pesquisa na área músculo-esquelética, principalmente no que concerne aos biomateriais utilizados em implantes para as instabilidades articulares no joelho, quadril, ombro, tornozelo, cotovelo e punho.

\subsubsection{Fatores que Acarretam no Uso de Biomateriais}

O tecido ósseo sofre remodelamento em resposta às forças internas e externas. O remodelamento ósseo é composto pela reabsorção e deposição de material ósseo. O que constitui ser altamente adaptável e também sensível ao desuso, tendo uma propriedade de auto-reparação. Sendo que as alterações em suas propriedades ocorrem em resposta à demanda mecânica. As fraturas traumáticas são as lesões ósseas mais comuns, nas quais a intensidade/carga aplicada é alta e o volume baixo, já as fraturas por fadiga consistem numa carga de baixa magnitude e uma alta frequência de aplicação da mesma.

Artrites são inflamações articulares associadas a dores e edemas, sendo altamente relacionadas ao envelhecimento e ao desgaste [70]. A osteoartrite é a forma mais comum de artrite e representa o desgaste inicial da cartilagem e posterior dilaceração, expondo a superfície óssea ao contato direto. Ocorre devido ao alto grau de tensão sofrido pela articulação e ao enfraquecimento muscular. Os músculos apresentam funções importantes além da produção de 
movimento, sendo estas a atenuação das cargas externas aplicadas ao aparelho locomotor e a manutenção da postura e estabilização das articulações [70].

A lesão ocasionada é diretamente proporcional à magnitude da sobrecarga, podendo gerar de um dano estrutural leve à ruptura grave das fibras. As contusões são resultantes de forças compressivas ou traumas, consistindo em hematomas entre as fibras musculares. Caso as contusões e os danos ao tecido biológico sejam graves, há a necessidade de intervenções cirúrgicas e utilização de biomateriais de uso temporário, para restituição, ou até mesmo permanentes, para substituição do tecido biológico.

O conhecimento do movimento das articulações é essencial para o desenvolvimento das próteses para restaurar ou reparar funções; quantificar o desgaste, estabilidade e degeneração e, determinação de diagnósticos e tratamentos cirúrgicos [7]. De modo geral, a análise cinemática do movimento humano (marcha) pode ser classificada em duas categorias distintas: movimento total dos segmentos dos membros do corpo interconectados por articulações [6] ou, análise detalhada do movimento da superfície das articulações [70 - 71].

\subsubsection{Substituição de Articulações}

A habilidade de substituir as articulações danificadas vem trazendo maior conforto a milhões de pacientes em todo o mundo, que de outra forma estariam severamente limitados desde para a prática esportiva como até em suas funções mais básicas (atividades cotidianas) [71]. Uma condição que causa a degeneração das articulações é a osteoartrite, e que provoca no paciente a necessidade de substituição total da articulação.

A degeneração da articulação é o estágio final de um processo de destruição da cartilagem articular, que resulta em dor, perda de movimento e, ocasionalmente, deformação angular permanente das extremidades do corpo humano [70]. Diferentemente dos ossos, as cartilagens têm uma capacidade de reparação muito limitada; de modo que quando expostas a um dano mecânico, químico ou metabólico elevado, a perda é de caráter permanente e progressivo.

Um implante de substituição total de articulação é de caráter permanente, diferente daquele usado para se tratar uma fratura. A quantidade de osso e 
cartilagem retirada durante o procedimento cirúrgico torna este processo irreversível. O projeto de um implante para articulação deve se basear nas características cinemáticas e dinâmicas das tensões que incidem sobre esta [71].

\subsubsection{Ensaios Biomecânicos de Biomateriais}

Cristofolini et al. [72] avaliaram a biomecânica do quadril por ensaios in vitro de resistência à fadiga de implantes para substituição total de quadril empregando a técnica de cimentação secundária. Descontinuidades criadas no intra-operatório no manto de cimento como: porosidades, capacidade de carga deficiente causada pelo posicionamento excêntrico da haste, e imperfeições devido à união implante / cimento insuficiente, influenciaram os resultados de componentes femorais altamente solicitados mecanicamente.

Foi desenvolvido um método com a haste a ser inserida no fêmur antes da injeção de cimento secundário e drenagem da cavidade medular através do componente femoral. A técnica de cimentação secundária visa permitir condições otimizadas e normalizadas para a implantação de uma haste de quadril cimentada, independentemente da habilidade do cirurgião, assim como minimizar o risco de complicações intra ou pós-operatórias [72]. Para obter estabilidade suficiente do implante, é necessário obter a "integralização" do cimento ósseo com o osso, o que pode ser conseguido pela pressurização do cimento ósseo.

O primeiro mecanismo de falha do manto de cimento in vivo é a fadiga. Eventos associados à falha incluem micro-movimentos da haste e trincas que rompem o manto de cimento. Estes pesquisadores testaram pré clinicamente a injeção de cimento na haste do implante sob as condições mais graves (correspondente aos pacientes mais ativos) [72].

Os pesquisadores [72] realizaram cortes que permitiram a inspeção da interface haste-cimento e o exame das regiões mais importantes: as partes proximais e distais, em secção transversal. Trincas macroscópicas eram visíveis na superfície interior do cimento, principalmente distal, com um padrão consistente. $\mathrm{O}$ primeiro indicador de danos por fadiga foi o número de fissuras por unidade de volume de cimento. Um indicador mais confiável da extensão do dano por fadiga é a extensão das fissuras. Mais danos foram gerados na parte medial. 
Ensaios aplicando técnicas da biomecânica in vivo confirmam que a marcha geralmente apresenta uma excelente melhoria após a substituição total do joelho. No entanto, anormalidades cinéticas e cinemáticas podem persistir mesmo após períodos longos de implantação e implicar em falhas no implante.

Benedetti et al. [73] ressaltaram que a atividade muscular de membros inferiores não foi suficientemente estudada no passado diretamente por meio de eletromiografia (EMG), portanto o objetivo deste estudo foi avaliar alterações das funções residuais musculares após a cirurgia de substituição total do joelho, com relação à cinemática e cinética da marcha. EMG do tronco e músculos dos membros inferiores foi registrado e elaborado através de um detector estatístico.

O comportamento muscular durante as atividades diárias fornece indicações acerca da integração da biomecânica do implante dentro do sistema músculo-esquelético. Esta informação é de relevância para melhorar o projeto do implante, programas de reabilitação e desenvolvimento motor do joelho. Um programa de reeducação proprioceptiva simplificado foi seguido, primeiro através de cadeia cinética aberta, em seguida, por meio de exercícios de cadeia cinética fechada na posição sentada e, finalmente, em pé [73].

Os indivíduos foram submetidos a períodos de duas semanas de reabilitação, com exercícios para manter a amplitude de movimento, para fortalecer quadríceps e isquiotibiais e para otimizar a capacidade de andar. A análise da marcha foi realizada no final de cada período de reabilitação, sendo que cada paciente utilizou os mesmos calçados durante a análise da marcha e as sessões de reabilitação [73].

O estudo de eletromiografia permitiu esclarecer irregularidades de ativação muscular durante a marcha em pacientes com substituição total de joelho (TKR total knee replacement); e a contração muscular prolongada esteve associada ao padrão de rigidez do joelho durante a fase de duplo apoio [73].

Estes estudos são importantes para o projeto do implante. Conhecendo-se a biomecânica dos biomateriais e suas propriedades tribológicas e metalúrgicas, há a possibilidade de se confeccionar implantes e próteses personalizadas, atendendo necessidades específicas. 


\section{MATERIAIS E MÉTODOS}

\subsection{Material}

O material utilizado neste trabalho consistiu em amostras do aço inoxidável austenítico ABNT NBR ISO 5832-1, no formato de chapas e barras laminadas. As chapas de $3 \mathrm{~mm}$ de espessura foram utilizadas para a confecção de corpos-deprova de fadiga e de tração. As barras de secção circular de $15 \mathrm{~mm}$ foram utilizadas para os corpos-de-prova dos demais ensaios, no formato de cilindros com as dimensões: $10 \mathrm{~mm}$ de altura $\times 15 \mathrm{~mm}$ de diâmetro. A composição química normatizada, obtida pela técnica de espectroscopia de emissão óptica, está apresentada na Tabela 1. Para fins de comparação, também foi realizada análise da composição química utilizando-se o método de espectroscopia de fluorescência de raios $X$, que está apresentada na seção de resultados. Os processos subsequentes consistiram em usinagem, desbaste, lixamento e polimento com pasta de diamante de até $1 \mu \mathrm{m}$. Os materiais (chapas e barras) foram respectivamente, fornecidos pelas empresas, Hexagon Brasil - Implantes e Instrumentos Ortopédicos e pela Villares Metals.

Tabela 1. Elementos químicos presentes na amostra do aço inoxidável ABNT NBR ISO 5832-1, obtida por espectroscopia de emissão óptica.

\begin{tabular}{l|c|c|c|c|c|c|c|c|c}
\hline Elementos & $\mathrm{C}$ & $\mathrm{Si}$ & $\mathrm{Mn}$ & $\mathrm{P}$ & $\mathrm{S}$ & $\mathrm{Cr}$ & $\mathrm{Mo}$ & $\mathrm{Ni}$ & $\mathrm{Fe}$ \\
\hline$\%$ massa & 0,023 & 0,378 & 2,09 & 0,026 & 0,0003 & 18,32 & 2,59 & 14,33 & Bal. \\
\hline
\end{tabular}

\subsection{Tratamentos Superficiais}

O termo 'amostra' refere-se aos conjuntos de espécimes que receberam marcações e texturizações pela técnica de feixe laser. Para efeito de comparação também foram analisadas amostras do referido aço sem tratamento (denominadas por: controle). O processo de marcação consistiu na gravação do algarismo 8 (oito), de modo a cobrir a maior área superficial possível, deixando livres de marcações as bordas das faces dos espécimes, a fim de possibilitar a análise da área adjacente à marcação. A marcação é muito utilizada para fins de identificação e/ou rastreabilidade do implante possibilitando a análise das 
condições do dispositivo médico implantável, após certo período de uso (anos) ou, em decorrência de fratura prematura.

As texturizações consistiram no preenchimento total de uma das faces dos espécimes por meio da geração de linhas paralelas justapostas, com os mesmos parâmetros de laser utilizados nas marcações. A finalidade das texturizações é a de alterar a superfície e melhorar o regime de aderência do biomaterial.

O equipamento utilizado foi uma máquina modelo Trumark 5050, gentilmente cedida pela TRUMPF, de laser de fibra óptica dopado com itérbio (Yb), pulsado, de comprimento de onda de $1062 \pm 3 \mathrm{~nm}$, com lente de $f=163 \mathrm{~mm}$, área de gravação de $120 \mathrm{~mm}$ x $120 \mathrm{~mm}$, velocidade de $200 \mathrm{~mm} . \mathrm{s}^{-1}$, potência média de $50 \mathrm{~W}$ e $10 \mathrm{~mm}$ de desfocagem.

Inicialmente foram realizadas 14 marcações com diferentes frequências de pulso, dentro da faixa de frequências comumente utilizadas para marcações em aços inoxidáveis com este equipamento. Este número foi reduzido para $7 \mathrm{e}$, dentre estas condições, foram selecionadas 4 , com base em inspeção visual e atributos de coloração, maior contraste e nitidez das gravações. Desta forma, foram realizadas marcações e texturizações em 4 condições diferentes. Os parâmetros que foram variados estão apresentados na Tabela 2.

Tabela 2. Parâmetros do laser utilizados para as marcações e texturizações.

\begin{tabular}{c|c|c|c|c}
\hline Parâmetros/Amostras & $\mathbf{1}$ & $\mathbf{2}$ & $\mathbf{3}$ & $\mathbf{4}$ \\
\hline Frequência [kHz] & 80 & 188 & 296 & 350 \\
\hline Duração do pulso [ns] & 167 & 40 & 23 & 20 \\
\hline
\end{tabular}

\subsection{Análises Microestruturais}

\subsubsection{Microscopia Óptica (MO)}

As análises por microscopia óptica foram realizadas em um microscópio óptico da marca Olympus, disponível no laboratório de metalografia do Centro de Ciência e Tecnologia de Materiais (CCTM) do IPEN. Os espécimes foram observados nas condições: como recebida e após os tratamentos de marcação e 
texturização por feixe laser, sem ataque metalográfico e com ataque. Também foram obtidas imagens das superfícies antes e depois dos ensaios eletroquímicos.

Os ataques metalográficos utilizados foram por imersão em água régia e, ataque eletrolítico em solução aquosa de ácido oxálico, 10\% em volume, durante um minuto (procedimento 13b da norma ASTM E407-99).

Obtiveram-se imagens tanto de topo, quanto de vista lateral (amostras cortadas e embutidas em resina epóxi).

A microscopia óptica também foi utilizada para se determinar algumas dimensões das amostras tratadas a laser, tais como: tamanho de grão, comprimento e largura das marcações.

\subsubsection{Microscopia Eletrônica de Varredura (MEV)}

Um microscópio eletrônico de varredura (MEV) Philips XL30 com microssonda EDAX para análise espectrométrica de raios $\mathrm{X}$, do Departamento de Engenharia Metalúrgica e de Materiais da Escola Politécnica da Universidade de São Paulo (PMT-EPUSP) foi utilizado para se observar a microestrutura das amostras deste biomaterial, e determinar distribuição de tamanho de grão por área nas amostras padrão (como recebida) e tratada por feixe laser.

Utilizou-se um microscópio eletrônico de varredura (MEV) de baixo vácuo com filamento de tungstênio e aproximação máxima de 10.000 vezes, marca: Hitachi, modelo: TM3000, com software para topográficos, 3D Viewer para se obter imagens das superfícies das amostras antes e após os ensaios eletroquímicos, com e sem ataque.

\subsubsection{Microscopia de Alta Resolução (Field Emission Gun)-(SEM-FEG)}

Para se obter melhor resolução de imagens e alta confiabilidade na análise da distribuição de elementos químicos nas superfícies tratadas por feixe laser, foi utilizado um microscópio eletrônico de varredura (SEM-FEG) FEI - INSPECT F50, com canhão de emissão de elétrons por efeito de campo, da Central Analítica do Instituto de Química da USP e, um microscópio eletrônico de varredura (SEM- 
FEG), modelo JSM 6701F, marca JEOL, CCTM - IPEN. As análises semiquantitativas de elementos químicos foram realizadas com apoio de sonda e programa EDS QUANTA - INCA Projects.

\subsubsection{Microscopia Confocal}

Utilizou-se um microscópio confocal LEXT OLS 4100, da Olympus, disponível no Laboratório de Análise de Materiais da Universidade Federal do $A B C$ (UFABC), para se determinar: altura, profundidade, largura, rugosidade, topografia e perfilometria nas regiões texturizadas, com marcação a laser, sem marcação e, na região interfacial entre marcações, bem como para se estimar formatos e profundidades de pites de alguns espécimes após polarização cíclica. Na Figura 8 está apresentado o equipamento em questão.

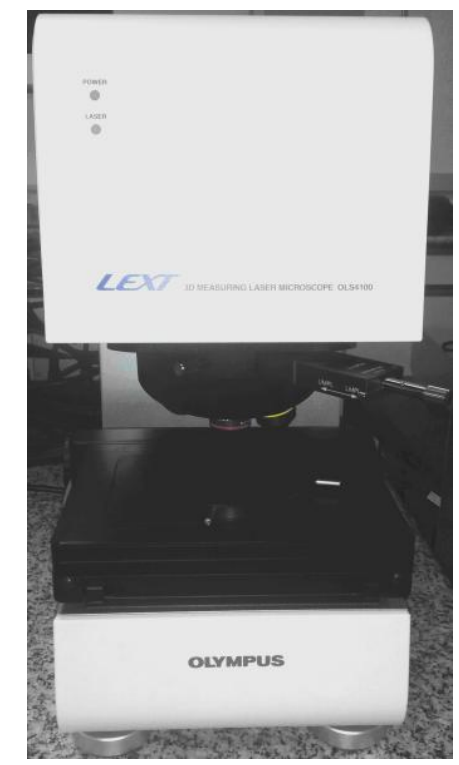

Figura 8. Microscópio confocal.

\subsection{Análises Topográficas}

O equipamento usado para avaliar a rugosidade foi um rugosímetro convencional da marca Mitutoyo - SJ301; e para avaliar a rugosidade topográfica, um microscópio eletrônico de varredura (MEV) de baixo vácuo com filamento de 
tungstênio e aproximação máxima de 10.000 vezes, marca: Hitachi, modelo: TM3000, com software para aquisição de dados topográficos, 3D Viewer.

Com o intuito de se obter maior qualidade de definição nos resultados topográficos, principalmente no tocante ao acabamento superficial das amostras texturizadas por feixe laser, foi utilizado um microscópio confocal LEXT OLS 4100 da Olympus e um microscópio de força atômica (AFM) da Bruker, modelo SPM Multimode 8, com software para processamento de análises Nanoscope Analysis.

\subsection{Análises de Microdureza}

As análises de microdureza Vickers foram realizadas em microdurômetro com microscópio óptico acoplado, Fisherscope HM 2000 alocado no Laboratório de Corrosão e Tratamento de Superfícies do CCTM - IPEN. Estas análises foram realizadas nas amostras sem tratamento (padrão de referência) e texturizadas por laser. Foram tomadas cinco medidas a uma distância de $50 \mu \mathrm{m}$ entre cada indentação, e imagens foram obtidas com amplitude de quarenta vezes (40x).

\subsection{Difração de Raios X (DRX)}

Para a caracterização da estrutura cristalográfica das amostras com e sem tratamento por feixe laser, foram realizadas análises de difração de raios $\mathrm{X}$, em difratômetro Rigaku-D-Max 2000, com tubo de Cu-Ka de comprimento de onda $0,154 \mathrm{~nm}$, e faixa de ângulos entre $5^{\circ}$ e $100^{\circ}$, alocado no Laboratório de Difração de Raios X do CCTM - IPEN. A limpeza dos espécimes foi realizada com acetona.

\subsection{Espectrometria de Fluorescência de Raios X (FRX)}

Foi utilizado um espectrômetro de fluorescência de raios $\mathrm{X}$ por dispersão de energia ED-XRF, da marca Shimadzu, do Centro de Química e Meio Ambiente (CQMA) do IPEN; sob vácuo menor que $30 \mathrm{~Pa}$ e que utiliza como detector um 
semicondutor de Si-Li. Para as três condições de acabamento superficial, ou seja, como recebido, texturizado e marcado a laser, foram utilizadas as seguintes condições: tensão de $15 \mathrm{kV}$, corrente de $1000 \mu \mathrm{A}$ e tempo de $60 \mathrm{~s}$ para varredura dos elementos entre o $\mathrm{Na}$ e Sc e, tensão de $50 \mathrm{kV}$, corrente de $100 \mu \mathrm{A}$ e, tempo igual a $40 \mathrm{~s}$ para varredura dos elementos entre o Ti e o U.

\subsection{Análises de Textura}

Para a caracterização da textura das amostras com e sem tratamento por feixe laser, foram realizadas análises de difração de raios $X$, em equipamento da Rigaku, alocado no Laboratório de Difração de Raios X do CCTM - IPEN.

\subsection{Ensaios Eletroquímicos}

A caracterização da resistência à corrosão localizada do biomaterial, com tratamento a laser com diferentes parâmetros, apresentados anteriormente, bem como o material como recebido (padrão de referência), foi realizada por métodos eletroquímicos. Os ensaios eletroquímicos foram conduzidos em um equipamento potenciostato / galvanostato da Bio-Logic, com software Ec-Lab v 10.33, disponível no Laboratório de Corrosão do IPEN, utilizando-se célula vítrea, apresentada na Figura 9, com três eletrodos, consistindo em um eletrodo de trabalho com área exposta para os ensaios de $1,0 \mathrm{~cm}^{2}$, um contra-eletrodo de platina e um eletrodo de referência de calomelano saturado.

Foram realizados um total de dez (10) ensaios para cada tipo de condição de acabamento superficial, totalizando noventa (90) testes; a saber: 10 ensaios para as amostras como recebido, 10 ensaios para cada um dos quatro parâmetros usados nas texturizações e 10 para cada um dos quatro parâmetros usados nas marcações, a fim de se garantir a reprodutibilidade das condições.

Os ensaios realizados consistiram em: monitoramento do potencial de corrosão em circuito aberto, espectroscopia de impedância eletroquímica, polarização cíclica, avaliação de propriedades do filme passivo pelo método de 
Mott-Schottky e técnica eletroquímica de varredura com eletrodo vibrante (SVET) em célula e equipamento apropriados.

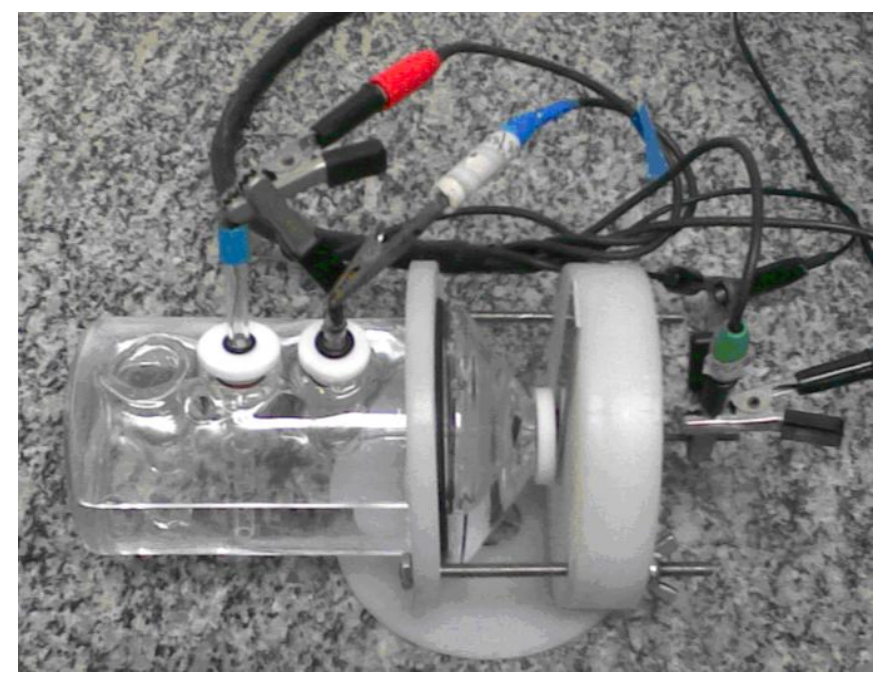

Figura 9. Célula plana de três eletrodos utilizada para os ensaios eletroquímicos.

\subsubsection{Potencial de Circuito Aberto (PCA)}

O monitoramento da variação do potencial de corrosão em função do tempo de imersão das amostras como recebidas e com tratamento de texturização e marcação a laser foi acompanhado ao longo de doze (12) horas em solução salina de fosfato tamponada (PBS) de $\mathrm{pH} 7,4$; segundo a norma ABNT NBR 15613-2:2010 [74], meio que simula a composição dos fluidos corpóreos, cuja composição química é mostrada na Tabela 3 , a seguir; naturalmente aerada a temperatura de $37^{\circ} \mathrm{C}$.

Tabela 3. Composição química (g/L) da solução salina de fosfato tamponada (PBS).

\begin{tabular}{c|c|c|c}
\hline $\mathrm{NaCl}$ & $\mathrm{KCl}$ & $\mathrm{Na}_{2} \mathrm{HPO}_{4}$ & $\mathrm{KH}_{2} \mathrm{PO}_{4}$ \\
\hline 8,0 & 0,2 & 1,15 & 0,2 \\
\hline
\end{tabular}

\subsubsection{Espectroscopia de Impedância Eletroquímica (EIE)}

As amostras do aço inoxidável austenítico ABNT NBR ISO 5832-1, com e sem tratamentos a laser, imersas em solução PBS, na temperatura de $37^{\circ} \mathrm{C}$ 
foram avaliadas quanto ao seu comportamento eletroquímico. Os espectros de impedância eletroquímica foram gerados após 12 horas de imersão. Todas as medidas de EIE, (dez para cada condição de acabamento de superfície), foram realizadas no potencial de circuito aberto, utilizando-se um sinal de perturbação senoidal com amplitude de $10 \mathrm{mV}$, na faixa de frequências de $10 \mathrm{kHz}$ até $10 \mathrm{mHz}$, taxa de aquisição de dados de 10 pontos por década. Todos os dados foram obtidos por meio de um analisador de respostas em frequências acoplado ao potenciostato da Bio-Logic.

\subsubsection{Polarização Potenciodinâmica Cíclica}

Todos os ensaios de polarização potenciodinâmica cíclica foram conduzidos na mesma solução PBS naturalmente aerada a $37^{\circ} \mathrm{C}$, que corresponde à temperatura corpórea, no mesmo equipamento já mencionado.

Vale ressaltar que este método foi propositalmente concebido para atingir condições que fossem suficientemente rigorosas para causar ruptura da camada passiva dos biomateriais, não necessariamente sendo encontradas in vivo.

De acordo com a norma ABNT NBR 15613-2:2010 [74], as amostras foram preparadas de modo que a região exposta à solução de ensaio esteja nas mesmas condições metalúrgicas e de superfície que a forma do dispositivo médico implantável.

Segundo esta mesma norma, a velocidade de varredura pode afetar o potencial de ruptura do biomaterial e a forma da região passiva da curva. A velocidade de varredura utilizada, na direção anódica, foi de 0,167 mV.s $\mathrm{s}^{-1}$.

Para selecionar materiais em um tempo razoável, os processos de corrosão têm que ser induzidos ou acelerados de alguma maneira, já que a grande maioria dos biomateriais para a fabricação de implantes não pode ser selecionada sob o aspecto da corrosão com ensaios de imersão convencionais, por resultar em perda de massa irrisória durante um longo período de pesquisa. 


\subsubsection{Abordagem de Mott-Schottky para Avaliação de Propriedades Eletrônicas do Filme Passivo}

As propriedades eletrônicas do filme passivo formado sobre as amostras do aço inoxidável austenítico ABNT NBR ISO 5832-1, sem tratamento e com marcações e texturizações a laser, imersas em solução PBS, na temperatura de $3^{3} \mathrm{C} \mathrm{C}$ foram determinadas por meio da técnica de Mott-Schottky.

As medidas de capacitância foram realizadas a $1 \mathrm{kHz}$ de frequência. $A$ polarização foi aplicada a passos sucessivos de $50 \mathrm{mV}$ na direção catódica a partir de $500 \mathrm{mV}$ até $-1000 \mathrm{mV}$.

A interface óxido / eletrólito para um semicondutor tipo-n e um semicondutor tipo-p foi descrita pela expressão de Mott-Schottky, apresentada nas equações 3 e 4, onde $C$ é a capacitância da interface filme passivo / eletrólito, $E$ é o potencial aplicado, $\varepsilon$ é a constante dielétrica da película passiva e possui valor igual a 12, de acordo com Ahn e Kwon [75], (tanto para o óxido de ferro como para o óxido de cromo), $\varepsilon_{0}=8,85.10^{-14} \mathrm{~F} . \mathrm{cm}^{2}$ é a permissividade do vácuo, $\mathrm{N}_{\mathrm{q}}$ é a densidade de doadores ou aceitadores para um semicondutor do tipo-n ou do tipo-p, respectivamente, $q=1,602 \cdot 10^{-19} \mathrm{C}$ é a carga elementar, $k$ é a constante de Boltzmann, $T$ é a temperatura absoluta e $E_{b p}$ é o potencial de banda plana.

\subsubsection{Técnica Eletroquímica de Varredura com Eletrodo Vibrante (SVET)}

Um equipamento SVET, da Applicable Electronics Inc., com câmera de imagens Panasonic e softwares ASET e QUICKGRID do Laboratório de Processos Eletroquímicos e Corrosão da Universidade Federal do Rio Grande do Sul (UFRGS), utilizando-se células poliméricas, vedação com adesivo epóxi, e eletrodo de referência de Calomelano Saturado foi empregado para analisar as amostras deste biomaterial nas condições de tratamento por feixe laser mencionadas anteriormente, após diferentes períodos de imersão em solução de PBS. O eletrodo foi posicionado a uma distância de $50 \mu \mathrm{m}$ das amostras, com 'grid' de $18 \mathrm{~mm} \times 28 \mathrm{~mm}$ e o tempo total de varredura foi de 6 minutos para cada mapa gerado, com distância aproximada de $100 \mu \mathrm{m}$ entre pontos. 


\subsection{Espectroscopia de Fotoelétrons Excitados por Raios X (XPS)}

A técnica de espectroscopia de fotoelétrons excitados por raios X (XPS) foi utilizada para determinar a composição química dos óxidos formados sobre as superfícies das amostras deste biomaterial, empregando-se um espectrômetro de superfícies da Thermo Fisher Scientific, modelo K-Alpha+, com fonte de Al K- $\alpha$, disponível na Universidade Federal do ABC (UFABC).

O princípio de XPS estabelece que raios $\mathrm{X}$ com energia hv incidem sobre a amostra excitando elétrons, que escapam com uma energia cinética, EC, dada pela relação de Einstein, $E C=h v-E L$, onde EL é a energia de ligação do elétron emitido em relação ao nível do vácuo. Como a energia dos raios $X$ é bem definida, os fotoelétrons ejetados têm uma distribuição de energia cinética constituída por picos discretos. Os caminhos livres médios destes fotoelétrons nos sólidos são de apenas 0,5 a 3,0 nm, ou seja, apenas a superfície do material está sendo analisada.

A identificação dos elementos presentes na superfície é feita diretamente pela determinação das energias de ligação dos picos fotoelétricos. A intensidade dos picos fornece informação quantitativa sobre a composição da superfície, enquanto que a posição de cada pico indica o estado químico do átomo emissor.

Vários fatores podem contribuir para os deslocamentos das energias de ligação dos elétrons de um átomo em um sólido, sendo os principais deles: (i) diferenças na densidade de elétrons de valência do átomo emissor, (ii) campo de potencial cristalino, (iii) função trabalho e (iv) energia de relaxação [76]. O chamado deslocamento químico é atribuído ao primeiro dos fatores citados [7778]. Para sólidos com energias de ligação referenciadas ao nível de Fermi, o deslocamento químico de um átomo $A$ em dois locais (1 e 2) quimicamente diferentes é dado pela relação: $\Delta \mathrm{E}_{\mathrm{L}}=\mathrm{E}_{\mathrm{L}, \mathrm{A} 1}-\mathrm{E}_{\mathrm{L}}$, A2.

As análises por XPS foram feitas em ambiente de ultra-alto vácuo (pressão de aproximadamente $3 \times 10^{-8}$ Torr). Foram realizados "snapshots" para caracterização instantânea de distribuição de elementos presentes em área de 2,0 $\mathrm{mm}^{2}$ e "Survey" em pontos aleatoriamente distribuídos na superfície. O ajuste dos picos foi feito utilizando-se o programa fornecido pelo fabricante do equipamento. 


\subsection{Análise por Ativação Neutrônica}

Extratos da solução salina tamponada de fosfato (PBS) foram recolhidos e reservados em frascos de polietileno com cerca de $40 \mathrm{~mL}$ após o término dos ensaios eletroquímicos, para se determinar a quantidade de elementos químicos que realmente foi desprendida das superfícies dos biomateriais e migraram para a solução que simula os fluidos corpóreos.

Foram analisadas cinco (5) amostras líquidas de extratos. Cada amostra correspondia ao tipo de tratamento de superfície recebido, a saber: quatro amostras texturizadas com feixe laser de fibra óptica, com os parâmetros mencionados anteriormente e, uma amostra de solução de PBS.

Cerca de $0,10 \mathrm{~mL}$ de cada extrato foi pipetado em cápsulas de polietileno de alta pureza e submetidos à secagem em temperatura ambiente para determinação de $\mathrm{Cl}$ e $\mathrm{Mn}$, por meio de irradiação curta de 20 s no reator. Os padrões dos elementos $\mathrm{Cr}$, Fe, K, Mo, Na e Ni foram preparados com irradiação longa de 16 horas em amostras de 1,0 mL; após a secagem foram submetidos a irradiação sob fluxo de nêutrons da ordem de $4 \times 10^{12} \mathrm{n} \cdot \mathrm{cm}^{-2} \cdot \mathrm{s}^{-1}$ do reator nuclear IEA-R1. Após alguns tempos de decaimento, as atividades gama foram medidas em detector de Ge (germânio) hiperpuro ligado a um espectrômetro de raios gama. Os radioisotópos formados foram identificados pela meia vida e energias de raios gama. As concentrações foram calculadas por método comparativo.

\subsection{Caracterização Magnética}

\subsubsection{Técnica de Análise de Permeabilidade Magnética}

A fim de se investigar alterações nas propriedades magnéticas do aço inoxidável austenítico ISO 5832-1, que indicam a formação de fase magnética (ferrita), foram realizados ensaios de medição de permeabilidade magnética relativa $\left(\mu_{r}\right)$ das amostras. Estas medidas foram realizadas com auxílio de um dispositivo constituído por um imã posicionado sobre um pedestal, que é apoiado no prato de uma balança analítica (balança de susceptibilidade magnética). A força magnética exercida pela amostra sobre o imã altera a leitura do peso. 
Esta propriedade foi medida antes e depois dos tratamentos de marcação e texturização, utilizando-se um imã de $\mathrm{NdFeB}$ cúbico de 6,3 mm de aresta com momento magnético de $\mathrm{m}_{\mathrm{d}}=0,2518 \mathrm{Am}^{2}$. Uma amostra como recebida foi mantida como referência para o ajuste do equipamento de medição antes de cada caracterização magnética.

\subsubsection{Técnica de Microscopia de Força Magnética (MFM)}

Um microscópio de força magnética (MFM) da Bruker, modelo SPM Multimode 8, com software para processamento de análises Nanoscope Analysis, foi utilizado no modo de operação Tapping Mode para a realização de medições de campo magnético naturalmente gerado sobre as superfícies das amostras texturizadas a laser.

A técnica de microscopia de força magnética consiste na obtenção de imagens da variação do campo magnético ao longo de uma dada superfície. Para tanto, se faz necessária a utilização de uma ponta recoberta por um filme fino de material ferromagnético, com imantação permanente. A ponta oscila próximo à superfície da amostra, mas sem tocá-la, com oscilação entre 1 e $10 \mathrm{~nm}$. A força magnética gera uma perturbação no movimento oscilatório. Utiliza-se o recurso "interleave com lift mode", onde as medidas são obtidas em duas etapas, realizadas em cada linha de varredura [79].

A detecção de força magnética realiza-se com outro modo de operação do microscópio de força atômica (AFM). Para amostra e ponteira magnéticas, quando a ponteira se aproxima da superfície da amostra dentro de uma distância de 10 a $500 \mathrm{~nm}$, é possível perceber a interação magnética da ponteira com o campo que emana da amostra. A interação dipolar magnética é de longo alcance e detecta-se usando o método de AC, ou seja, mede-se gradiente de força. Portanto, também para um MFM o método operacional é o de não-contato [79].

Como as forças magnéticas $\left(F_{\text {mag }}\right)$ podem ser atrativas ou repulsivas, podem ocorrer problemas com a estabilidade do sistema de realimentação no modo de não-contato e a ponteira pode bater na superfície. Para solucionar isto, se requer uma força atrativa adicional $F_{\text {servo, chamada força "servo", cuja }}$ grandeza aumente quando a ponteira se aproxime da superfície da amostra. As 
forças de van der Waals de curto alcance, que estão sempre presentes, poderiam servir como forças servo, mas às vezes não funcionam, talvez devido à condensação de líquidos entre a ponteira e a amostra. Entretanto, o problema é resolvido introduzindo uma força eletrostática atrativa adicional controlável $F_{\text {el }}$ induzida pela aplicação de um potencial de bias da ordem de 1 a $10 \mathrm{~V}$ entre a ponteira e a amostra. Desta forma, a força aumenta com a diminuição da distância entre a ponteira e a amostra. O gradiente total de força F', medido pelo método de detecção de $\mathrm{AC}$, é dado pelo gradiente da força que age sobre o cantilever:

$$
F^{\prime}=F_{\text {mag }}^{\prime}+F_{\text {servo }}^{\prime}=F_{\text {mag }}^{\prime}+F_{v d W}^{\prime}+F_{e l}^{\prime}
$$

O gradiente de força constante pode refletir não apenas contraste

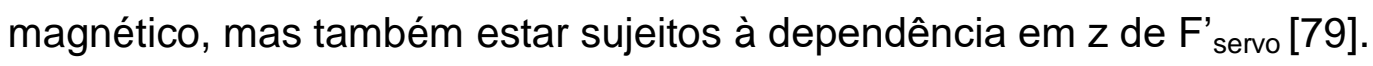

\subsection{Ensaios Biomecânicos dos Biomateriais}

Os ensaios biomecânicos empregados nesta pesquisa consistiram na realização de ensaios mecânicos em corpos-de-prova de biomateriais utilizados na fabricação de dispositivos ortopédicos implantáveis, com acabamento superficial sem laser (padrão de referência) e com tratamentos de marcação e texturização a laser. Os testes executados foram:

\subsubsection{Resistência à Fadiga}

Os ensaios de resistência à fadiga foram conduzidos em uma máquina Instron, Electroplus, alocada no Laboratório de Mecânica dos Sólidos e Impacto em Estruturas do Departamento de Engenharia Mecânica da Escola Politécnica da USP. Foi utilizado um carregamento de $100 \mathrm{kN}$, em $30 \mathrm{~Hz}$ de frequência, com tensão média de $7,5 \mathrm{kN}$ e amplitude de tensões $2 \mathrm{kN}$, em regime tração-tração. Foram realizados quatro ensaios conduzidos ao ar em temperatura ambiente de $25^{\circ} \mathrm{C}$. 


\subsubsection{Resistência à Tração}

Os testes de resistência mecânica à tração das amostras nas condições como recebida, marcadas e texturizadas a laser foram realizados em equipamento padronizado, máquina universal de ensaios mecânicos MTS, Figura 10, disponível no Laboratório de Ensaios mecânicos do CCTM-IPEN. A velocidade de deslocamento do travessão foi de $0,50 \mathrm{~mm} \cdot \mathrm{min}^{-1}$. Foram realizados 6 (seis) testes, normatizados, para cada condição de acabamento superficial, em corpos-de-prova de tamanho sub-size conforme ASTM E8 / E8M -11.

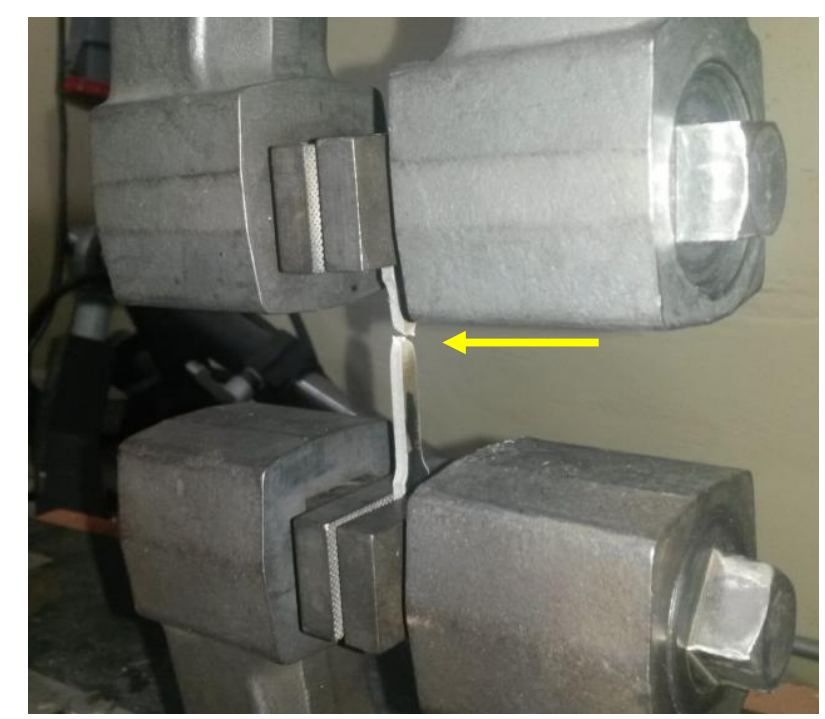

Figura 10. Equipamento para ensaio de tração. A seta está indicando a região de fratura do corpo-de-prova.

\subsubsection{Resistência ao Desgaste}

A análise do comportamento bio-tribológico do biomaterial, com e sem tratamento por feixe laser, foi efetuada através de ensaios de desgaste em solução de fosfato tamponada (PBS) que simula os fluidos corpóreos, a fim de prever situações reais encontradas na prática cirúrgica; o que reforça o inedistismo desta pesquisa. Os biomateriais utilizados como contra-corpo foram esferas metálicas de aço inoxidável 316L, de 1 polegada de diâmetro. Os parâmetros do equipamento foram: força normal de $0,25 \mathrm{~N}$, frequência de rotação de $50 \mathrm{rpm}$ e velocidade de $0,066 \mathrm{~m} \cdot \mathrm{s}^{-1}$, de acordo com o protocolo do Laboratório 
de Engenharia Mecânica do Centro Universitário da Fundação Educacional Inaciana (FEI).

O volume de desgaste foi calculado em função de $b$ (raio da cratera) e $R$ (raio da esfera), utilizando-se a equação a seguir, que é válida para $b \ll R$ :

$$
V \cong \frac{\pi b^{4}}{64 R} \quad \text { (Equação 5) }
$$

Na Figura 11 está apresentado o equipamento alocado no Laboratório de Engenharia Mecânica do Centro Universitário da FEl.

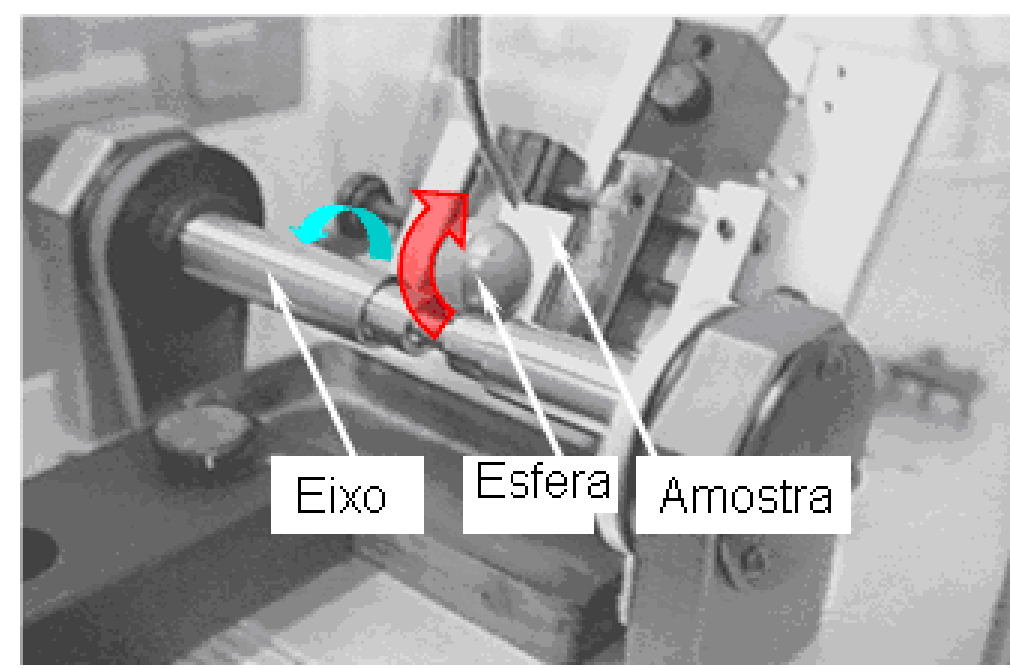

Figura 11. Equipamento para ensaio de desgaste por esfera livre rotativa.

\subsubsection{Resistência ao Desgaste em Nanotribômetro}

A análise do comportamento bio-tribológico destes biomateriais, com e sem tratamento de marcação e texturização por feixe laser, também foi verificada em equipamento nanotribômetro, modelo $\mathrm{NTR}^{2}$, da Anton Paar. Os testes foram realizados ao ar, em temperatura ambiente de $25^{\circ} \mathrm{C}$ e sem fluido lubrificante, com contra-corpo de aço-cromo 52-100 em formato de esferas rotativas, com $2 \mathrm{~mm}$ de diâmetro, por tempos de ensaio de 1 minuto. $O$ equipamento utilizado está apresentado na Figura 12. 


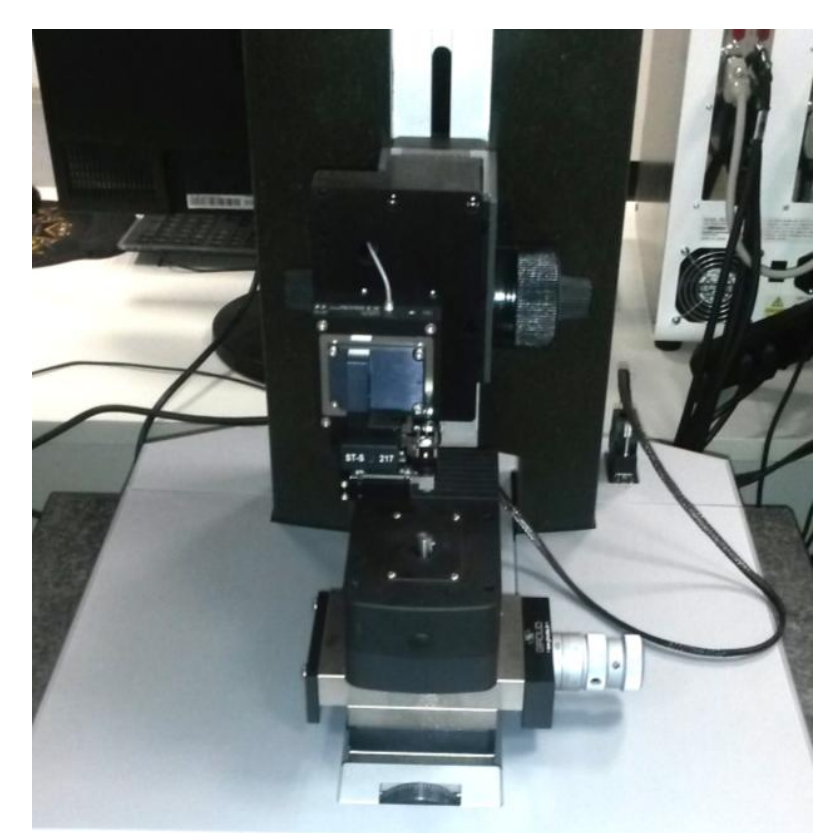

Figura 12. Equipamento para ensaio de nanotribologia.

\subsubsection{Análise de Superfície de Fratura e Cratera de Desgaste}

As superfícies de fratura e cratera de desgaste foram verificadas por inspeção visual, estereoscópica e microscopia óptica. As imagens obtidas estão apresentadas na seção de Resultados e Discussão.

\subsection{Ensaio de Citotoxicidade}

A citotoxicidade foi avaliada por meio de metodologia quantitativa. O ensaio baseia-se na determinação de células viáveis após a exposição da população celular a diversas concentrações do extrato, que foi obtido a partir da incubação prolongada das amostras em meio de cultura celular RPMI (Gibco ${ }^{\circledR}$ ) com soro fetal bovino, a 37ํㅡ por 9 (nove) dias sob constante agitação.

A análise da quantidade de células viáveis foi realizada por metodologia colorimétrica, pela incorporação de corante supravital e um agente acoplador de elétrons (MTS/PMS) e posterior leitura em espectrofotômetro a 490nm. A quantidade de corante incorporada pela população celular é diretamente proporcional ao número de células viáveis em cultura. 
A relação entre a concentração do extrato e a quantidade de células viáveis resultou em uma curva dose-resposta e o $\mathrm{Cl}_{50 \%}$ é um parâmetro utilizado para avaliação da citotoxicidade, que é a concentração do extrato que aniquila $50 \%$ das células expostas no teste $(\mathrm{Cl}$ - Concentração Inibitória). A preparação dos extratos foi feita de acordo com a ISO 10993-12 [80], foram usados como controle positivo; Fenol 0,5\%; e como controle negativo: titânio comercial, e como sistema teste, células da linhagem $\mathrm{CHO}-\mathrm{K} 1$ derivado de ovário de hamster chinês. 


\section{RESULTADOS E DISCUSSÃO}

\subsection{Avaliações Macrográficas}

As amostras (conjunto de espécimes) de biomateriais utilizadas neste estudo, identificadas como 1, 2, 3 e 4 em função da alternância da frequência dos pulsos do laser de fibra óptica, de itérbio, apresentaram mudanças de coloração nas superfícies das amostras texturizadas, bem como nas amostras marcadas. Este aspecto está mais evidente nas amostras texturizadas por causa da maior área preenchida pelo laser, como pode ser observado nas Figuras 13 (a) e (b).

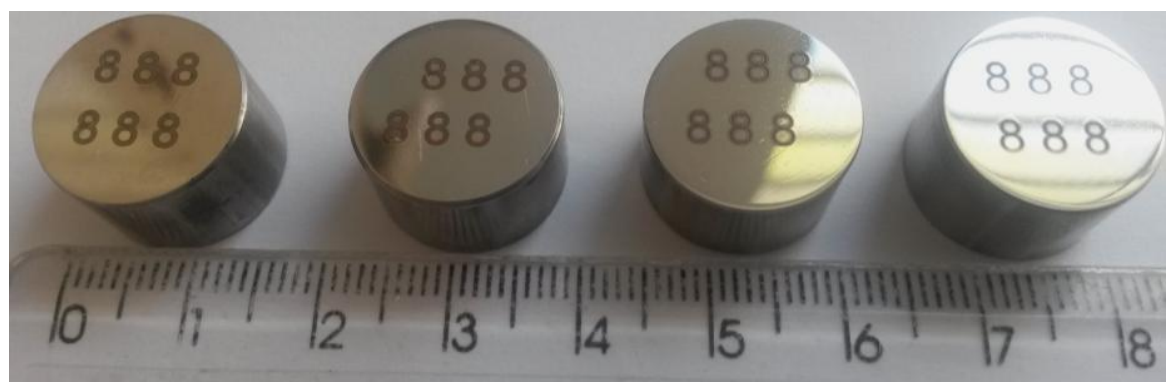

Figura 13 (a). Amostras marcadas a laser.

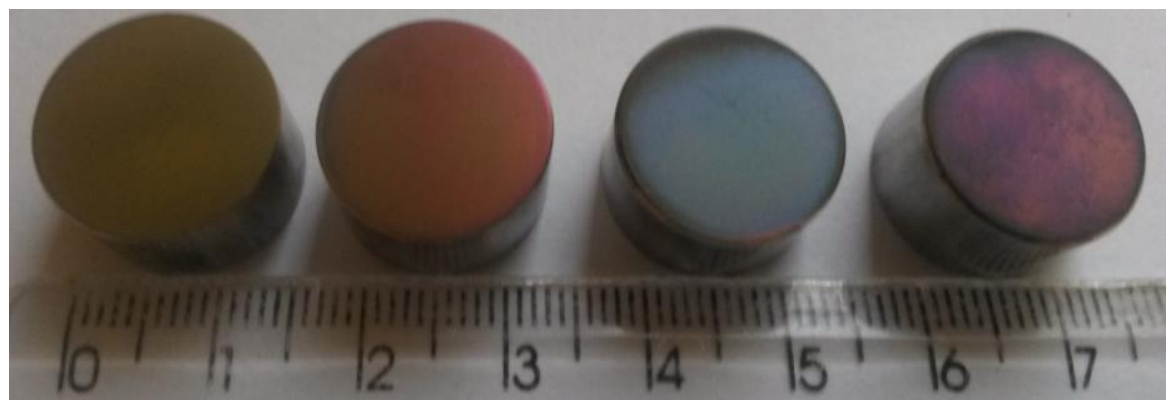

Figura 13 (b). Amostras texturizadas a laser.

As variações em colorações e tonalidades estão relacionadas a diferentes espessuras das camadas de óxidos formados. As imagens das amostras marcadas a laser apresentaram maiores reflexos de acordo com a luminosidade incidente, devido ao fato de somente uma pequena área ter sido marcada pelo laser, isto é, a área que compreende o algarismo 8; o restante, ou seja, a maior área da face possuía o acabamento superficial dado ao material padrão de referência, isto é, lixado e polido até $1 \mu \mathrm{m}$. Um critério para que a marcação seja eficiente é a sua visualização. 


\subsection{Análises Microestruturais}

Amostras do biomaterial utilizado nesta pesquisa foram caracterizadas quanto à sua microestrutura e estão adequadas para o seu emprego, pois atende às normas ASTM F-138, ASTM F-139 e ABNT NBR ISO 5832-1 que estabelecem as características microestruturais de aços inoxidáveis austeníticos para aplicações biomédicas. De acordo com estas normas, a microestrutura deve ser austenítica; o que foi confirmado pelas análises realizadas. Nas Figuras 14 (a) e (b) estão mostradas microestruturas do aço inoxidável ABNT NBR ISO 5832-1, após ataque eletrolítico em solução aquosa de ácido oxálico 10\%v por 1 minuto, obtidas por microscopia eletrônica de varredura.

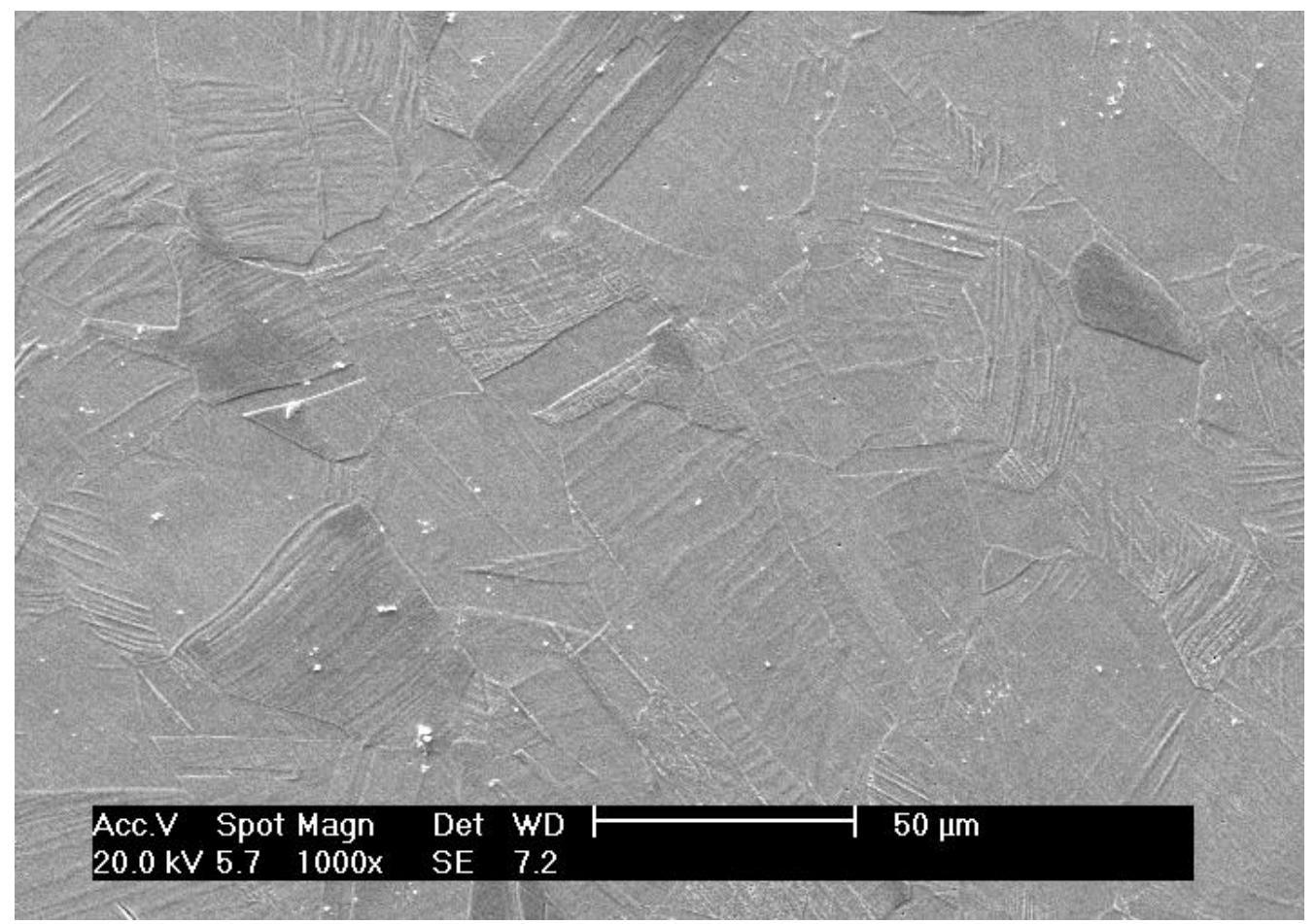

Figura 14 (a). Micrografia obtida por microscopia eletrônica de varredura da amostra do aço inoxidável estudado após ataque eletrolítico em ácido oxálico, 10\% 1 , min.

A micrografia mostrada na Figura 14 (a) é típica de material austenítico, com grãos recristalizados e maclas de recozimento. O tamanho de grão medido foi da ordem de $30 \mu \mathrm{m}$, que atendeu às normas. Na Figura 14 (b) está apresentada a microestrutura do aço na secção transversal da amostra marcada por feixe laser. As setas indicam regiões com marcações. 


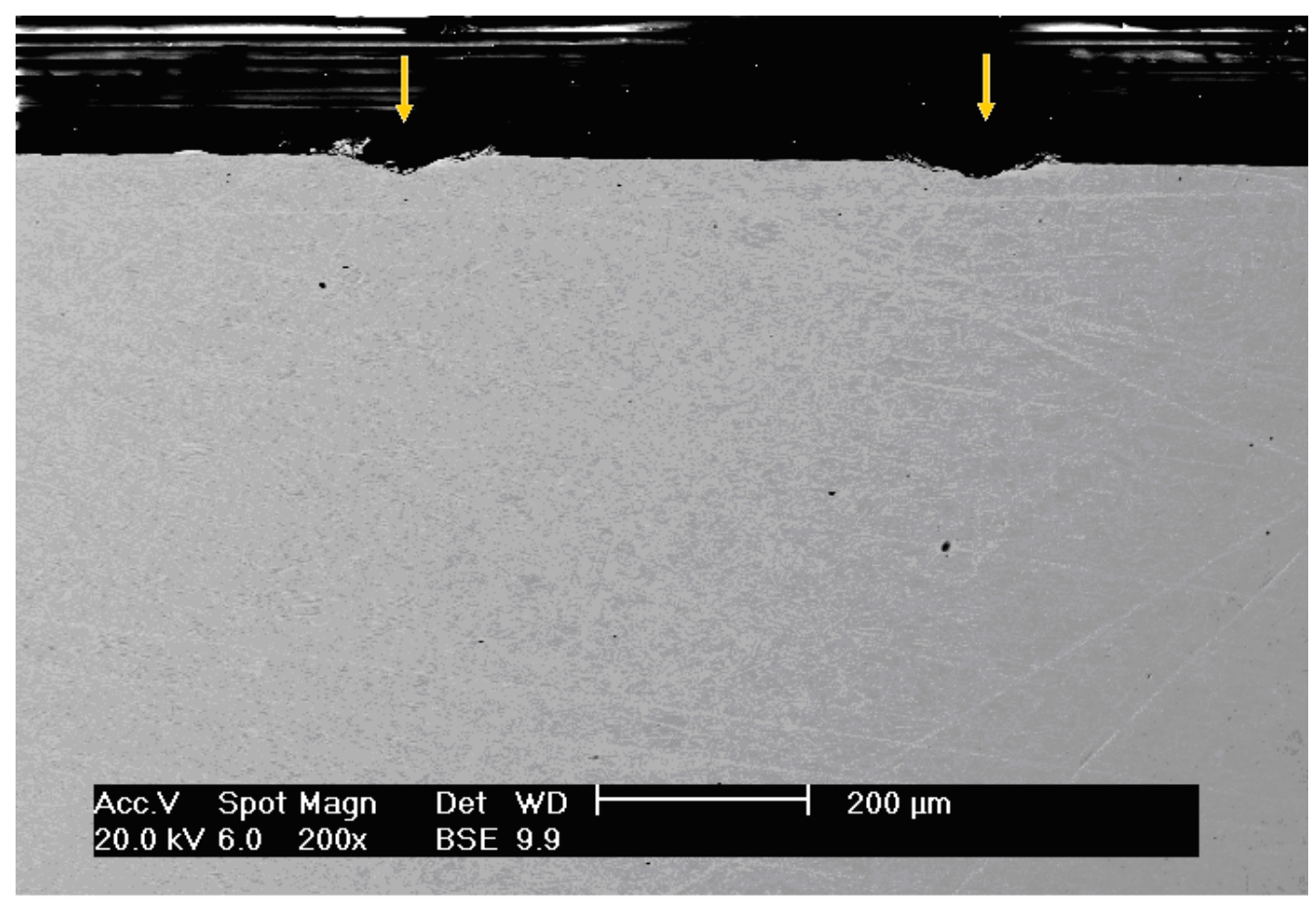

Figura 14 (b). Micrografia obtida por microscopia eletrônica de varredura da seção transversal da amostra marcada a laser após ataque eletrolítico com ácido oxálico, $10 \% \mathrm{~V}, 1 \mathrm{~min}$. As setas indicam as regiões com marcações a laser.

Neste caso, a região de incidência do feixe laser apresentou valores de profundidades inferiores a $30 \mu \mathrm{m}$.

\subsection{Análise Química}

A análise química do material utilizado neste trabalho foi obtida pela técnica de espectroscopia de emissão óptica conforme apresentado anteriormente na seção de Materiais e Métodos. Para fins de comparação, a composição química de amostras tratadas a laser nas condições já mencionadas e sem tratamento (padrão de referência) também foi avaliada por espectrometria de fluorescência de raios $X(F R X)$. Os resultados obtidos encontram-se na Tabela 4.

Tabela 4. Elementos químicos presentes na amostra do aço inoxidável ABNT NBR ISO 5832-1, pela técnica de espectrometria de fluorescência de raios $X$.

\begin{tabular}{c|c|l|c|c|c|c|c|c|c}
\hline Elementos & $\mathrm{C}$ & $\mathrm{Si}$ & $\mathrm{Mn}$ & $\mathrm{P}$ & $\mathrm{S}$ & $\mathrm{Cr}$ & $\mathrm{Mo}$ & $\mathrm{Ni}$ & $\mathrm{Fe}$ \\
\hline$\%$ massa & - & 0,38 & 1,84 & 0,09 & 0,18 & 17,55 & 3,26 & 14,78 & Bal. \\
\hline
\end{tabular}


A técnica de fluorescência de raios $X$ por energia dispersiva não apresentou alterações na composição dos elementos químicos nas amostras deste aço inoxidável em função da mudança de parâmetros do tratamento a laser.

\subsection{Análises Topográficas}

Os tratamentos superficiais por feixe laser provocam alterações de relevo dos biomateriais metálicos. Este efeito foi avaliado neste estudo a fim de se verificar mudanças qualitativas na topografia dos biomateriais tratados por laser de fibra óptica.

Nas Figuras 15 (a - e) estão apresentados alguns aspectos qualitativos da topografia dos biomateriais sem tratamento a laser e texturizadas com os parâmetros mencionados anteriormente.

As imagens foram obtidas por MEV de baixo vácuo com software para aquisição de dados topográficos.

Nota-se que a mudança no parâmetro frequência de pulso altera significativamente as topografias dos biomateriais, principalmente quando comparadas à amostra sem tratamento de texturização por feixe laser, conforme Figura 15 (a).

Qualitativamente, a frequência mais baixa, $\mathrm{f}=80 \mathrm{kHz}$, da amostra 1, Figura 15 (b) gerou um efeito topográfico semelhante ao da amostra sem texturização por laser, Figura 15 (a).

As frequências intermediárias, $f=188 \mathrm{kHz}$ e $\mathrm{f}=296 \mathrm{kHz}$, que correspondem às condições das amostras 2 e 3, conforme imagens apresentadas na Figura 15 (c) e (d), produziram superfícies mais onduladas; já as mais elevadas, $f=350 \mathrm{kHz}$, conferem superfícies com relevos com os maiores desníveis, com ondulações sugerindo regiões de picos e vales. Maiores frequências acarretam em maiores intensidades, ou seja, maior distribuição de potência por área. 


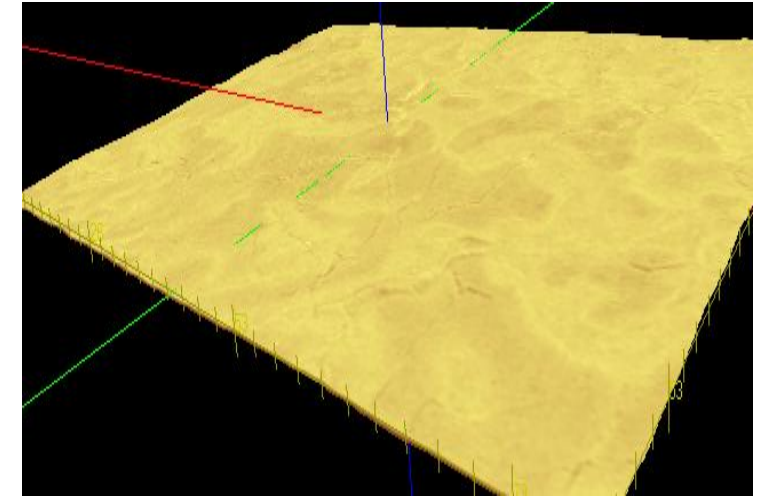

(a) Amostra padrão (sem laser)

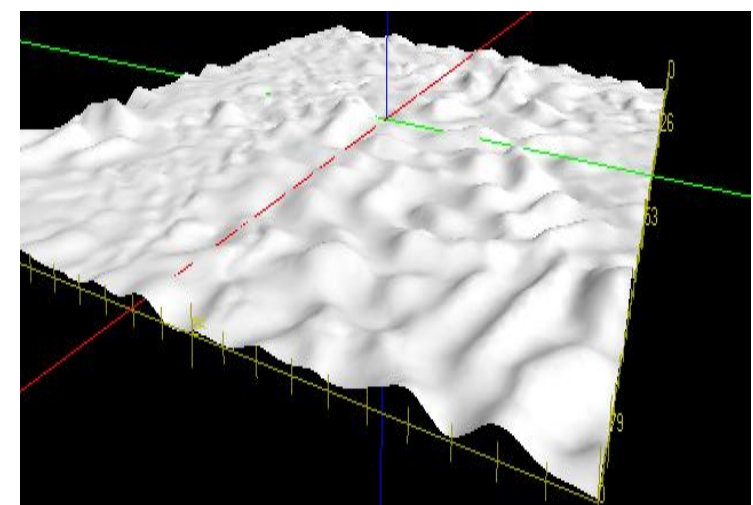

(c) Amostra texturizada $-2(188 \mathrm{kHz})$

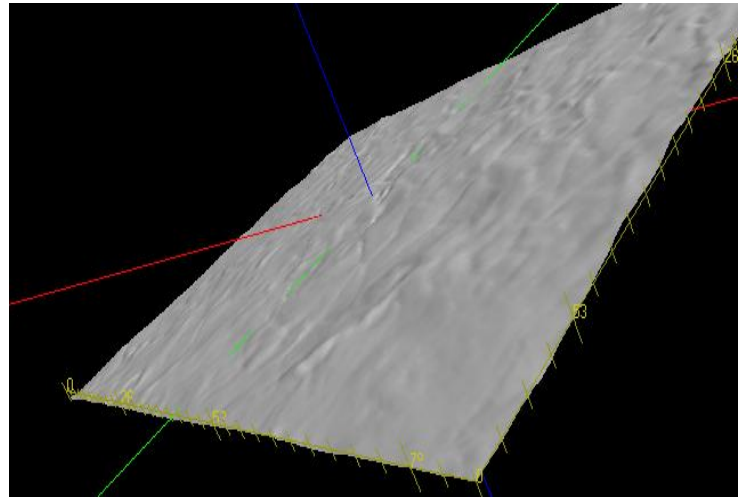

(b) Amostra texturizada -1 (80 kHz)

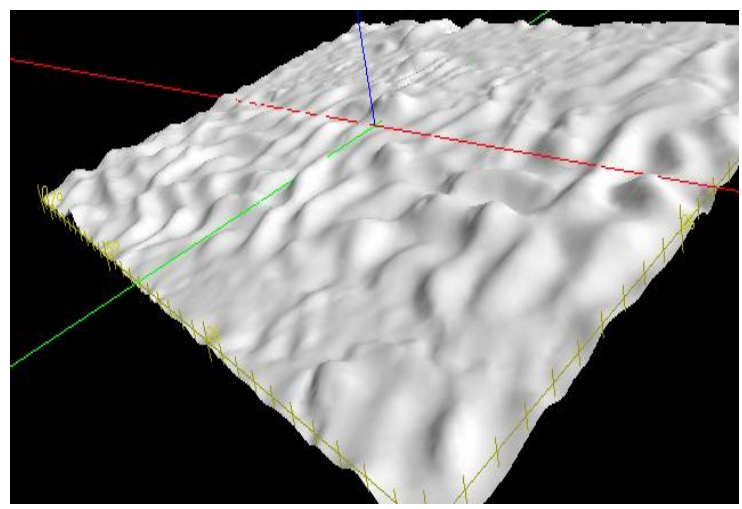

(d) Amostra texturizada - $3(296 \mathrm{kHz})$

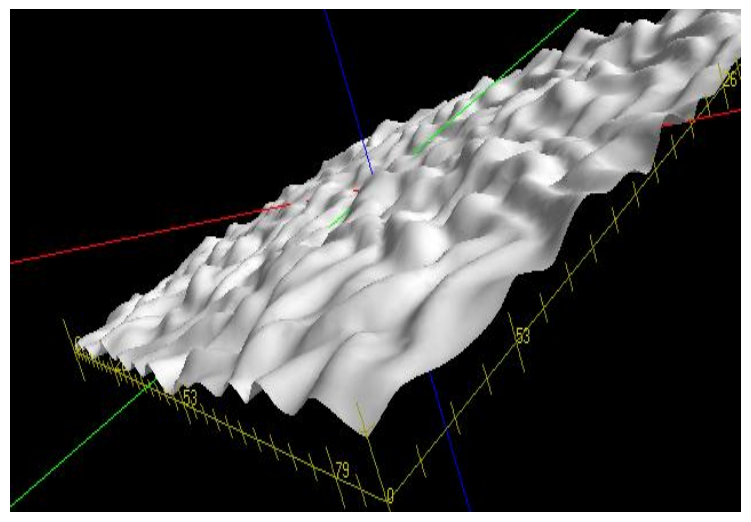

(e) Amostra texturizada $-4(350 \mathrm{kHz})$

Figura 15. Topografia dos biomateriais sem tratamento e texturizados a laser com os parâmetros pré-definidos, aumentando-se a frequência do laser, conforme designado pela sequência de 1 a 4. 


\subsection{Avaliação de Rugosidades}

A rugosidade das superfícies dos dispositivos médicos implantáveis é de extrema importância, pois ela contribui para o regime de aderência entre 0 implante e o tecido ósseo durante períodos de permanência diversos. Os parâmetros de rugosidade mais utilizados são: $\mathrm{Ra}, \mathrm{Rz}$ e Rq. Rugosidade média, Ra, é a média aritmética dos valores absolutos das ordenadas dos afastamentos dos pontos do perfil de rugosidade, em relação à linha média; Rz é a média aritmética de 5 valores da rugosidade parcial Zi. O parâmetro Rq é o desvio médio quadrático correspondente ao $\mathrm{Ra}$, sendo: $\mathrm{Rq} \approx 1,11$ a $1,25 \mathrm{Ra}$.

Nas amostras tratadas é possível verificar-se a fusão do material de base com afastamento de metal fundido na região de incidência do feixe laser, o que modifica a rugosidade destas superfícies. Este efeito foi avaliado em cinco espécimes para cada condição de amostra e as médias obtidas estão apresentadas nas Tabelas 5 e 6 . Os resultados de rugosidade mostram o efeito produzido por este tipo de laser, nas condições utilizadas, sobre este tipo de biomaterial em específico.

Tabela 5. Valores de rugosidades $(\mu \mathrm{m})$ obtidos por rugosímetro convencional para as amostras apresentadas nas Figuras 13 (a) e (b).

\begin{tabular}{c|c|c|c}
\hline Amostras & $\mathrm{Ra}(\mu \mathrm{m})$ & $\mathrm{Rz}(\mu \mathrm{m})$ & $\mathrm{Rq}(\mu \mathrm{m})$ \\
\hline 1-marcada & 0,46 & 2,18 & 0,55 \\
\hline 1-texturizada & 0,10 & 0,65 & 0,12 \\
\hline 2-marcada & 0,28 & 1,14 & 0,34 \\
\hline 2-texturizada & 0,13 & 0,81 & 0,17 \\
\hline 3-marcada & 0,79 & 3,67 & 0,97 \\
\hline 3-texturizada & 0,34 & 2,15 & 0,41 \\
\hline 4-marcada & 0,95 & 5,46 & 1,20 \\
\hline 4-texturizada & 0,41 & 2,41 & 0,59 \\
\hline Sem laser & 0,03 & 0,27 & 0,04 \\
\hline
\end{tabular}

Os resultados da Tabela 5 indicam que todas as condições de superfície analisadas, independentemente do aumento do parâmetro utilizado (frequência), produzem aumento da rugosidade em comparação com a amostra padrão, isto é, 
sem tratamento a laser. Com relação ao tipo de tratamento superficial, as amostras que receberam marcação a laser apresentaram maiores valores de rugosidade em relação às texturizadas, o que pode ser explicado pelo efeito da área, uma vez que as amostras texturizadas tiveram a incidência do feixe laser por toda a superfície, enquanto que nas com marcações, não ocorreram desta forma. No que se refere ao aumento da frequência do laser de 1 a 4 , respectivamente, $f=80,188,296$ e $350[\mathrm{kHz}]$, este correspondeu diretamente a um aumento nos valores de rugosidade.

Tabela 6. Valores de rugosidades ( $\mu \mathrm{m})$ obtidos por MEV de baixo vácuo com software de análise topográfica para as diferentes condições de texturização a laser para as amostras apresentadas na Figura 13 (b).

\begin{tabular}{c|c|c|c}
\hline Amostras & $\mathrm{Ra}(\mu \mathrm{m})$ & $\mathrm{Rz}(\mu \mathrm{m})$ & $\mathrm{Rq}(\mu \mathrm{m})$ \\
\hline 1 & 0,33 & 1,91 & 0,40 \\
\hline 2 & 0,58 & 4,11 & 0,71 \\
\hline 3 & 0,81 & 5,23 & 0,97 \\
\hline 4 & 0,88 & 4,16 & 1,04 \\
\hline Sem laser & 0,30 & 2,88 & 0,39 \\
\hline
\end{tabular}

Conforme apresentado na Tabela 6, as rugosidades das superfícies texturizadas que foram avaliadas por MEV de baixo vácuo com software para análise topográfica, também indicam um aumento nestes valores relacionados diretamente com o aumento na frequência utilizada para o tratamento a laser, mencionado anteriormente, quando comparadas entre si e em relação à amostra padrão utilizada como referência.

Comparando-se os resultados das Tabelas 5 e 6 obtidos para as amostras texturizadas nas condições utilizadas neste trabalho, nota-se uma discrepância nos valores obtidos para as rugosidades $R a, R z$ e $R q$, sendo os apresentados na Tabela 6 superiores aos da Tabela 5. Este fato é explicado pelas diferentes sensibilidades das técnicas empregadas, uma vez que a medida com o rugosímetro convencional consiste no contato direto de uma ponta metálica com a superfície da amostra. Isto explica o fato de algumas publicações [21, 22, 89] neste campo avaliarem e justificarem os resultados encontrados apenas do ponto de vista qualitativo do aspecto das topografias. 
Modificações nas superfícies de aços texturizadas a laser com diferentes parâmetros foram reportadas na literatura [81, 82]. Stašić et al. [81] realizaram texturizações nas superfícies de amostras do aço carbono AISI 1045 alterando-se as energias de pulso de um laser de Ti:safira de femtossegundos. Eles avaliaram qualitativamente mudanças nas topografias das amostras e identificaram que as mudanças produzidas nas superfícies tinham um caráter bem definido, classificadas como estruturas superficiais periódicas e estavam de acordo com o esperado para as condições de feixe de laser utilizadas.

Estes pesquisadores [81] ressaltaram, ainda, que o uso deste tipo de laser fornece modificações superficiais delicadas e precisas, de elevado interesse em aplicações nos campos da microeletrônica, óptica e medicina.

Analogamente, as superfícies marcadas e texturizadas por feixe laser de fibra óptica de $\mathrm{Yb}$, com pulsos de nanossegundos, no aço inoxidável austenítico ABNT NBR ISO 5832-1, utilizado como biomaterial, também apresentaram mudanças topográficas diretamente relacionadas com o aumento da frequência de pulso. Este efeito foi melhor visualizado nas superfícies texturizadas a laser, por se tratarem de áreas maiores.

\subsection{Avaliação de Microdureza}

O ensaio de microdureza foi realizado nas amostras com superfícies texturizadas com o intuito de se verificar a influência da alteração da frequência dos pulsos na microdureza dos biomateriais. Nas Figuras 16 são apresentadas imagens de microscopia óptica com aumento de 40 vezes e, para a condição padrão com aumento de 20 vezes, após o ensaio de microdureza. Foram observadas mudanças nas topografias deste biomaterial e nas colorações geradas nos óxidos das superfícies texturizadas. 


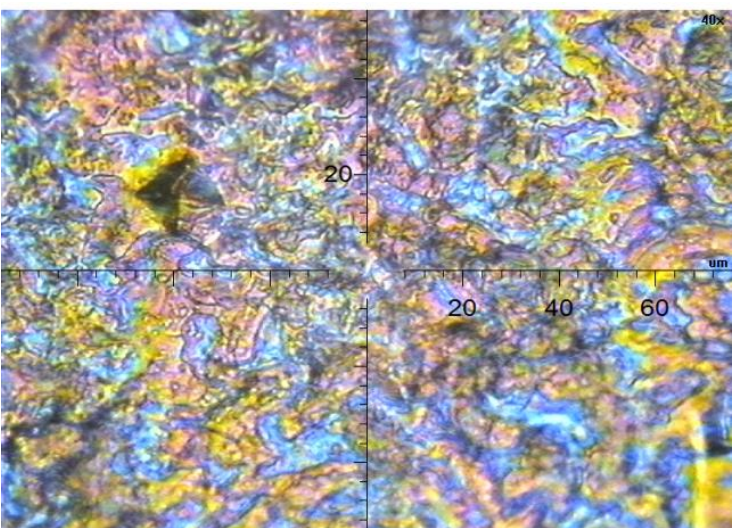

(a) Amostra 1

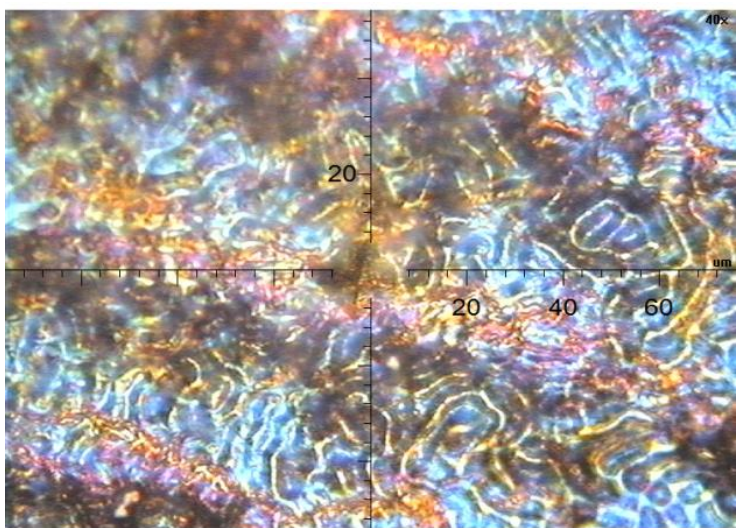

(c) Amostra 3

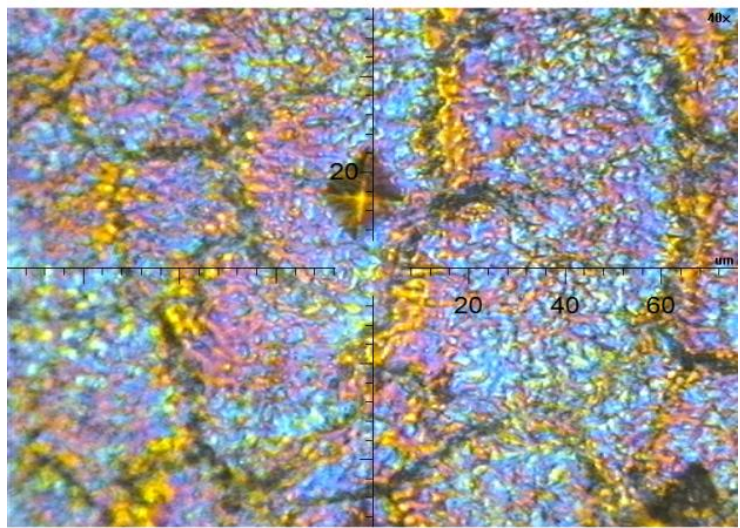

(b) Amostra 2

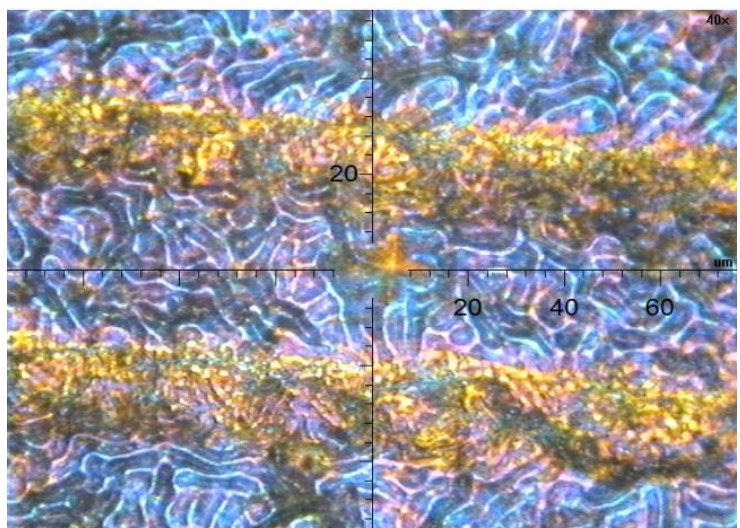

(d) Amostra 4

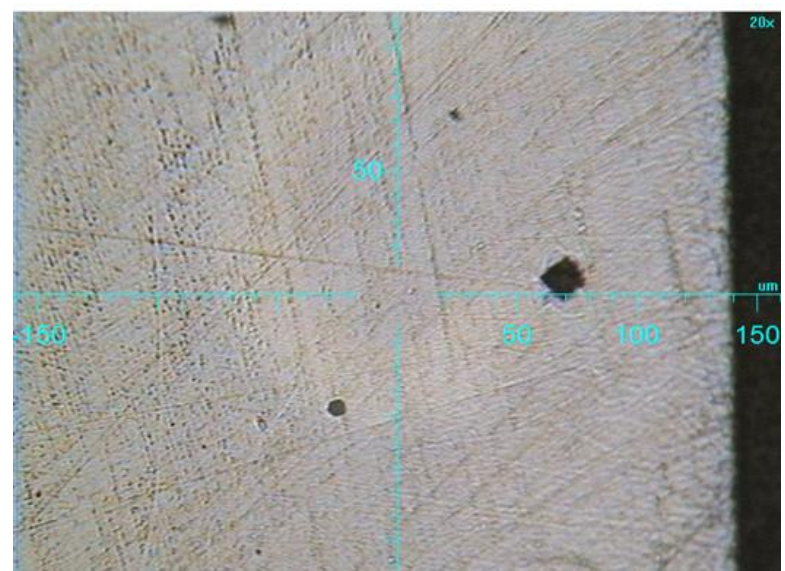

(e) Amostra padrão, sem tratamento a laser. Aumento 20x.

Figura 16. Microscopias ópticas das superfícies das amostras texturizadas por laser e padrão de referência, apresentando região de penetração da ponteira de microdureza Vickers. Sem ataque.

Na Tabela 7 estão apresentadas cinco medidas de microdureza Vickers tomadas para cada condição de texturização por laser e uma média destas medidas. As medidas foram realizadas a $50 \mu \mathrm{m}$ de distância umas das outras. 
Tabela 7. Medidas de microdureza Vickers para cada tipo de acabamento superficial de texturização por feixe laser e amostra padrão.

\begin{tabular}{c|c|c|c|c|c}
\hline Amostra & 1 & 2 & 3 & 4 & Padrão \\
\hline Média & $204,3 \pm 4,5$ & $215,4 \pm 12,0$ & $226,1 \pm 7,8$ & $239,9 \pm 12,6$ & $199,3 \pm 7,2$ \\
\hline
\end{tabular}

De acordo com a análise das médias das medidas de microdurezas, estas variam de acordo com a alternância dos parâmetros do laser, ou seja, o aumento no parâmetro frequência acarreta em um aumento das microdurezas da superfície de todas as amostras texturizadas. Nas imagens de microscopia óptica são nítidas as diferentes colorações obtidas com o processo de texturização das superfícies deste biomaterial com feixe laser. Nota-se que ao variar a frequência dos pulsos, os relevos e as colorações gerados sobre as superfícies também são variados, pois são formados óxidos de diferentes espessuras.

\subsection{Caracterizações das Superfícies}

A superfície do aço inoxidável foi caracterizada metalograficamente a fim de se investigar se as regiões tratadas com laser apresentaram mudanças microestruturais significativas que, por exemplo, afetassem a resistência à corrosão do aço. Nesta seção estão apresentadas imagens das amostras do biomaterial estudado obtidas empregando-se várias técnicas descritas anteriormente, nas condições: padrão de referência e tratadas com laser nos parâmetros citados anteriormente, ora identificados como amostras 1, 2, 3, e 4; atacadas por água régia e sem ataque metalográfico.

Nas Figuras 17, obtidas por MEV de baixo vácuo, são apresentados aspectos da superfície deste biomaterial após a texturização por laser com os parâmetros citados. A imagem da Figura 17 (e) é uma ampliação da superfície da amostra 4, texturizada com a maior frequência, apresentada na Figura 17 (d).

Nas imagens apresentadas nas Figuras $17(\mathrm{a}-\mathrm{d})$, com aumento de 600 vezes, fica evidente o efeito do laser nas superfícies deste biomaterial. As superfícies apresentam diferentes relevos, regiões de picos e vales e, notam-se nas Figuras 17 (a), (c) e (d) as linhas que indicam a trajetória do feixe laser. 


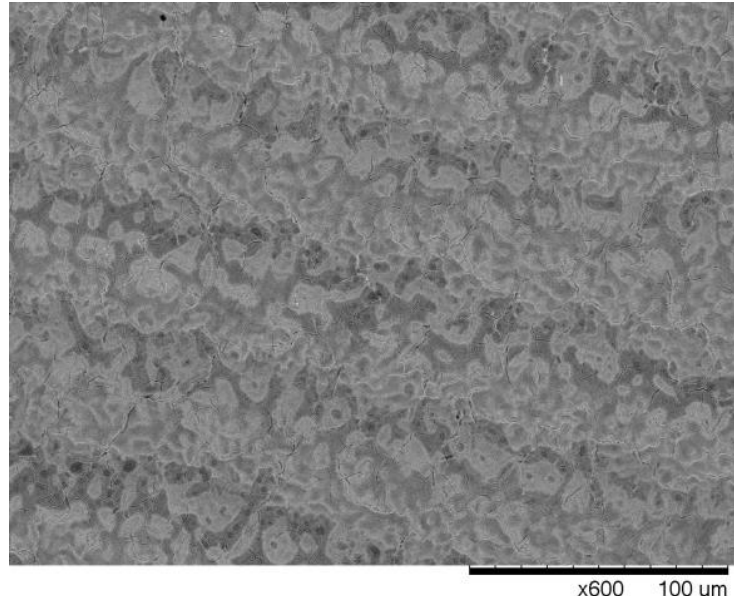

(a) Amostra 1

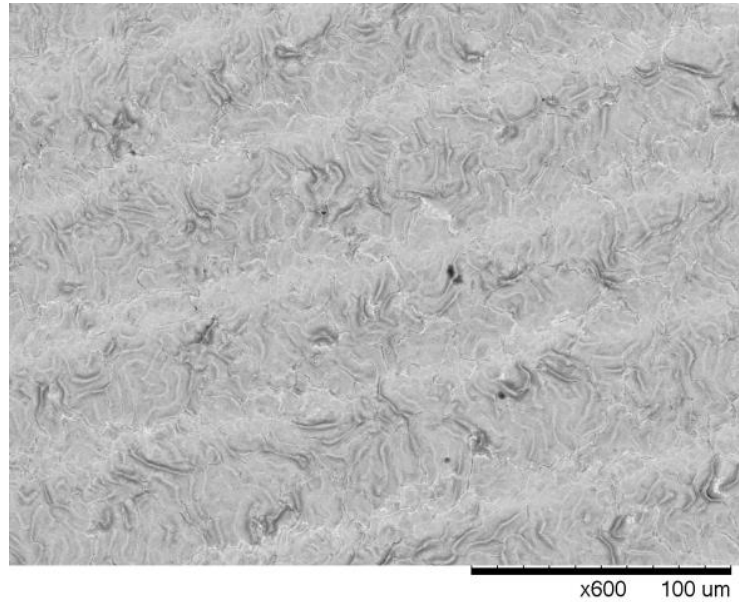

(c) Amostra 3

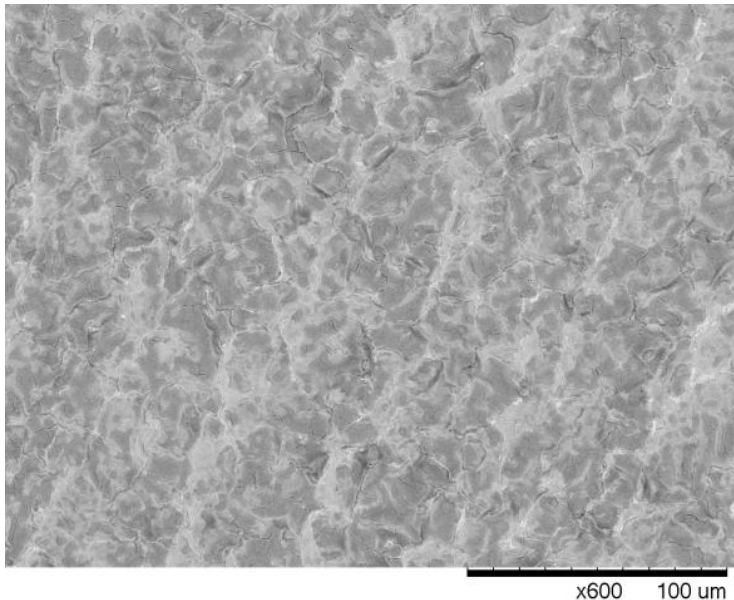

(b) Amostra 2

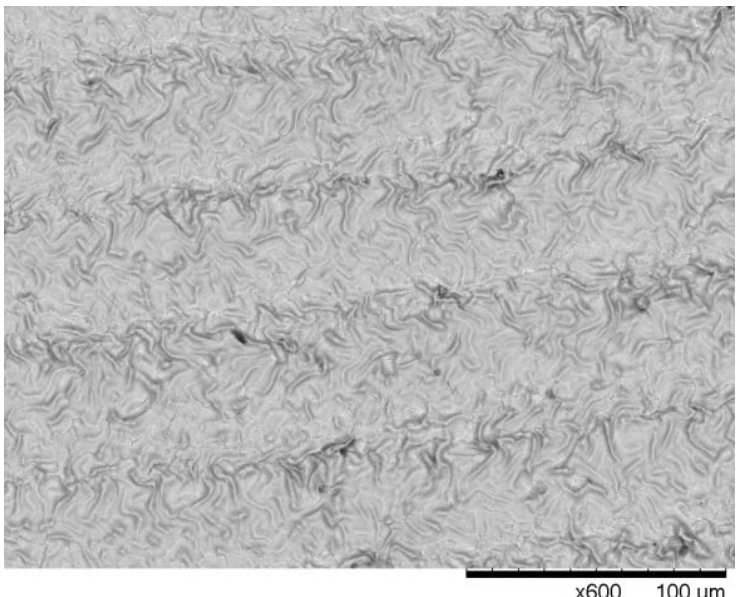

(d) Amostra 4

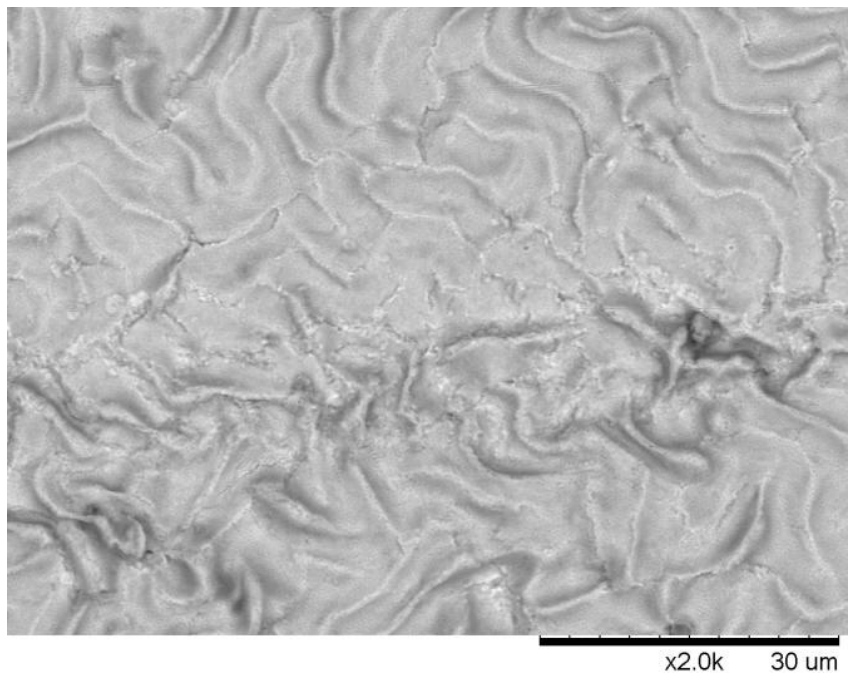

(e) Amostra 4

Figura 17. Imagens obtidas por MEV de baixo vácuo das superfícies do aço inoxidável ABNT NBR ISO 5832-1 após tratamento de texturização a laser e sem ataque. 
$\mathrm{Na}$ Figura 18, obtida por microscopia eletrônica de varredura (MEV) de baixo vácuo, é mostrada a superfície do aço inoxidável estudado sem tratamento a laser e sem ataque.

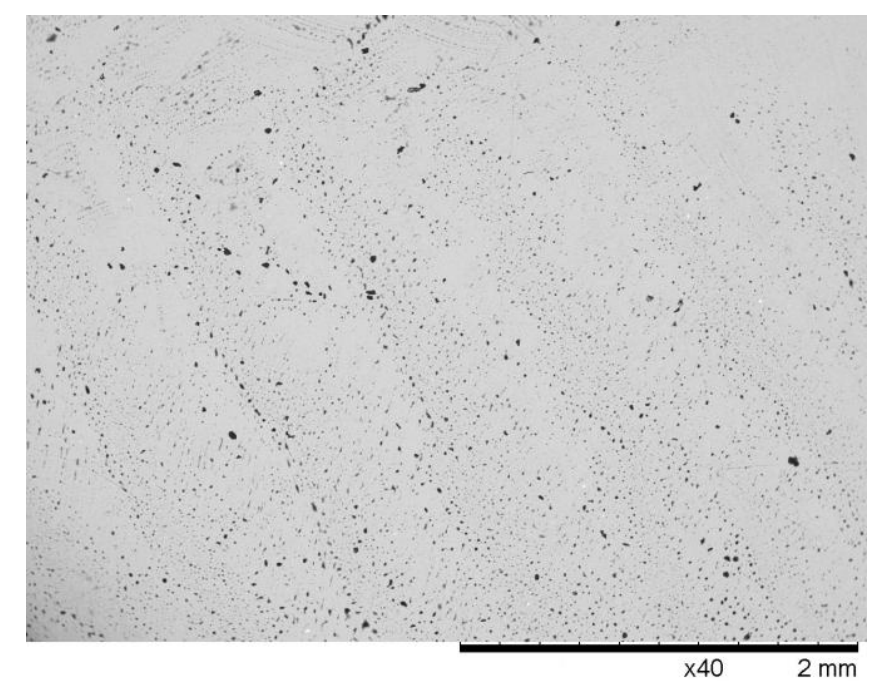

Figura 18. Imagem obtida por MEV de baixo vácuo da superfície do aço inoxidável como recebido, sem tratamento a laser e sem ataque. Aumento $40 \mathrm{x}$.

O tratamento de texturização, como citado em seções anteriores, consistiu na geração de linhas contínuas e paralelas justapostas umas às outras. Estas linhas que representam a trajetória por onde o feixe laser passou foram melhor visualizadas nas imagens da Figura 17 (a), (c) e (d), que correspondem ao tratamento de texturização com os parâmetros das amostras 1, 3, e 4. A imagem apresentada em (e), trata-se de ampliação com 2000 vezes de aumento da linha que corresponde à trajetória do feixe laser na amostra 4. O acabamento superficial de todas as amostras submetidas ao tratamento de texturização a laser apresentou microestrutura bruta de fusão.

As amostras que receberam marcações por feixe laser também tiveram suas superfícies examinadas. Nas Figuras 19 (a $-\mathrm{f}$ ), obtidas no mesmo equipamento, são apresentados aspectos da superfície deste biomaterial após a marcação do algarismo oito com os parâmetros citados.

O que diferencia estas imagens é o fato da marcação ser um tratamento mais localizado, ou seja, somente uma parte da superfície recebe este tipo de tratamento por laser. Deste modo, as amostras marcadas a laser apresentam superfícies com no mínimo três regiões distintas: 1) zona fundida pelo laser, 2) zona adjacente que é afetada termicamente e, 3) zona não - afetada pelo calor, 
distante da área de incidência do feixe onde a superfície é teoricamente a mesma do material padrão de referência.

As imagens seguintes foram geradas com diferentes aumentos após ataque em imersão em água régia, por $30 \mathrm{~s}$, onde é evidenciada a microestrutura austenítica do biomaterial de base, na região distante da incidência do laser.

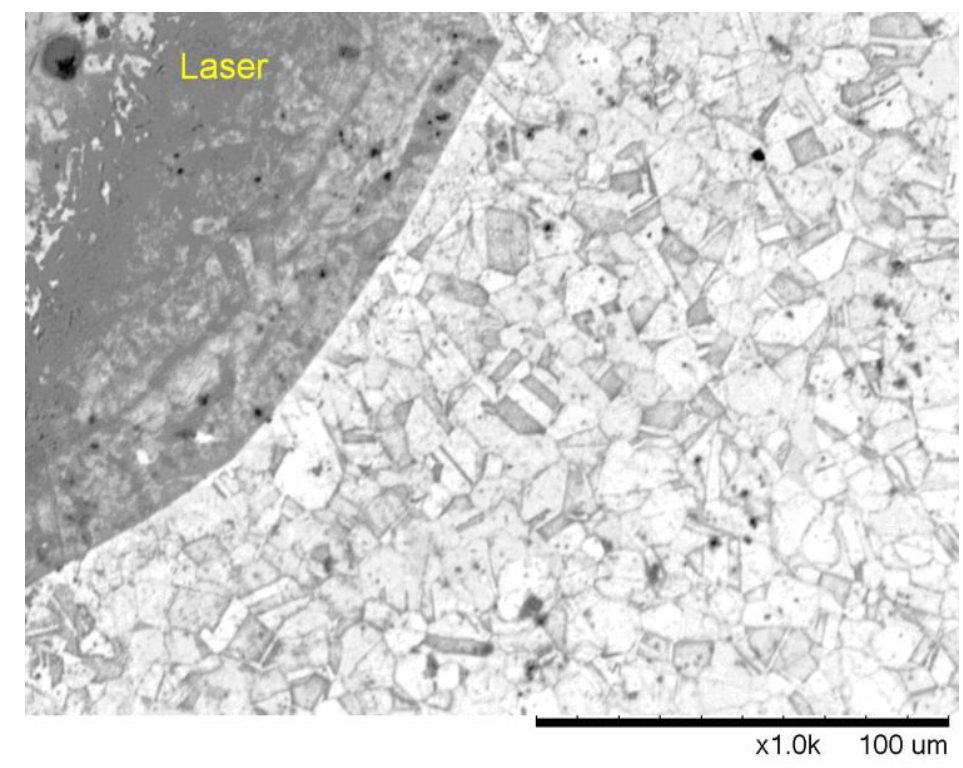

(a)

Figura 19 (a). Imagem da amostra 1 obtida por MEV da superfície do biomaterial após tratamento de marcação a laser. Ataque via água régia. Aumento $1000 \mathrm{x}$.

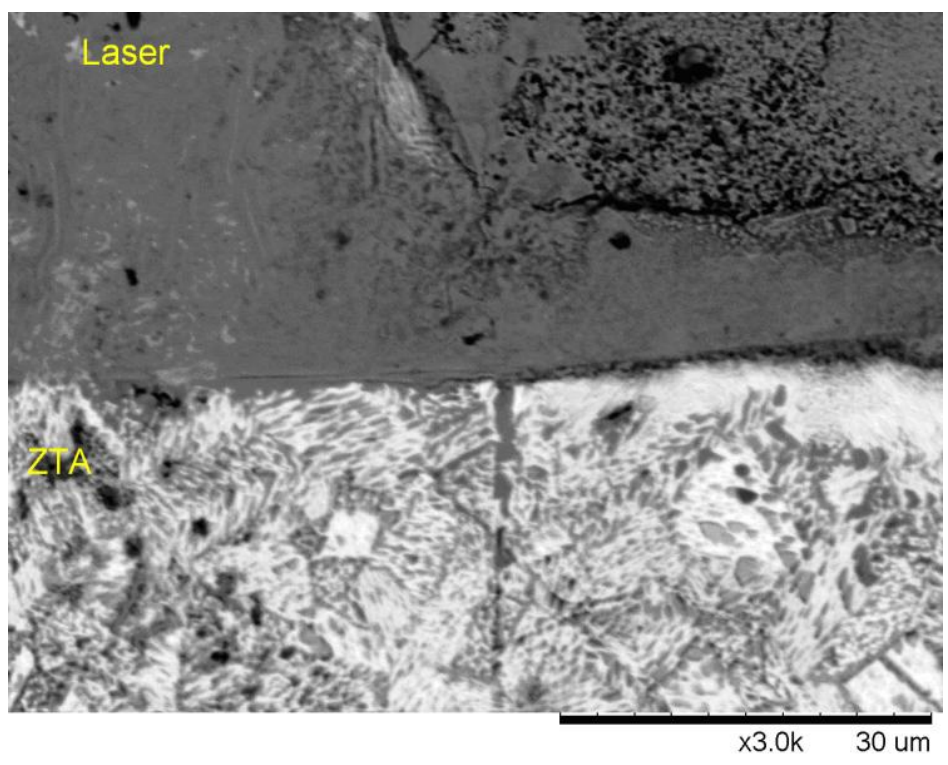

(b)

Figura 19 (b). Imagem da amostra 1 obtida por MEV da superfície do biomaterial após tratamento de marcação a laser. Ataque via água régia. Aumento 3000 x. 


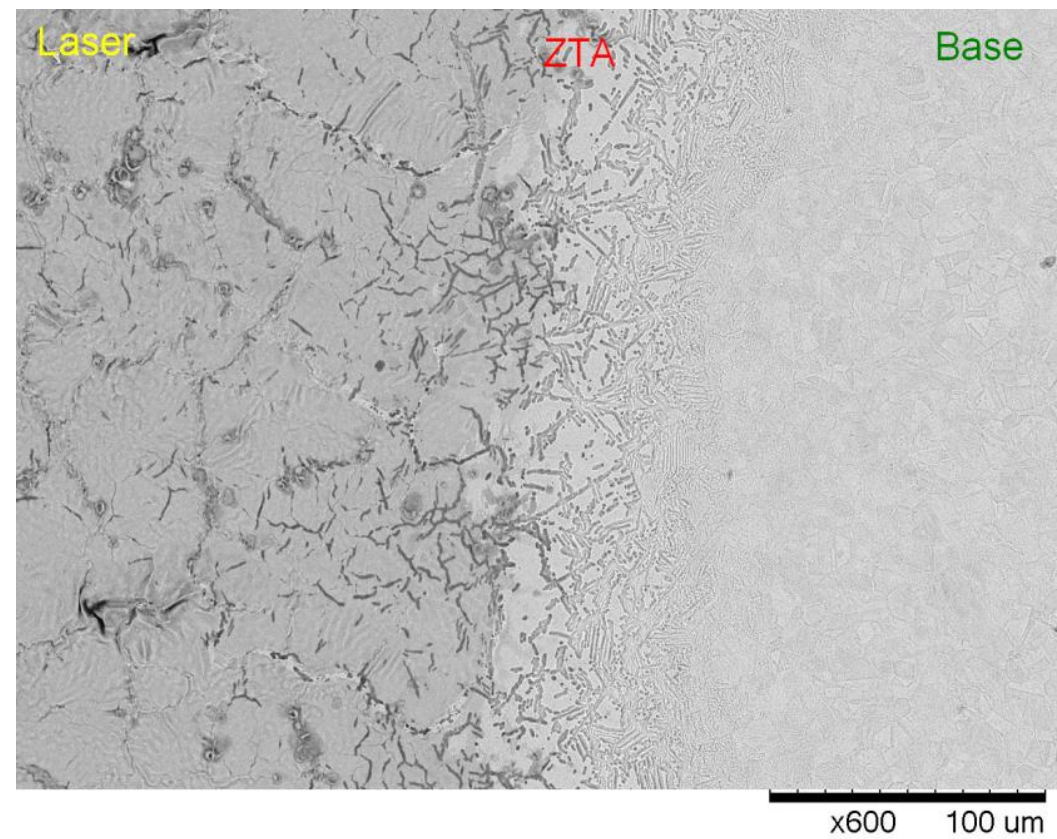

(c) Amostra -2. Aumento 600x.

Figura 19 (c). Imagem da amostra 2 obtida por MEV da superfície do aço inoxidável ABNT NBR ISO 5832-1 após tratamento de marcação a laser. Ataque via água régia. Aumento $600 \mathrm{x}$.

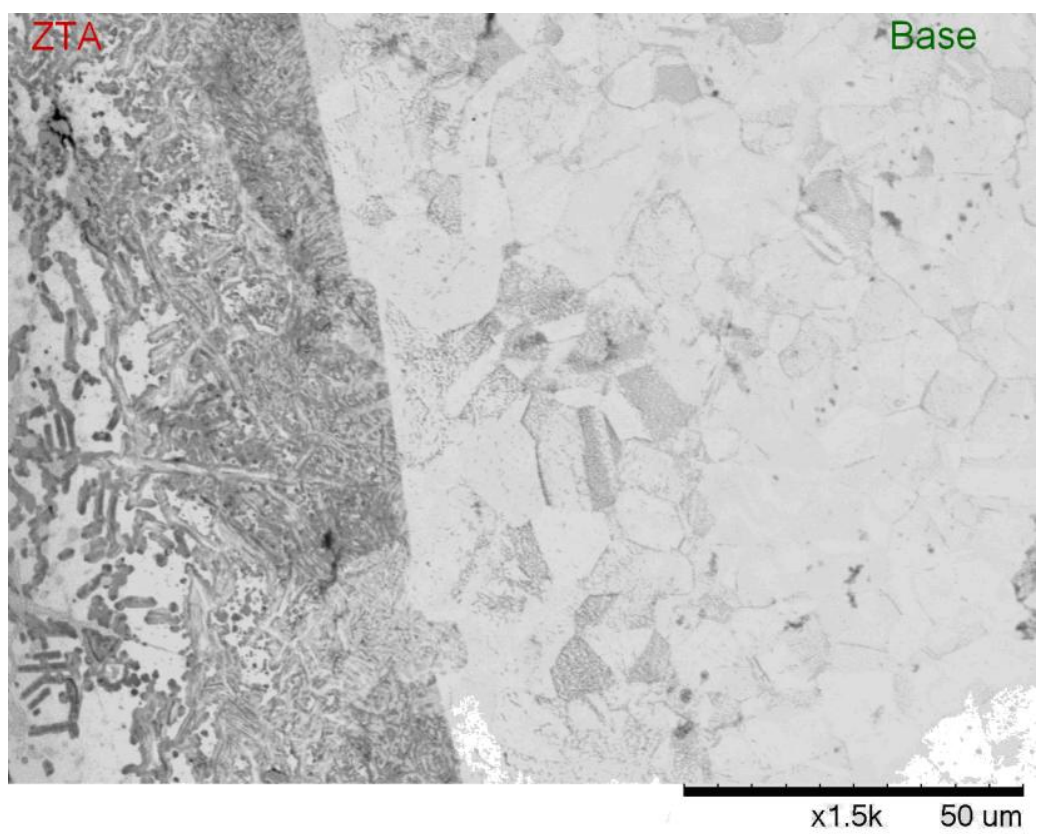

(d) Amostra -2. Aumento 1500x.

Figura 19 (d). Imagem da amostra 2 obtida por MEV da superfície do aço inoxidável ABNT NBR ISO 5832-1 após tratamento de marcação a laser. Ataque via água régia. Aumento $1500 \mathrm{x}$. 


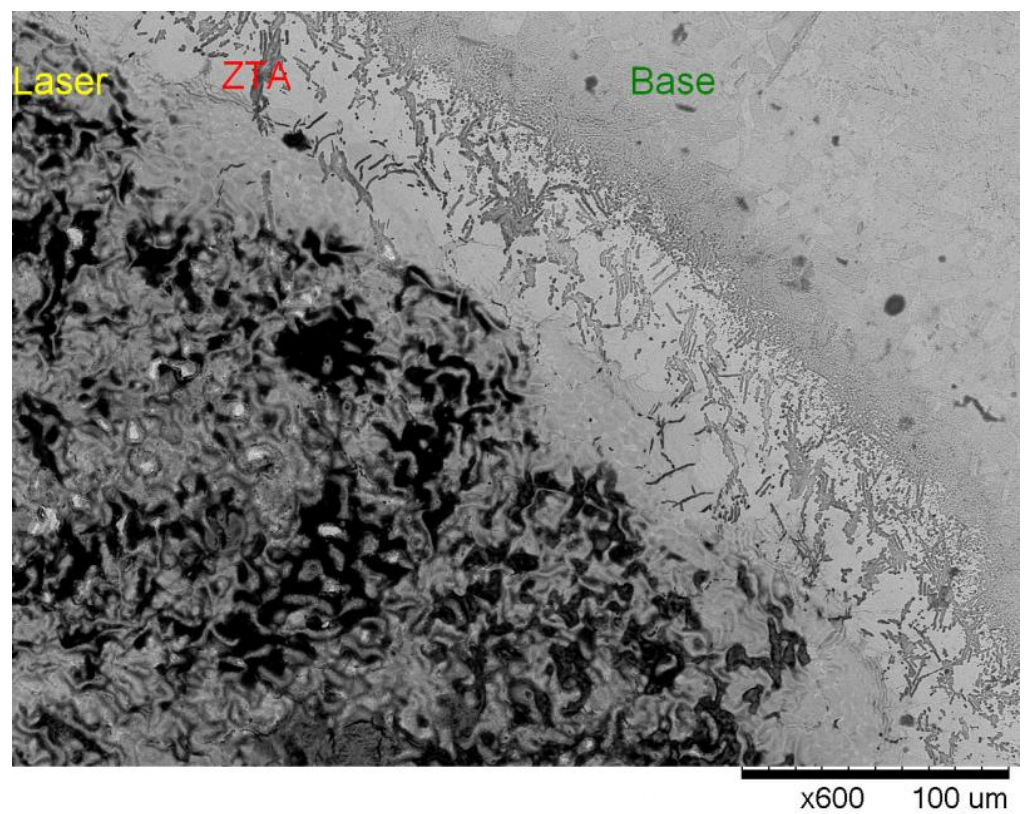

(e) Amostra -3. Aumento 600x.

Figura 19 (e). Imagem da amostra 3 obtida por MEV da superfície do aço inoxidável ABNT NBR ISO 5832-1 após tratamento de marcação a laser. Ataque via água régia. Aumento $600 \mathrm{x}$.

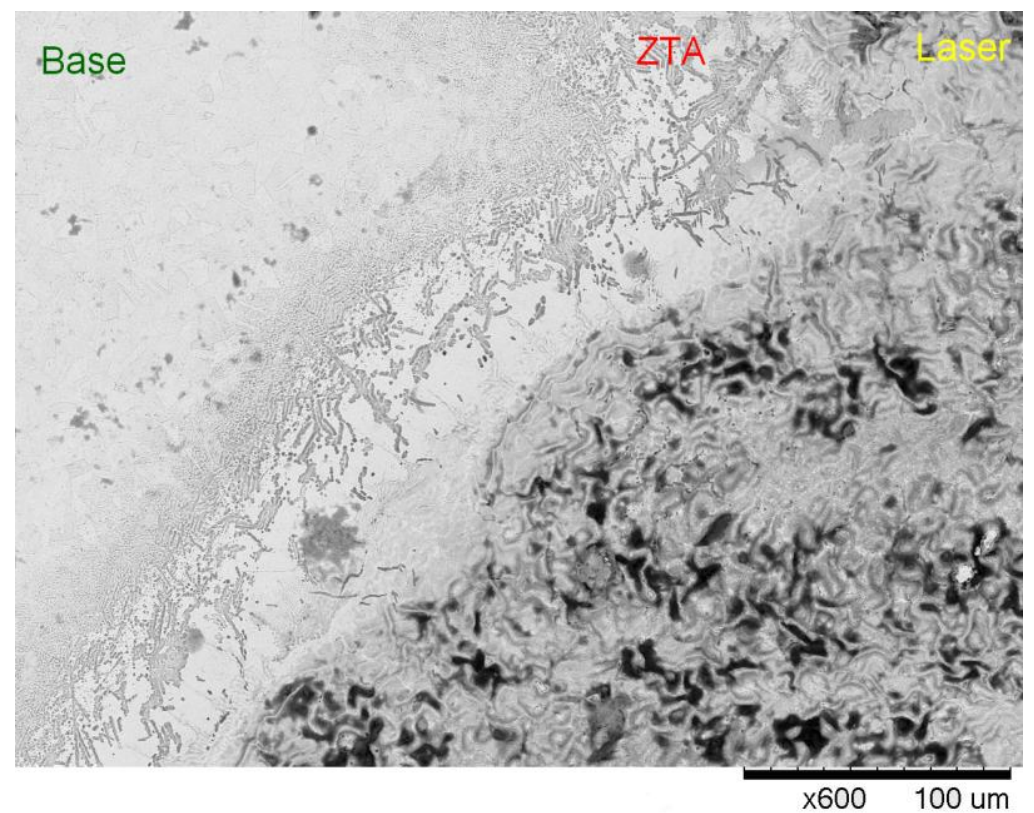

(f) Amostra -4. Aumento 600x.

Figura 19 (f). Imagem da amostra 4 obtida por MEV da superfície do aço inoxidável ABNT NBR ISO 5832-1 após tratamento de marcação a laser. Ataque via água régia. Aumento $600 x$.

A imagem da Figura 19 (b) é uma ampliação da região de transição entre a zona de fusão e a zona termicamente afetada (ZTA) para a amostra 1. Nota-se mudança microestrutural nestas regiões. A região de incidência do laser está mais escurecida devido à oxidação, uma vez que não houve atmosfera protetora. 
$\mathrm{Na}$ Figura 19 (c) está apresentada uma microestrutura com aumento de 600 vezes para a amostra 2. Nela estão bem diferenciadas as zonas fundida, afetada pelo calor e a zona correspondente ao material de base. Na Figura 19 (d) está apresentada uma ampliação de 1500 vezes para a amostra 2, evidenciando o material de base e a zona termicamente afetada pelo feixe laser. Nas Figuras 19 (e) e (f) são mostradas imagens com aumento de 600 vezes, evidenciando as transições entre as zonas fundida, afetada termicamente e 0 material de base para as amostras 3 e 4 , respectivamente.

Mudanças microestruturais e topográficas em razão de alterações em alguns parâmetros do feixe laser foram indentificadas por Lima et al. [82]. Eles utilizaram um laser Q-switched de Nd:YAG com diferentes frequências de pulso, na faixa de 1 a $50 \mathrm{kHz}$. Analogamente, realizaram tratamento de texturização que consistiu de linhas justapostas sobre a superfície do aço ferramenta AISI M2. Foram verificadas alterações nas energias e intensidades do feixe. Todas as condições utilizadas dentro desta faixa de frequências produziram fusão do metal. Eles notaram que houve pouca rugosidade para as baixas intensidades geradas pelo feixe, entretanto houve a formação de "crateras", ou seja, regiões com rugosidades elevadas para as intensidades maiores [82].

A superfície do aço inoxidável foi caracterizada utilizando-se a técnica de microscopia confocal, que possibilitou a verificação de transformações geradas pelo feixe laser. Também foram realizados ensaios de perfilometria e rugosidade para se determinar as profundidades, larguras, comprimentos e morfologias formadas de acordo com a variação dos parâmetros de texturização por feixe laser nas direções paralelas e perpendiculares à trajetória produzida pelo feixe sobre este biomaterial estudado.

Os resultados obtidos estão apresentados nas imagens da Figura 20 (a) a (e), Figura 21 (a) a (d) e nas Tabelas 8 e 9. 


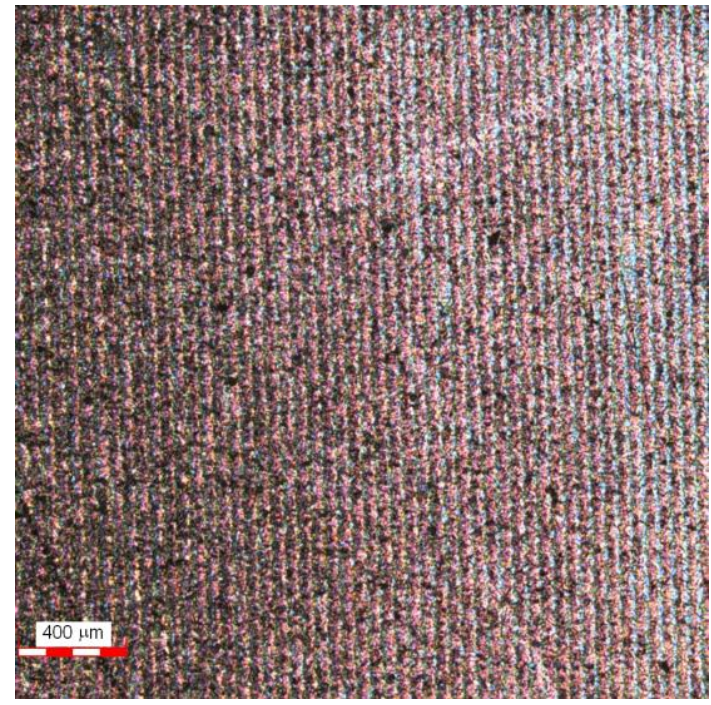

(a) Amostra 1

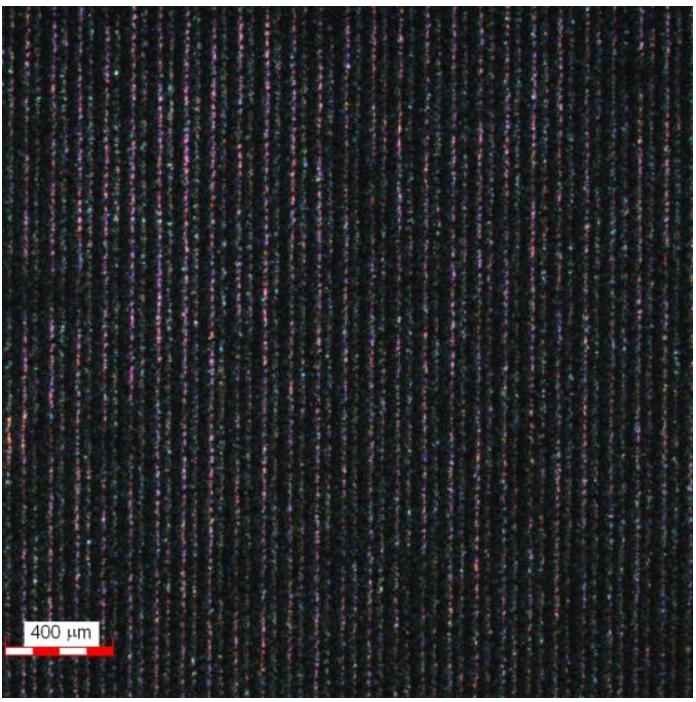

(c) Amostra 3

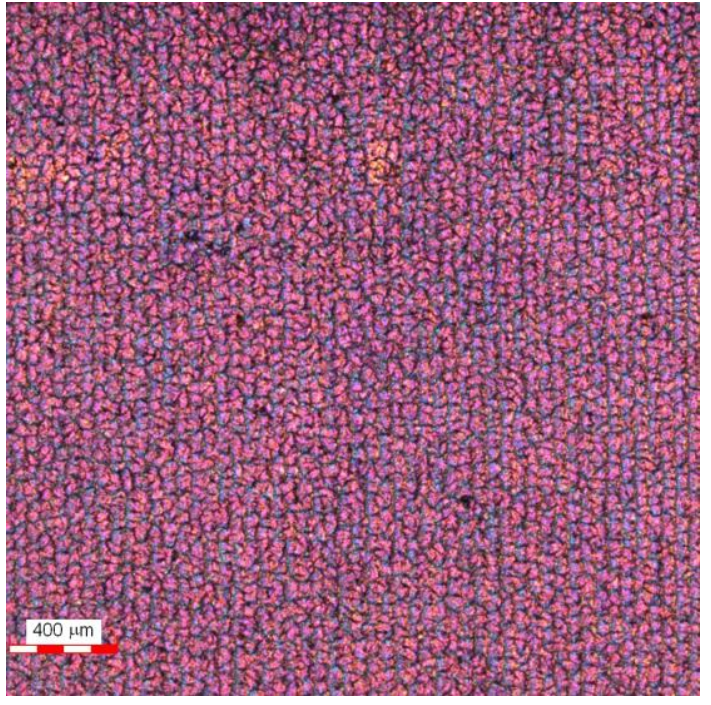

(b) Amostra 2

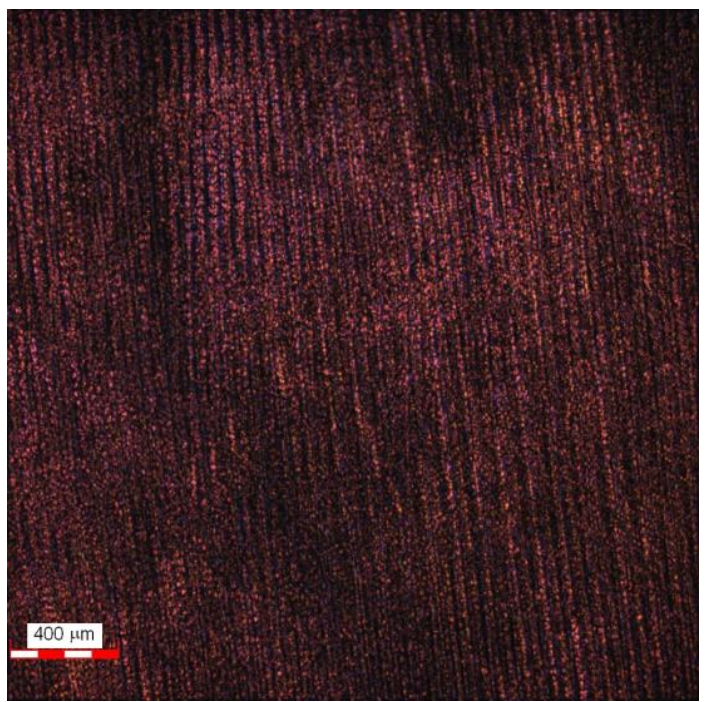

(d) Amostra 4

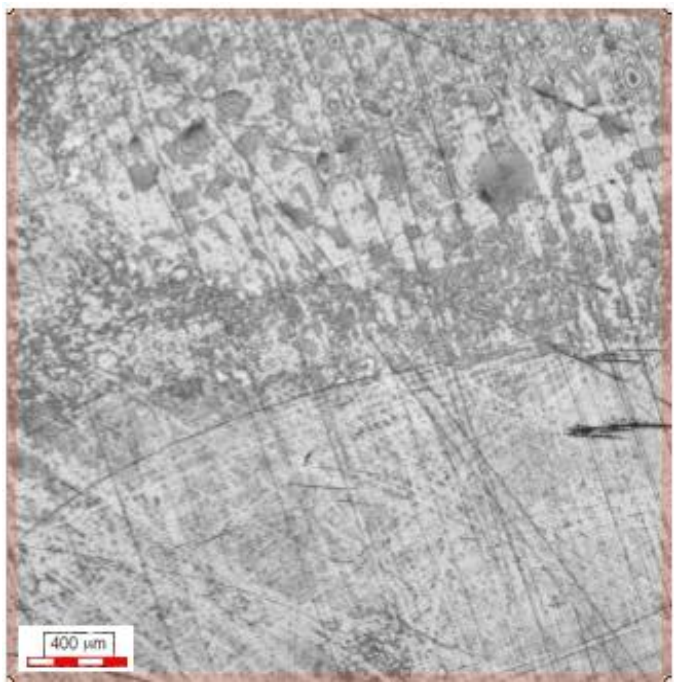

(e) Amostra padrão

Figura 20. Microscopia confocal das superfícies texturizadas a laser e padrão. 
Nota-se a mudança de colorações apresentadas nos óxidos formados sobre as superfícies texturizadas em razão da alteração da frequência dos pulsos do laser, conforme apresentado anteriormente nas imagens da Figura 13 (b).

De acordo com a técnica utilizada na inspeção visual da coloração e de aspectos como luminosidade, contraste, brilho e ângulo de posicionamento da lente têm-se variações nas tonalidades obtidas para a mesma condição de tratamento de texturização superficial. Este efeito encontra respaldo na literatura nos trabalhos publicados por Qi et al. [29] e Leone et al. [30].

Alguns perfis de rugosidades $(\mu \mathrm{m})$ tomados na direção perpendicular à trajetória do feixe laser para as amostras texturizadas, obtidos pela aplicação de ferramentas associadas à técnica de microscopia confocal, estão apresentados na Figura 21 (a) a (d).

$\mathrm{Na}$ Tabela 8 encontram-se os resultados obtidos para as médias das medições de rugosidades das amostras texturizadas. Para cada condição de texturização foram realizadas medidas paralelas à trajetória produzida pelo feixe e perpendiculares à mesma. Avaliando-se os valores obtidos para a rugosidade média $(\mathrm{Ra})$, nota-se pouca variação entre as direções paralela e perpendicular para cada amostra texturizada com frequências de $\mathrm{f}=80,188$, 296 e $350 \mathrm{kHz}$.

Isto pode ser explicado pelo fato de cada pulso produzido na superfície do aço ser extremamente coerente e localizado, fundindo a superfície em um único ponto, que após a solidificação produz um aspecto circular, sendo o diâmetro equivalente à largura gerada.

$\mathrm{Na}$ Tabela 9 estão as médias dos resultados de larguras e alturas dos tracejados que compuseram a texturização por laser, obtidos por perfilometria. As larguras medidas correspondem aos diâmetros dos pulsos do feixe laser, que foram diferentes em função da alternância de parâmetros. As alturas correspondem aos valores máximos de picos observados em relação à superfície do material de base, ou seja, região sem laser. 


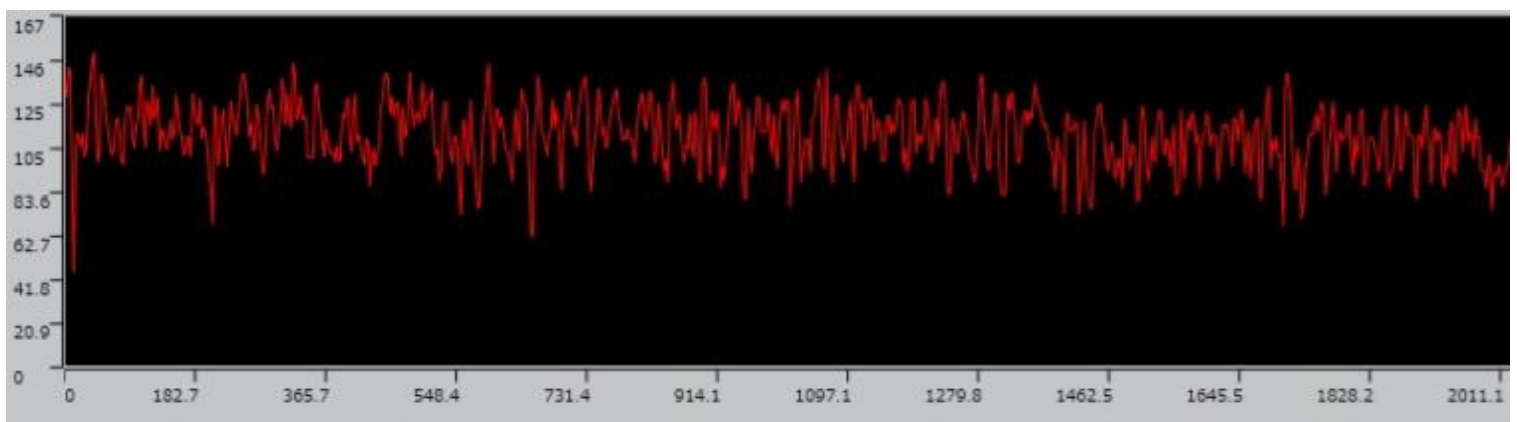

(a) Amostra texturizada -1 .

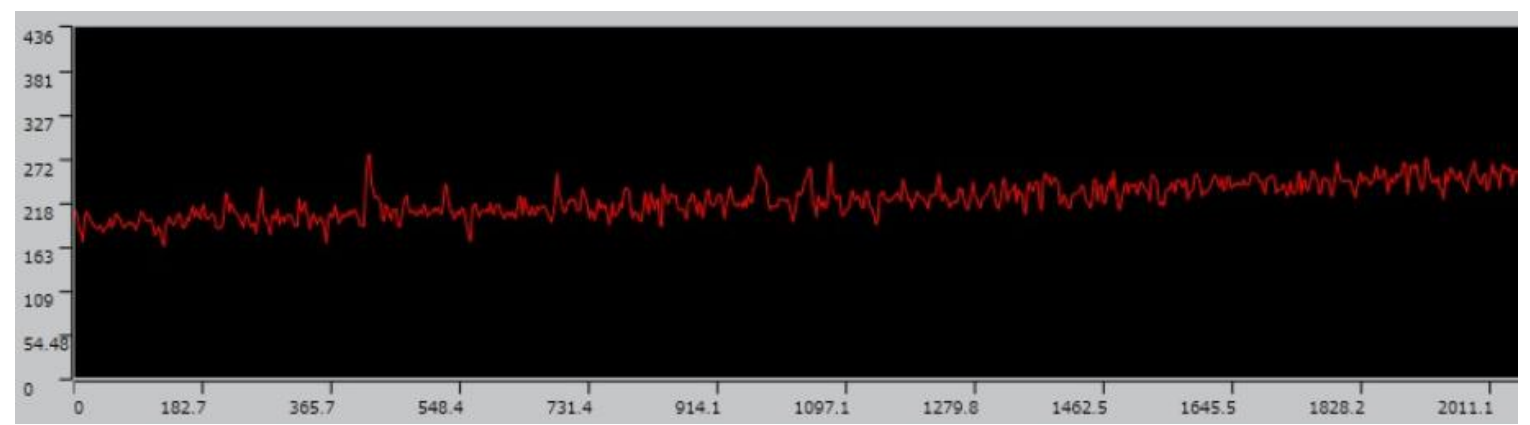

(b) Amostra texturizada -2.

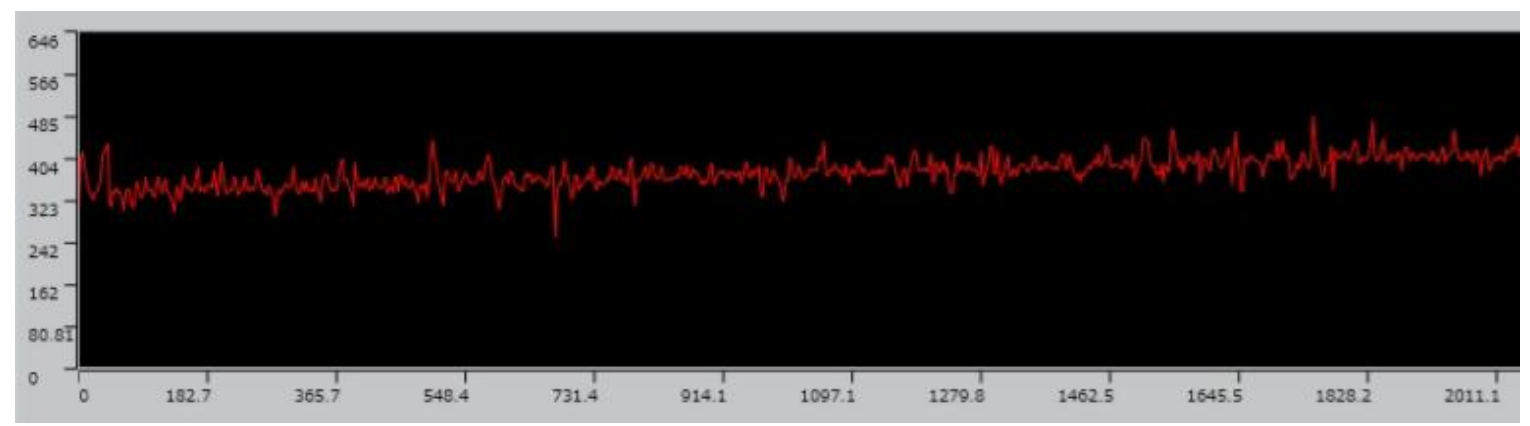

(c) Amostra texturizada -3.

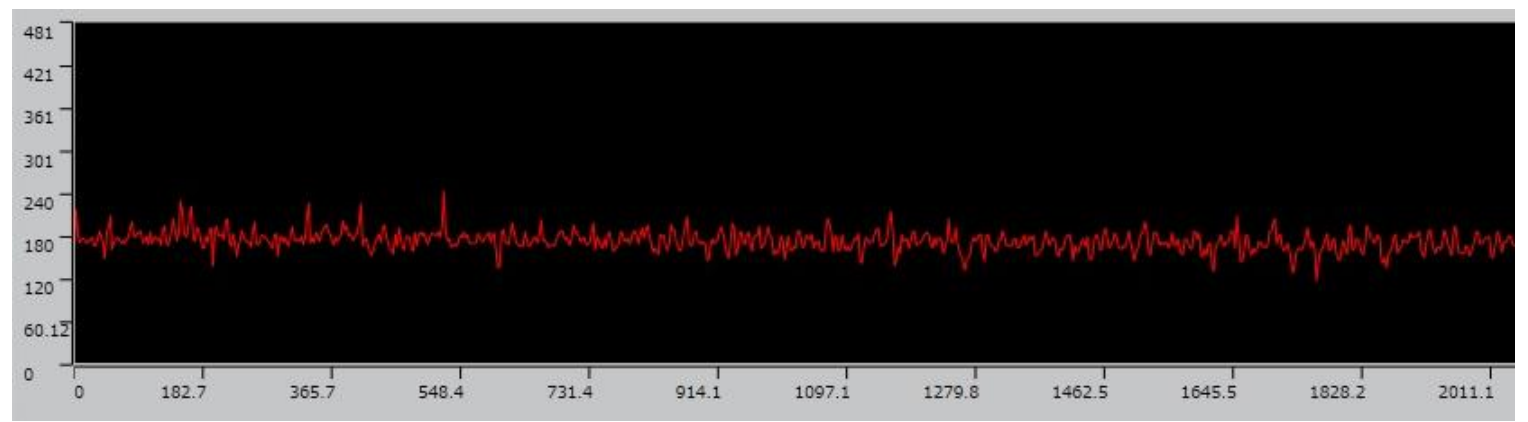

(d) Amostra texturizada -4.

Figura 21 (a), (b), (c), (d). Perfis de rugosidade das superfícies das amostras com texturização a laser. 
A Figura 22 é uma ampliação esquemática de uma região avaliada por perfilometria. A largura medida corresponde ao diâmetro do pulso efetivamente produzido na superfície de cada amostra.

Tabela 8. Rugosidades para as amostras texturizadas a laser nas direções paralelas e perpendiculares à trajetória produzida pelo feixe.

\begin{tabular}{c|c|c|c}
\hline Amostras & $\mathrm{Ra}(\mu \mathrm{m})$ & $\mathrm{Rz}(\mu \mathrm{m})$ & $\mathrm{Rq}(\mu \mathrm{m})$ \\
\hline 1-paralela & 5,2 & 53,2 & 6,7 \\
\hline 1-perpendicular & 4,9 & 46,1 & 6,2 \\
\hline 2-paralela & 1,5 & 32,6 & 2,8 \\
\hline 2-perpendicular & 1,0 & 29,5 & 2,1 \\
\hline 3-paralela & 11,2 & 116,4 & 15,0 \\
\hline 3-perpendicular & 13,8 & 389,8 & 23,4 \\
\hline 4-paralela & 11,5 & 113,4 & 15,1 \\
\hline 4-perpendicular & 12,4 & 249,1 & 18,4 \\
\hline
\end{tabular}

Alguns pesquisadores [82] sugerem que a rugosidade superficial é interessante para o aumento da aderência, principalmente relacionada a revestimentos e em ligas de materiais similares, e pode ser produzida e ajustada por feixe laser. Este efeito é desejável nas superfícies de alguns biomateriais para dispositivos médicos de fixação permanente.

Tabela 9. Valores médios das larguras dos tracejados produzidos pelo feixe laser, obtidos por perfilometria, para as amostras texturizadas.

\begin{tabular}{c|c|c}
\hline Amostras & Largura $(\mu \mathrm{m})$ & Altura $(\mu \mathrm{m})$ \\
\hline 1 & 50,0 & 15,5 \\
\hline 2 & 47,0 & 34,5 \\
\hline 3 & 45,0 & 33,0 \\
\hline 4 & 38,0 & 36,5 \\
\hline
\end{tabular}

De modo geral, as amostras das superfícies tratadas com as menores frequências, produziram as maiores larguras e as menores alturas. Entretanto, com o aumento da frequência de pulso do laser, notou-se a produção de larguras inferiores. 


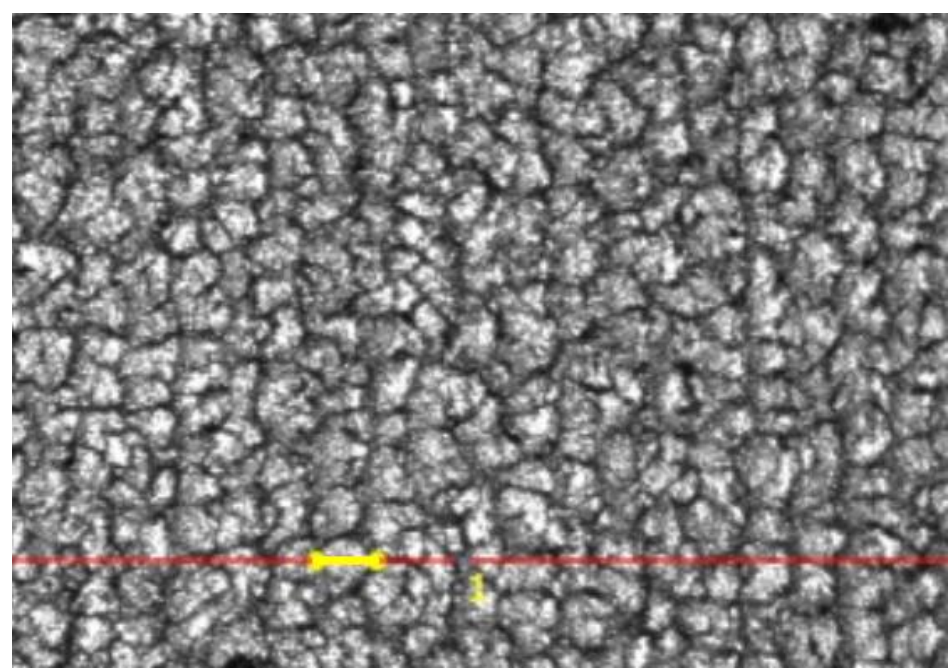

Figura 22. Ampliação esquemática da região analisada por perfilometria (linha amarela). Largura dos tracejados produzidos na texturização por feixe laser.

Obtendo-se os valores dos diâmetros dos pulsos efetivamente produzidos sobre as superfícies das amostras dos biomateriais estudados foi possível calcular vários parâmetros do feixe laser que comprovam o comportamento encontrado nas análises de microdureza e rugosidade. Parâmetros comentados em seções anteriores, tais como: energia do pulso, tempo de duração de cada pulso, diâmetro, área, peak power, intensidade e fluência foram calculados e os resultados obtidos estão apresentados na Tabela 10.

Tabela 10. Valores dos principais parâmetros do feixe laser calculados para cada condição de acabamento superficial.

\begin{tabular}{c|c|c|c|c|c|c}
\hline Amostra & $\begin{array}{c}\text { Frequência } \\
{[\mathrm{kHz}]}\end{array}$ & $\begin{array}{c}\text { Energia } \\
{[\mu \mathrm{J}]}\end{array}$ & $\begin{array}{c}\text { Área } \\
{\left[\mathrm{cm}^{2}\right]}\end{array}$ & $\begin{array}{c}\text { Fluência } \\
{\left[\mathrm{J}_{\mathrm{cm}}-2\right]}\end{array}$ & $\begin{array}{c}\text { Peak Power } \\
{[\mathrm{W}]}\end{array}$ & $\begin{array}{c}\text { Intensidade } \\
{\left[\mathrm{W} . \mathrm{cm}^{-2}\right]}\end{array}$ \\
\hline 1 & 80 & 625,0 & $1,96 \times 10^{-9}$ & $318.390,0$ & $3.742,5$ & $1,9 \times 10^{12}$ \\
\hline 2 & 188 & 266,0 & $1,70 \times 10^{-9}$ & $156.470,5$ & $6.650,0$ & $3,9 \times 10^{12}$ \\
\hline 3 & 296 & 169,0 & $1,60 \times 10^{-9}$ & $105.625,0$ & $7.348,0$ & $4,6 \times 10^{12}$ \\
\hline 4 & 350 & 143,0 & $1,13 \times 10^{-9}$ & $126.102,0$ & $7.150,0$ & $6,3 \times 10^{12}$ \\
\hline
\end{tabular}

Os valores apresentados na Tabela 10 foram calculados para cada amostra em razão da alteração do parâmetro frequência dos pulsos do feixe laser. A potência média do equipamento de laser utilizado foi de 50 watts, como mencionado na seção de Materiais e Métodos. Como a frequência dos pulsos segue uma relação inversamente proporcional à energia do feixe [27]; obteve-se, 
como esperado, a diminuição da energia em função do aumento da frequência, respectivamente, para as amostras tratadas nas condições de 1 a 4.

As áreas obtidas foram calculadas utilizando-se os valores de diâmetros efetivamente medidos sobre as superfícies das amostras tratadas por feixe laser, via microscopia confocal, no modo perfilometria. Nota-se diminuição das áreas calculadas para os pulsos em razão do aumento da frequência dos pulsos; ou seja, a diminuição das áreas está diretamente ligada à diminuição das energias e aumento da frequência para cada condição de superfície avaliada [27, 28].

A Figura 23 é uma representação das energias calculadas para cada amostra em função dos diâmetros dos pulsos medidos por microscopia. Percebese uma relação diretamente proporcional entre diâmetro e energia de pulso e, inversamente proporcional às frequências de pulso utilizadas nos tratamentos.

Este efeito foi evidenciado por Stašić et al. [81] em texturizações a laser realizadas sobre o aço carbono AISI 1045, com laser de fibra óptica pulsado de Ti:Safira, de femtossegundos alterando-se as energias de pulso. Eles calcularam os diâmetros por perfilometria e avaliaram mudanças na morfologia das superfícies deste aço por microscopia óptica e eletrônica. A alteração da energia provocou mudanças na morfologia das superfícies. Eles destacam uma relação direta entre o aumento da energia e o aumento do diâmetro dos pulsos.

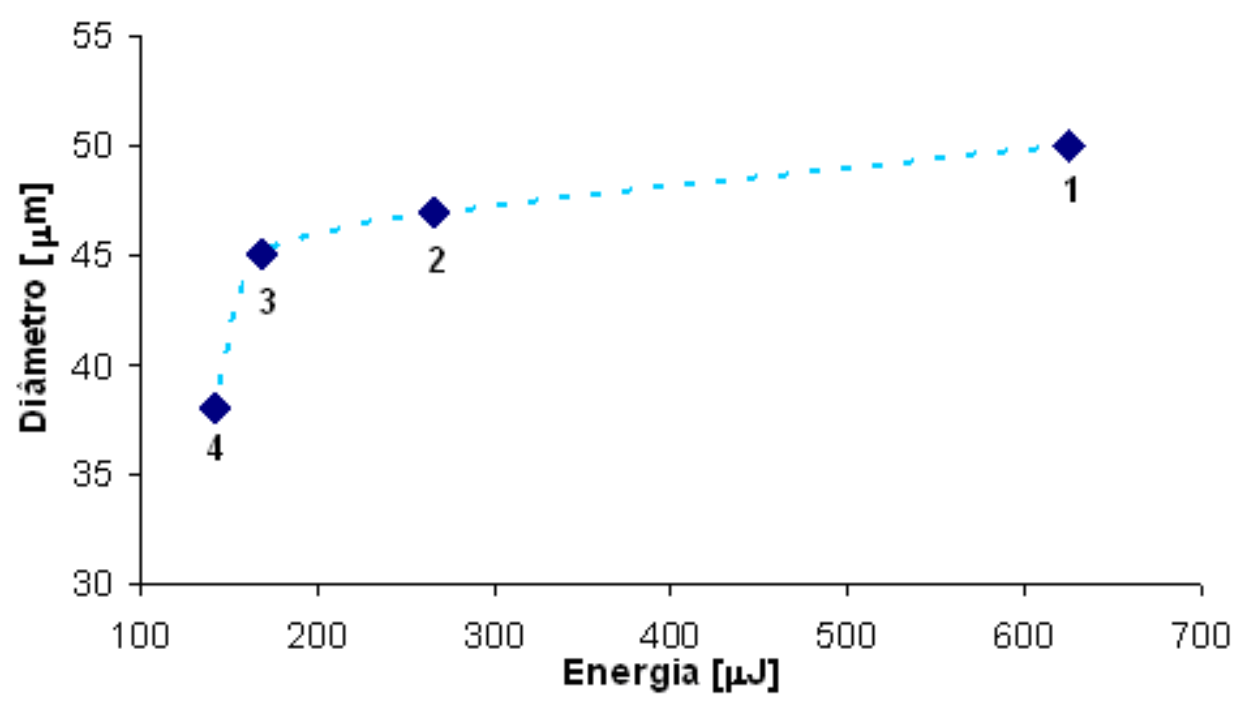

Figura 23. Diagrama de diâmetros em função de energia dos pulsos para cada condição avaliada. Os valores de 1 a 4 referem-se às amostras. 
Na Figura 24 estão apresentados os valores das intensidades [W.cm²] calculadas em função da duração de cada pulso [ns], para as amostras de 1 a 4. Nota-se que para as amostras marcadas e texturizadas com as menores frequências, por exemplo, a amostra $1 \mathrm{com} f=80 \mathrm{kHz}$, obtiveram-se pulsos mais longos, da ordem de 167 ns e, com menores intensidades. Entretanto, para as amostras tratadas com as maiores frequências, amostra 4, por exemplo, foram obtidos pulsos mais curtos de cerca de 20 ns e com intensidades da ordem $6,3 \times 10^{12}$ W.cm ${ }^{-2}$.

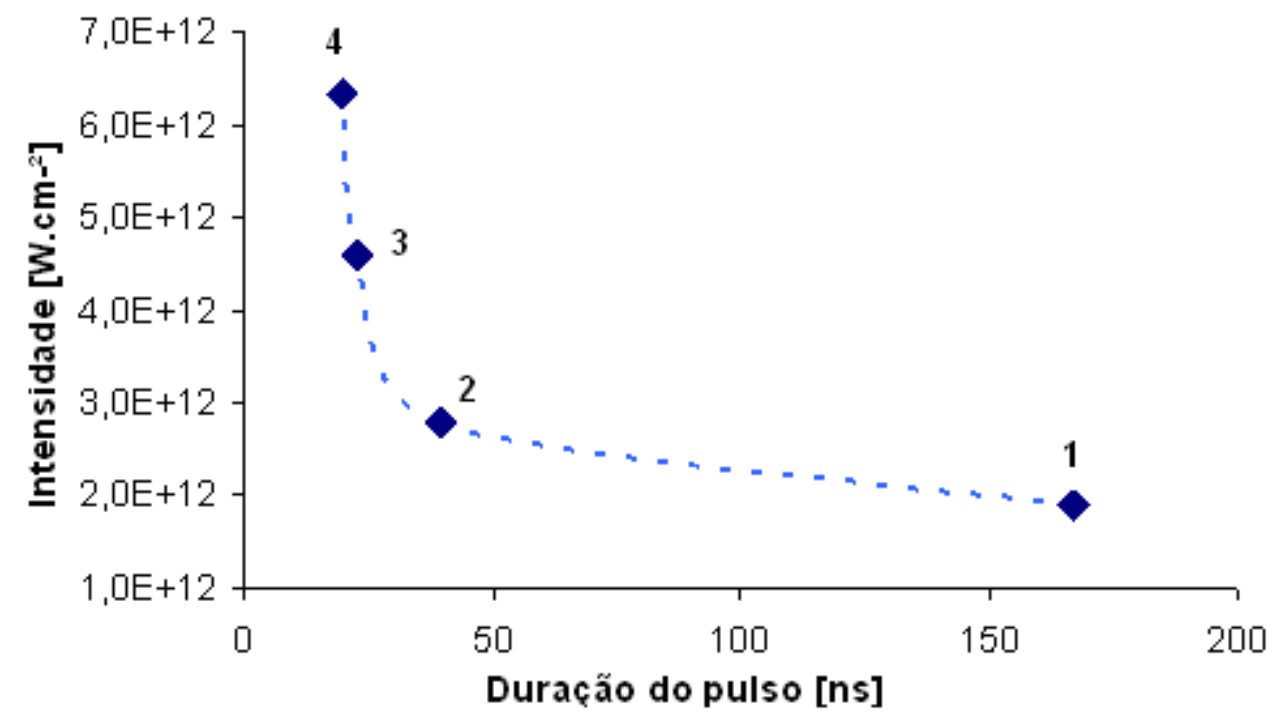

Figura 24. Diagrama de intensidades em função do tempo dos pulsos para cada condição avaliada. Os valores de 1 a 4 referem-se à amostra.

Comportamento análogo ao mostrado na Figura 24 foi obtido por Ki e So [83] em trabalho de elaboração de mapas de processamento de tratamentos térmicos em aços carbono AISI 1020 e 1035, por laser bombeado por diodo; onde foram obtidas maiores intensidades sobre as superfícies que receberam a incidência do feixe por períodos mais curtos.

\subsection{Difração de Raios X}

A técnica de difração de raios $X$ foi utilizada a fim de se averiguar se houve mudança de arranjo cristalográfico devido à ação do feixe laser nas amostras marcadas e texturizadas comparando-as com o material de referência. Entretanto 
isto não foi observado, pois os espectros obtidos apresentaram as mesmas orientações para os picos independentemente do tipo de tratamento superficial utilizado nas amostras deste biomaterial.

Isto pode ser explicado pelo fato de que esta técnica avalia uma fração de material relativamente grande em comparação com a área e o volume efetivamente modificado pelo feixe laser. As superfícies marcadas pelo laser possuem esta gravação somente em locais predefinidos, restando grande parte das superfícies das amostras sem marcação e, uma pequena área destas superfícies de zona afetada pelo calor; já as amostras texturizadas pelo laser possuem toda a área superficial preenchida por linhas justapostas, entretanto este efeito é em algumas amostras da ordem de poucos micrômetros.

Como nesta técnica o feixe de raios $X$ penetra no material analisado, o que foi possível de se analisar foi o material de base, comum para todas as condições. Não foi possível o uso de técnicas mais localizadas como microdifração de raios $X$ ou difração de raios $X$ com ângulo rasante.

\subsection{Textura}

A textura deste biomaterial com tratamento por feixe laser foi avaliada em equipamento descrito anteriormente. $O$ tratamento a laser não alterou significativamente a textura das amostras deste biomaterial em comparação com a amostra padrão. Na Figura 25 estão apresentados resultados para a condição padrão, os resultados obtidos para as demais condições não estão apresentados por mostrarem as mesmas características.

As figuras de pólo foram geradas em 15 níveis e estão apresentadas na ordem dos planos (111), (220), e (200), respectivamente. 

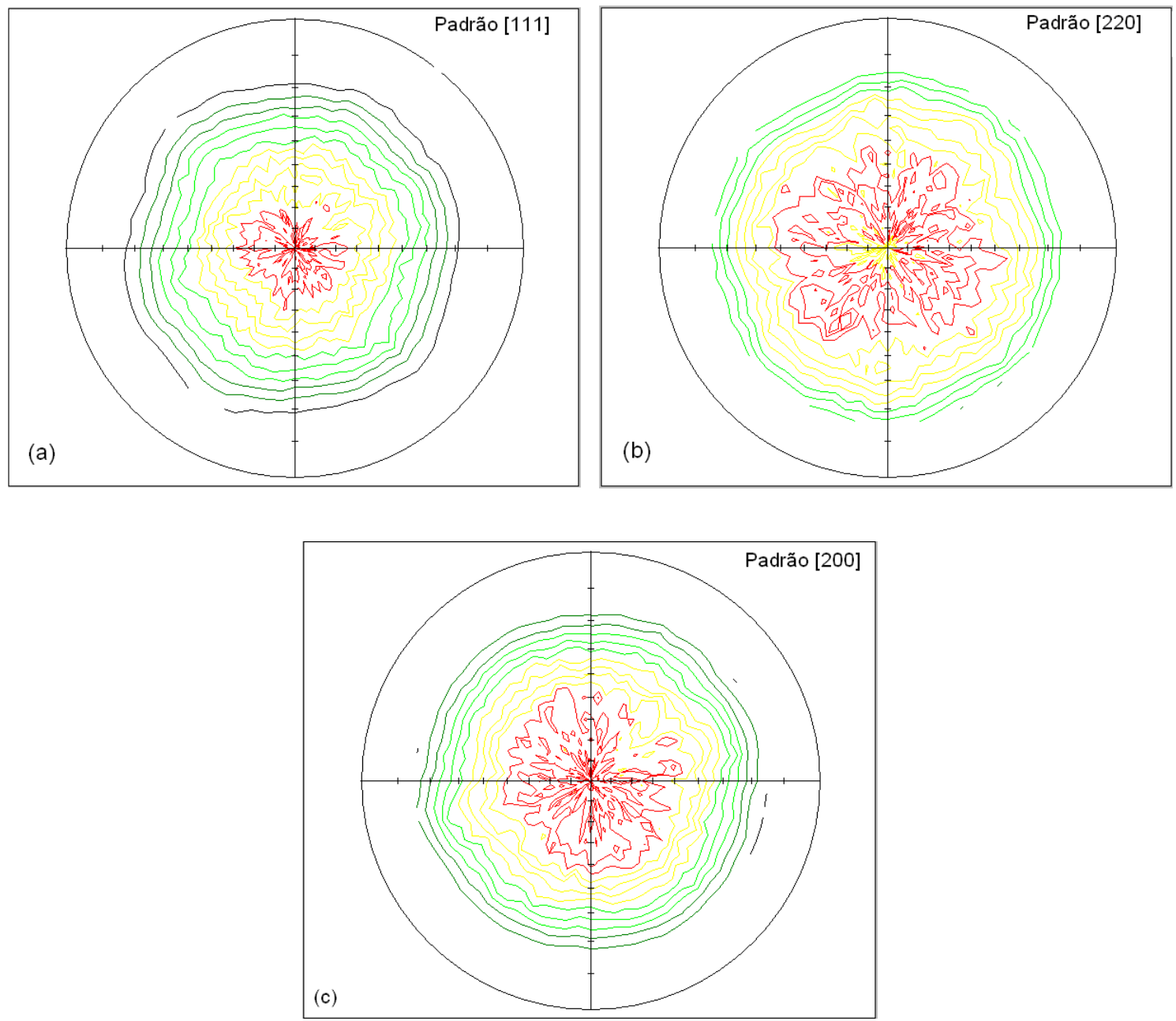

Figura 25. Figuras de pólo para as amostras na condição padrão para os planos:

(a) (111), (b) (220) e (c) (200).

\subsection{Técnica Eletroquímica de Varredura com Eletrodo Vibrante (SVET)}

O efeito causado pelo feixe laser nas superfícies das amostras do aço inoxidável austenítico ABNT NBR ISO 5832-1, tratadas por texturização e marcação foi averiguado por ensaios de varredura com eletrodo vibrante (SVET). Com a utilização desta técnica foi possível a determinação das áreas onde se encontravam as maiores densidades de corrente de corrosão, evidenciando perfeitamente as zonas anódicas e catódicas.

Todas as medidas foram realizadas em potencial de circuito aberto (PCA). A resistividade da solução de PBS foi medida antes dos ensaios e apresentou um 
valor de 63 ohm.cm. Utilizou-se resina epóxi para criar uma janela de análise e isolar apenas um número "8".

Na Figura 26 (a) é mostrada uma imagem obtida por microscopia óptica do local selecionado para análise por SVET, correspondente à região da marcação do algarismo oito, com os parâmetros pré definidos para a amostra 1. Nas Figuras 26 (b), (c), (d), (e) e (f) estão apresentados os mapas obtidos em função do tempo de imersão, que variou de 0 até 24 horas, no PCA.

A barra de escalas, na lateral direita de cada mapa obtido por SVET, refere-se à distribuição de correntes de corrosão, sendo as maiores correntes (anódicas), representadas pela cor vermelha e, as menores correntes (catódicas), representadas pela cor azul.

Analisando-se a Figura 26, correspondente à amostra 1, marcada com a menor frequência de pulso $(80 \mathrm{kHz})$, nota-se a presença de sítios anódicos relacionados às regiões com marcação a laser nos primeiros tempos de imersão no PCA, imagens: (b), (c) e (d); após períodos superiores a 17 horas de imersão, imagens (e) e (f), os sítios anódicos praticamente desapareceram, sendo obtidos mapas com densidades de correntes catódicas, o que sugere um crescimento, mesmo que mínimo, do filme passivo nestas condições.

Efeito semelhante foi encontrado em pesquisas anteriores envolvendo o mesmo biomaterial marcado por feixe laser com parâmetros industriais [1, 3], onde após estes tempos de imersão o crescimento do filme passivo dificulta a visualização da distribuição de áreas anódicas e catódicas nas amostras. Estas podem se tornar mais claramente reveladas sob condições mais agressivas, como por exemplo, polarizando-se as amostras.

O comportamento apresentado na Figura 26, referente a amostra 1, não foi observado para todas as condições de marcação a laser. $O$ que sugere que o parâmetro alternado, ou seja, a frequência do pulso produz filmes passivos com propriedades protetoras diferentes.

Na Figura 27 está apresentada a mesma sequência de imagens para a amostra 2, marcada com frequência de pulsos $\mathrm{f}=188 \mathrm{kHz}$. 


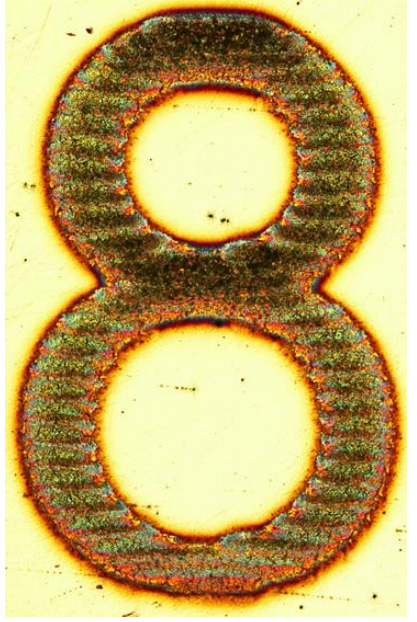

(a) Microscopia óptica antes do ensaio.
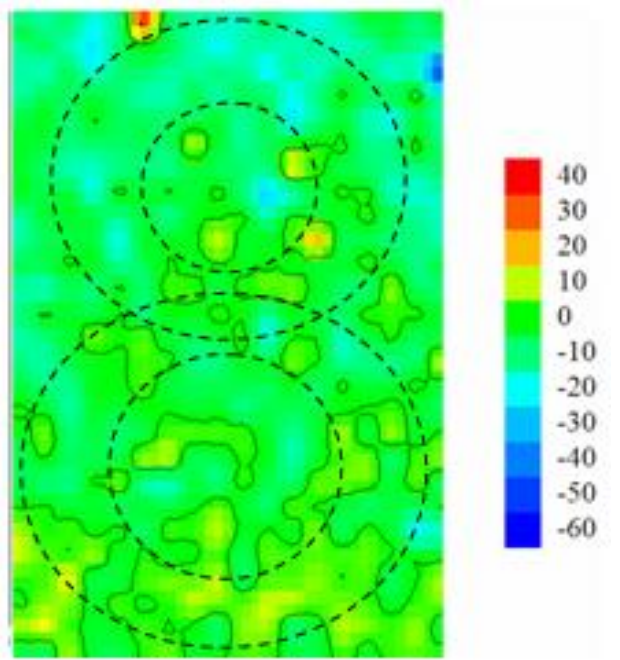

(c) Mapa 2: $\mathrm{t}_{\text {inicial }}=1 \mathrm{~h} 30 \mathrm{~min} ; \mathrm{t}_{\text {final }}=1 \mathrm{~h} 36 \mathrm{~min}$.
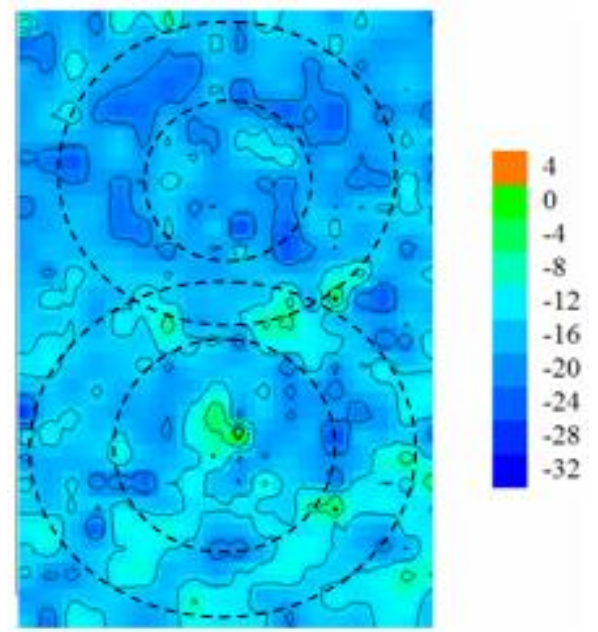

(e) Mapa 4: $\mathrm{t}_{\text {inicial }}=17 \mathrm{~h} ; \mathrm{t}_{\text {final }}=17 \mathrm{~h} 06 \mathrm{~min}$

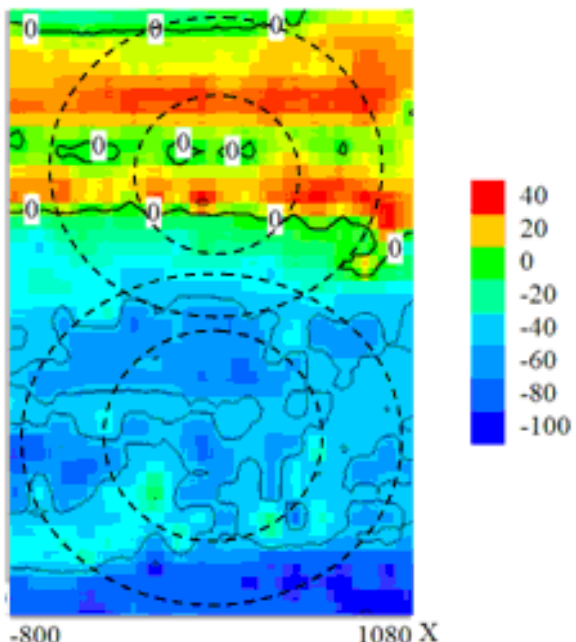

(b) Mapa 1: $\mathrm{t}_{\text {inicial }}=0 \mathrm{~min} ; \mathrm{t}_{\text {final }}=6 \mathrm{~min}$.

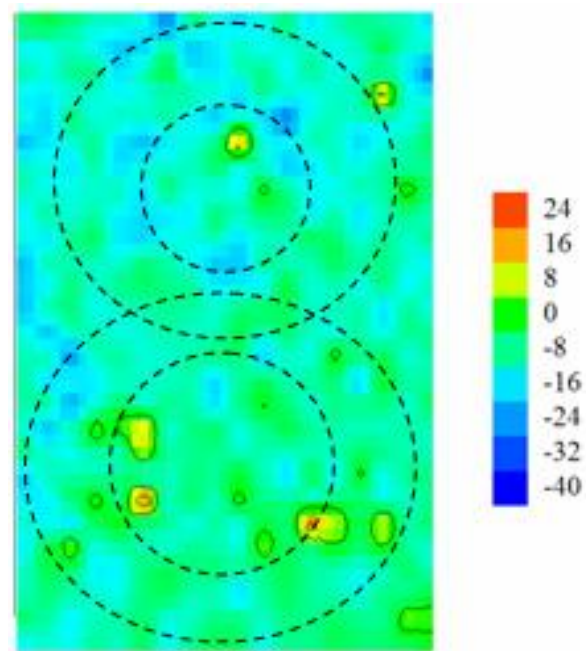

(d) Mapa 3: $\mathrm{t}_{\text {inicial }}=2 \mathrm{~h} ; \mathrm{t}_{\text {final }}=2 \mathrm{~h} 06 \mathrm{~min}$
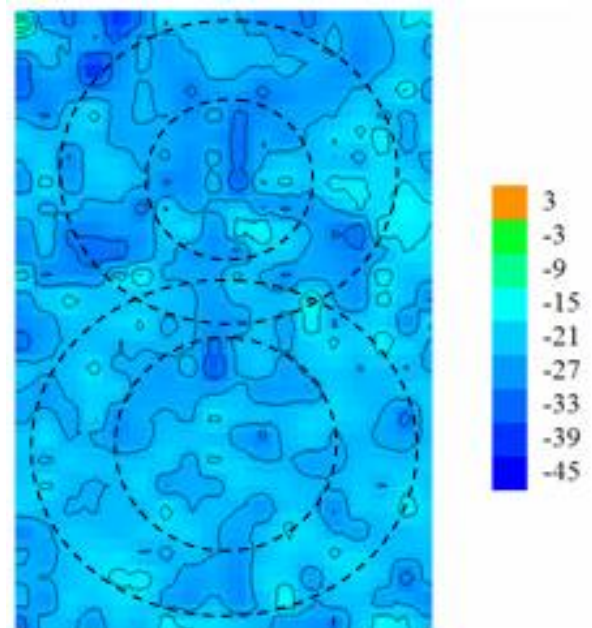

(f) Mapa 5: $\mathrm{t}_{\text {inicial }}=24 \mathrm{~h} ; \mathrm{t}_{\text {final }}=24 \mathrm{~h} 06 \mathrm{~min}$

Figura 26. Microscopia óptica da região da amostra $1(f=80 \mathrm{kHz})$ selecionada para análise e mapas gerados por SVET em função do tempo de imersão em PBS no PCA. 


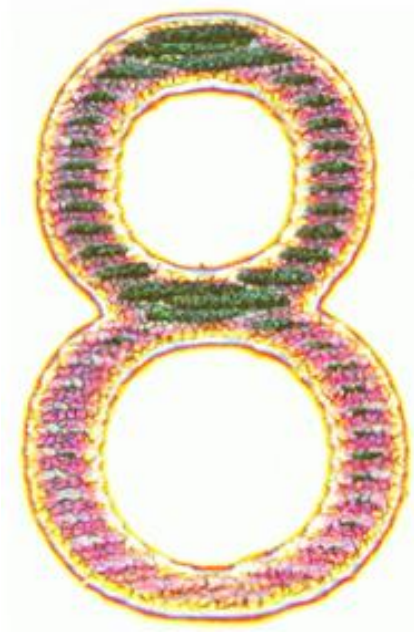

(a) Microscopia óptica antes do ensaio.

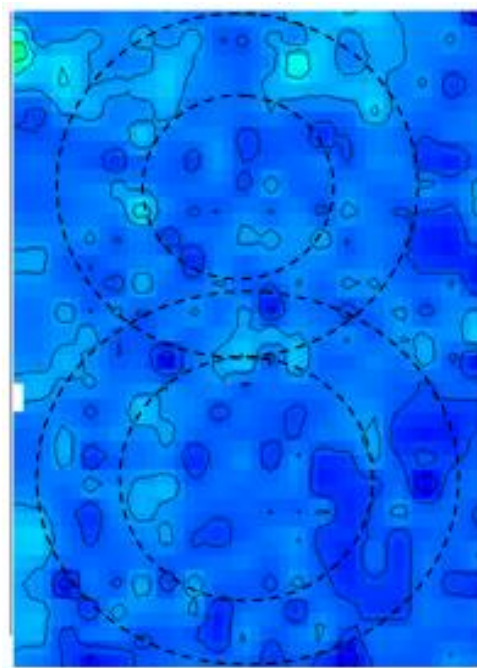

(c) Mapa 2: $t_{\text {inicial }}=1 \mathrm{~h} 30 \mathrm{~min} ; \mathrm{t}_{\text {final }}=1 \mathrm{~h} 36 \mathrm{~min}$.
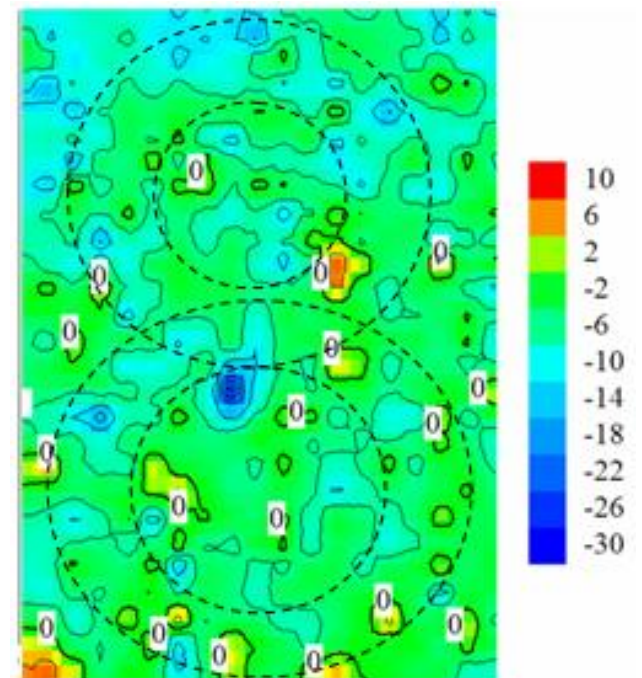

(e) Mapa 4: $\mathrm{t}_{\text {inicial }}=17 \mathrm{~h} ; \mathrm{t}_{\text {final }}=17 \mathrm{~h} 06 \mathrm{~min}$.

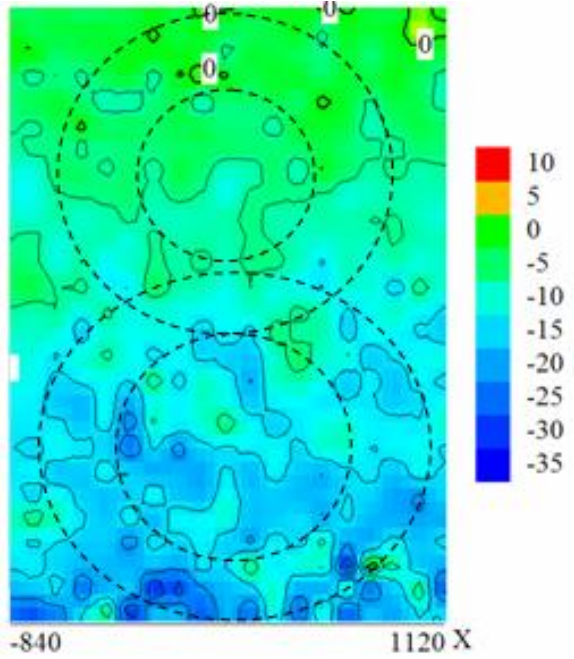

(b) Mapa 1: $\mathrm{t}_{\text {inicial }}=0 \mathrm{~min} ; \mathrm{t}_{\text {final }}=6 \mathrm{~min}$.

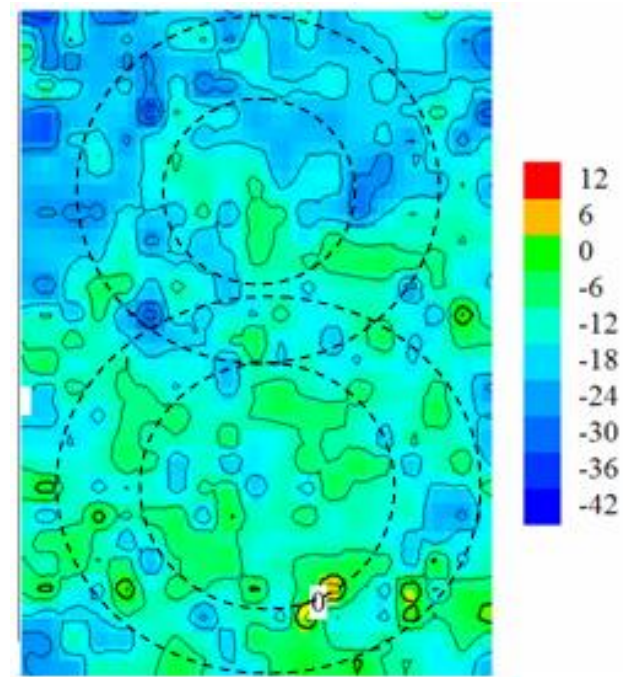

(d) Mapa 3: $\mathrm{t}_{\text {inicial }}=2 \mathrm{~h} ; \mathrm{t}_{\text {final }}=2 \mathrm{~h} 06 \mathrm{~min}$

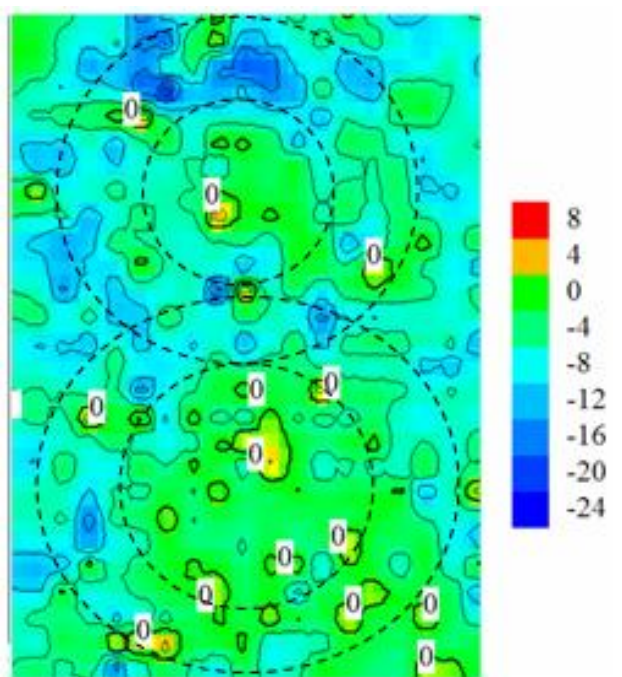

(f) Mapa 5: $t_{\text {inicial }}=24 \mathrm{~h} ; \mathrm{t}_{\text {final }}=24 \mathrm{~h} 06 \mathrm{~min}$

Figura 27. Microscopia óptica da região da amostra $2(f=188 \mathrm{kHz})$ selecionada para análise e mapas gerados por SVET em função do tempo de imersão em PBS no PCA. 
Diferentemente, para os parâmetros de marcação por feixe laser utilizados na amostra 2, (Figura 27), para períodos de imersão de até 1h30min, mapas 1 e 2 das imagens (b) e (c), não foram encontradas grandes regiões com densidades de correntes anódicas, sendo que para o mapa 2, Figura 27 (c) se tem a condição de maior densidade de correntes catódicas.

Repetindo-se as medidas na mesma área selecionada apresentada na Figura 27, após tempos de imersão mais longos, encontram-se regiões menos catódicas e mais anódicas, como estão apresentados nos mapas 3, 4 e 5 das imagens (d), (e) e (f).

Nas Figuras 28 e 29 estão apresentadas as regiões selecionadas para análise e os mapas gerados no potencial de circuito aberto (PCA) para os mesmos períodos de imersão em PBS, para as amostras 3 e 4.

$\mathrm{Na}$ Figura 28, correspondente à amostra 3, marcada com $\mathrm{f}=296 \mathrm{kHz}$, notou-se a presença de áreas anódicas e catódicas nos primeiros tempos de imersão no PCA, apresentadas na imagem: (b) e, após períodos 1h30min e $2 \mathrm{~h}$ de imersão, imagens (c) e (d), as densidades de correntes diminuíram de modo que foram obtidos mapas com densidades de correntes catódicas, o que sugere um crescimento do filme passivo nestas condições. Entretanto, o filme formado não foi homogêneo durante todo o período de análise. Para tempos de imersão superiores a $17 \mathrm{~h}$, a densidade de correntes catódicas diminuiu, favorecendo o surgimento de pequenos sítios anódicos localizados próximo às marcações por feixe laser com os parâmetros da amostra 3.

Analogamente ao observado em pesquisas anteriores envolvendo o mesmo biomaterial marcado por feixe laser com parâmetros industriais [1, 3], onde após longos tempos de imersão no potencial de circuito aberto (PCA), o crescimento do filme passivo dificultou a visualização da distribuição de áreas anódicas e catódicas nas amostras. Condições mais agressivas são indicadas para se observar estas regiões claramente distribuídas, neste caso. 


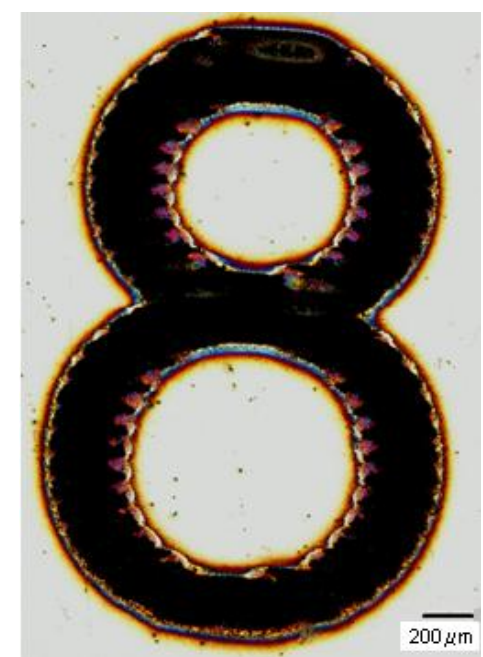

a) Microscopia óptica antes do ensaio.

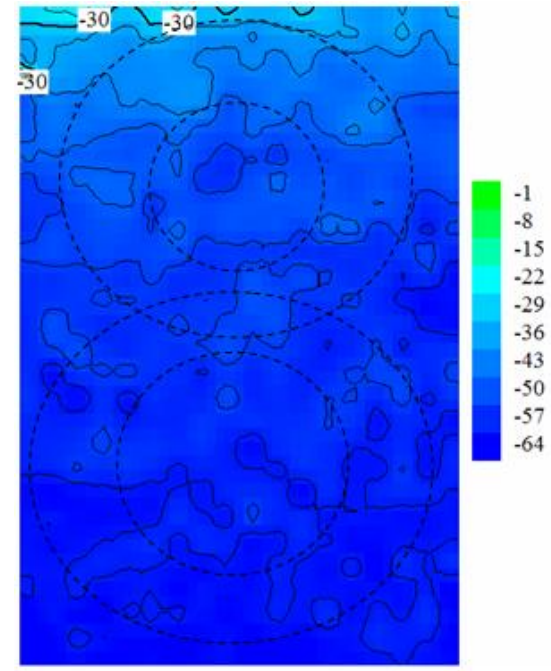

(c) Mapa 2: $\mathrm{t}_{\text {inicial }}=1 \mathrm{~h} 30 \mathrm{~min} ; \mathrm{t}_{\text {final }}=1 \mathrm{~h} 36 \mathrm{~min}$.

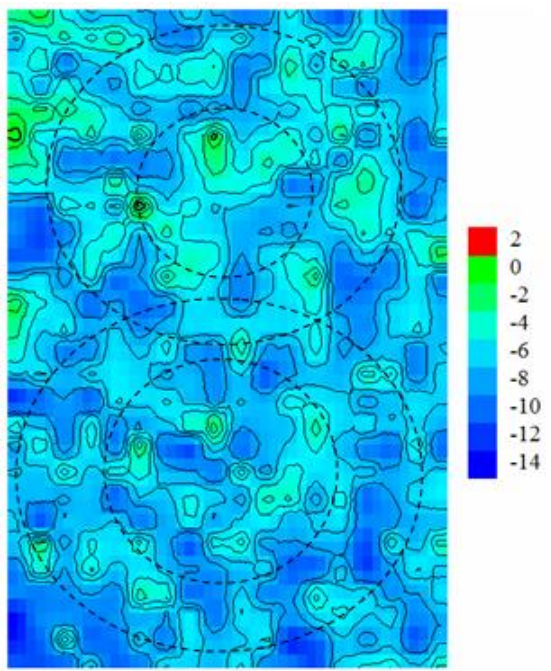

(e) Mapa 4: $t_{\text {inicial }}=17 \mathrm{~h} ; \mathrm{t}_{\text {final }}=17 \mathrm{~h} 06 \mathrm{~min}$.

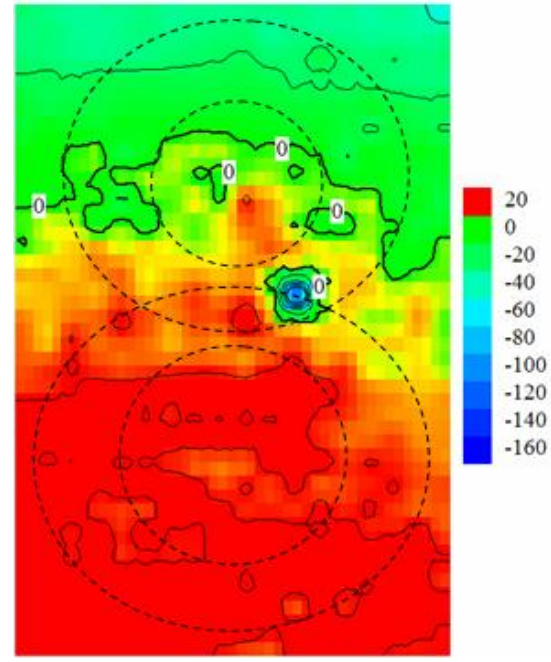

(b) Mapa 1: $\mathrm{t}_{\text {inicial }}=0 \mathrm{~min} ; \mathrm{t}_{\text {final }}=6 \mathrm{~min}$.

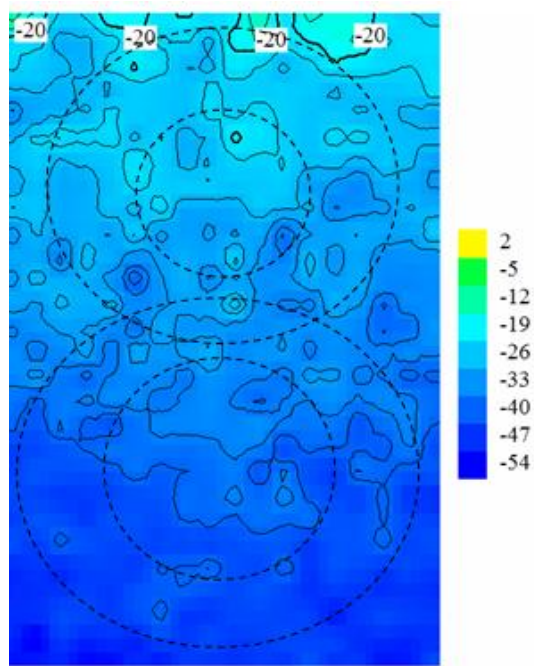

(d) Mapa 3: $\mathrm{t}_{\text {inicial }}=2 \mathrm{~h} ; \mathrm{t}_{\text {final }}=2 \mathrm{~h} 06 \mathrm{~min}$.

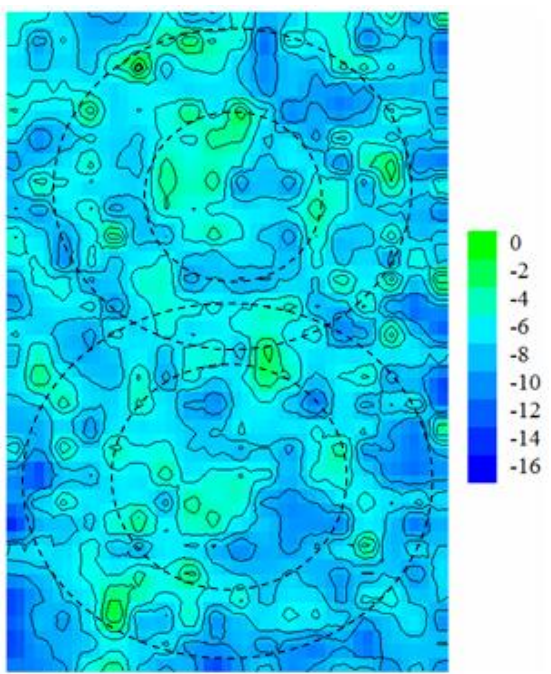

(f) Mapa 5: $\mathrm{t}_{\text {inicial }}=24 \mathrm{~h} ; \mathrm{t}_{\text {final }}=24 \mathrm{~h} 06 \mathrm{~min}$.

Figura 28. Microscopia óptica da região da amostra $3(f=296 \mathrm{kHz})$ selecionada para análise e mapas gerados por SVET em função do tempo de imersão em PBS no PCA. 


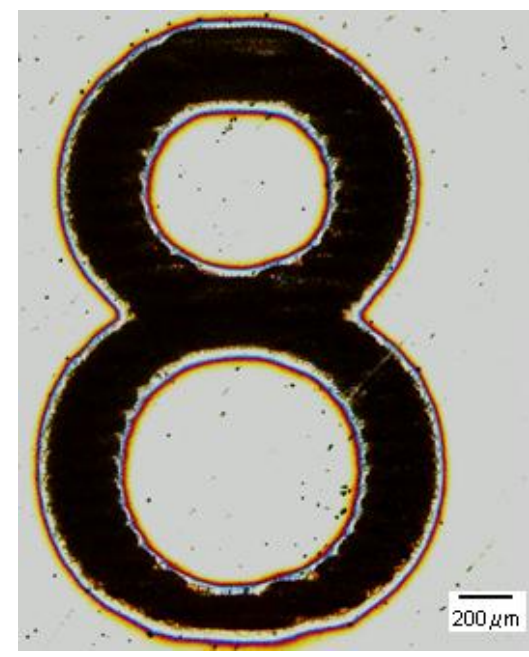

a) Microscopia óptica antes do ensaio.

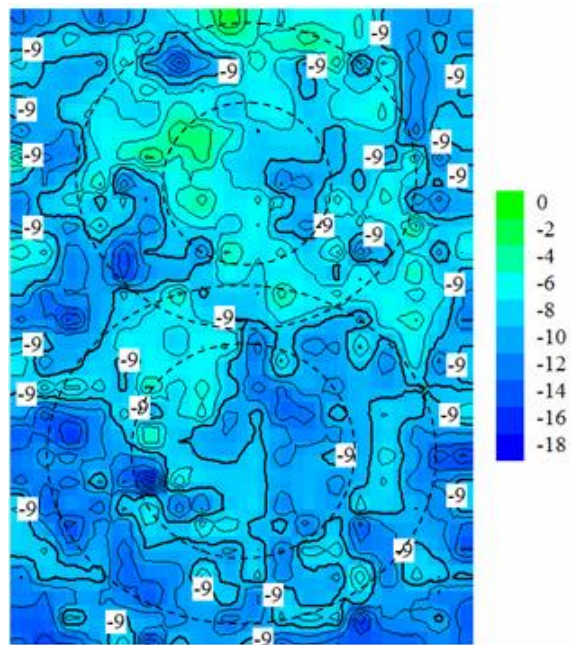

(c) Mapa 2: $\mathrm{t}_{\text {inicial }}=1 \mathrm{~h} 30 \mathrm{~min} ; \mathrm{t}_{\text {final }}=1 \mathrm{~h} 36 \mathrm{~min}$.

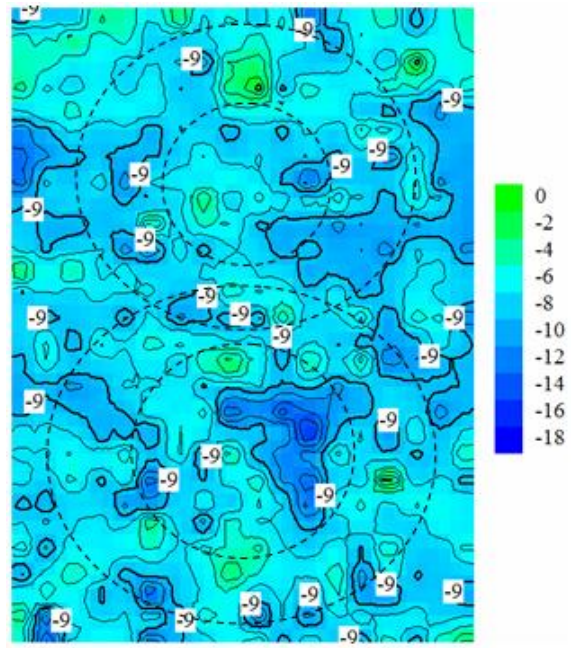

(e) Mapa 4: $t_{\text {inicial }}=17 \mathrm{~h} ; \mathrm{t}_{\text {final }}=17 \mathrm{~h} 06 \mathrm{~min}$.

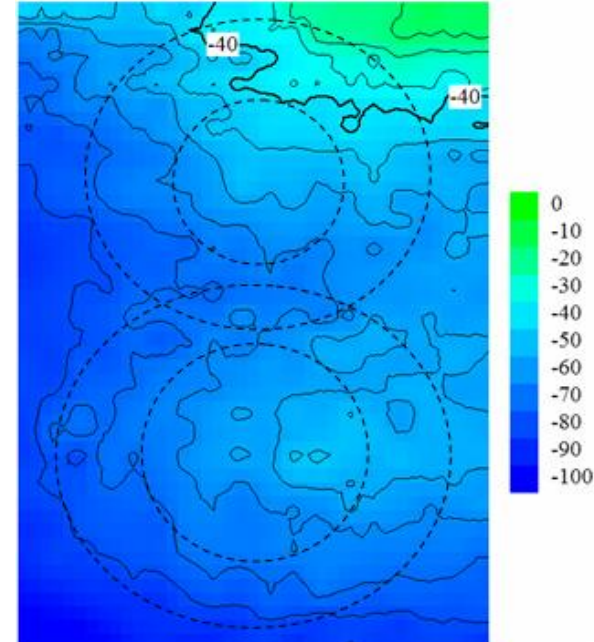

(b) Mapa 1: $\mathrm{t}_{\text {inicial }}=0 \mathrm{~min} ; \mathrm{t}_{\text {final }}=6 \mathrm{~min}$.

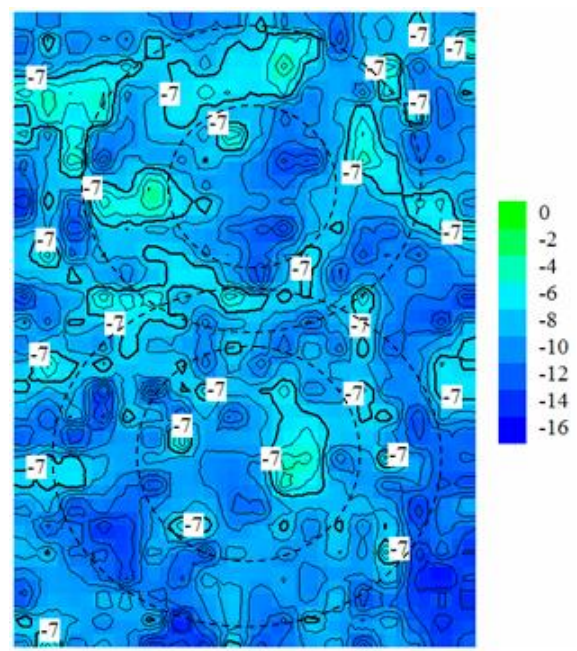

(d) Mapa 3: $\mathrm{t}_{\text {inicial }}=2 \mathrm{~h} ; \mathrm{t}_{\text {final }}=2 \mathrm{~h} 06 \mathrm{~min}$.

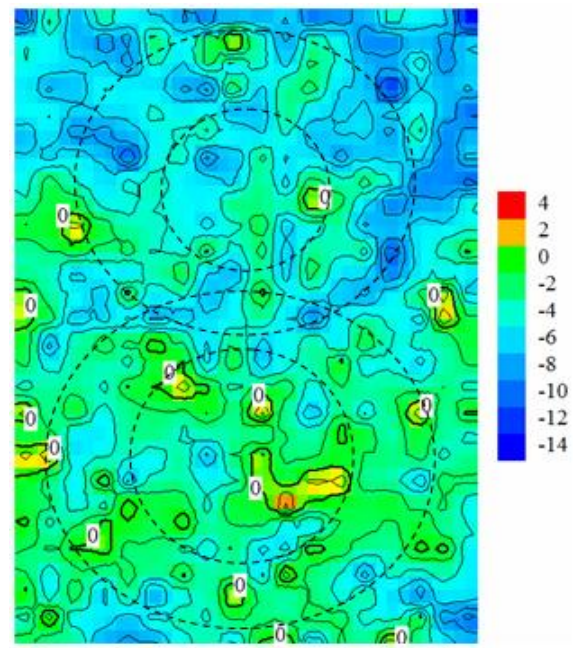

(f) Mapa 5: $t_{\text {inicial }}=24 \mathrm{~h} ; \mathrm{t}_{\text {final }}=24 \mathrm{~h} 06 \mathrm{~min}$.

Figura 29. Microscopia óptica da região da amostra $4(f=350 \mathrm{kHz})$ selecionada para análise e mapas gerados por SVET em função do tempo de imersão em PBS no PCA. 
$\mathrm{Na}$ Figura 29, correspondente à amostra 4, observou-se a presença somente de áreas catódicas nos primeiros tempos de imersão no PCA. Após períodos de 1h30min, $2 \mathrm{~h}$ e $17 \mathrm{~h}$ a densidade de correntes catódicas diminuiu expressivamente; contudo, não se pôde visualizar a formação de regiões anódicas. A partir de períodos de imersão da ordem de 24 horas, a densidade de corrente catódicas continuou a diminuir e surgiram locais com densidades de correntes anódicas nas regiões marcadas a laser e nas suas proximidades. Este efeito sugere a deterioração do filme passivo para longos períodos de imersão nas condições de marcação utilizadas na amostra 4.

\subsection{Potencial de circuito aberto}

As curvas de variação de potencial de corrosão em circuito aberto (PCA), em função do tempo de imersão em solução de fosfato tamponada (PBS), naturalmente aerada a $37^{\circ} \mathrm{C}$ estão apresentadas nas Figuras 30 e 31 . Os ensaios foram realizados para dez amostras do aço inoxidável austenítico ABNT NBR ISO 5832-1, para cada uma das nove condições: sem marcações e com marcações e texturizações por laser, alterando-se as frequências de pulso em 4 níveis. As amostras permaneceram imersas em solução por um período de 12 horas ou 43200 segundos, após o qual foram realizados os ensaios de espectroscopia de impedância eletroquímica (EIE). A análise da Figura 30 permite a compreensão de alguns fenômenos que se repetiram para várias amostras dependendo do tipo de superfície avaliado.

A curva apresentada na cor preta, referente ao aço sem marcações, é representativa do montante de dez ensaios realizados e apresenta potencial de circuito aberto mais constante pelo período avaliado, o que sugere a existência de um filme passivo mais estável sobre o aço. A partir dos primeiros $4000 \mathrm{~s}$ de imersão há um aumento no potencial, que com o passar do tempo exibe comportamento mais uniforme até atingir um valor da ordem de $0,18 \mathrm{~V}$ (SCE) em 12 horas de ensaio. 


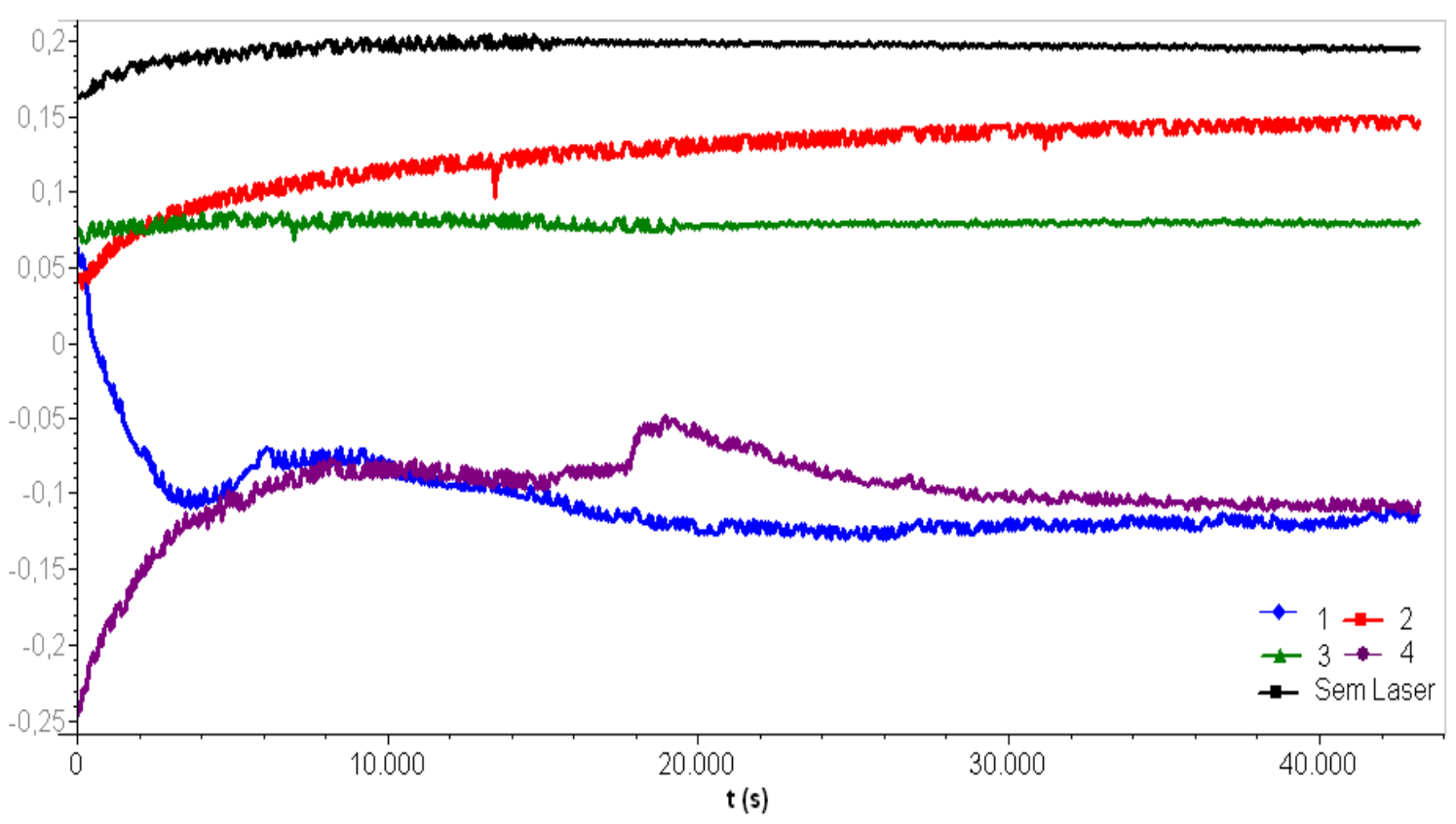

Figura 30. Potencial de corrosão em circuito aberto variando ao longo do tempo em solução PBS, naturalmente aerada a $37^{\circ} \mathrm{C}$ nas condições: padrão e com marcações a laser.

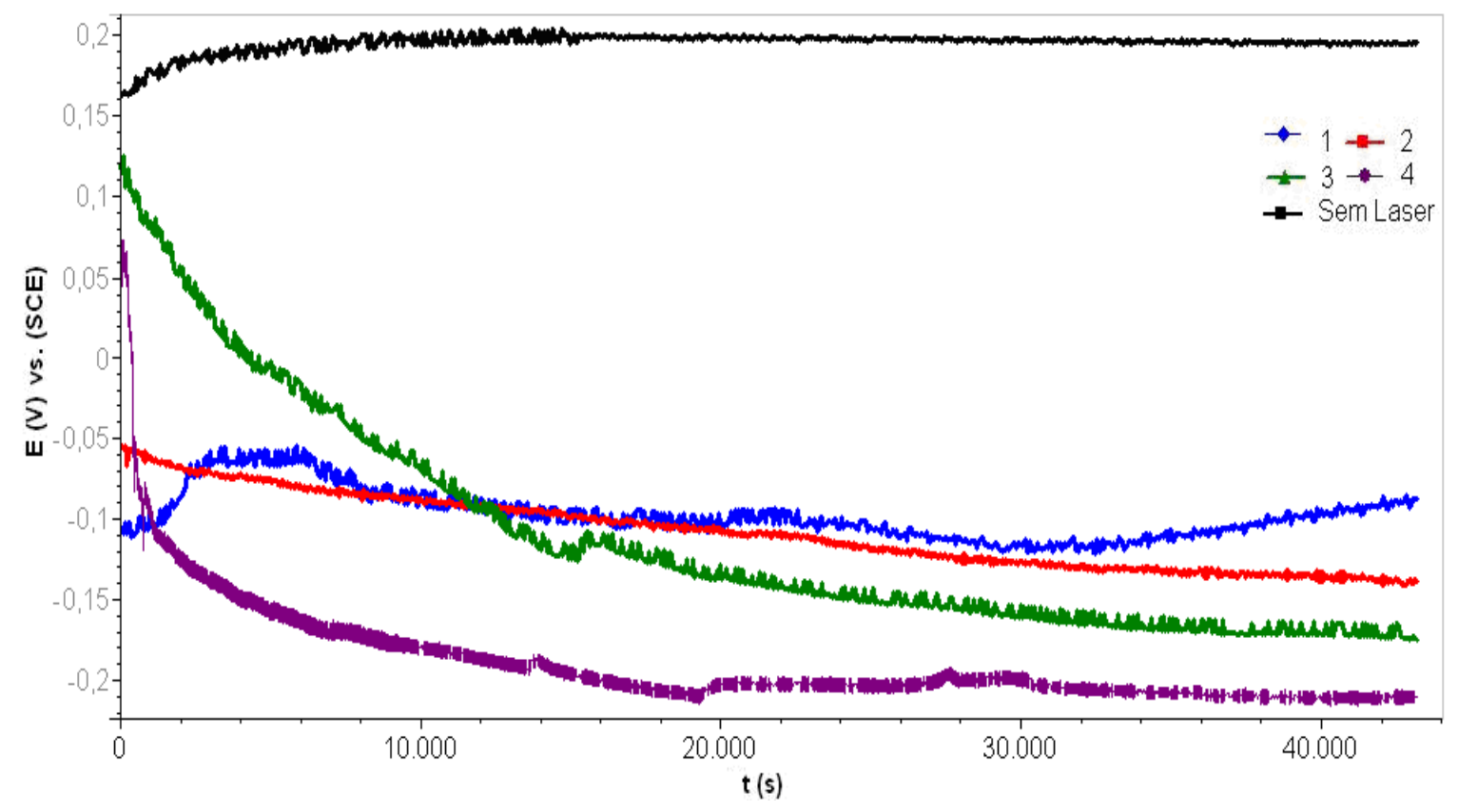

Figura 31. Potencial de corrosão em circuito aberto variando ao longo do tempo em solução PBS, naturalmente aerada a $37^{\circ} \mathrm{C}$ nas condições: padrão e com texturizações a laser.

A maioria das amostras marcadas por feixe laser com os parâmetros 2 e 4 apresentaram tendência de aumento de potencial para valores mais nobres e mais estáveis. A amostra 1 com marcações apresentou queda no potencial em 
circuito aberto para os primeiros tempos de imersão, em torno de $4000 \mathrm{~s}$. Esta queda de potencial pode ser associada com o ataque de regiões mais ativas da superfície, devido à formação de micropilhas relacionadas com defeitos gerados pela marcação a laser. $O$ ataque das regiões mais ativas pode ser considerado como uma "limpeza" parcial da superfície por ataque corrosivo que é seguida por uma superfície mais homogênea responsável pela recuperação de potencial nos momentos finais da imersão. A amostra 3, curva verde, apresentou valores de potenciais mais uniformes ao longo do período de imersão em circuito aberto.

Para períodos de imersão mais longos nesta solução, em torno de $25000 \mathrm{~s}$, todas as amostras com marcações e padrão, apresentadas na Figura 30, mostram comportamento uniforme do potencial de corrosão, indicando a formação de um filme passivo estável.

Com relação às amostras texturizadas a laser, mostradas na Figura 31, verifica-se uma queda do potencial de corrosão ao longo do tempo de imersão. As curvas apresentadas acima são exemplos da reprodutibilidade do comportamento apresentado, onde para a amostra nomeada na legenda como amostra 1, curva de cor azul, ocorreu um pequeno aumento de potencial para os primeiros tempos de imersão, 3500 s, logo após houve uma queda suave e constante; indicando também estabilidade do filme passivo formado sobre as mesmas.

Para as amostras 2, 3 e 4, da Figura 31, o feixe laser, nas condições utilizadas, causou um contínuo decréscimo do potencial de corrosão em circuito aberto. A mesma figura mostra uma tendência de recuperação de potencial para valores mais nobres, para a amostra 1, ocorrida após período de baixa oscilação de potencial, provavelmente devido a um filme superficial menos defeituoso em comparação às demais condições de acabamento superficial de amostras. 0 efeito do feixe laser depende da área onde o potencial foi medido.

De maneira geral, as texturizações por feixe laser afetaram a camada passiva formada sobre este aço inoxidável austenítico e conduziram o potencial de corrosão a valores menos nobres quando comparados aos obtidos nas amostras sem tratamentos e com marcações, independentemente da frequência. 


\subsection{Polarização Potenciodinâmica Cíclica}

Nas figuras seguintes estão mostradas as curvas de polarização potenciodinâmica cíclica resultantes dos ensaios conduzidos em solução PBS naturalmente aerada a $37^{\circ} \mathrm{C}$, que corresponde à temperatura corpórea, com eletrodo de referência de Calomelano Saturado (SCE) e contra-eletrodo de platina platinizada. A velocidade de varredura, na direção anódica, foi de 0,167 mV.s.1 de acordo com a norma ABNT NBR 15613-2:2010 [74], a partir do potencial de corrosão em circuito aberto.

Os resultados para as amostras marcadas por feixe laser e sem marcações estão exibidos na Figura 32. Este resultado representa o efeito do laser na susceptibilidade à corrosão deste aço inoxidável; as curvas apresentaram valores de quebra do filme passivo desde cerca de $+0,3 \vee(E C S)$ até $+0,8 \vee(E C S)$.

Esta variabilidade é esperada para superfícies heterogêneas como é o caso das amostras com marcações via feixe laser, onde as condições das amostras nas condições 1 e 4 apresentaram maior resistência à corrosão localizada. Nota-se que os potenciais de quebra do filme para todas as condições de amostras marcadas a laser estão abaixo das amostras sem marcação, isto é, com acabamento polido até $1 \mu \mathrm{m}$.

Na Figura 33 são apresentadas as curvas de polarização cíclica obtidas no sentido anódico para o aço inoxidável austenítico este biomaterial em PBS a $37^{\circ} \mathrm{C}$ para amostras texturizadas a laser e padrão. Nota-se que a quebra do filme se dá em potenciais entre $+0,3 \vee(E C S)$ e +0,6 V (ECS). Para a amostra 1 texturizada, este valor não está bem evidenciado pelo gráfico. De forma semelhante às amostras marcadas a laser com os mesmos parâmetros, nota-se que os potenciais de quebra do filme para todas as condições de amostras texturizadas a laser estão abaixo das amostras sem marcação, devido ao aumento de área efetiva e geração de heterogeneidades pelo tratamento de texturização nas condições mencionadas. 


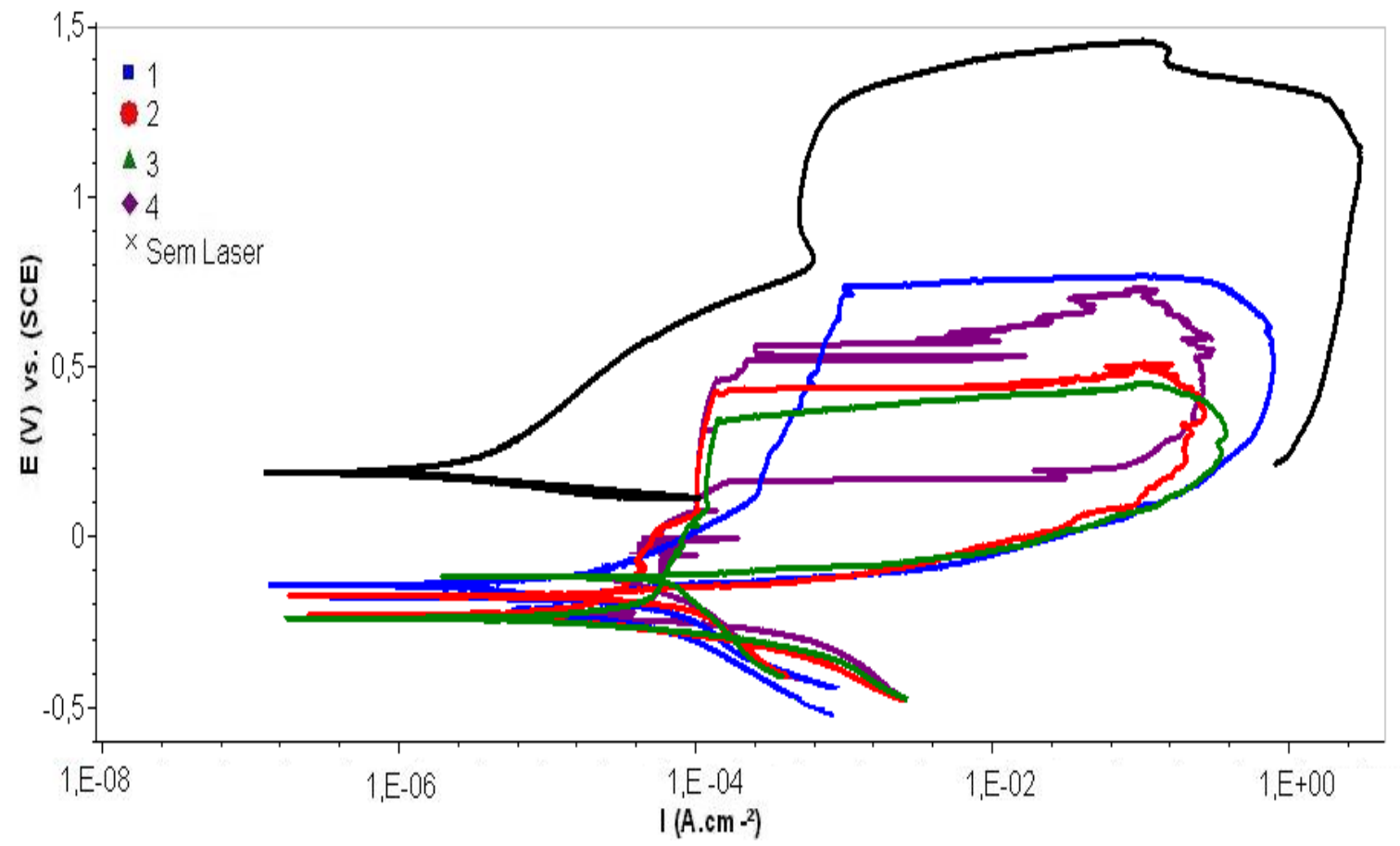

Figura 32. Curvas de polarização cíclica obtidas no sentido anódico para o aço inoxidável austenítico ABNT NBR ISO $5832-1$ em PBS a $37^{\circ} \mathrm{C}$ para amostras marcadas a laser e padrão.

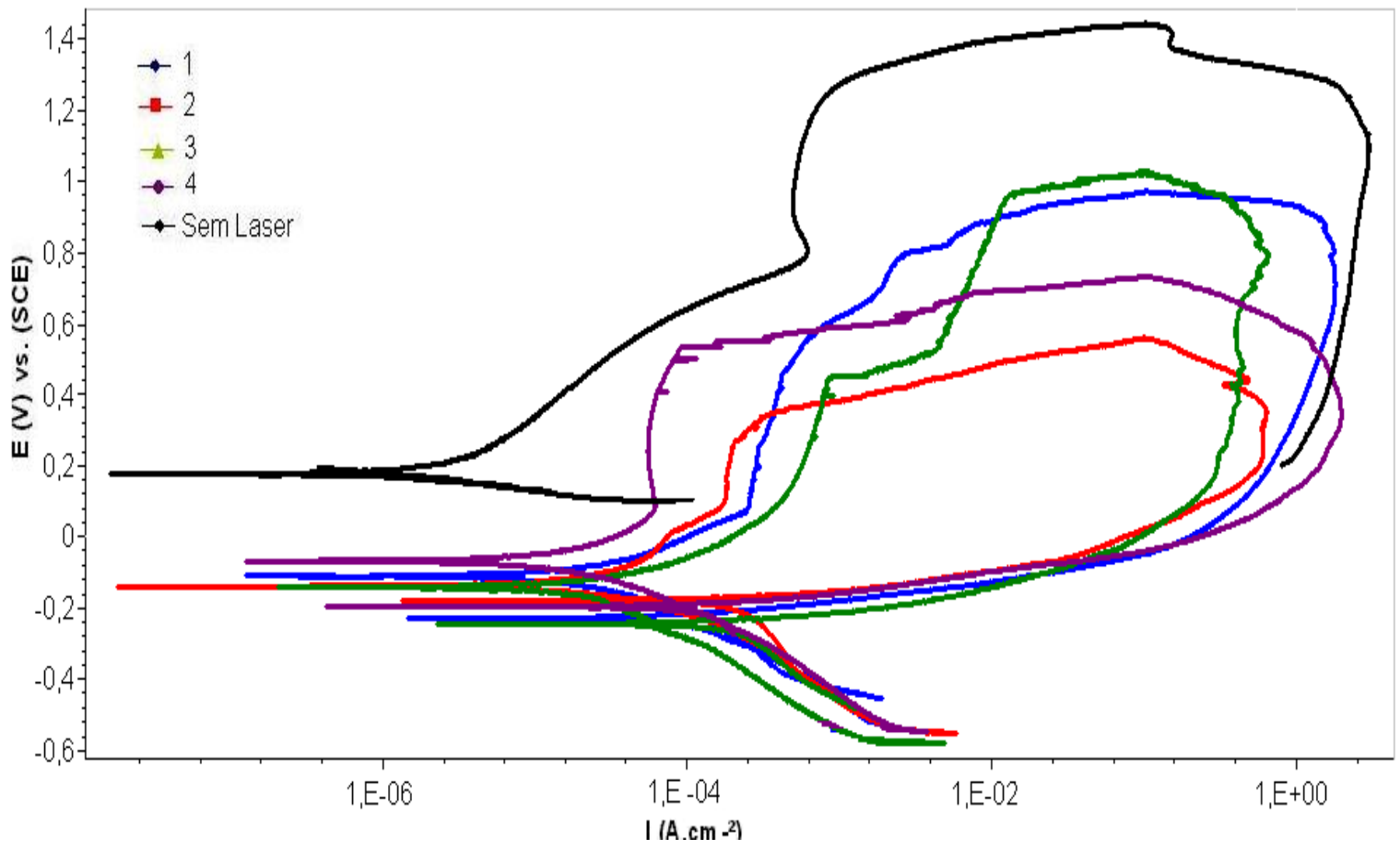

Figura 33. Curvas de polarização cíclica obtidas no sentido anódico para o aço inoxidável austenítico ABNT NBR ISO 5832-1 em PBS a $37^{\circ} \mathrm{C}$ para amostras texturizadas a laser e padrão.

Nas Figuras 34 a 37 estão mostradas as curvas de polarização cíclica para este biomaterial nas condições: padrão, marcadas e texturizadas, apresentadas em conjunto, para efeito de comparação entre as amostras 1 a 4. 


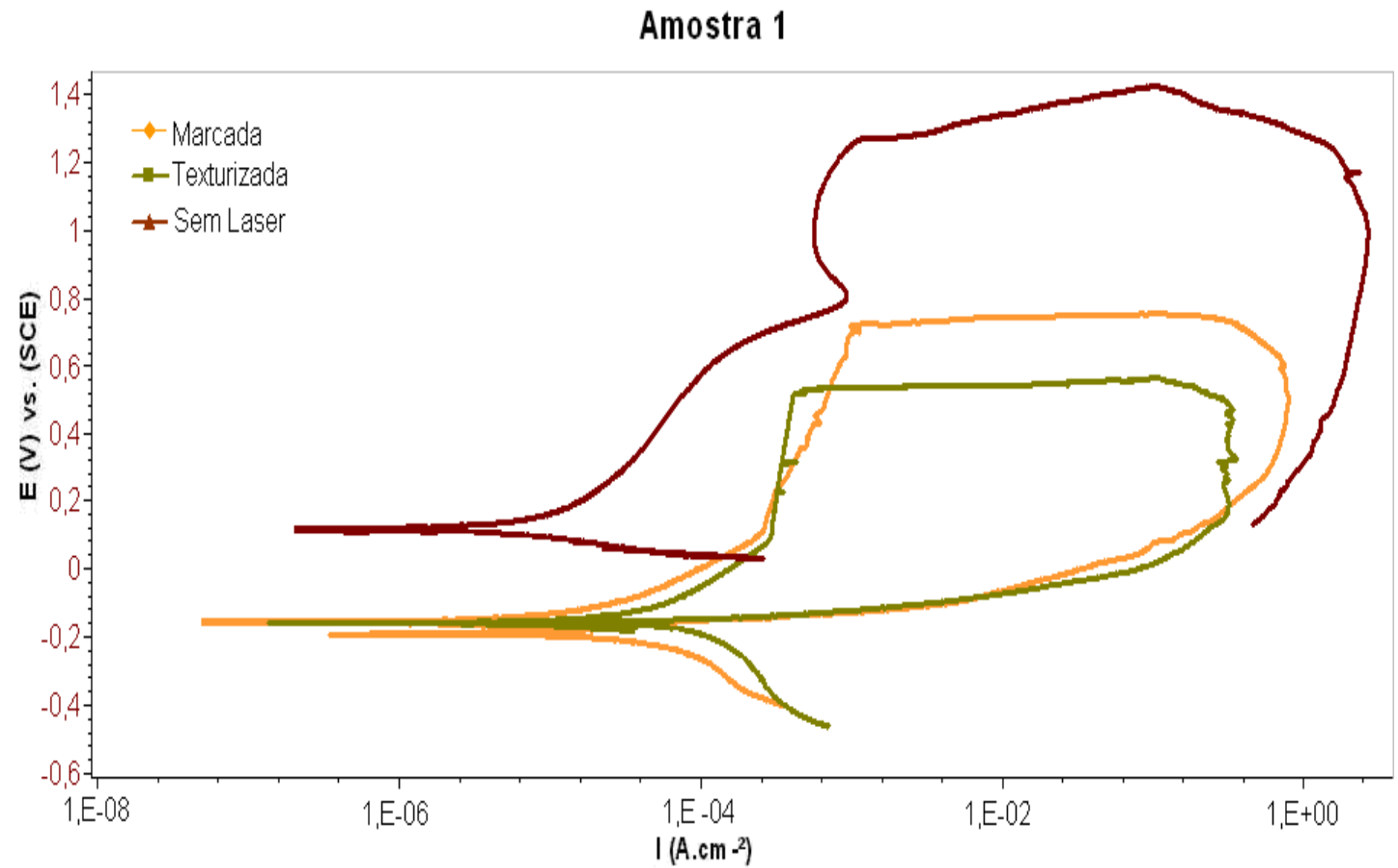

Figura 34. Curvas de polarização cíclica obtidas no sentido anódico para o aço inoxidável austenítico ABNT NBR ISO $5832-1$ em PBS a $37^{\circ} \mathrm{C}$ para a amostra $1(\mathrm{f}=80 \mathrm{kHz})$ nas três condições de acabamento superficial.

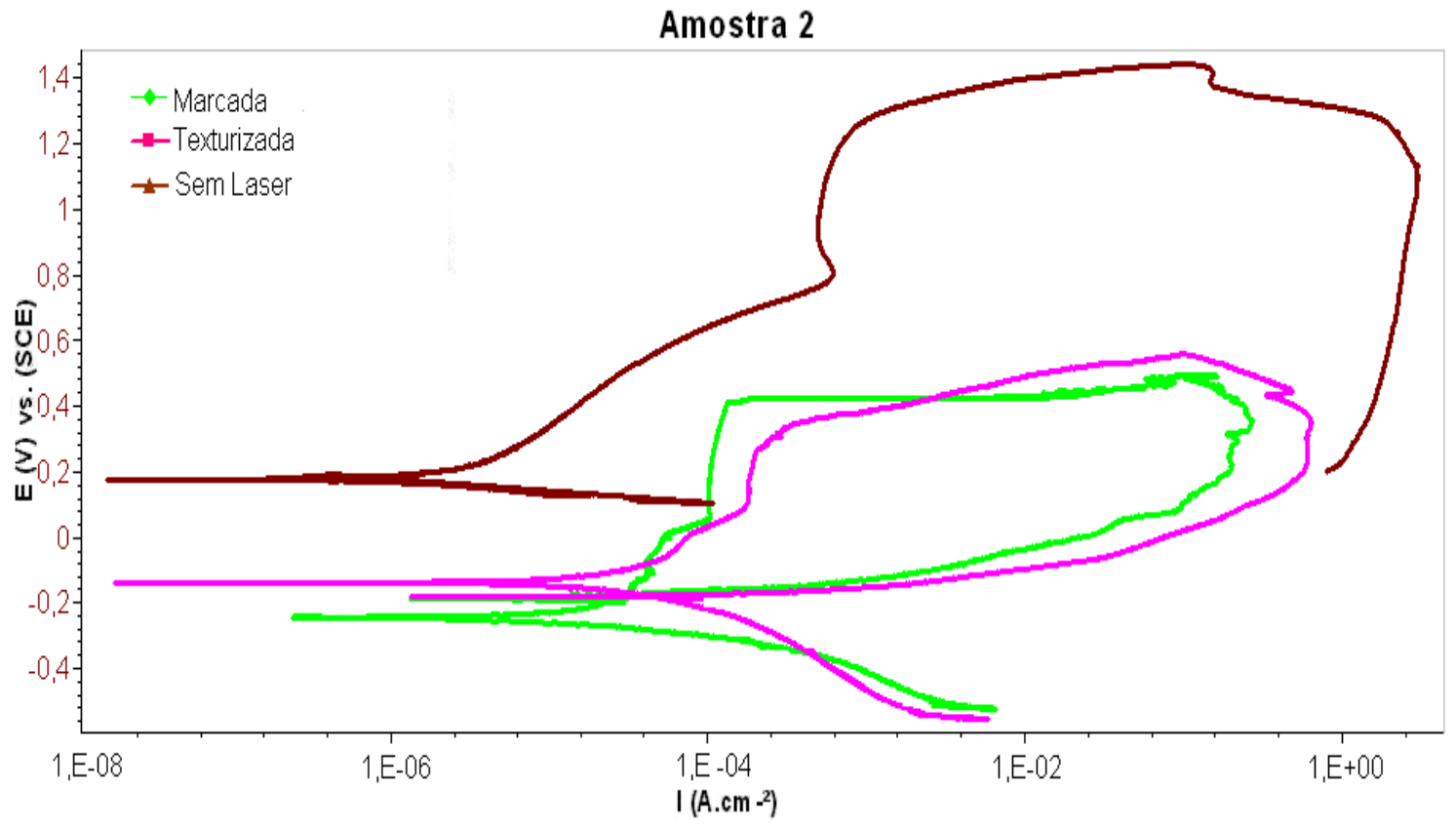

Figura 35. Curvas de polarização cíclica obtidas no sentido anódico para o aço inoxidável austenítico ABNT NBR ISO 5832-1 em PBS a $37^{\circ} \mathrm{C}$ para a amostra $2(\mathrm{f}=188 \mathrm{kHz})$ nas três condições de acabamento superficial. 


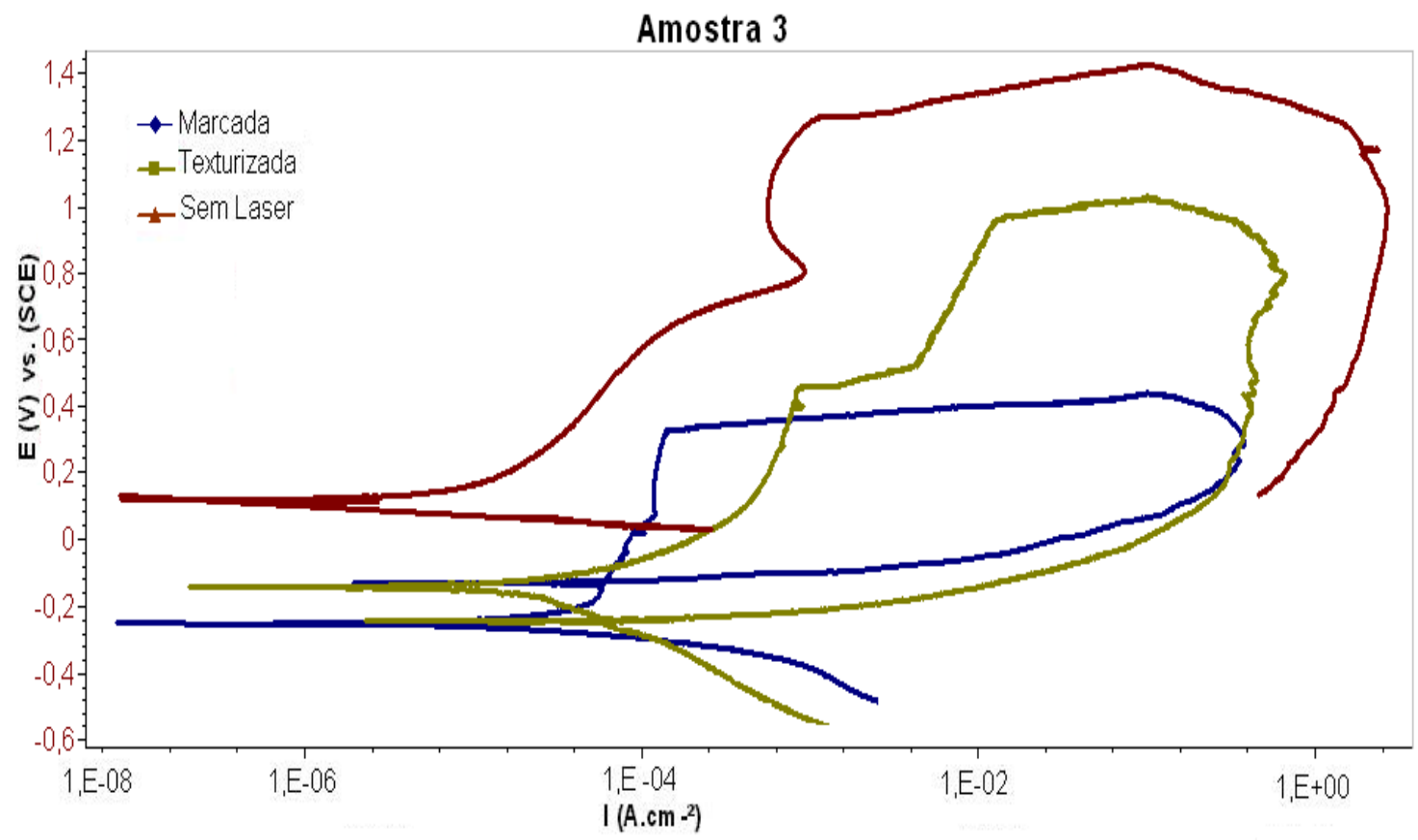

Figura 36. Curvas de polarização cíclica obtidas no sentido anódico para o aço inoxidável austenítico ABNT NBR ISO 5832-1 em PBS a $37^{\circ} \mathrm{C}$ para a amostra $3(f=296 \mathrm{kHz}$ ) nas três condições de acabamento superficial.

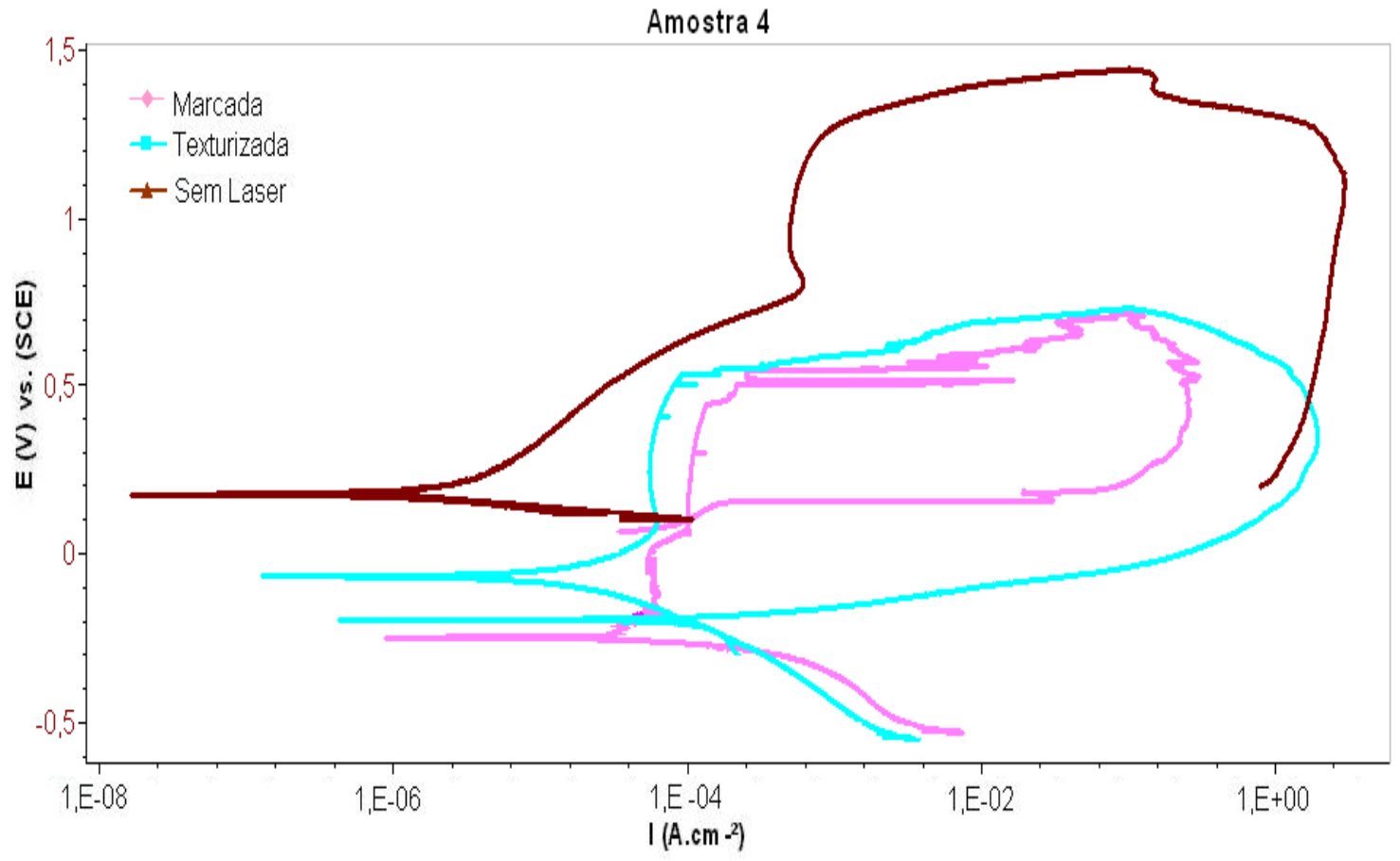

Figura 37. Curvas de polarização cíclica obtidas no sentido anódico para o aço inoxidável austenítico ABNT NBR ISO 5832-1 em PBS a $37^{\circ} \mathrm{C}$ para a amostra 4 ( $f=350 \mathrm{kHz}$ ) nas três condições de acabamento superficial. 
Nas Figuras 34 a 37 encontra-se uma comparação das polarizações realizadas nas amostras tratadas com as técnicas de marcação e texturização por feixe laser com as amostras sem tratamento.

Em cada uma dessas figuras não há variação de nenhum parâmetro do feixe laser, a única diferença consiste em que as amostras marcadas possuem a gravação do algarismo oito em regiões que cobrem uma pequena parcela da superfície; enquanto que as amostras texturizadas têm as superfícies totalmente preenchidas pelas linhas justapostas que compuseram as texturizações, como apresentadas anteriormente.

A análise destas figuras evidencia que, nas condições utilizadas, o laser causou um efeito deletério nas amostras do referido aço utilizado para biomateriais, uma vez que diminui a sua resistência à corrosão, quando comparado às amostras sem tratamento.

Os potenciais de pite para as amostras nas condições 1 e 2 com texturização a laser são inferiores aos observados para as amostras marcadas com os mesmos parâmetros e para as não marcadas, o que evidencia a maior susceptibilidade da região texturizada a laser à corrosão por pite. A amostra 3 com marcações apresentou potenciais de pite inferiores aos obtidos na amostra 3 texturizada. A comparação das curvas de polarização para as superfícies da amostra 4 mostra que antes da quebra do filme passivo nas amostras com marcação e texturização a laser notam-se oscilações de corrente, que indicam a nucleação de pites.

Para os tratamentos de marcação a laser, os potenciais de pite obtidos foram em torno de $+0,7 \mathrm{~V},+0,4 \mathrm{~V},+0,3 \mathrm{~V}$ e $+0,5 \mathrm{~V}$, para as amostras nas condições 1, 2, 3 e 4, respectivamente. Entretanto, para os tratamentos de texturização por feixe laser, os potenciais encontrados foram em torno de $+0,5 \mathrm{~V}$, $+0,3 \mathrm{~V},+0,45 \mathrm{~V}$ e $+0,5 \mathrm{~V}$, respectivamente para as amostras 1, 2, 3 e 4

A grande histerese observada nas curvas para as condições avaliadas indica que há formação de pites nos três casos e que a tendência à repassivação dos pites é muito baixa no meio de ensaio adotado.

O ensaio de polarização cíclica foi realizado à taxa de varredura de $0,167 \mathrm{mV} . \mathrm{s}^{-1}$. Esta velocidade, que é relativamente lenta, está de acordo com a norma ABNT NBR 15613-2:2010 [74], e foi utilizada em todos os ensaios a fim de 
que proporcionasse tempo de estabilização das reações na interface do filme passivo com o meio de ensaio.

A análise das figuras anteriores sugere que o óxido formado sobre a superfície das amostras submetidas ao processo de tratamento por laser apresenta maior quantidade de defeitos do que o encontrado nas outras condições estudadas. Estes defeitos são resultantes do efeito térmico causado pelo laser, que funde o material gerando a gravação desejada e, são relacionados às mudanças de caráter topográfico das superfícies tratadas como, por exemplo, depressões, picos, vales, crateras e aumento de rugosidade. O fenômeno da corrosão sempre ocorre em heterogeneidades.

Com base nas curvas de polarização potenciodinâmicas anódicas foram obtidos os valores de potencial de corrosão $\left(E_{c o r r}\right)$ e potencial de pite $\left(E_{\text {pite }}\right)$, correntes de corrosão, $\beta$ a e $\beta c$ para as amostras marcadas e texturizadas por feixe laser, bem como sem tratamento, como estão apresentados na Tabela 11.

Tabela 11. Valores de potenciais de corrosão e de pite, correntes de corrosão, $\beta a$ e $\beta c$ para amostras com marcações e texturizações a laser, e padrão. (Média calculada para dez resultados em cada condição de superfície).

\begin{tabular}{c|c|c|c|c|c}
\hline Amostras & $E_{\text {corr }}(\mathrm{V})$ & $E_{\text {pite }}(\mathrm{V})$ & $i_{\text {corr }}(\mu \mathrm{A})$ & $\begin{array}{c}\beta a \\
(\mathrm{mV} / \text { década })\end{array}$ & $\begin{array}{c}\beta c \\
(\mathrm{mV} / \text { década })\end{array}$ \\
\hline Marcada-1 & $-215,15$ & $+0,73$ & 0,009 & 214,4 & $-101,8$ \\
\hline Marcada-2 & $-196,84$ & $+0,42$ & 0,028 & 637,8 & $-141,9$ \\
\hline Marcada-3 & $-207,12$ & $+0,36$ & 0,049 & 823,3 & $-149,3$ \\
\hline Marcada-4 & $-104,05$ & $+0,50$ & 0,121 & 43,9 & $-169,7$ \\
\hline Texturizada-1 & $-103,09$ & $+0,52$ & 0,030 & 195,7 & $-213,2$ \\
\hline Texturizada-2 & $-108,87$ & $+0,32$ & 0,034 & 299,0 & $-209,5$ \\
\hline Texturizada-3 & $-142,02$ & $+0,45$ & 0,064 & 297,0 & $-251,1$ \\
\hline Texturizada-4 & $-98,12$ & $+0,53$ & 0,026 & 525,4 & $-171,1$ \\
\hline Padrão & 99,97 & $+1,34$ & 0,008 & 345,6 & $-64,3$ \\
\hline
\end{tabular}

Os potenciais de pite obtidos para as amostras padrão de referência foram da ordem de $1,2 \mathrm{~V}$, próximos ao potencial da reação de evolução do oxigênio (r.e.o). 
Neste caso, a observação da superfície via MEV e por microscopia confocal, após ensaio de polarização, evidenciou a presença de pequena quantidade de pites de corrosão, ou até a sua ausência.

\subsection{Análises das Superfícies das Amostras Polarizadas}

As amostras que receberam tratamento de texturização e marcação a laser, com os parâmetros citados anteriormente, foram avaliadas após o ensaio de polarização cíclica. Para fins de comparação amostras sem tratamento, identificadas como padrão de referência, também foram analisadas. Nota-se claramente uma associação de sítios de corrosão com elevada concentração de pites nas amostras tratadas a laser, independentemente do tipo de tratamento e/ou parâmetro utilizado. A superfície marcada pelo laser apresenta rugosidade típica de estruturas brutas de fusão, como pode ser observado nas imagens das Figuras 38 (a) e (b) obtidas por microscopia eletrônica de varredura (MEV).

Nas Figuras 38 (a) e (b) são mostrados que os locais com marcações a laser são os mais propensos ao início do fenômeno da corrosão, seja por pite ou em frestas; o que pôde ser verificado após a análise de cada amostra polarizada.

Utilizando-se a mesma técnica de microscopia eletrônica de varredura (MEV) foi possível observar amostras que de forma não intencional, mas devido ao arranjo experimental, apresentaram corrosão por fresta, como está mostrado na Figura 39, a seguir, que comprova a influência do feixe laser sobre a superfície deste biomaterial.

Na Figura 39 é mostrada uma fresta formada entre o "o-ring" de borracha utilizado na célula para os ensaios eletroquímicos e a região lateral (borda esquerda) da marcação por feixe laser.

Nesta região, por apresentar aeração diferencial, justifica-se o surgimento da fresta devido à rugosidade produzida pelo laser, que funde o material, empurrando-o para as zonas adjacentes, gerando regiões com diferentes alturas e profundidades em relação à superfície da amostra; determinando o acesso dos íons de oxigênio. 


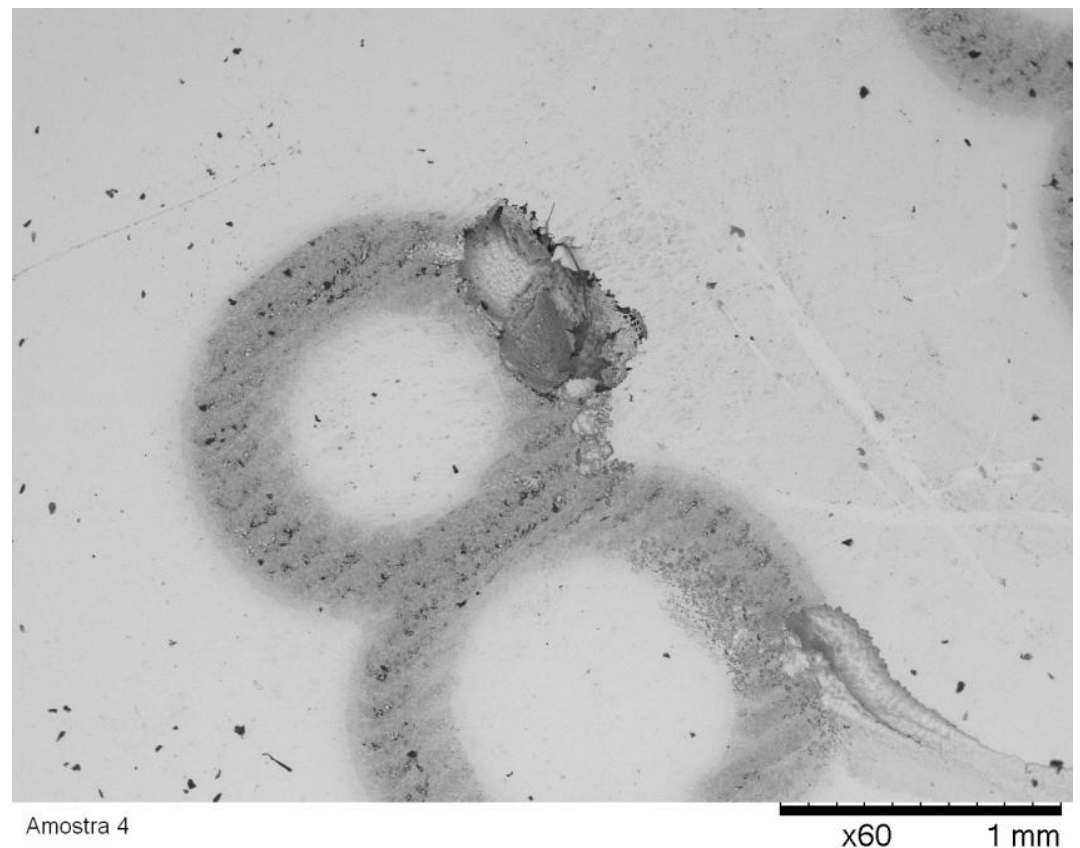

Figura 38 (a). Microscopia eletrônica de varredura do aço inoxidável ABNT NBR ISO 5832-1 com marcação a laser, após o ensaio de polarização cíclica. Aumento: 60x.

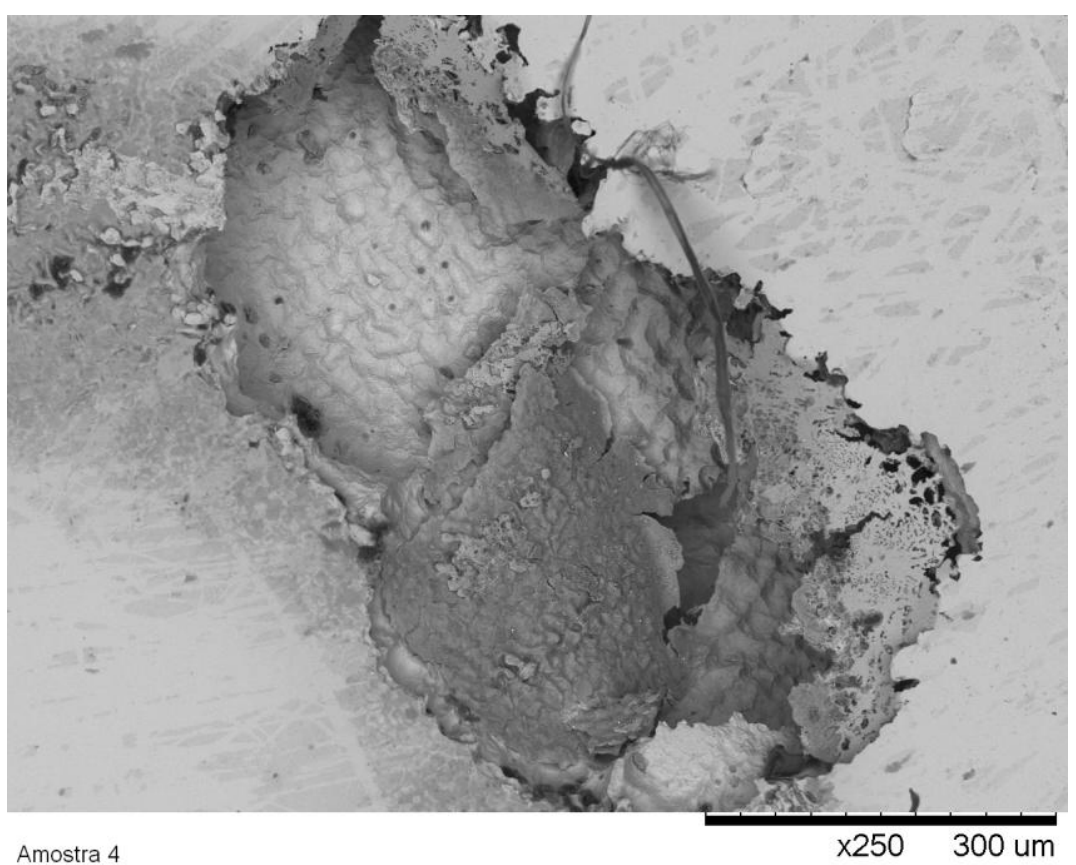

Figura 38 (b). Ampliação do detalhe da Figura 38 (a). Aumento: 250x.

Na Figura 38 (a) nota-se o ataque corrosivo na região da marcação por feixe laser, o que é indesejável, pois com o tempo acaba por danificar a informação contida na gravação. 


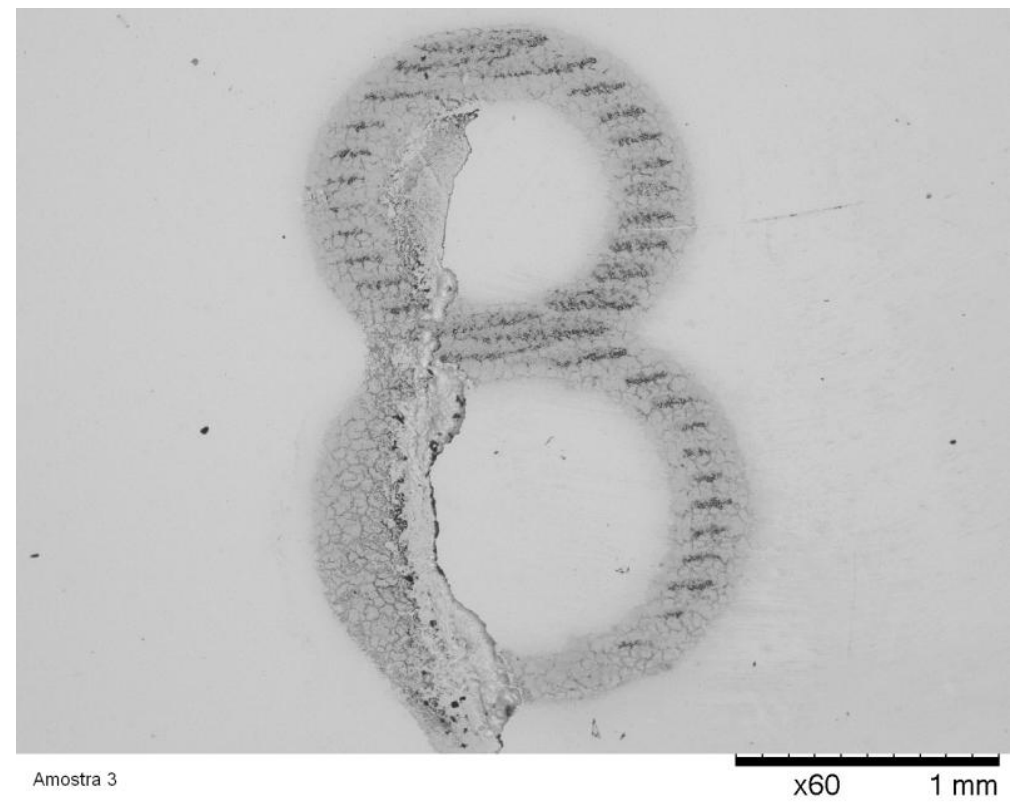

Figura 39. Microscopia eletrônica de varredura mostrando região de fresta formada na borda esquerda na gravação a laser do número oito em uma amostra do aço inoxidável ABNT NBR ISO 5832-1, sem ataque metalográfico. Aumento: 60x.

Conforme já está estabelecido na literatura [5, 24], esta situação causa uma acentuada e localizada queda no $\mathrm{pH}$, tornando a região mais ácida do que em outras áreas e contribuindo para o mecanismo de corrosão.

As amostras sem tratamento a laser também foram avaliadas. Na Figura 40 é mostrada uma imagem de MEV da superfície de uma amostra padrão de referência, sem incidência de laser, que representa as amostras examinadas após polarização cíclica, nas quais pouca ou nenhuma corrosão por pite foi encontrada.

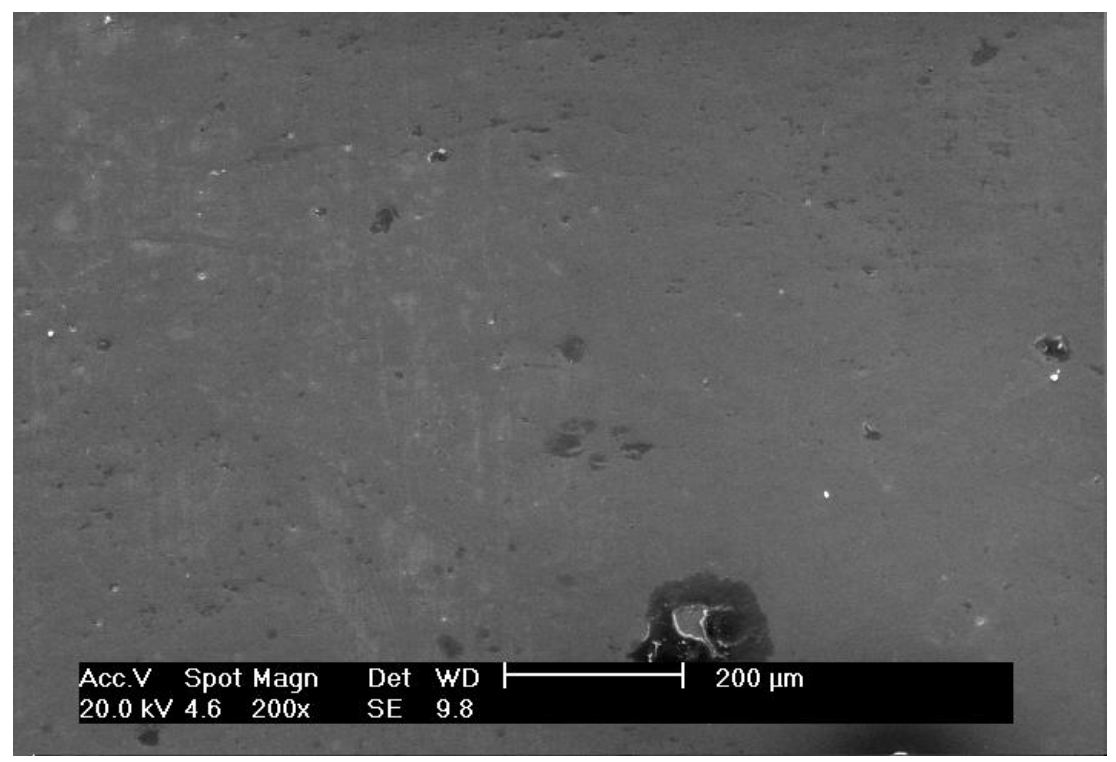

Figura 40. Amostra padrão de referência após polarização potenciodinâmica anódica, sem ataque metalográfico. Aumento: 200x. 
Como pode ser depreendido das curvas de polarização apresentadas anteriormente, as superfícies sem tratamento a laser são mais susceptíveis à corrosão em frestas, conforme as histereses das curvas de polarização indicaram.

Utilizando-se microscopia confocal foi possível obter imagens de pites e frestas nas amostras texturizadas e marcadas a laser e estimar algumas das dimensões destas formas de corrosão, como apresentado nas Figuras 41 e 42.

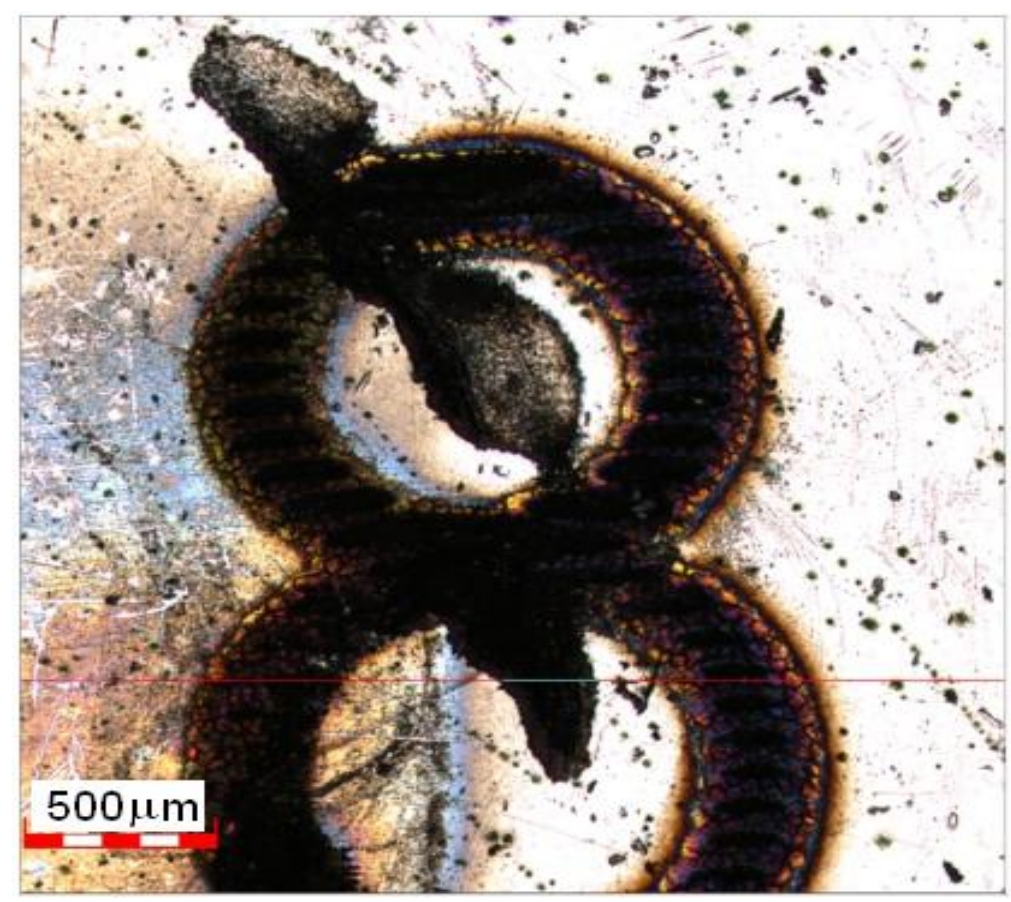

Figura 41. Imagem de fresta formada na amostra-2 com marcação a laser após ensaio de polarização potenciodinâmica anódica, sem ataque metalográfico.

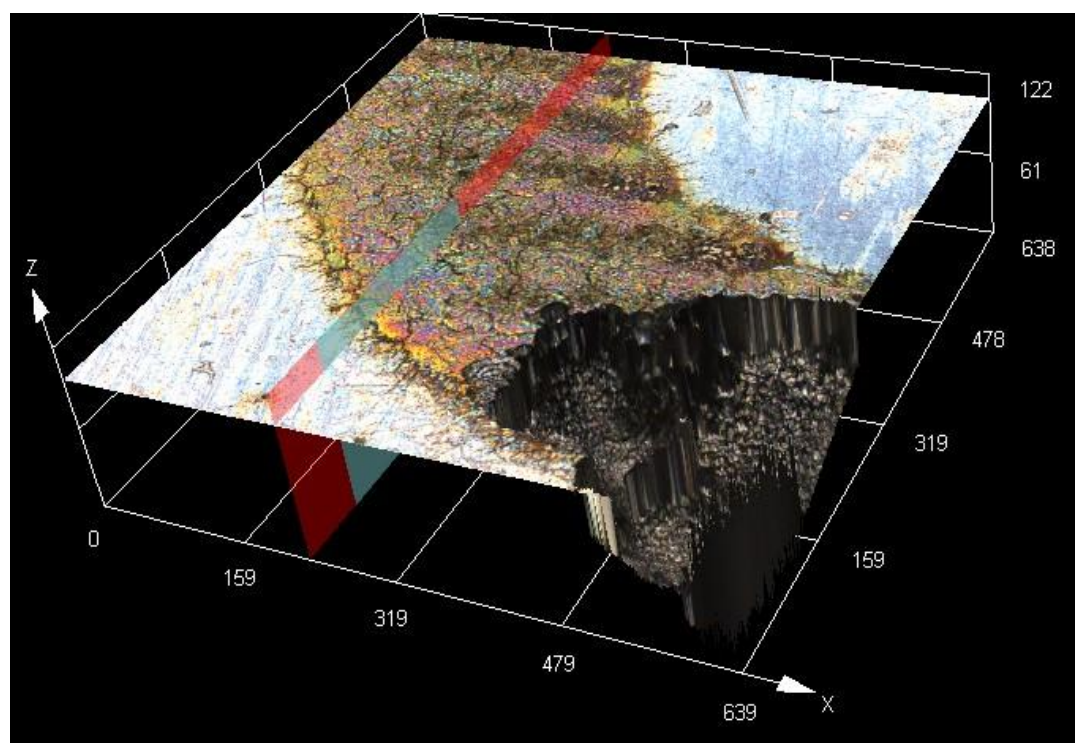

Figura 42. Imagem em 3D de pite formado na amostra-1 com marcação a laser após ensaio de polarização potenciodinâmica anódica, sem ataque metalográfico. 
Nas Figuras 41 e 42 estão apresentadas imagens em 2D e em 3D, de frestas e pites, respectivamente, que surgiram após polarização cíclica nas amostras marcadas por feixe laser, com os parâmetros selecionados. $O$ fato de 0 feixe laser aumentar a área e promover um acabamento superficial menos homogêneo aumenta a susceptibilidade à corrosão do biomaterial.

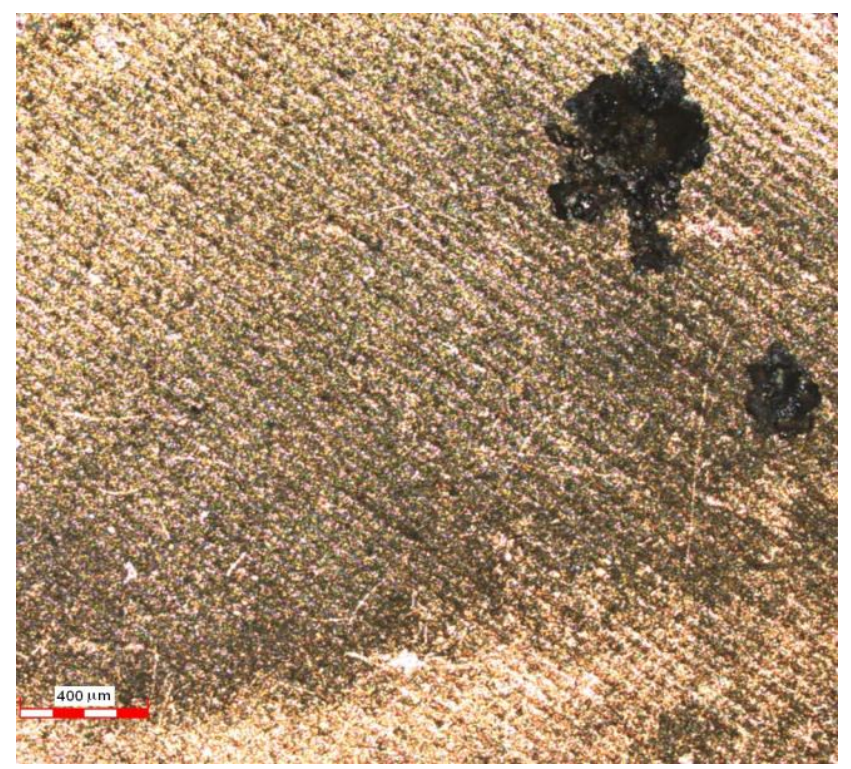

Figura 43. Imagem em de pite formado na amostra-1 com texturização a laser após ensaio de polarização potenciodinâmica anódica, sem ataque metalográfico.

A imagem da Figura 43 mostra pites formados na superfície da amostra texturizada. Por ser a corrosão um fenômeno fortemente dependente da superfície do metal, pode-se concluir que o aumento da área, produzido pelo aumento da rugosidade gerado pela incidência do feixe laser é um dos agentes causadores do surgimento destas formas de corrosão localizada nas superfícies marcadas e texturizadas a laser.

No caso das amostras marcadas a laser há ainda o surgimento de uma interfase de separação das interfaces "lisa", onde não houve incidência do feixe laser e, interface mais rugosa que é a região da marcação. Nota-se em todas as imagens das amostras com marcações que a zona termicamente afetada também é propensa ao aparecimento de corrosão localizada. Nas amostras avaliadas foram encontrados pites e frestas com dimensões da ordem de 70 a $360 \mu \mathrm{m}$ de profundidade e, de 200 a $500 \mu \mathrm{m}$ de largura, chegando a até $2500 \mu \mathrm{m}$ de largura no caso das frestas. 
O surgimento de corrosão por fresta nas amostras tratadas a laser que ocorreu de forma não intencional, pode ser explicado pela condição da superfície que propiciou condições de aeração diferencial. Este fato encontra respaldo na literatura no trabalho de Marcel Pourbaix [84], que aborda um comportamento geral dos biomateriais e não situações específicas como as aqui investigadas. Ele concluiu ser a corrosão por fresta a mais perigosa causa de degradação de biomateriais para implantes.

A influência da rugosidade na resistência à corrosão localizada dos aços inoxidáveis encontra amplo respaldo na literatura. Hong e Nagumo [21] relacionaram esta rugosidade com o número de pites metaestáveis em uma superfície mais lisa ser inferior ao encontrado em superfícies mais rugosas. De acordo com a pesquisa deles, um acabamento superficial mais liso e homogêneo reduz a incidência de pites metaestáveis substancialmente, por reduzir o número de locais capazes de serem ativados no crescimento metaestável dos pites [21].

\subsection{Espectroscopia de Impedância Eletroquímica}

Os diagramas de espectroscopia de impedância eletroquímica (EIE) de Bode (ângulo de fase e módulo de Z) e de Nyquist para os biomateriais nas condições estudadas, obtidos a $37^{\circ} \mathrm{C}$ em solução de PBS, imediatamente após os ensaios de monitoramento de potencial de corrosão em circuito aberto estão apresentados a seguir.

A Figura 44 apresenta o diagrama de Bode (ângulo de fase) para as amostras marcadas a laser e padrão, com os valores de ângulo de fase entre $-35^{\circ}$ e $-80^{\circ}$, na região de baixas frequências, comportamento que corresponde ao de metais passivos [2, 85 - 89], sendo que as amostras sem tratamento por laser apresentaram os menores valores e, os maiores valores foram obtidos para as amostras marcadas na condição 4 .

$\mathrm{O}$ diagrama mostra duas constantes de tempo. Uma delas surge na região de altas frequências, identificada com um ombro entre 0,01 e $0,1 \mathrm{~Hz}$. A outra na de região de baixas frequências, caracterizada por um ombro entre 1 e $10 \mathrm{~Hz}$ para a superfície correspondente à amostra 1 e entre 10 e $100 \mathrm{~Hz}$ para as demais condições de superfícies marcadas (amostras 2, 3 e 4) e sem laser. Este 
comportamento foi observado para aços inoxidáveis e associado à constante em altas frequências à interface óxido externo-meio e, a constante em frequências médias à interface metal-óxido interno [85 - 88].

Os diagramas de Bode (módulo de Z), apresentados na Figura 45, representam a reprodutibilidade obtida nos dez ensaios para cada condição e sugerem que a alteração nos parâmetros do feixe laser utilizados para as marcações tem uma pequena influência na impedância na região de baixas frequências, sendo as mais baixas obtidas para as amostras marcadas nas condições 1 e 4, e as mais altas para o material sem tratamento a laser, nesta faixa de frequências. Este fato evidenciou uma ligeira diminuição na capacidade protetora do filme passivo para as amostras tratadas.

Na Figura 44, os diagramas de Bode (ângulo de fase) mostram um platô estreito para as amostras marcadas a laser em todas as condições avaliadas com valores de ângulo de fase em torno de $-70^{\circ}$, na faixa de médias frequências e, um platô largo com valores de ângulo de fase próximos a -80ำ em uma larga faixa de frequências, de médias a baixas, para as amostras sem tratamento por laser, típico de materiais passivos [2, 85, 86].

Os mais altos ângulos de fase em baixas frequências para as amostras sem marcação sugerem filmes passivos mais protetores. A queda nos ângulos de fase nas mais baixas frequências para as amostras marcadas são indicativas da deterioração das propriedades do filme passivo.

Nas amostras gravadas a laser, o pico de ângulo de fase ocorre em frequências mais baixas em comparação às amostras sem tratamento, sugerindo que a camada mais externa do óxido apresenta-se menos protetora em relação às demais $[1,2,89]$. 


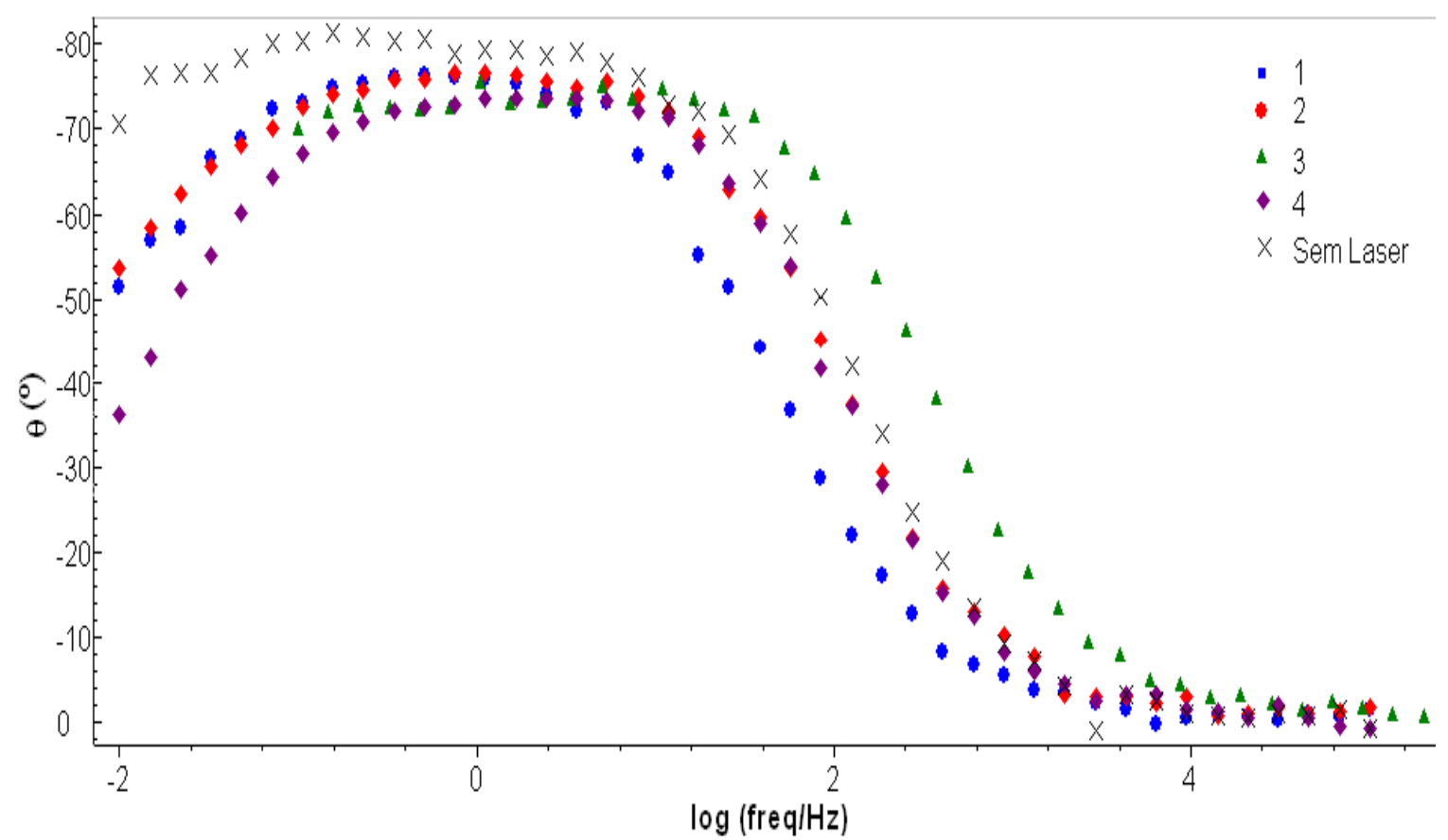

Figura 44. Diagrama de Bode (ângulo de fase) obtido após PCA para o aço inoxidável austenítico ABNT NBR ISO 5832-1em PBS a $37^{\circ} \mathrm{C}$, para as amostras marcadas a laser e padrão.

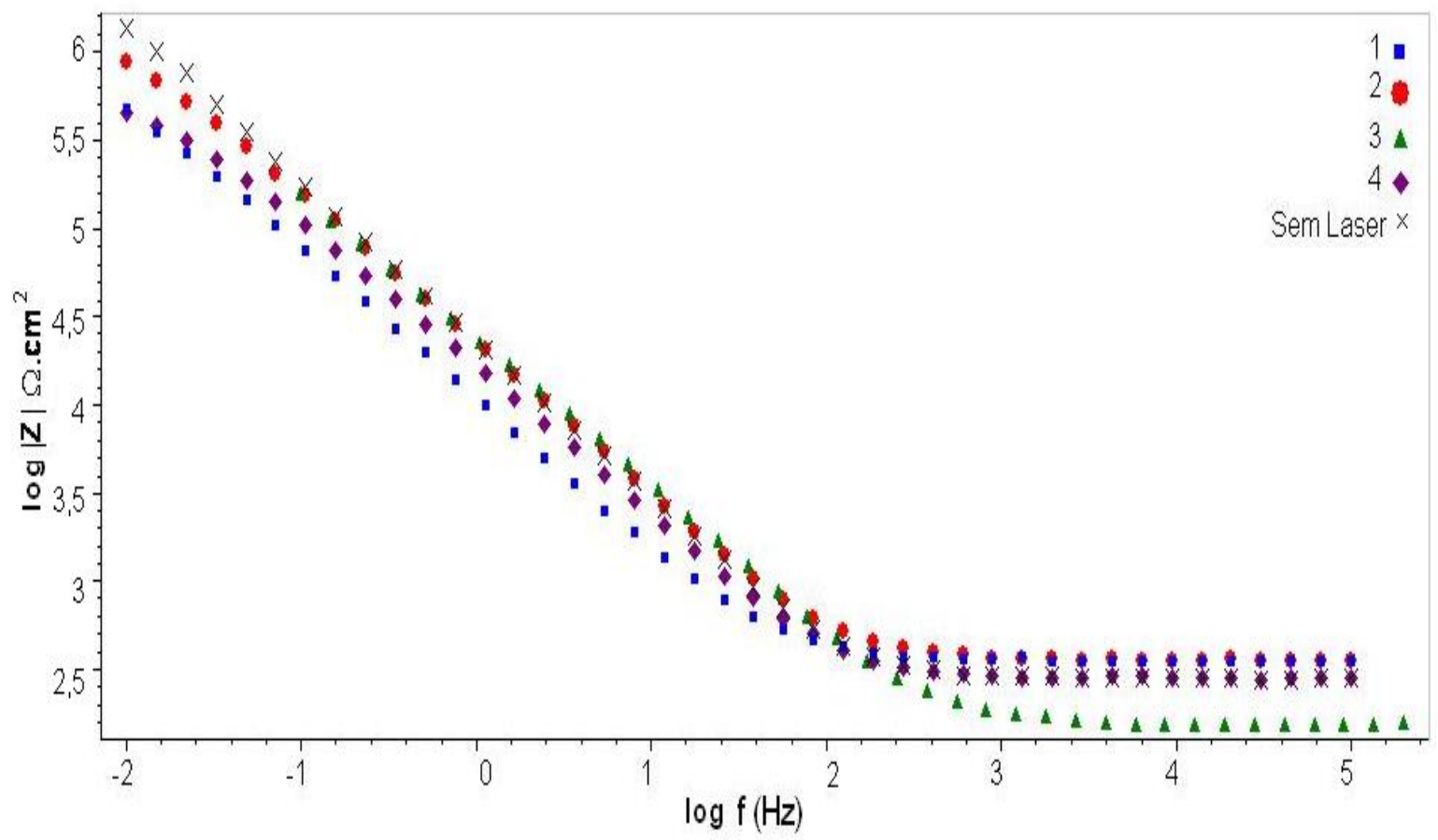

Figura 45. Diagrama de Bode (módulo de Z) obtido após PCA para o aço inoxidável austenítico ABNT NBR ISO $5832-1$ em PBS a $37^{\circ} \mathrm{C}$, para as amostras marcadas a laser e padrão.

A Figura 46 apresenta o diagrama de Bode (ângulo de fase) para as amostras texturizadas a laser e padrão, com os valores de ângulo de fase entre $42^{\circ}$ e $-80^{\circ}$, na região de baixas frequências, comportamento que corresponde ao 
de metais passivos $[88,89]$, sendo que as amostras sem tratamento por laser e texturizadas na condição 2 apresentaram os menores valores e, os maiores valores foram obtidos para as amostras texturizadas na condição 4.

No diagrama estão mostradas duas constantes de tempo. Uma delas surge na região de baixas frequências, identificada com um ombro entre 0,01 e 0,1 Hz. Outra constante é observada na região de médias frequências, caracterizada por um ombro entre 0,1 e $1 \mathrm{~Hz}$ para as superfícies texturizadas a laser correspondentes às amostras 2 e 4, e entre 10 e $100 \mathrm{~Hz}$ para as demais condições de superfícies texturizadas e sem tratamento por laser.

$\mathrm{Na}$ Figura 46, os diagramas de Bode (ângulo de fase) mostram um platô para as amostras texturizadas a laser na condição 1 avaliadas com valores de ângulo de fase em torno de -75ํㅡㄹ na faixa de médias frequências e, um platô com valores de ângulo de fase próximos a $-80^{\circ}$ na faixa de frequências médias, para as amostras sem tratamento por laser, típico de materiais passivos [89].

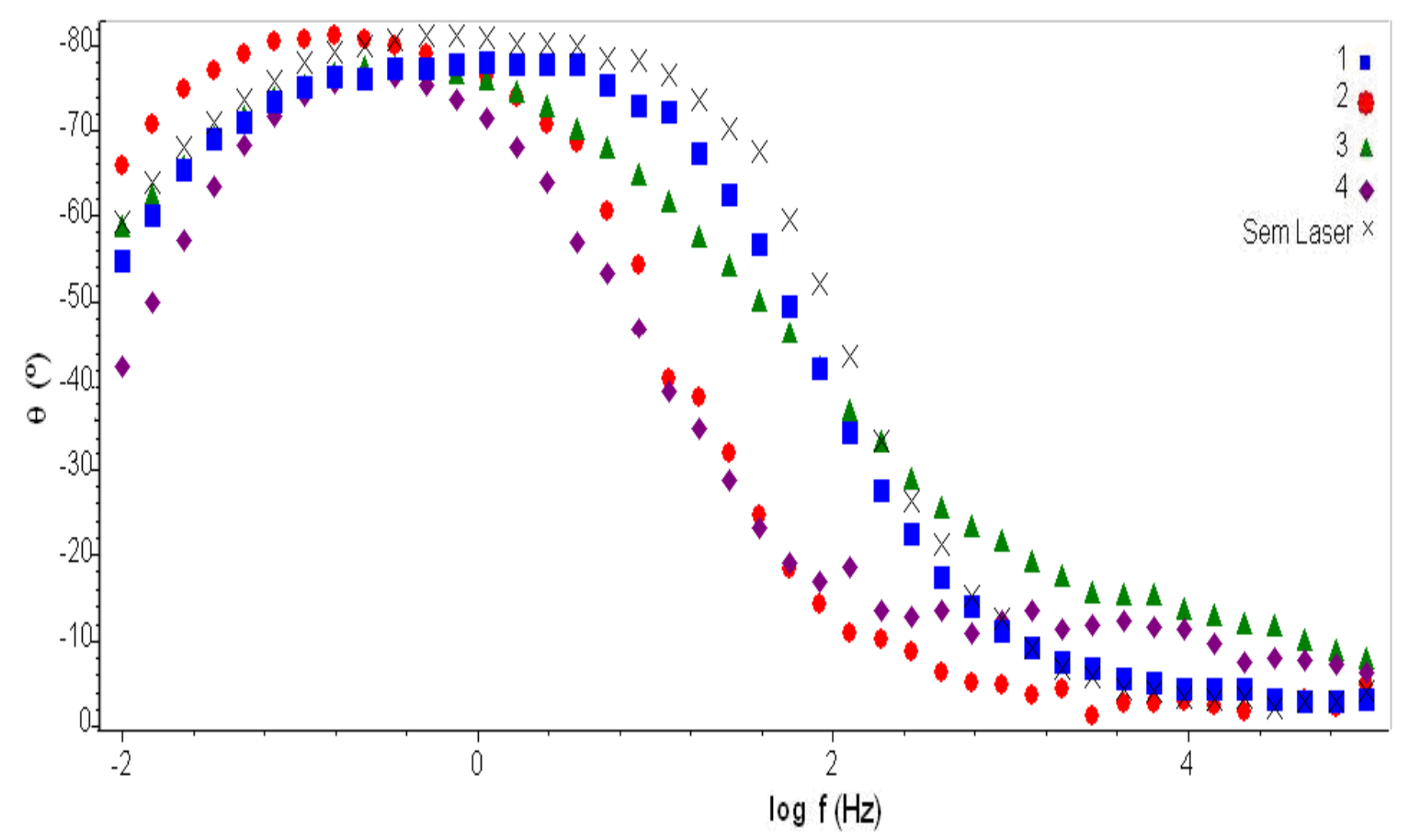

Figura 46. Diagrama de Bode (ângulo de fase) obtido após PCA para o aço inoxidável austenítico ABNT NBR ISO $5832-1$ em PBS a $37^{\circ} \mathrm{C}$, para as amostras texturizadas a laser e padrão.

Os diagramas de Bode (módulo de Z) apresentados na Figura 47, representam a reprodutibilidade obtida nos dez ensaios para cada condição e sugerem que a alteração nos parâmetros do feixe laser utilizados para as 
texturizações influencia na impedância na região de baixas e médias frequências, sendo que as menores foram obtidas para as amostras texturizadas nas condições 2 e 3 , e as mais altas para o material sem tratamento a laser, nesta faixa de frequências. Para as faixas de frequências mais elevadas, os menores valores obtidos corresponderam às amostras nas condições 1 e 4 .

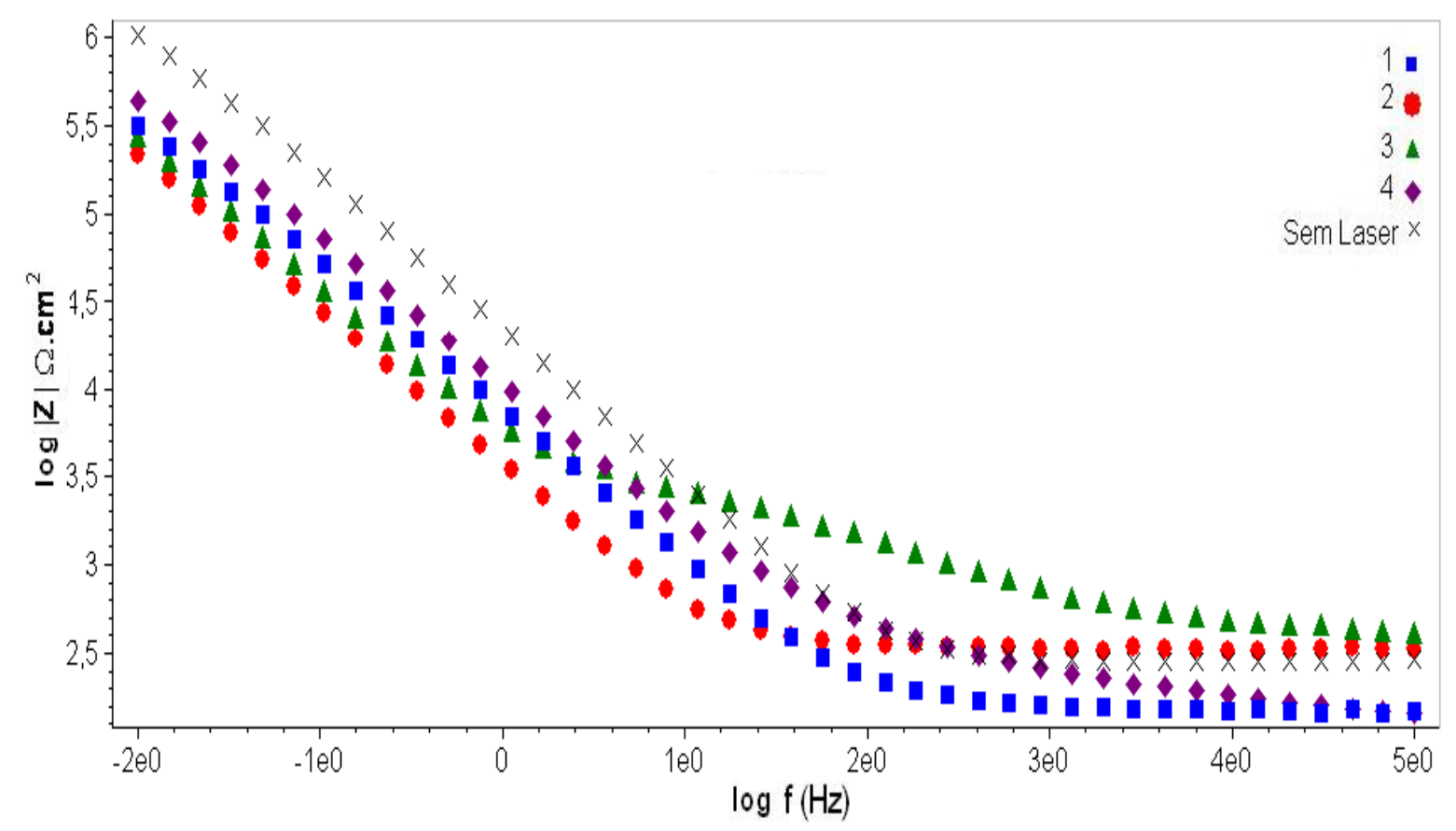

Figura 47. Diagrama de Bode (módulo de Z) obtido após PCA para o aço inoxidável austenítico ABNT NBR ISO $5832-1$ em PBS a $37^{\circ} \mathrm{C}$, para as amostras texturizadas a laser e padrão.

Nas Figuras 48 e 49 são apresentados diagramas de Nyquist com ensaios em cada condição de acabamento superficial, observando-se a reprodutibilidade dos resultados, respectivamente, para as amostras marcadas por feixe laser e texturizadas, comparando-se com a amostra padrão de referência (sem tratamento). Esta tendência foi observada nas dez vezes em que o ensaio foi reproduzido.

Para o mesmo período de imersão a partir do potencial de corrosão em circuito aberto, os diagramas de impedância de Nyquist apresentam comportamento capacitivo, típico de materiais passivos, e mostraram valores de -Zimaginário inferiores para as amostras com tratamento por laser; quando comparadas às amostras de referência, isto é, sem aplicação de feixe laser. 
$\mathrm{Na}$ Figura 48 para um mesmo valor de frequência, as menores impedâncias estiveram associadas à amostra com marcação a laser na condição 3, seguidas das condições de marcação com os parâmetros 4, 1 e 2.

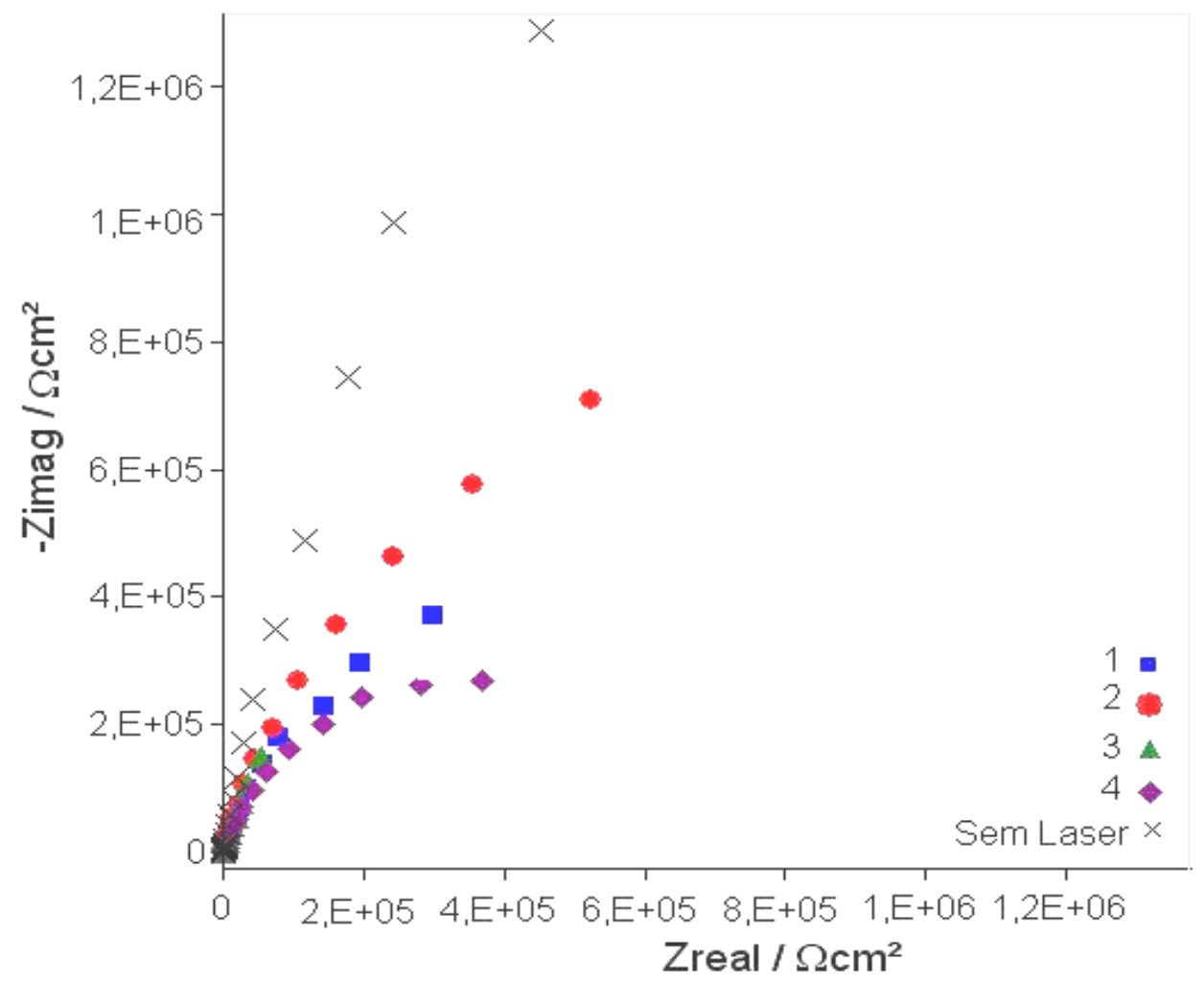

Figura 48. Diagrama de Nyquist obtido após PCA para o aço inoxidável austenítico ABNT NBR ISO $5832-1 \mathrm{em}$ PBS a $37^{\circ} \mathrm{C}$ para as amostras marcadas a laser e padrão.

Para as amostras texturizadas, Figura 49, as menores impedâncias estiveram associadas à amostra com marcação a laser na condição 2 , seguidas das condições de marcação com os parâmetros 3, 1, 4. Em cada diagrama, os últimos pontos referem-se à frequência de $10 \mathrm{mHz}$.

Esta diminuição dos valores de impedâncias para as superfícies tratadas com marcações e texturizações por feixe laser, podem ser explicados, em parte, pelo aumento da rugosidade superficial produzida nestas amostras, uma vez que a formação, crescimento e estabilidade do filme passivo é dificultada [47].

A Figura 49 apresenta diagramas de Nyquist para as amostras das superfícies padrão e texturizadas por laser mostrando impedâncias elevadas associadas às superficies sem tratamento a laser, nas condiçoes utilizadas. 


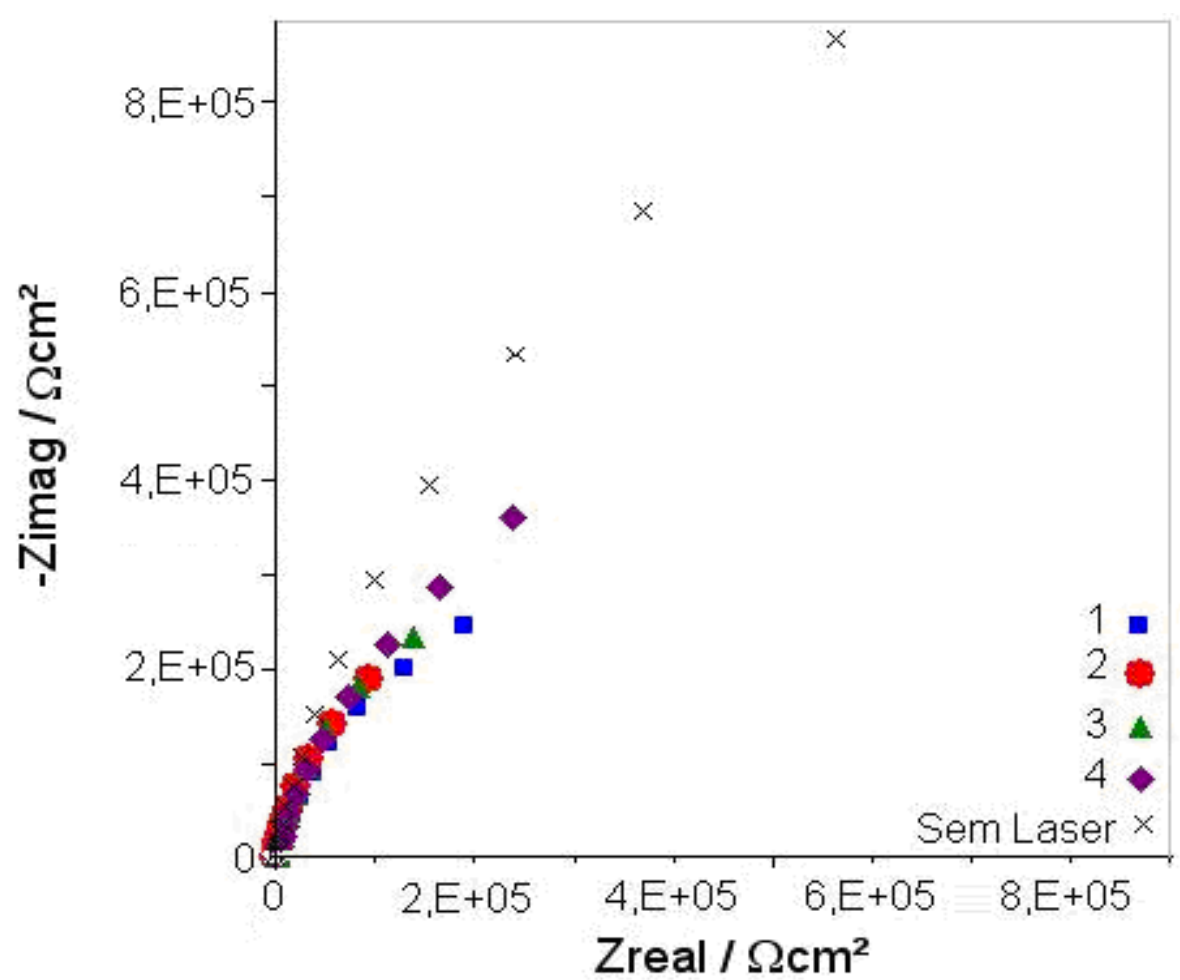

Figura 49. Diagrama de Nyquist obtido após PCA para o aço inoxidável austenítico ABNT NBR ISO $5832-1$ em PBS a $37^{\circ} \mathrm{C}$ para as amostras texturizadas a laser e padrão.

Resultado semelhante foi obtido em pesquisas anteriores para o mesmo biomaterial com tratamento de marcação produzido por feixe de laser de Nd:YAG, pulsado, de nanossegundos, com parâmetros industriais utilizando-se a mesma solução de ensaio, por período de monitoramento de potencial de corrosão em circuito aberto de dezessete horas [1, 2].

O mesmo comportamento foi avaliado neste biomaterial, com e sem marcações a laser em solução contendo elevada concentração de proteínas (albumina) [90, 91].

Os resultados de EIE foram apoiados pelas curvas de polarização potenciodinâmicas cíclicas. As menores resistências à corrosão por pite foram associadas com as amostras tratadas a laser; isto é explicado pelo efeito térmico do processo sobre a homogeneidade da microestrutura deste biomaterial analisado, o que diminui o potencial de quebra da película passiva.

Os circuitos elétricos equivalentes utilizados para ajustar os resultados de espectroscopia de impedância eletroquímica a fim de caracterizar a camada passiva do aço inoxidável utilizado neste estudo nas condições analisadas estão apresentados na Figura 50. 

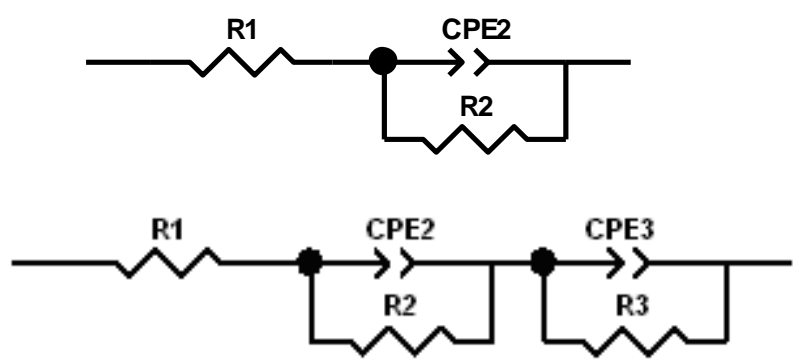

(a)

(b)

Figura 50. Circuitos Elétricos Equivalentes (CEE) utilizados para ajustar os dados experimentais obtidos por EIE para o aço inoxidável austenítico ABNT NBR ISO 5832-1, para as condições: (a) sem marcação e com marcação a laser e (b) com texturização por feixe laser.

Segundo Bonora et al. [60], ao se avaliar um sistema eletroquímico real por espectroscopia de impedância eletroquímica (EIE), prefere-se um elemento de fase constante (CPE) a um capacitor ideal, haja vista a não idealidade de um sistema eletroquímico real.

O ajuste com o circuito apresentado em (a) foi adequado para descrever o comportamento eletroquímico do filme passivo formado sobre o biomaterial metálico sem tratamento a laser e marcado por laser, já o descrito em (b) adequou-se às amostras do biomaterial texturizadas a laser, em todos os casos, por doze horas de imersão em PBS.

Conforme estabelecido na literatura [48 - 53], os filmes passivos formados sobre os aços inoxidáveis apresentam caráter dúplex, possuindo uma região interna rica em óxidos de cromo e uma região externa rica em óxidos e hidróxidos de ferro. Na interface solução / filme passivo, R2 é a resistência da camada externa, composta majoritariamente por óxidos e hidróxidos de ferro.

Os valores dos componentes dos circuitos elétricos equivalentes apresentados acima, ajustados para as condições de acabamento superficial estudadas estão na Tabela 12; CPEs são elementos de fase constante, R1 é a resistência da solução, R2 é a resistência do óxido externo, R3 é a resistência do óxido interno e, $n$ refere-se à potência do CPE. 
Tabela 12. Valores dos parâmetros ajustados utilizando os circuitos mostrados na Figura 50 (a) e (b) para o aço inoxidável austenítico ABNT NBR ISO 5832-1, nas três condições estudadas.

\begin{tabular}{c|c|c|c|c|c|c|c}
\hline & $\begin{array}{c}\mathrm{R} 1 \\
\left(\Omega . \mathrm{cm}^{2}\right)\end{array}$ & $\begin{array}{c}\mathrm{CPE} 2 \\
\left(\mathrm{~cm}^{-2} \mathrm{~s}^{-\mathrm{n}} \Omega\right)\end{array}$ & $\mathrm{n} 2$ & $\begin{array}{c}\mathrm{R} 2 \\
\left(\Omega . \mathrm{cm}^{2}\right)\end{array}$ & $\begin{array}{c}\text { CPE3 } \\
\left(\mathrm{cm}^{-2} \mathrm{~s}^{-\mathrm{n}} \Omega\right)\end{array}$ & $\mathrm{n} 3$ & $\begin{array}{c}\mathrm{R} 3 \\
\left(\Omega . \mathrm{cm}^{2}\right)\end{array}$ \\
\hline Padrão & 170 & $1,51 \times 10^{-5}$ & 0,8884 & $1,44 \times 10^{6}$ & - & - & - \\
\hline Marcas & 225,1 & $3,32 \times 10^{-5}$ & 0,8408 & $7,87 \times 10^{5}$ & - & - & - \\
\hline Texturas & 201,9 & $1,80 \times 10^{-4}$ & 0,4534 & 498,8 & $5,95 \times 10^{-5}$ & 0,8810 & $4,23 \times 10^{5}$ \\
\hline
\end{tabular}

Os menores valores de n2 foram encontrados para as amostras texturizadas, seguidas das amostras com marcações a laser. CPE2 é a capacitância associada à resistência R2, e apresentou valores, para as amostras texturizadas, uma ordem de grandeza superiores aos obtidos nas amostras com marcações a laser e sem laser (padrão), o que indica filmes passivos mais defeituosos para as amostras texturizadas a laser.

A resistência $\mathrm{R} 3$, da camada interna, que é relacionada com os óxidos de cromo, apresentou valores para a amostra texturizada cinco ordens de grandeza superiores aos obtidos para R2, nestas condições, e n3 é a capacitância associada a ela.

Analogamente ao proposto por Patrikar [22], o comportamento apresentado pelas amostras tratadas a laser onde foi evidenciado diminuição na resistência à corrosão, sugere que o acabamento superficial produzido nestes biomateriais implicou em mudanças no comportamento eletrônico dos filmes protetores.

Os diagramas de Bode e de Nyquist mostrando os ajustes utilizando os circuitos apresentados, bem como os erros associados a cada um dos parâmetros do circuito e os valores de chi-quadrado são mostrados no APÊNDICE.

\subsection{Propriedades eletrônicas do filme passivo - Abordagem de Mott- Schottky}

Os resultados apresentados indicam maior susceptibilidade à corrosão localizada nas amostras tratadas por laser, indicando a existência de um filme passivo instável, não homogêneo e defeituoso. 
Devido à necessidade de caracterização da influência da alteração do parâmetro do feixe laser, frequência dos pulsos, apresentados anteriormente e designados por amostra nas condições: 1, 2, 3 e 4 sobre o comportamento do biomaterial frente à corrosão localizada, foi utilizada a abordagem de MottSchottky para se avaliar as propriedades eletrônicas do filme passivo. Na Figura 51 são mostrados gráficos para o aço inoxidável padrão e com marcações a laser.

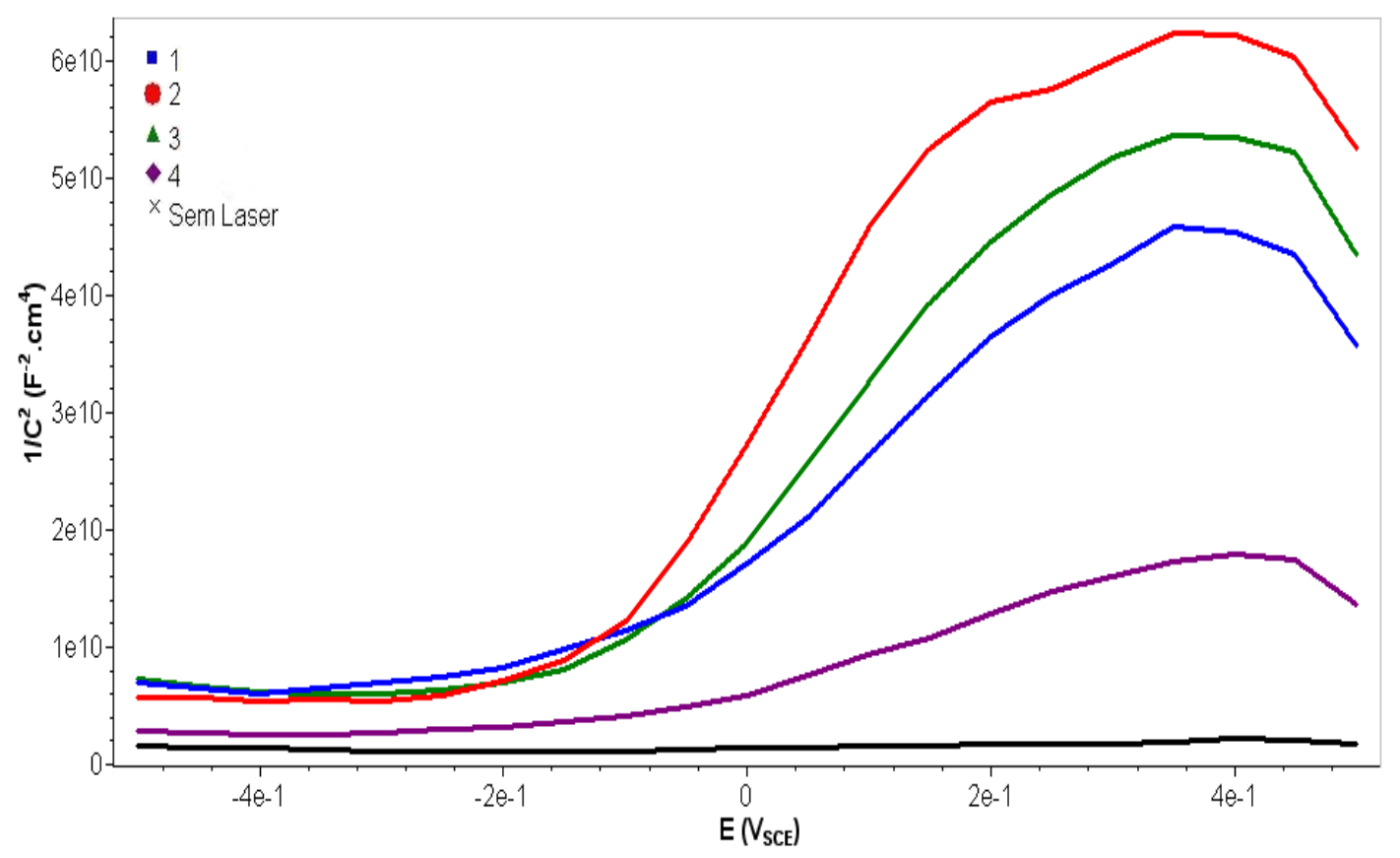

Figura 51. Gráficos de Mott-Schottky para amostras do aço inoxidável austenítico ABNT NBR ISO 5832-1 em PBS, a $37^{\circ} \mathrm{C}$, para amostras marcadas a laser e padrão, imersas por doze horas.

Nos gráficos apresentados nesta seção notam-se diferenças no comportamento dos óxidos de acordo com a condição de acabamento superficial de marcação a laser. As amostras correspondentes ao aço padrão (Figura 51) apresentaram poucas inclinações em toda a faixa de potenciais avaliada.

As amostras marcadas a laser nas condições 1, 2 e 3 apresentaram inclinações elevadas na faixa que compreende a região de potenciais entre $-0,3 \mathrm{~V}$ e + $0,4 \mathrm{~V}$ correspondente ao comportamento de um semicondutor tipo-n (inclinação positiva do gráfico de $1 / C^{2}$ vs. $E$ ), e inclinações mais suaves na região na mesma região de potencias para a amostra 4; o que reflete o caráter dúplex do filme protetor, obtido após o período de imersão de doze horas, conforme a literatura referenciada anteriormente sobre óxidos protetores e suas propriedades eletrônicas utilizando-se a metodologia de Mott-Schottky [48 - 53]. 
Os gráficos de Mott-Schottky mostrados na Figura 52 foram obtidos empregando-se a técnica às amostras texturizadas, na mesma solução de ensaio, período e temperatura mencionados para as amostras marcadas.

Neles verifica-se o comportamento dúplex do filme passivo formado sobre o aço. Acima de $-0,3 \mathrm{~V}$, o gráfico de $1 / \mathrm{C}^{2}$ vs. E apresenta uma inclinação positiva, correspondente ao comportamento de um semicondutor tipo-n, o que de acordo com Hakiki et al. $[48,50]$ está associado à camada externa de óxidos e hidróxidos de ferro nos filmes passivos em aços inoxidáveis. Abaixo deste potencial, o gráfico tende a mudar de inclinação, sugerindo uma tendência de tornar-se negativa, típica de um semicondutor tipo-p, e refere-se à camada interna mais enriquecida em óxido de cromo. $\mathrm{O}$ aço com tratamento de texturização exibiu um caráter dúplex, típico de filmes passivos formados sobre aços inoxidáveis, segundo encontrado na literatura [51, 53].

$\mathrm{Na}$ faixa de potenciais compreendida entre aproximadamente $-0,5 \mathrm{~V}$ e $-0,3 \mathrm{~V}$, que corresponde à inclinação negativa das curvas, foram obtidas inclinações muito suaves, que se relacionam com o comportamento de um semicondutor tipo-p e estão ligadas ao óxido de cromo formado na parte mais interna do filme. Já para os potenciais superiores a $-0,3 \vee$ observaram-se inclinações positivas, porém mais acentuadas, correspondendo à parte mais externa do filme que é basicamente composta por óxidos e hidróxidos de ferro.

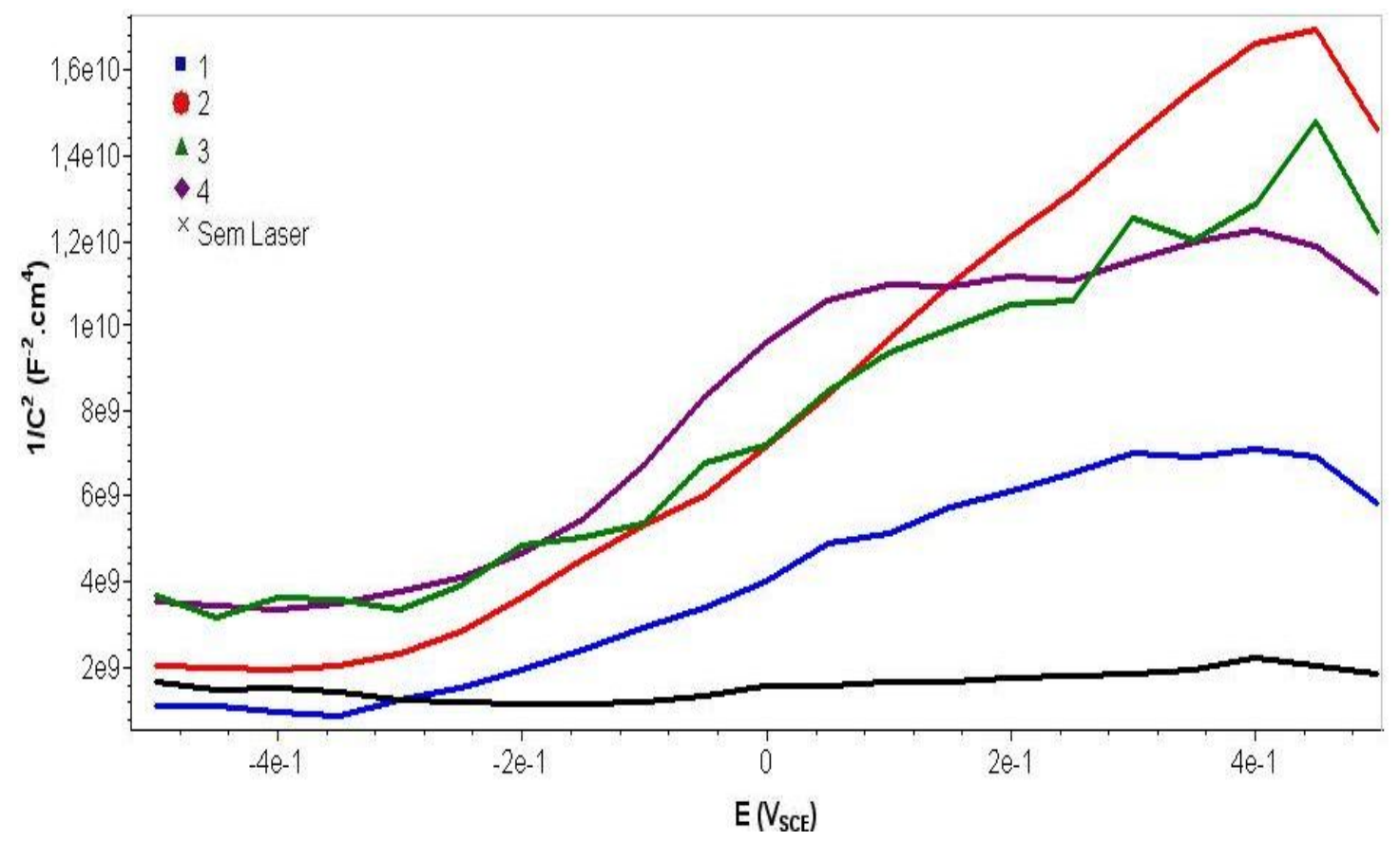

Figura 52. Gráficos de Mott-Schottky do aço inoxidável austenítico ABNT NBR ISO 58321 para amostras texturizadas e padrão, imersas por doze horas em PBS, a $37^{\circ} \mathrm{C}$. 
Analisando-se os gráficos das Figuras 51 a 52 é evidente o efeito causado pelo laser nas propriedades eletrônicas do filme passivo sobre este aço inoxidável utilizado para biomateriais, nas condições de tratamentos realizados por feixe laser. Foi observado que além de mudança na inclinação, também ocorreu deslocamento do potencial de banda plana $\left(E_{b p}\right)$, que como mencionado em seções anteriores, é obtido por meio da extrapolação de $1 / \mathrm{C}^{2}$ para zero. Os resultados para os cálculos de dopantes para todas as condições de superfícies analisadas para este biomaterial estão mostrados nas Figuras 53 a 58.

A Figura 53 mostra que a concentração de doadores de carga, associado a um semicondutor tipo-n para as amostras marcadas a laser e padrão, sendo muito maior para a condição sem tratamento a laser. De acordo com o parâmetro de marcação, estes valores foram maiores para as amostras 1 e 3 .

A Figura 54 mostra a concentração de doadores de carga, associado a um semicondutor tipo-n para as amostras texturizadas a laser e padrão, também sendo muito maior para a condição sem tratamento a laser. De acordo com o parâmetro de texturização, estes valores foram maiores para as amostras 2 e 1 , seguidas das amostras 4 e 3 . A camada externa é a responsável pela interação entre filme passivo (externo) e o eletrólito, que possui os íons halógenos.

Marcação a Laser- Densidade de Doadores $\left(\mathrm{cm}^{3}\right)$

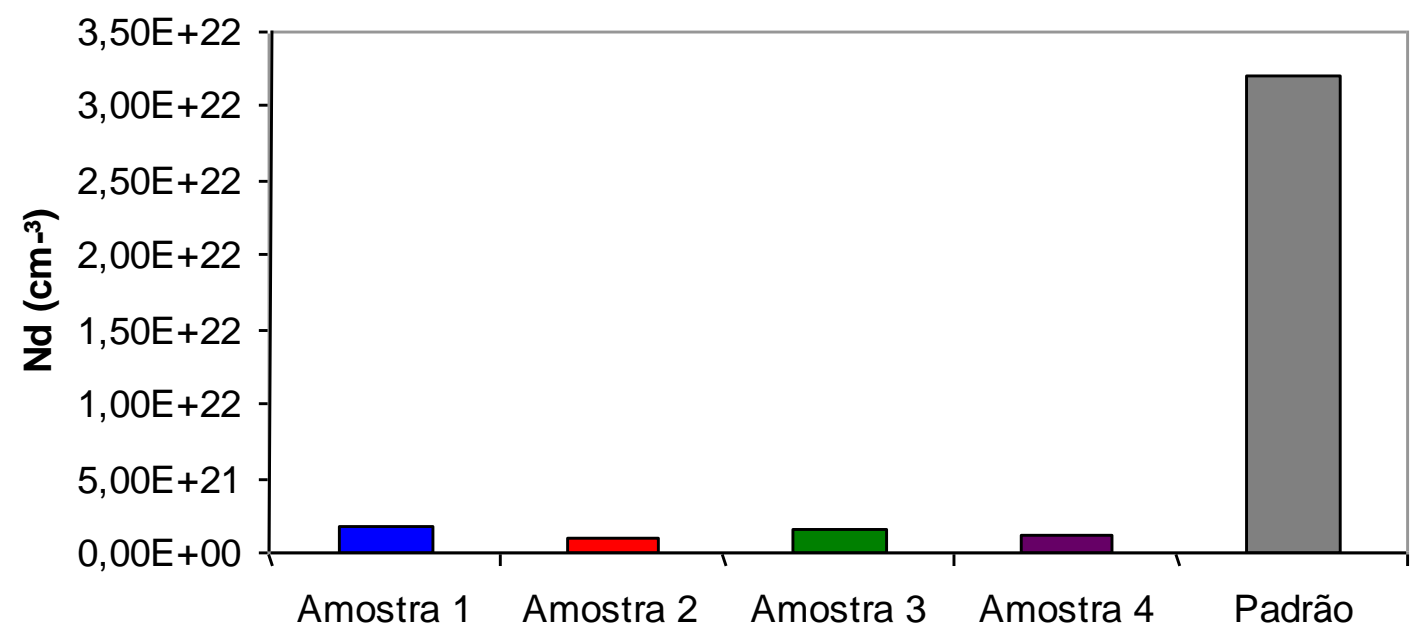

Figura 53. Valores de doadores de carga no filme passivo, obtidos pelo gráfico de MottSchottky, na região de potenciais referentes à inclinação positiva (comportamento de um semicondutor tipo-n) para amostras com marcações a laser. 
Texturização a Laser- Densidade de Doadores $\left(\mathrm{cm}^{-3}\right)$

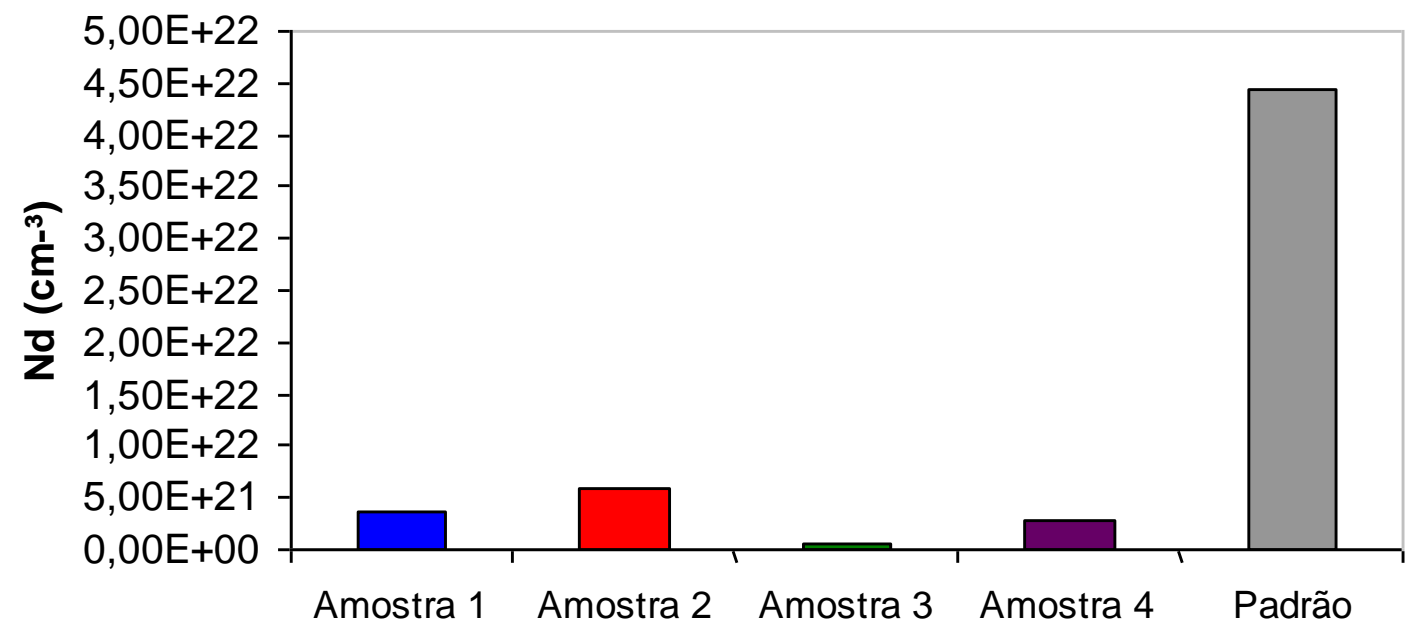

Figura 54. Valores de doadores de carga no filme passivo, obtidos pelo gráfico de MottSchottky, na região de potenciais referentes à inclinação positiva (comportamento de um semicondutor tipo-n), para amostras com texturizações a laser.

Para o mesmo período de imersão, as concentrações de aceitadores de carga no filme passivo das amostras marcadas e texturizadas a laser são distintas dos valores obtidos para os doadores de carga. As Figuras 55 e 56 indicam que os defeitos produzidos afetaram significativamente a camada de óxido mais interna, no caso a rica em cromo.

Marcação a Laser- Densidade de Aceitadores $\left(\mathrm{cm}^{-3}\right)$

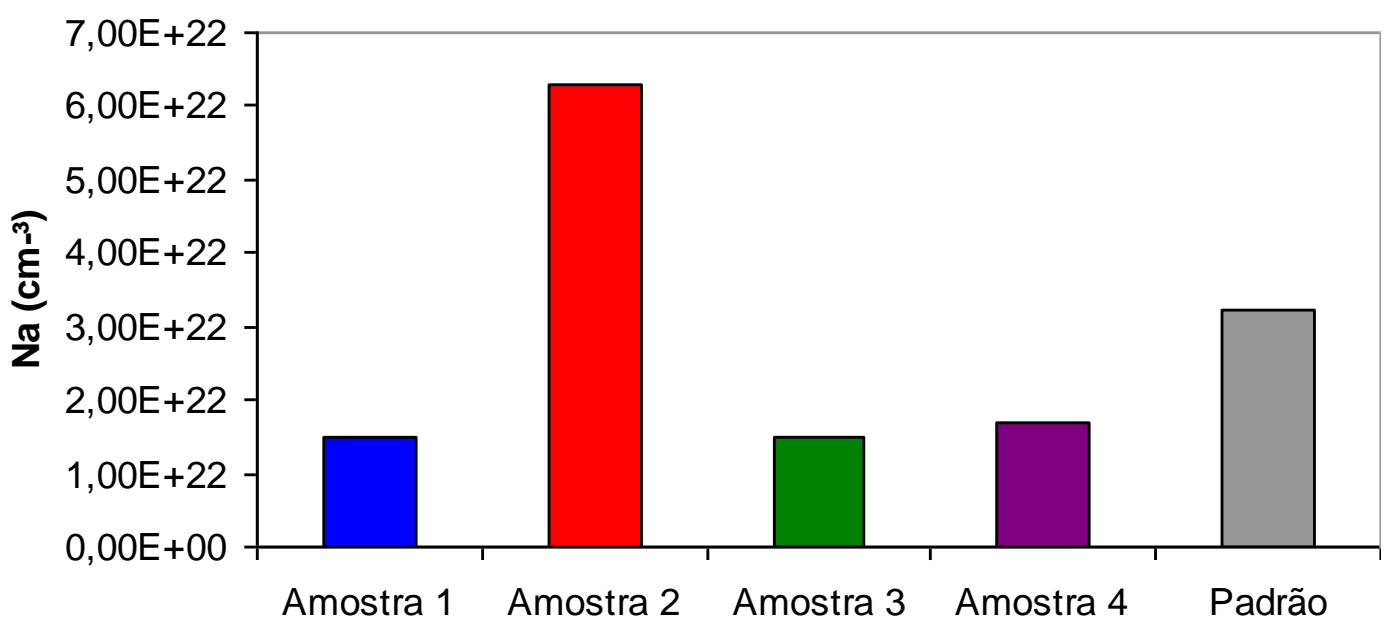

Figura 55. Valores de aceitadores de carga no filme passivo, obtidos pelo gráfico de MottSchottky, na região de potenciais referentes à inclinação negativa (comportamento de um semicondutor tipo-p), para amostras com marcações a laser. 
Texturização a Laser- Densidade de Aceitadores $\left(\mathrm{cm}^{-3}\right)$

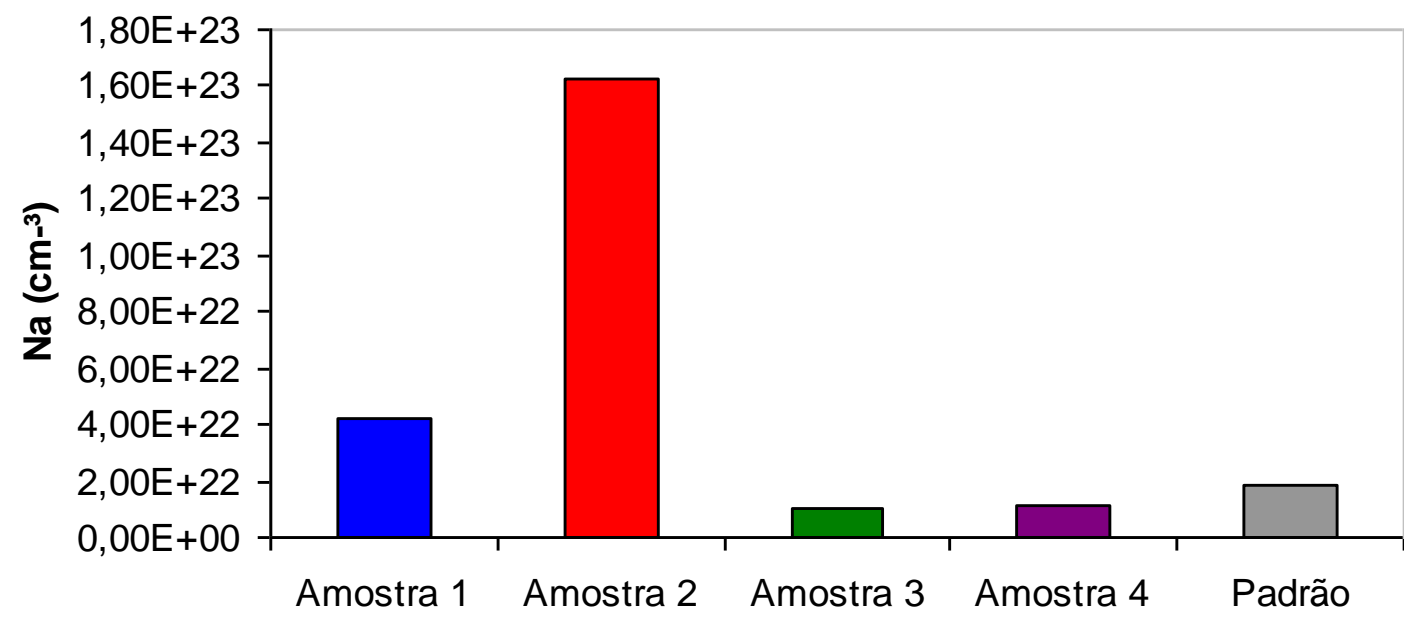

Figura 56. Valores de aceitadores de carga no filme passivo, obtidos pelo gráfico de MottSchottky, na região de potenciais referentes à inclinação negativa (comportamento de um semicondutor tipo-p), para amostras com texturizações a laser e padrão.

Os valores de densidade de dopantes para as amostras marcadas e texturizadas são da ordem de $10^{22} \mathrm{~cm}^{-3}$. Estes valores são superiores à concentração de dopantes encontrada na literatura para este tipo de aço, que é

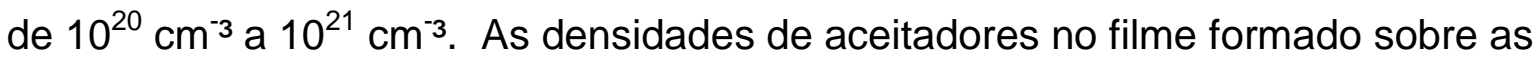
amostras marcadas a laser, foram inferiores à das amostras sem marcações (padrão), exceto na condição da amostra 2. Entretanto, para as amostras texturizadas 1 e 2, tratadas com as menores frequências de pulso, ( $f=80 \mathrm{kHz}$ e $f=188 \mathrm{kHz}$ ), a densidade de aceitadores foi maior do que as demais condições, inclusive a amostra padrão.

Nas Figuras 57 a 58 estão apresentadas as densidades de doadores e aceitadores de cargas, respectivamente, para cada condição de tratamento superficial relacionando à mudança do parâmetro do laser. Estas densidades foram estimadas levando-se em consideração apenas as inclinações posteriores e anteriores ao potencial de banda plana para todas as condições testadas. 


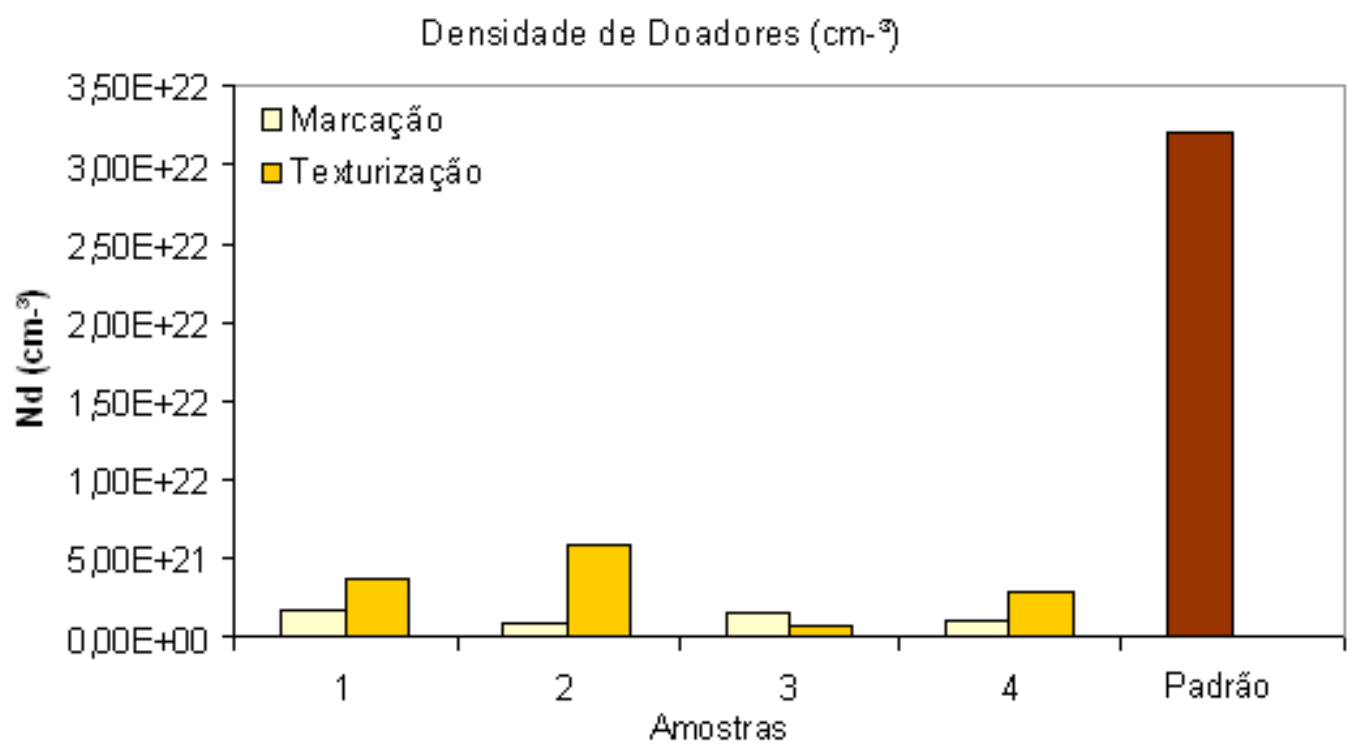

Figura 57. Valores de doadores de carga no filme passivo, obtidos pelo gráfico de MottSchottky, na região de potenciais referentes à inclinação positiva (comportamento de um semicondutor tipo-n), para amostras nas três condições analisadas.

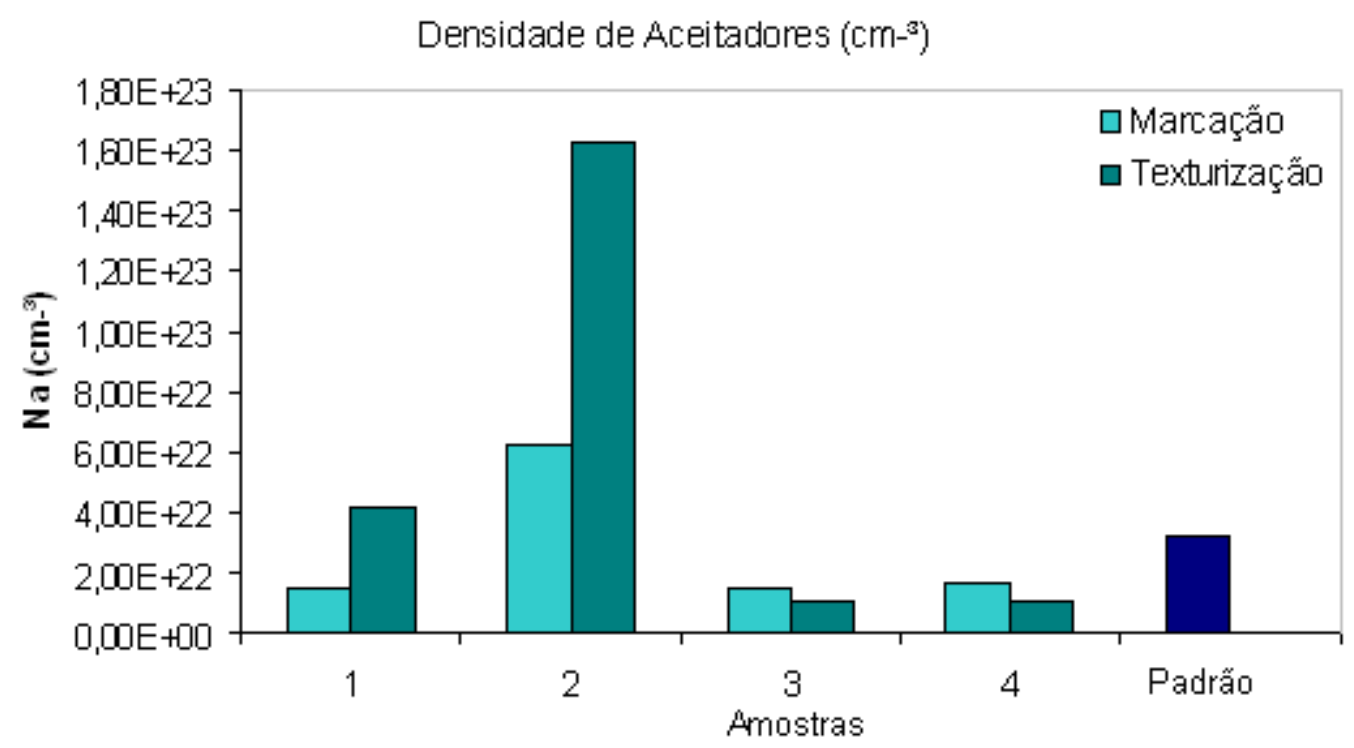

Figura 58. Valores de aceitadores de carga no filme passivo, obtidos pelo gráfico de MottSchottky, na região de potenciais referentes à inclinação negativa (comportamento de um semicondutor tipo-p), para amostras nas três condições analisadas.

Os valores de potenciais de banda plana para cada tipo de amostra para as inclinações negativas e positivas estão apresentados na Tabela 13. 
Tabela 13. Valores de potenciais de banda plana $E_{b p}(V)$ para doadores e aceitadores de carga.

\begin{tabular}{c|c|c}
\hline Amostras & $\begin{array}{c}E_{b p}(\mathrm{~V}) \\
\text { Doadores }\end{array}$ & $\begin{array}{c}E_{b p}(\mathrm{~V}) \\
\text { Aceitadores }\end{array}$ \\
\hline Marcada-1 & $-0,26$ & 0,21 \\
\hline Marcada-2 & $-0,21$ & 2,06 \\
\hline Marcada-3 & $-0,20$ & 0,33 \\
\hline Marcada-4 & $-0,18$ & 0,34 \\
\hline Texturizada-1 & $-0,28$ & 0,22 \\
\hline Texturizada-2 & $-0,33$ & 1,80 \\
\hline Texturizada-3 & $-0,53$ & 0,24 \\
\hline Texturizada-4 & $-0,71$ & 1,65 \\
\hline Padrão & $-0,92$ & 0,50 \\
\hline
\end{tabular}

Os resultados para semicondutores tipo-n (doadores) foram superiores para as condições de texturização nas condições 1, 2 e 4 indicam que os defeitos nesta camada, são provavelmente responsáveis pela maior susceptibilidade à corrosão localizada observada neste tipo de superfície. Esta tem sido relacionada com a camada mais externa do óxido, rica em níquel e ferro [48 -53]. O óxido externo, sendo mais defeituoso, favoreceria o transporte iônico através desta camada do filme, proporcionando o ataque e a quebra da camada interna e o processo de corrosão por pite que se propaga autocataliticamente.

Os resultados para semicondutores tipo-p (aceitadores) foram superiores para as condições de texturização nas condições 1 e 2 e para as amostras marcadas nas condições 3 e 4 . Este fato está relacionado com densidade de defeitos eletrônicos na camada mais interna dos óxidos, relacionadas principalmente com óxidos de cromo.

Hakiki et al. [50], estudaram a estrutura eletrônica dos filmes passivos formados sobre o aço inoxidável AISI 304 por meio da abordagem de MottSchottky apoiada por espectroscopia de elétrons Auger. Foi constatada a influência do cromo sobre o comportamento da capacitância do referido aço inoxidável. Aumentando-se o teor de cromo, a inclinação das curvas de capacitância que respondiam como um semicondutor do tipo-p também aumentava; o que concorda com o fato do filme passivo apresentar caráter 
dúplex, sendo formado por regiões mais internas formadas por óxidos de cromo e, externas, formadas por óxidos e hidróxidos de ferro; possibilitando a comparação do filme passivo com uma heterojunção $p$-n.

De forma semelhante, Feng et al. [92] avaliaram as propriedades semicondutoras do filme passivo formado sobre o aço inoxidável austenítico $316 \mathrm{~L}$ em solução de borato tamponada de $\mathrm{pH} 9,0$ a $22^{\circ} \mathrm{C}$, utilizando a abordagem de Mott-Schottky, espectrometria de absorção atômica e técnicas de XPS para análise de composição química. Os resultados de espectroscopia de impedância eletroquímica foram apresentados pelos diagramas de Nyquist e de Bode (log de Z) e ajustados com circuitos elétricos equivalentes (CEEs). Os valores obtidos para as densidades de defeitos nos óxidos levaram em consideração o efeito da área analisada.

Para as amostras tratadas por marcação e texturização a laser o efeito da área não foi utilizado no cálculo de densidades de dopantes nos filmes passivos formados nas superficies deste biomaterial. Este efeito pode explicar, em parte, os resultados obtidos pela técnica de Mott-Schottky para amostras com marcações e texturizações a laser, por estas apresentarem maior rugosidade superficial, o que aumenta efetivamente a área analisada.

Os valores muito baixos de resistência e elevados de capacitância, associados à camada mais externa, conforme indicado pelos resultados de espectroscopia de impedância eletroquímica para as amostras texturizadas, mostrados na Tabela 12, confirmam estas hipóteses.

Vale ressaltar que não foi encontrado na literatura nenhum trabalho que tivesse utilizado esta abordagem para analisar biomateriais com texturizações e marcações variando-se os parâmetros da frequência dos pulsos de feixe laser de fibra óptica; sendo, portanto esta uma contribuição original deste estudo.

\subsection{Caracterização do Filme Passivo por Espectroscopia de Fotoelétrons Excitados por Raios X (XPS)}

A técnica de espectroscopia de fotoelétrons excitados por raios X (XPS) foi utilizada para se determinar a composição química dos filmes passivos formados sobre as superfícies das amostras deste biomaterial tratados via texturização por 
feixe laser, nas condições mencionadas anteriormente e na condição padrão. Foram realizados "snapshots" para caracterização de distribuição de elementos presentes em área de 2,0 mm² e "Survey" em pontos aleatoriamente distribuídos na superfície. A Figura 59 apresenta um espectro obtido para a amostra na condição padrão. Na Figura 60 encontram-se os resultados qualitativos de snapshots para os elementos: $\mathrm{Ni}, \mathrm{Mo}, \mathrm{N}, \mathrm{O}, \mathrm{Mn}, \mathrm{Fe}, \mathrm{Cr}$ e $\mathrm{Si}$, obtidos após sputtering de 2 minutos com feixe de íons de argônio. Na Figura 60 estão apresentados os valores obtidos apenas para a análise de XPS da amostra 1. Nestas imagens cada 'quadradinho' representa 1 pixel. Os resultados para as demais condições, ou seja, amostras 2, 3 e 4 encontram-se no APÊNDICE.

Para a mesma área avaliada são representados em gráficos de barras os resultados de distribuição de composição química obtidas nos filmes passivos, em função das distâncias analisadas para cada condição de amostra. Para efeito de comparação entre os acabamentos superficiais das amostras, os elementos foram fixados e, cada gráfico de barras representa a variação de contagens do elemento em função do parâmetro da amostra, estes resultados também se encontram no APÊNDICE.

Com o intuito de se caracterizar quantitativamente os filmes passivos formados sobre as superficies deste biomaterial nas condições padrão e texturizadas por feixe laser com os parâmetros estipulados, as amostras foram avaliadas por XPS pelo método Survey em diferentes pontos distribuídos aleatóriamente.

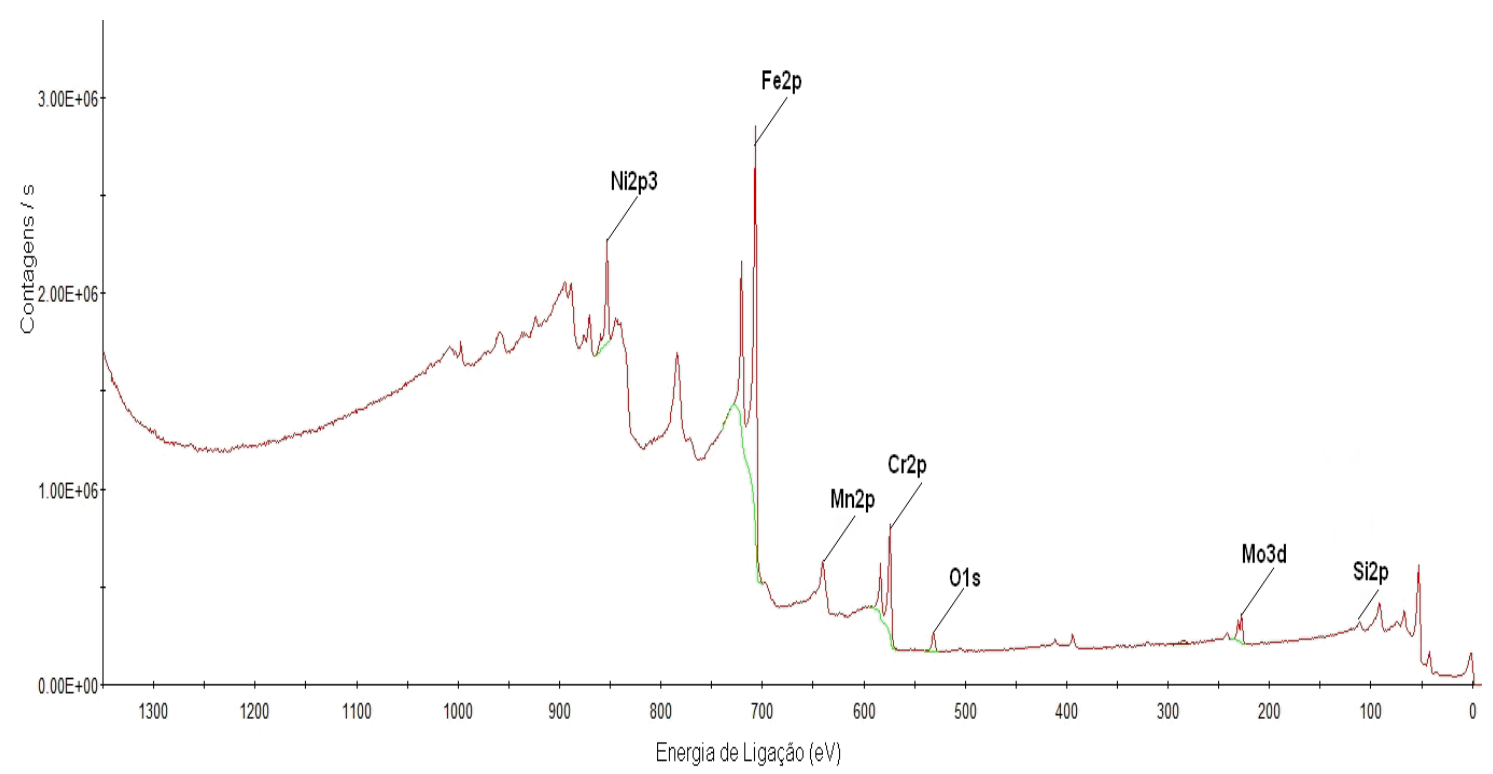

Figura 59. Espectro de XPS da amostra padrão. 
$\mathrm{Ni} 2 \mathrm{p}$ Snap A1

(846.479 eV) Counts/s

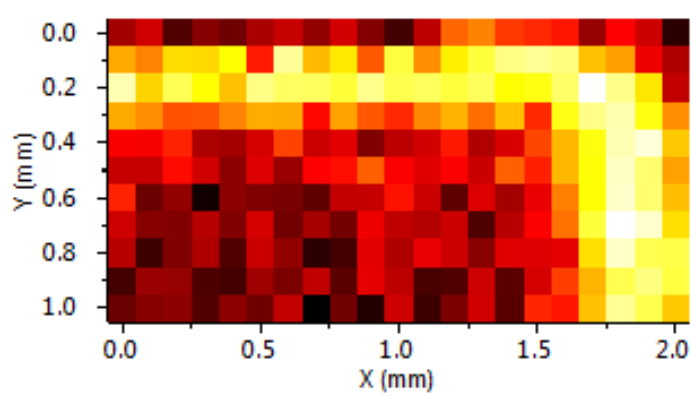

N1s Snap A1 $(392.479 \mathrm{eV})$ Counts/s

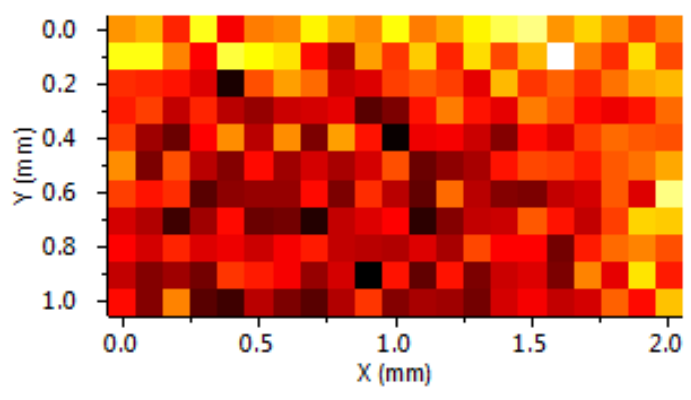

Mn2p Snap A1 (632.279 eV) Counts/s

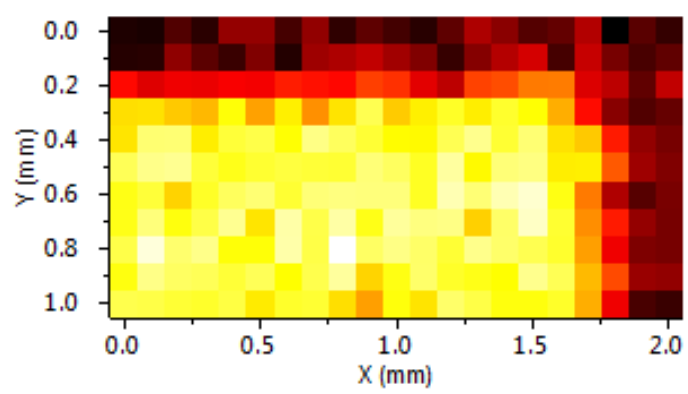

Cr2p Snap A1 (567.779 eV) Counts/s

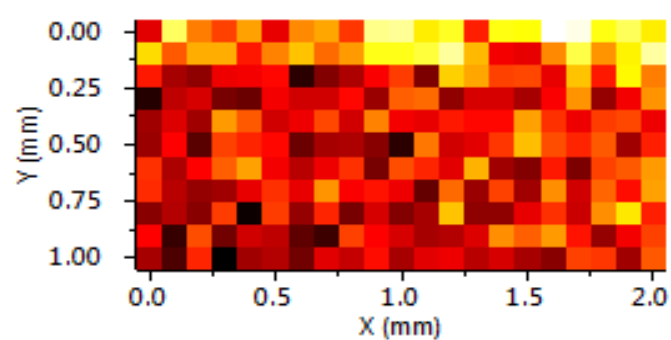

220

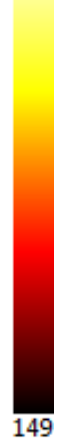

30.7

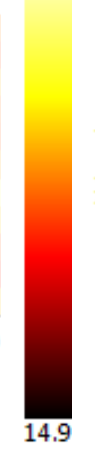

111

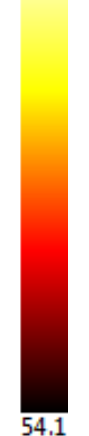

65.5

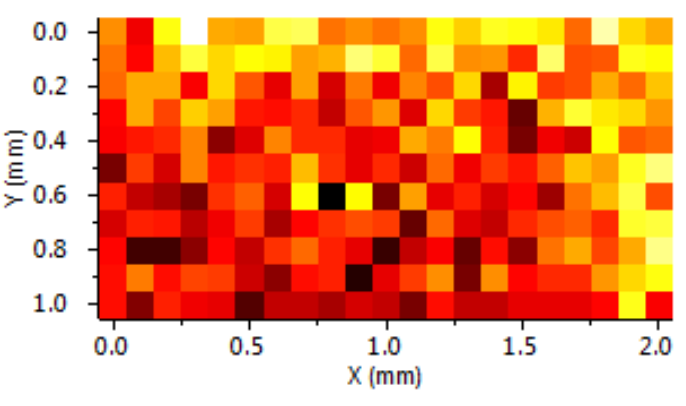

O1s Snap A1 (524.479 eV) Counts/s

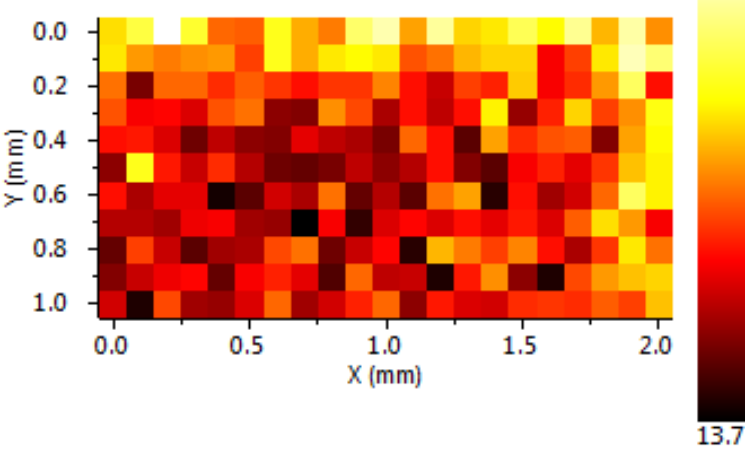

Fe2p Snap A1 (700.379 eV) Counts/s

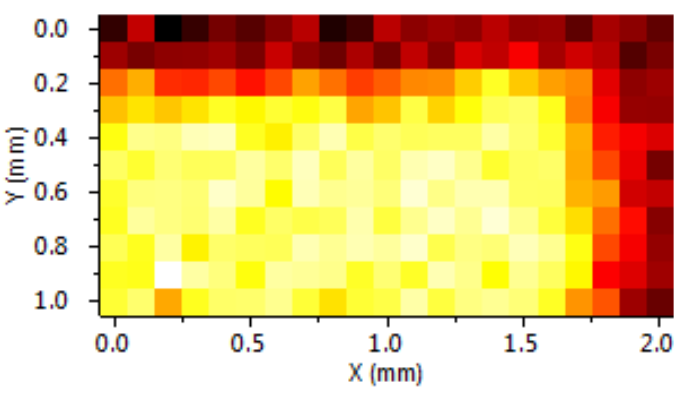

Si2p Snap A1 $(95.979 \mathrm{eV})$ Counts/s

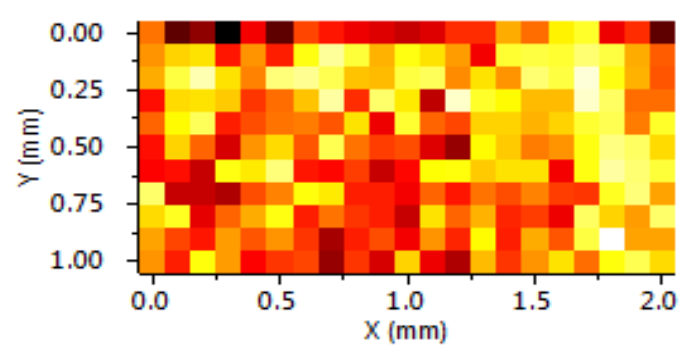

Figura 60. Distribuição de elementos químicos presentes em área de 2,0 $\mathrm{mm}^{2}$ do filme passivo formado na superfície da amostra 1, obtido por XPS. 
$\mathrm{Na}$ Tabela 14 estão apresentados os resultados quantitativos de porcentagem atômica (\%) dos elementos químicos encontrados nas superfícies das amostras analisadas.

Tabela 14. Composição química (\% atômica), obtidas por XPS, das superfícies das amostras texturizadas e padrão.

\begin{tabular}{c|c|c|c|c|c}
\hline Amostras/elementos & 1 & 2 & 3 & 4 & Padrão \\
\hline $\mathrm{Fe}$ & 34,46 & 54,18 & 45,21 & 34,15 & 63,76 \\
\hline $\mathrm{Cr}$ & 40,34 & 31,14 & 32,36 & 35,46 & 18,72 \\
\hline $\mathrm{Mn}$ & 25,20 & 14,68 & 22,43 & 30,39 & 2,19 \\
\hline $\mathrm{Ni}$ & - & - & - & - & 12,38 \\
\hline $\mathrm{Mo}$ & - & - & - & - & 2,95 \\
\hline
\end{tabular}

Para efeito de cálculo foram utilizados os elementos majoritários que compõem a liga do aço inoxidável austenítico usado como biomaterial. Portanto o elemento silício foi desconsiderado. Os teores de oxigênio encontrados foram inferiores a 6\%. Na amostra padrão foram encontrados teores significativos de níquel e molibdênio; entretanto, para as amostras texturizadas a laser estes elementos não foram detectados ou apresentaram número de contagens irrisória, portanto foram desconsiderados e o valor total dos cálculos das porcentagens foi arredondado para $100 \%$.

Verificam-se aumentos expressivos nos teores de manganês e cromo nas superfícies enquanto ocorre diminuição nos teores de ferro para todas as condições de amostras texturizadas em relação à amostra padrão. No caso da amostra 1, o teor do elemento cromo é duplicado enquanto que o de manganês aumenta em cerca de 11 vezes e o teor de ferro diminui praticamente $50 \%$.

Comportamento semelhante foi evidenciado por análises de espectroscopia de energia dispersiva de caráter qualitativas e semi-quantitativas por EDSQUANTA via SEM-FEG, que serão mostradas a seguir.

\subsection{Análises por Ativação Neutrônica}

A técnica de ativação neutrônica foi empregada para se avaliar características do filme passivo. Ao término dos ensaios eletroquímicos foram 
recolhidos extratos de cerca de $40 \mathrm{~mL}$ da solução de PBS utilizada para simular os fluidos corpóreos. Todas as amostras avaliadas por esta técnica ficaram imersas por um período de 15 horas nesta solução. O objetivo foi o de se determinar a concentração dos elementos químicos presentes nos óxidos que se desprendeu de cada amostra e migrou para a solução, permitindo-se desta maneira o conhecimento de quantidades de elementos químicos do filme passivo que foi deteriorado ao término dos ensaios eletroquímicos. Os resultados obtidos encontram-se na Tabela 15. Os valores estão apresentados em $[\mu \mathrm{g} / \mathrm{mL}]$.

Tabela 15. Determinação de elementos químicos em amostras de extratos de solução de PBS após polarização cíclica pelo método de análise por ativação com nêutrons.

\begin{tabular}{c|c|c|c|c|c}
\hline $\begin{array}{c}\text { Amostra } \backslash \\
\text { elementos }\end{array}$ & 0 & 1 & 2 & 3 & 4 \\
\hline $\mathrm{Cl}$ & $30052 \pm 623$ & $4605 \pm 56$ & $5306 \pm 68$ & $6570 \pm 78$ & $5798 \pm 85$ \\
\hline $\mathrm{K}$ & $<9,6$ & $0,336 \pm 0,058$ & $0,396 \pm 0,055$ & $0,488 \pm 0,085$ & $0,348 \pm 0,031$ \\
\hline $\mathrm{Na}$ & $18410 \pm 35$ & $2755 \pm 5$ & $3470 \pm 5$ & $4800 \pm 7$ & $3215 \pm 5$ \\
\hline $\mathrm{Fe}$ & - & $0,693 \pm 0,077$ & $0,067 \pm 0,058$ & $0,230 \pm 0,080$ & $<0,279$ \\
\hline $\mathrm{Cr}$ & - & $0,031 \pm 0,006$ & $0,054 \pm 0,006$ & $0,247 \pm 0,006$ & $0,058 \pm 0,007$ \\
\hline $\mathrm{Ni}$ & - & $0,870 \pm 0,038$ & $0,215 \pm 0,030$ & $0,677 \pm 0,032$ & $0,205 \pm 0,050$ \\
\hline $\mathrm{Mo}$ & - & $<0,056$ & $<0,08$ & $<0,09$ & $<0,03$ \\
\hline $\mathrm{Mn}$ & - & $<0,16$ & $<0,01$ & $<0,21$ & $<0,13$ \\
\hline
\end{tabular}

A chamada amostra 0 (zero) é a solução de fosfato tamponada, de $\mathrm{pH} 7,4$; de composição química mencionada anteriormente. Os elementos molibdênio e manganês não foram detectados nas condições experimentais utilizadas; portanto os resultados apresentados foram os valores dos limites de detecção. Ficou evidente que a concentração $[\mu \mathrm{g} / \mathrm{mL}]$ dos elementos químicos foi alterada em função do tipo amostra. Entretanto, não foi possível estabelecer uma correlação direta entre a alteração do valor de frequência utilizada na texturização a laser com a quantidade de elementos que foi desprendida dos óxidos formados sobre as superfícies dos biomateriais após os ensaios eletroquímicos e que migrou para a solução, porque outros fatores como o acabamento superficial e efeito de aumento de área são preponderantes. 


\subsection{Características Produzidas pelo Laser na Superfície do Biomaterial}

Com o intuito de se avaliar as características geradas na interação do feixe laser com a matéria (aço inoxidável austenítico ABNT NBR ISO 5832-1) foram realizadas análises qualitativas e semi-quantitativas por EDS-QUANTA via SEMFEG. Este equipamento proporcionou a aquisição de imagens com altíssima resolução e resultados de análises químicas (EDS), das amostras do biomaterial tratado a laser. Os resultados obtidos apresentaram alteração da composição química do aço inoxidável tratado a laser.

As análises de EDS foram extraídas pontualmente e em linha nas amostras tratadas a laser com os parâmetros citados anteriormente e na amostra padrão de referência como está apresentado nas figuras e nos espectros seguintes. Foram avaliadas as regiões marcadas a laser, zona termicamente afetada e regiões distantes da incidência do feixe laser. Existiram alterações significativas relacionadas aos elementos cromo, ferro, manganês, molibdênio e níquel que podem ser observadas comparando-se os espectros de EDS para as diferentes regiões analisadas, que se encontram selecionadas nas figuras seguintes.

Os espectros para as análises pontuais para a amostra tratada nas condições 1 indicaram pouca variação de contagens (\% atômica) para os elementos avaliados. Na distribuição por line scan nota-se que na posição em que houve um aumento de cromo, ocorreu também aumento de oxigênio e diminuição de ferro.

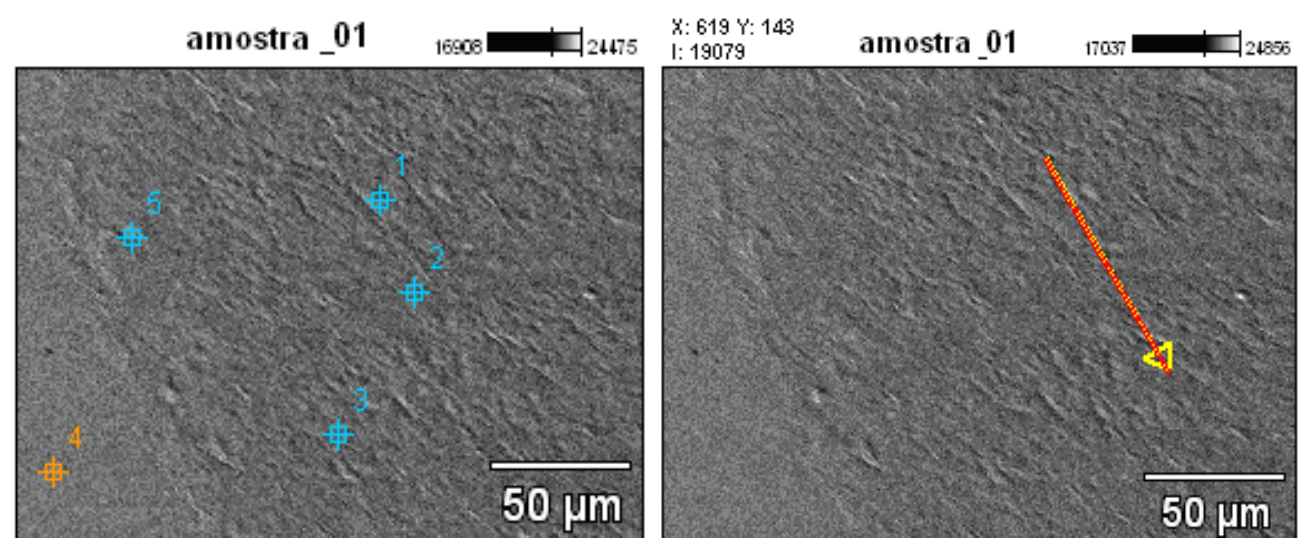

Figura 61. Regiões da amostra-1 analisadas por pontos e por linha, respectivamente. A seta indica o sentido adotado para a análise por "line scan".

Aumento: 500x. Sem ataque. 
Full scale counts: 884

amostra_01_pt1

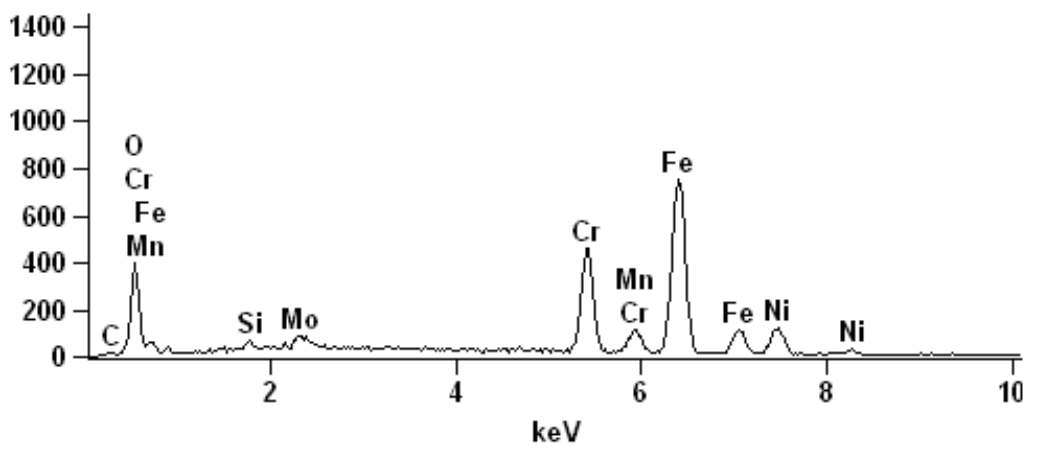

Figura 62. Espectro de EDS para o ponto-1, região da marcação a laser.

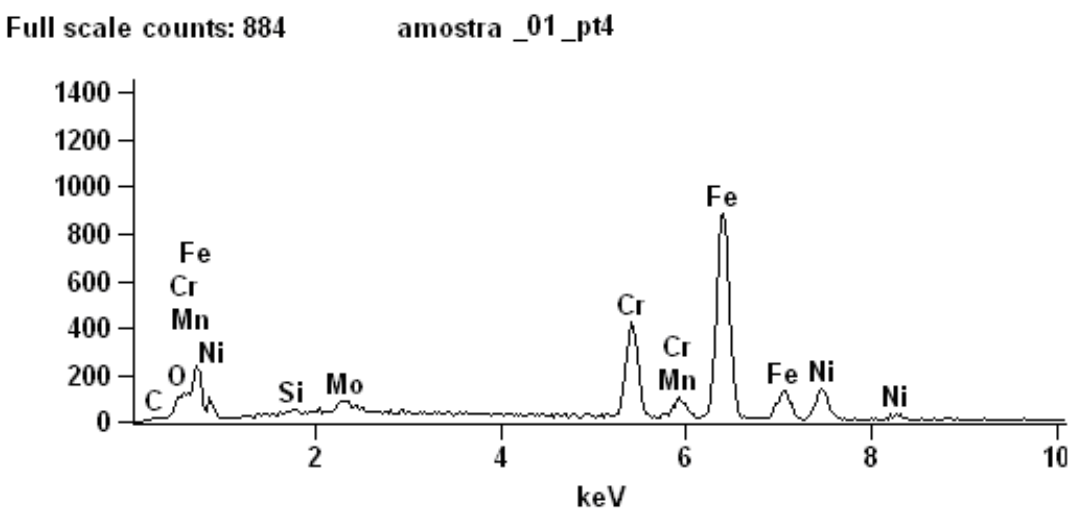

Figura 63. Espectro de EDS para o ponto-4, região sem laser.

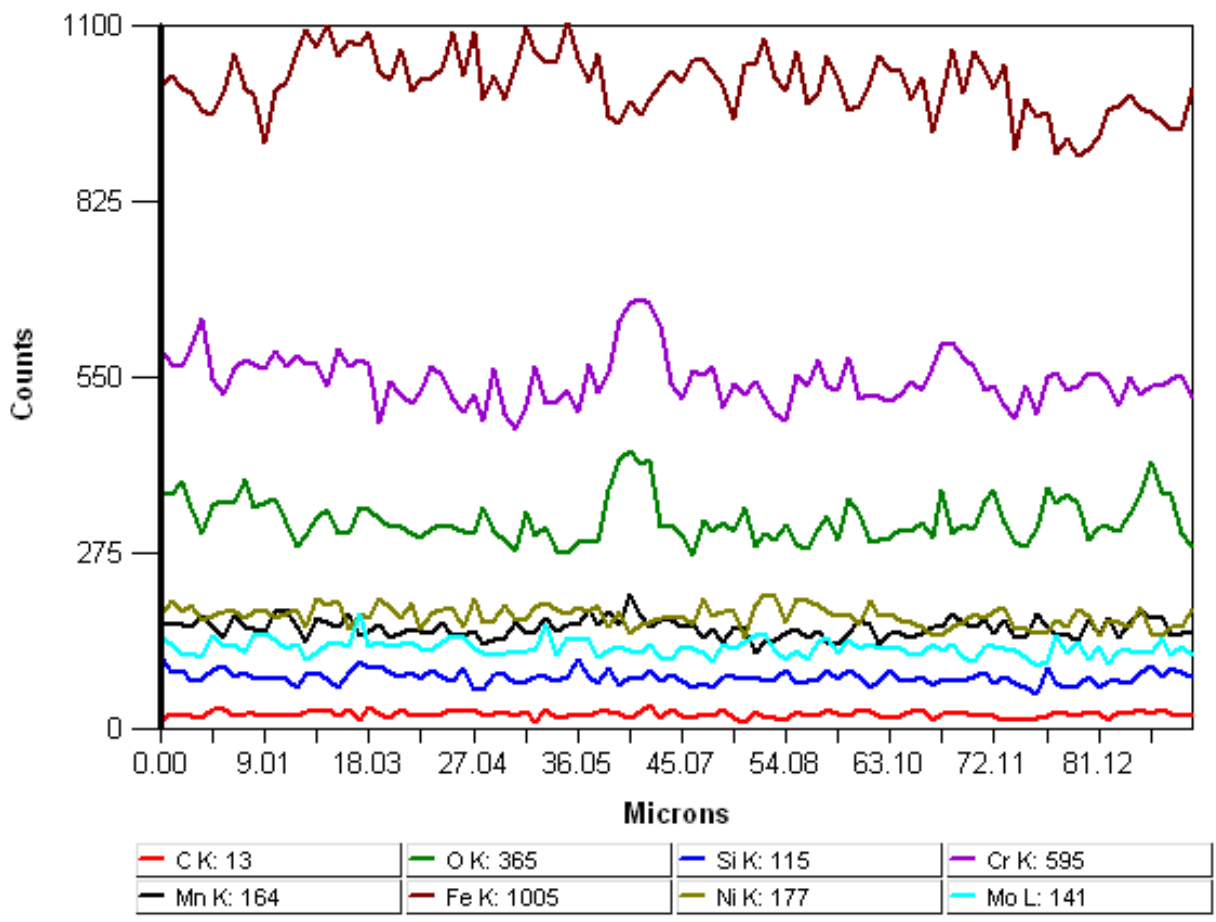

Figura 64. Mapeamento em linha da distribuição dos elementos químicos presentes na superfície da amostra-1. 
Nas Figuras 65 a 68 estão mostrados os resultados da distribuição de elementos químicos em pontos e em varredura por linha ("line scan") e imagem da respectiva região analisada da amostra na condição 2. O mapeamento gerado mostra a distribuição de elementos na linha que cruza regiões de incidência do feixe laser e zona afetada pelo calor.
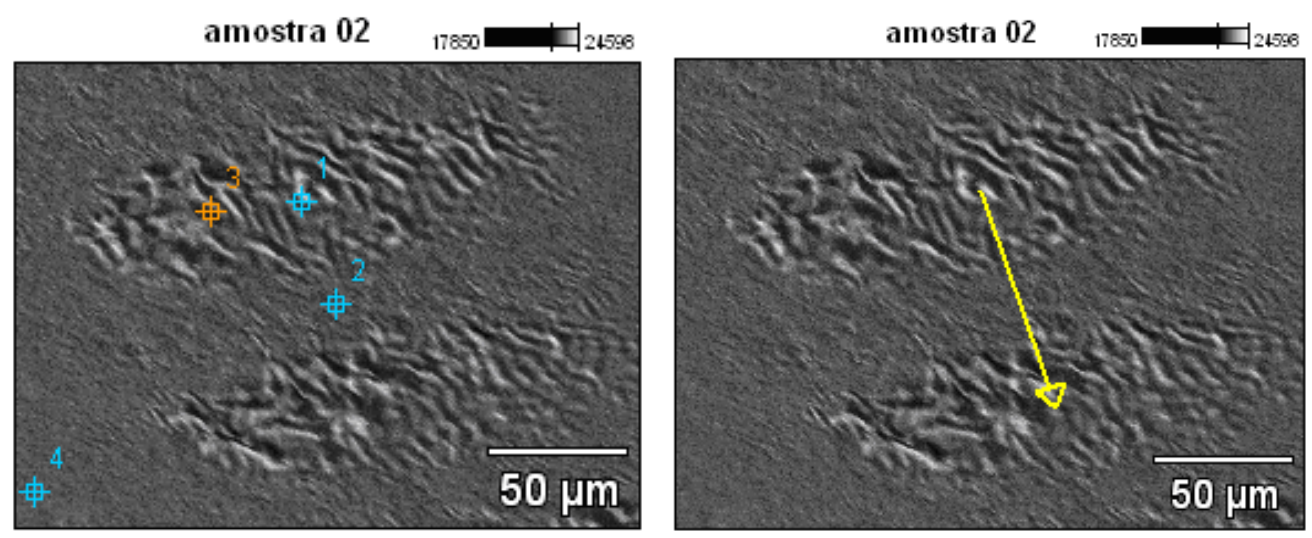

Figura 65. Regiões da amostra-2 analisadas por pontos e por linha, respectivamente. A seta indica o sentido adotado para a análise por "line scan". Aumento: 500x. Sem ataque.

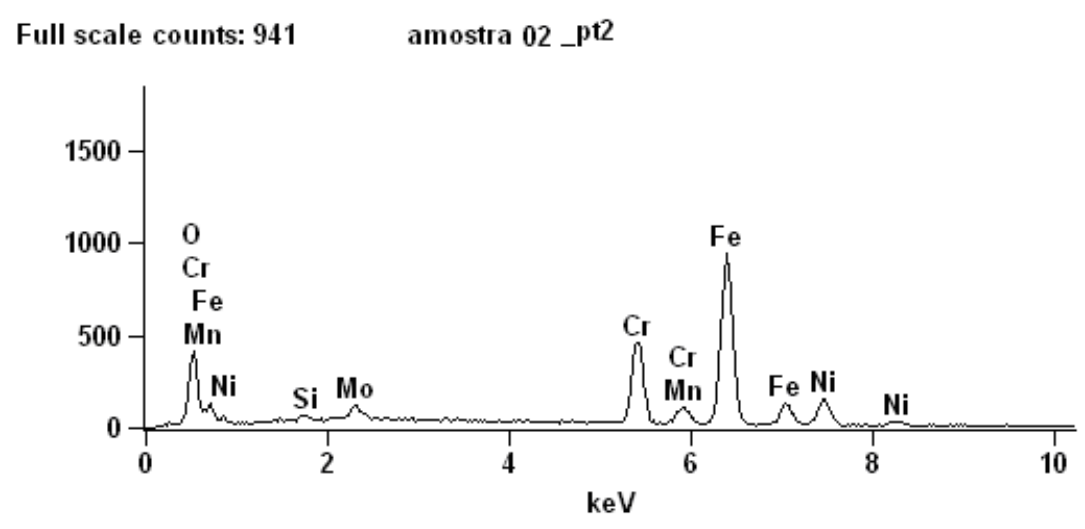

Figura 66. Espectro de EDS para o ponto-2, região termicamente afetada pelo laser.

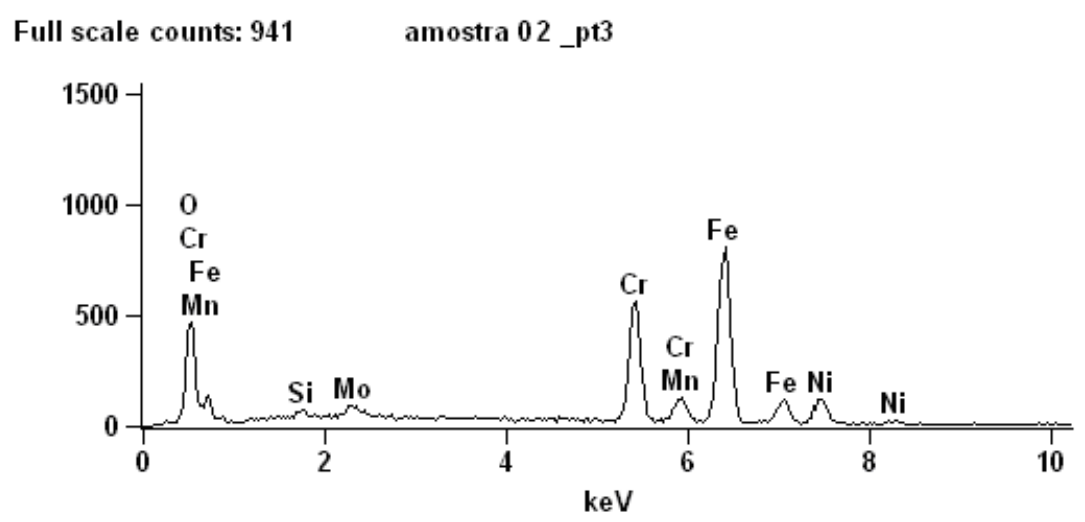

Figura 67. Espectro de EDS para o ponto-3, região de marcação a laser. 


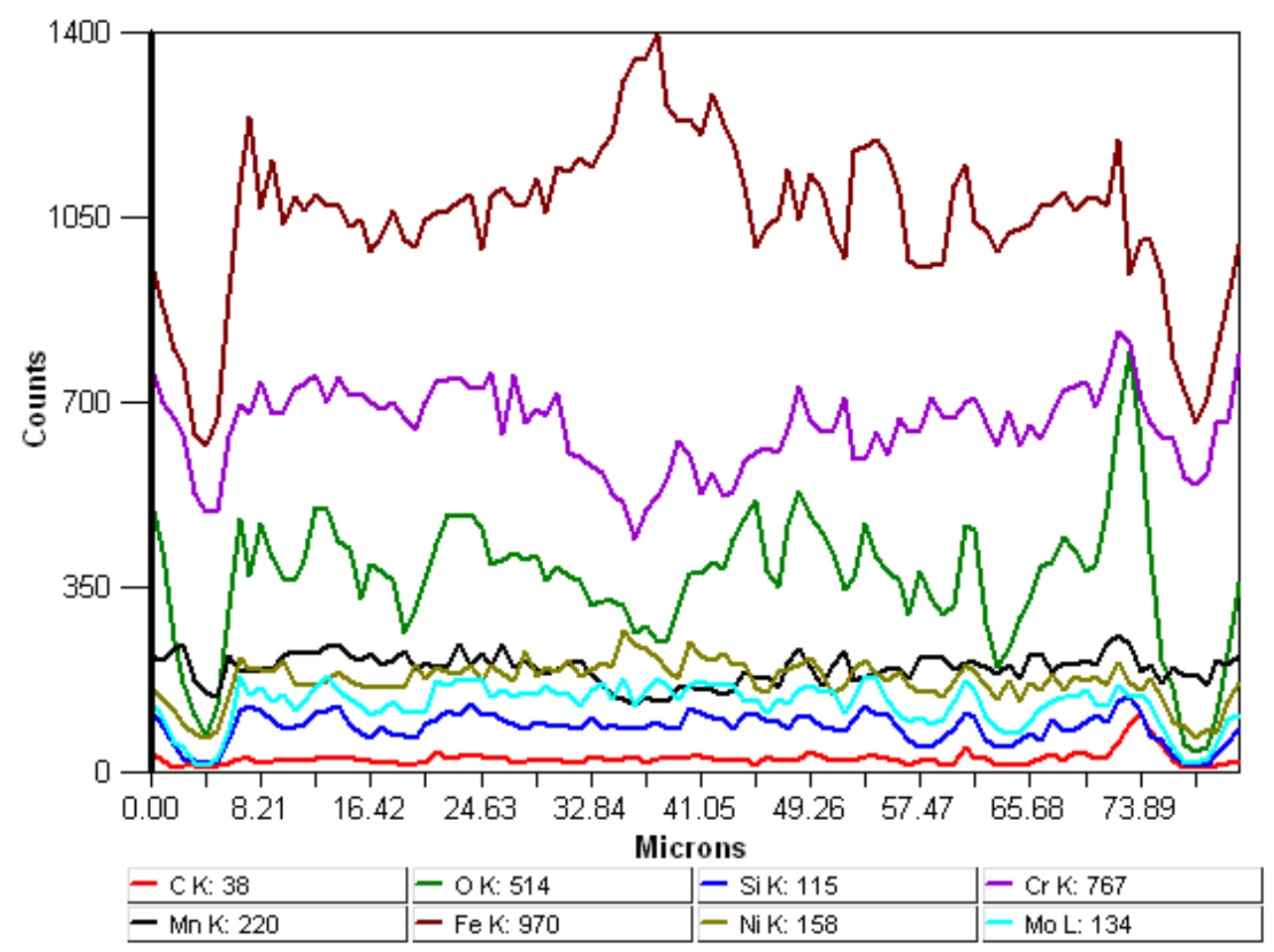

Figura 68. Mapeamento em linha da distribuição dos elementos químicos presentes na superfície da amostra-2.

Na Figura 68, para a amostra na condição 2, o mapeamento por line scan mostra uma tendência do espectro do elemento oxigênio acompanhar o do elemento cromo, principalmente na posição $40 \mu \mathrm{m}$, onde ocorre diminuição de cromo, o teor de oxigênio também diminuiu.

Nas Figuras 69 a 72 estão apresentados os resultados da distribuição de elementos químicos em pontos e em varredura por linha ("line scan") e imagem da respectiva região analisada para a amostra tratada por feixe laser de fibra óptica na condição 3.

O mapeamento gerado mostra a distribuição de elementos na linha que cruza regiões de incidência do feixe laser e zona afetada pelo calor. 

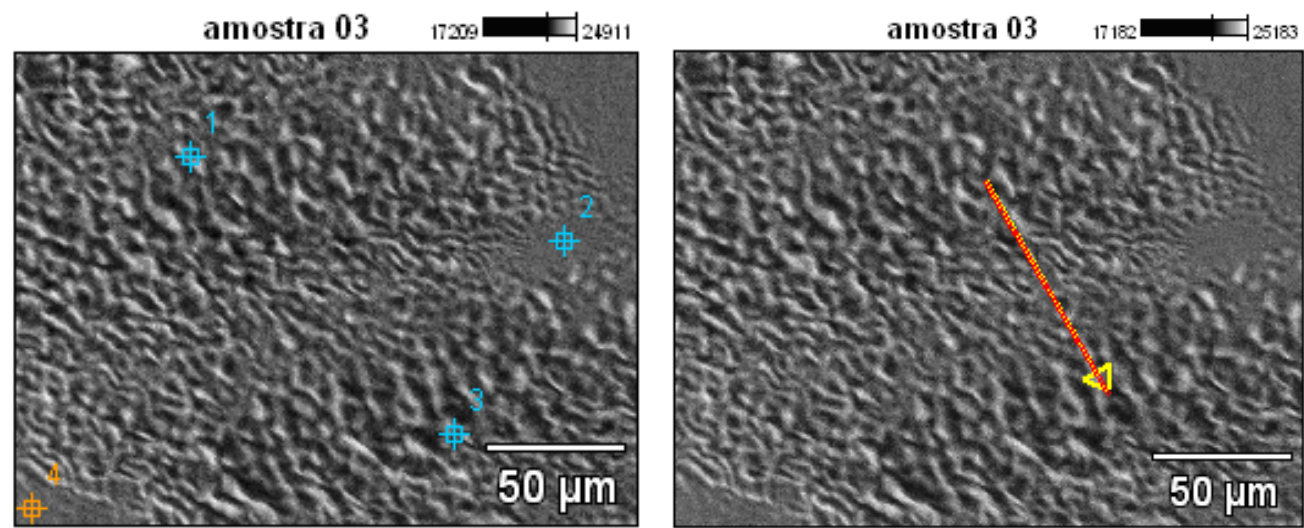

Figura 69. Regiões da amostra-3 analisadas por pontos e por linha, respectivamente. A seta indica o sentido adotado para a análise por "line scan". Aumento: 500x. Sem ataque.

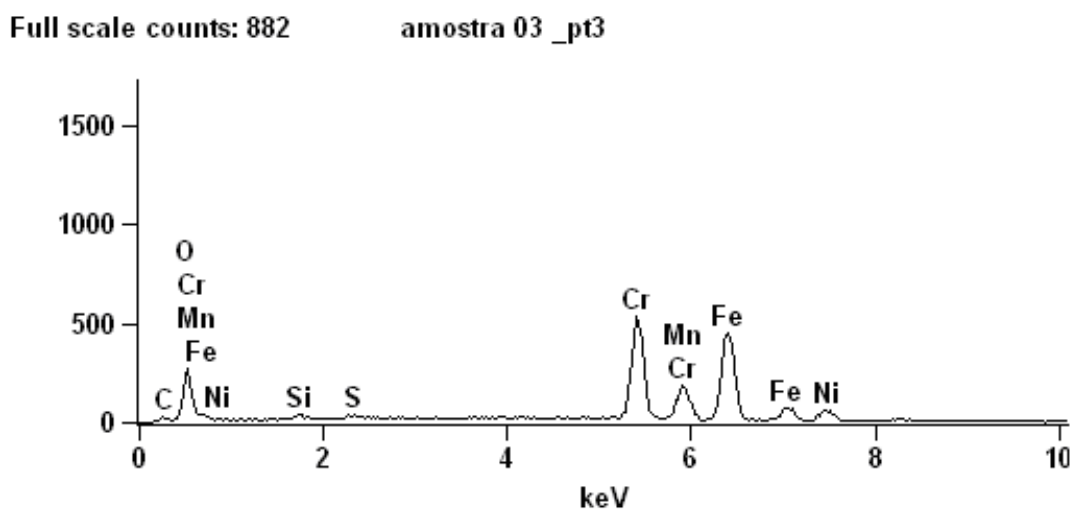

Figura 70. Espectro de EDS para o ponto-3, região marcada pelo laser.

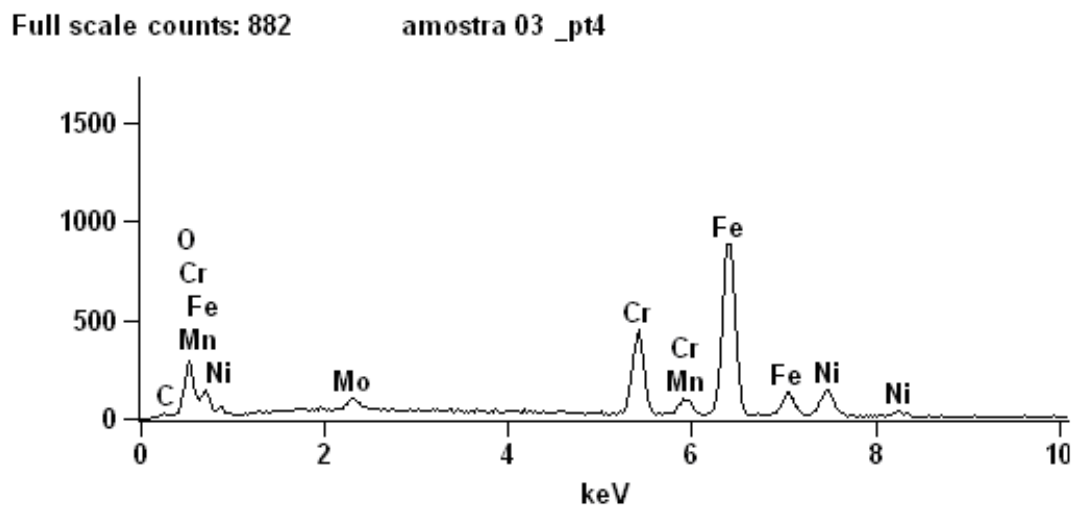

Figura 71. Espectro de EDS para o ponto-4, região sem marcação a laser.

A análise dos espectros obtidos nos pontos selecionados indica um ligeiro aumento na concentração de cromo e diminuição de ferro (ponto 3) na região de incidência do feixe laser; o que não foi observado para o ponto 4, que corresponde à região sem marcação a laser. Na análise da distribuição por "line scan" nota-se ligeira diminuição na contagem de ferro e aumento nas contagens de cromo e manganês. 


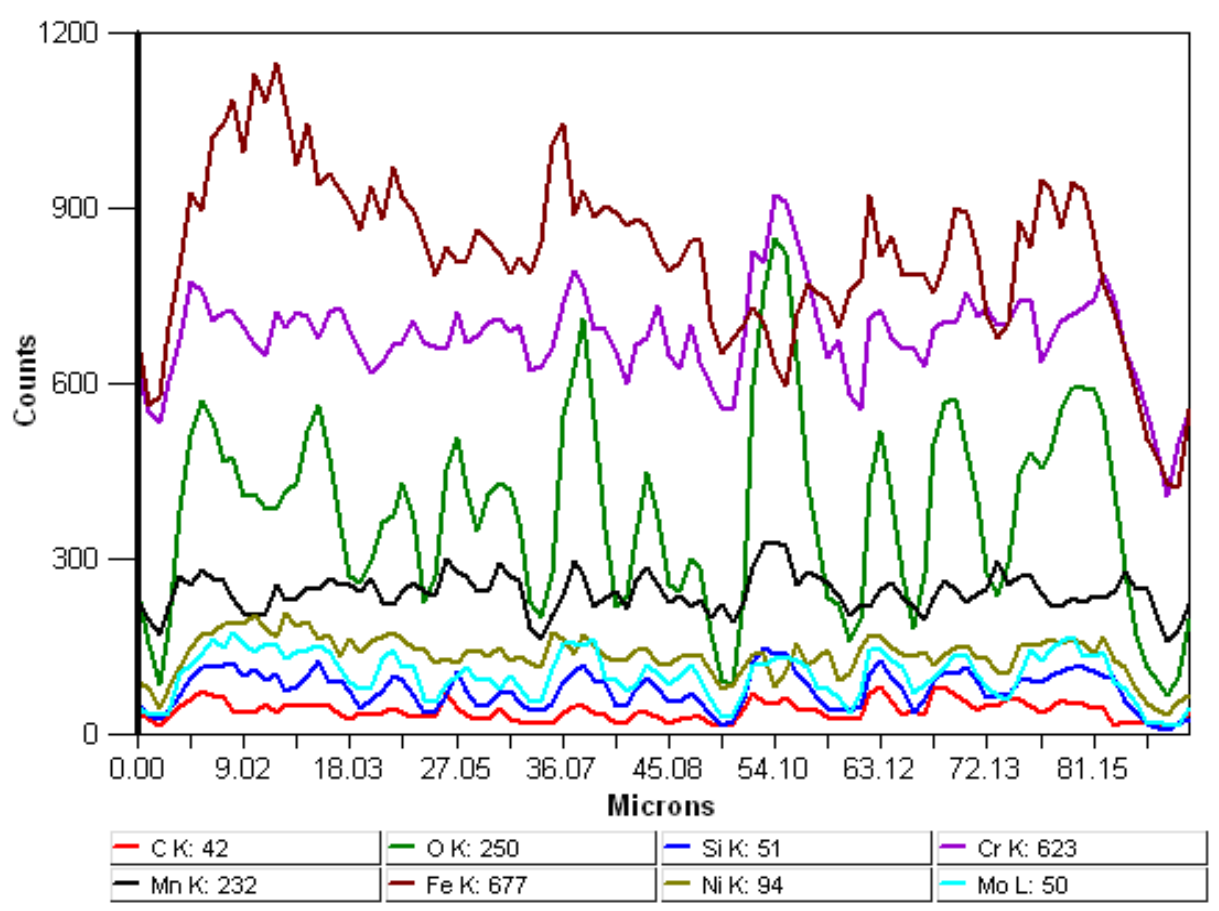

Figura 72. Mapeamento em linha da distribuição dos elementos químicos presentes na superfície da amostra-3.

Nas Figuras 73 a 76 são apresentados os resultados da distribuição de elementos químicos em pontos e em varredura por linha ("line scan"), e imagem da respectiva região analisada para a amostra tratada por feixe laser com os parâmetros da condição 4. No mapeamento gerado é mostrada a distribuição de elementos na linha que cruza regiões de incidência do feixe laser e zona afetada pelo calor, na amostra com marcações.

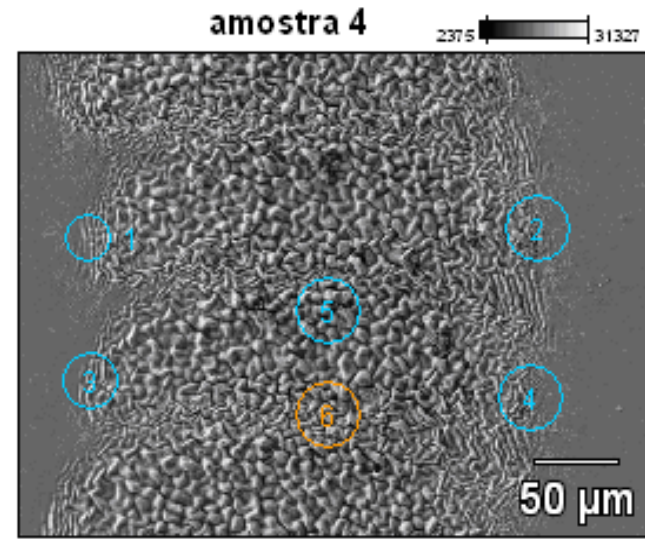

(a)

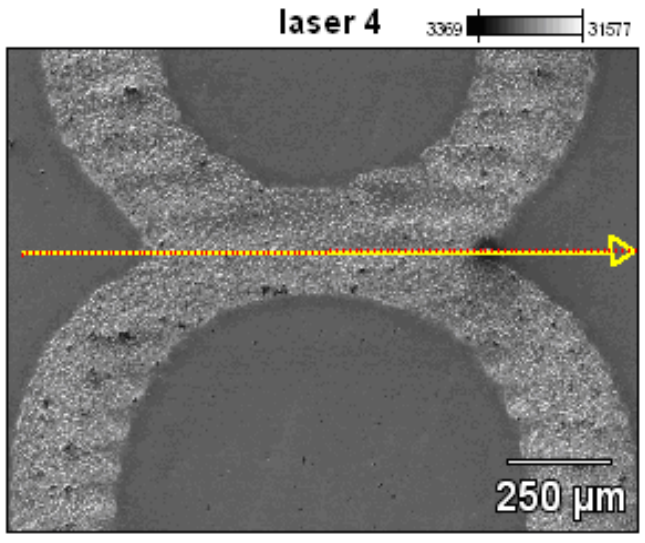

(b)

Figura 73. Regiões da amostra-4 analisadas por pontos e por linha, respectivamente. A seta indica o sentido adotado para a análise por "line scan". Aumentos: (a) 500x e (b) 75x, respectivamente. Sem ataque. 


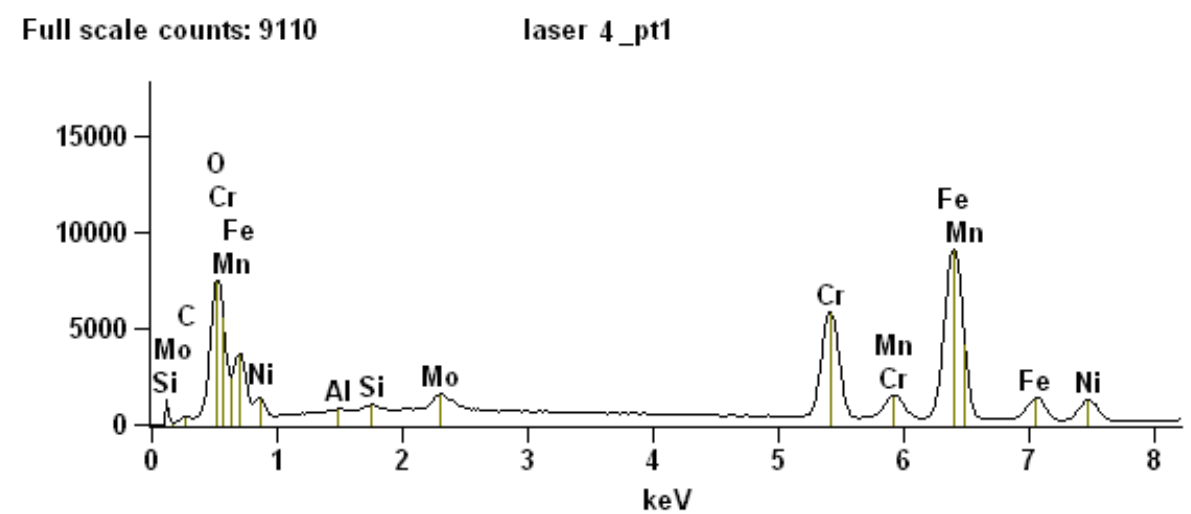

Figura 74. Espectro de EDS para o ponto-1, região termicamente afetada pelo feixe laser.

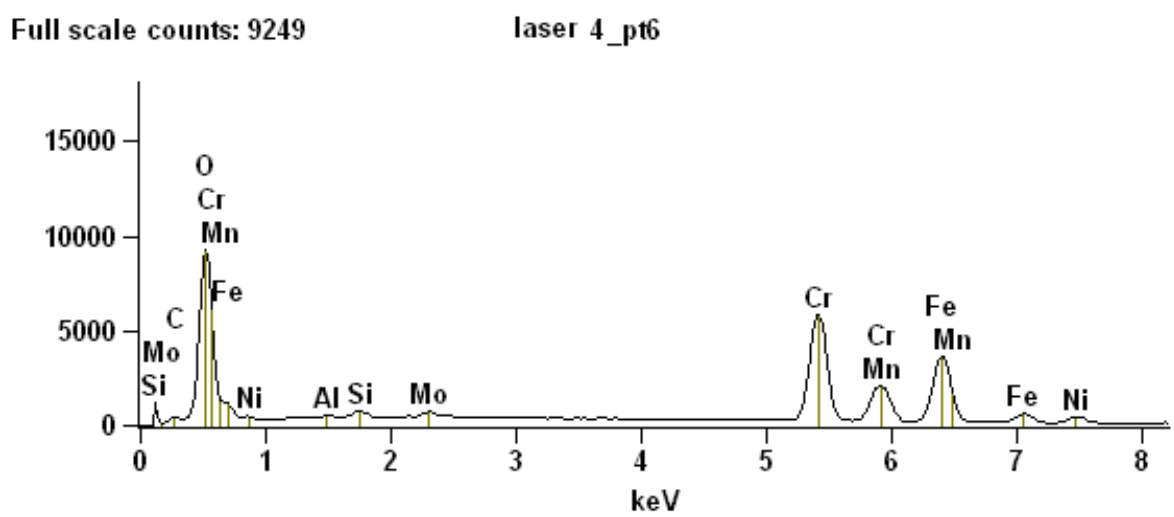

Figura 75. Espectro de EDS para o ponto-6, região de incidência do feixe laser.

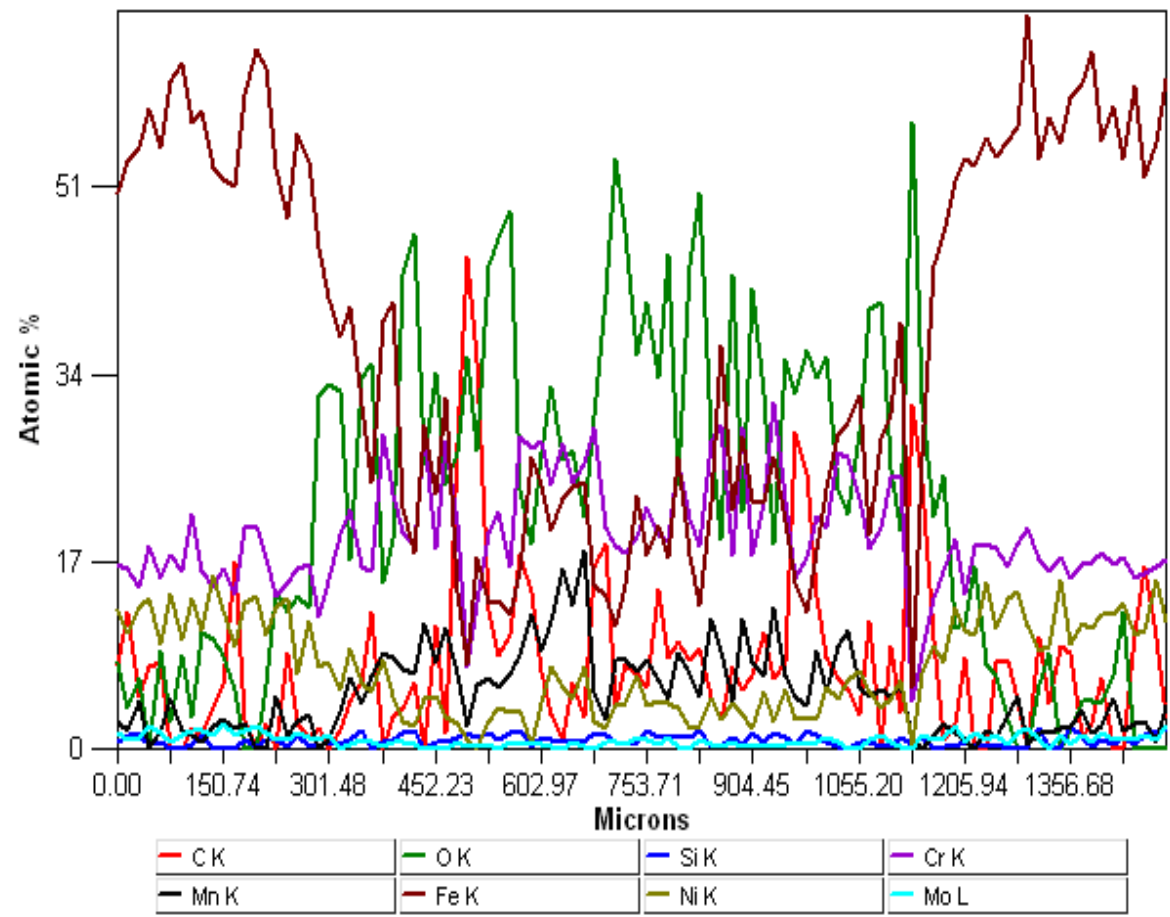

Figura 76. Mapeamento em linha da distribuição dos elementos químicos presentes na superfície da amostra-4. 
Como observado pelos espectros e distribuição por "line scan" apresentados, a amostra 4 tratada por feixe laser com os parâmetros informados anteriormente, foi a que apresentou maior variação da composição química dos elementos presentes neste biomaterial. Portanto, a amostra 4 foi avaliada mais detalhadamente e os resultados obtidos estão apresentados a seguir nas Figuras 77 a 86. Notou-se um aumento dos teores do elemento cromo e uma diminuição dos teores do elemento ferro, como encontrado nas outras amostras, marcadas nas condições citadas. Na região de incidência do feixe laser, na amostra-4, houve um aumento nos teores de manganês e oxigênio.

O aumento de oxigênio pode ser explicado pelo fato das marcações e texturizações terem sido realizadas ao ar, isto é, sem atmosfera de proteção. Notou-se também uma queda nos teores de níquel e de molibdênio.

As imagens seguintes são exemplos deste comportamento que foi observado nas regiões onde ocorreu a fusão deste aço inoxidável austenítico e nas regiões de transição, ou seja, regiões de picos e vales e da zona termicamente afetada que corresponderam aos sítios com as maiores quantidades de pites de corrosão, obtidos após os ensaios de polarização cíclica, como já fora apresentado e discutido.

Foram avaliadas regiões com diferentes ampliações a fim de se verificar mudanças significativas nas concentrações dos elementos químicos em função das microestruturas formadas pelo feixe laser nos parâmetros utilizados. Algumas regiões apresentaram diminuição de concentrações de ferro e oxigênio e aumento de manganês e cromo.

Os resultados exibidos indicam a causa da diminuição da resistência, das amostras tratadas a laser, frente à corrosão por pite. Entre as regiões de picos e vales, mais claras e mais escuras, respectivamente, formados pela fusão gerada pelo feixe laser e a matriz há regiões de frestas de dimensões micrométricas ou nanométricas, onde por razões de aeração diferencial inicia-se o mecanismo de corrosão que produziu os pites uma vez que, o processo de corrosão inicia-se na nestas interfaces. 


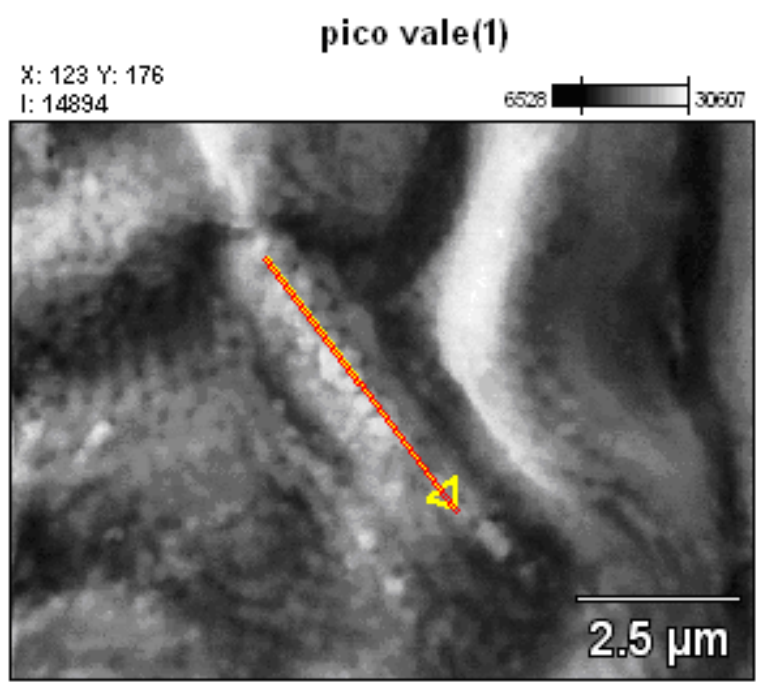

Figura 77. Região de transição pico-vale (1) da amostra-4 analisada por linha. A seta indica o sentido adotado para a análise por "line scan". Aumento: 10.000x. Sem ataque.

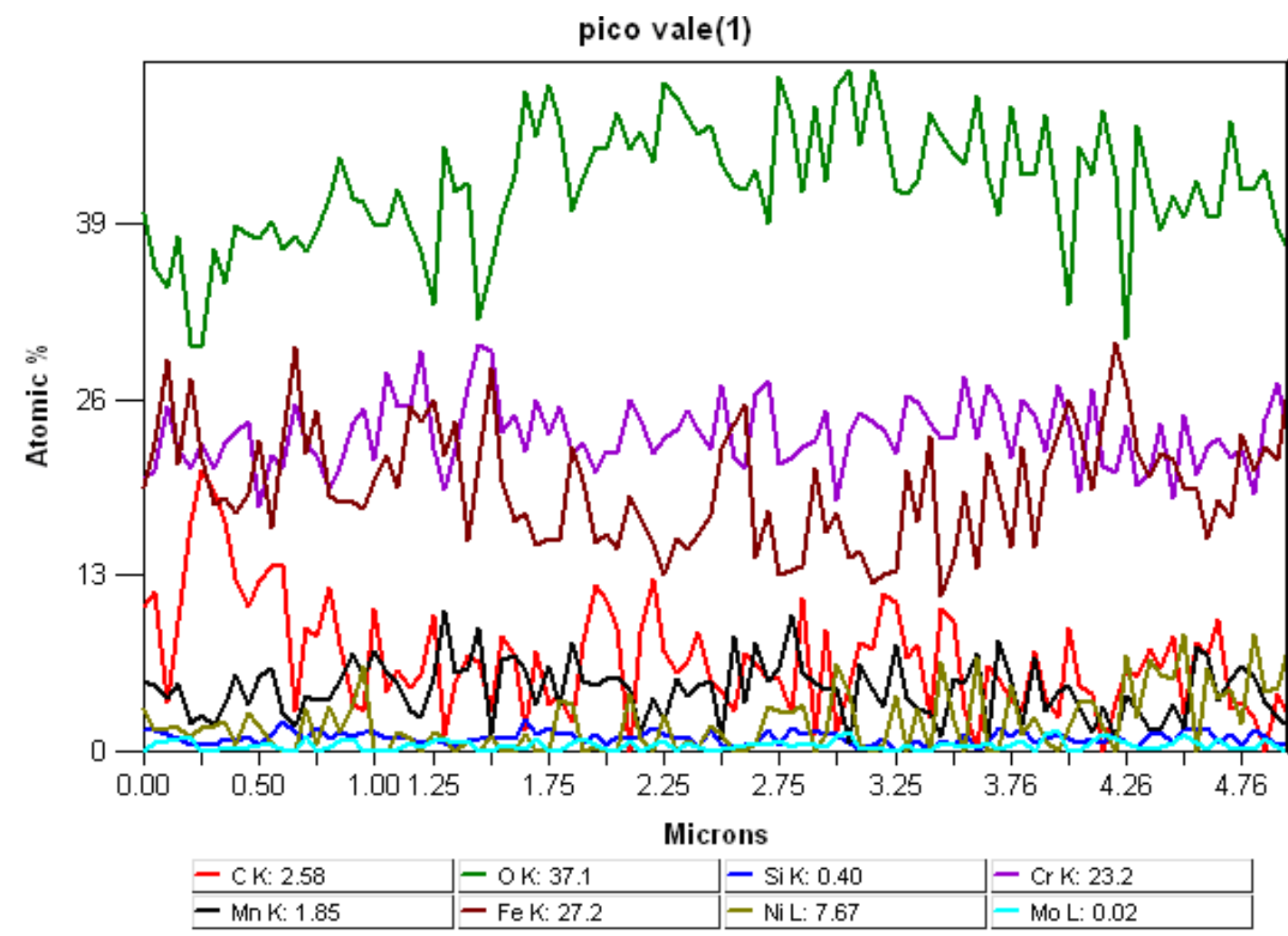

Figura 78. Mapeamento em linha da distribuição dos elementos químicos presentes na superfície da amostra-4, região pico-vale (1).

A avaliação qualitativa da região de transição pico-vale 1 da amostra 4 mostra grande aumento do teor de oxigênio, seguido dos elementos cromo e ferro; indicando que o feixe laser conduziu à formação de regiões de óxidos preferencialmente destes elementos. 


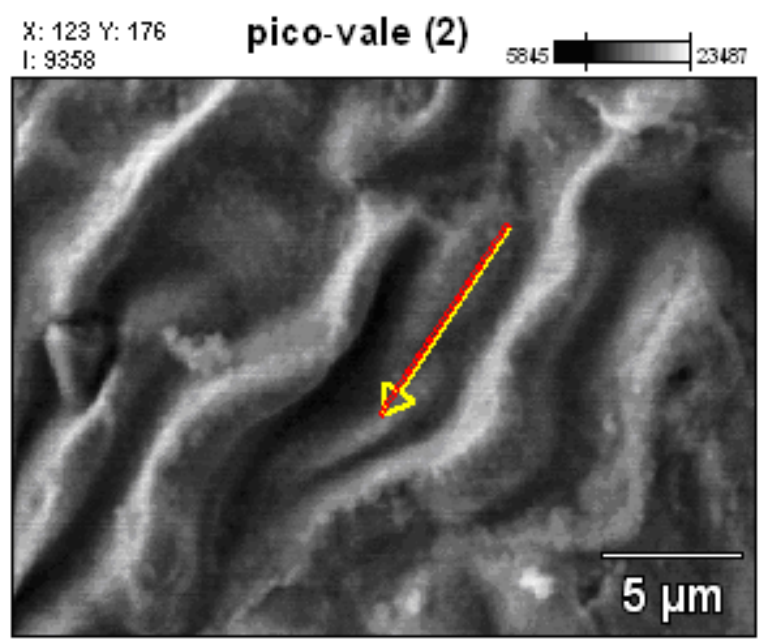

Figura 79. Região de transição pico-vale (2) da amostra-4 analisada por linha. A seta indica o sentido adotado para a análise por "line scan". Aumento: 4.300x. Sem ataque.

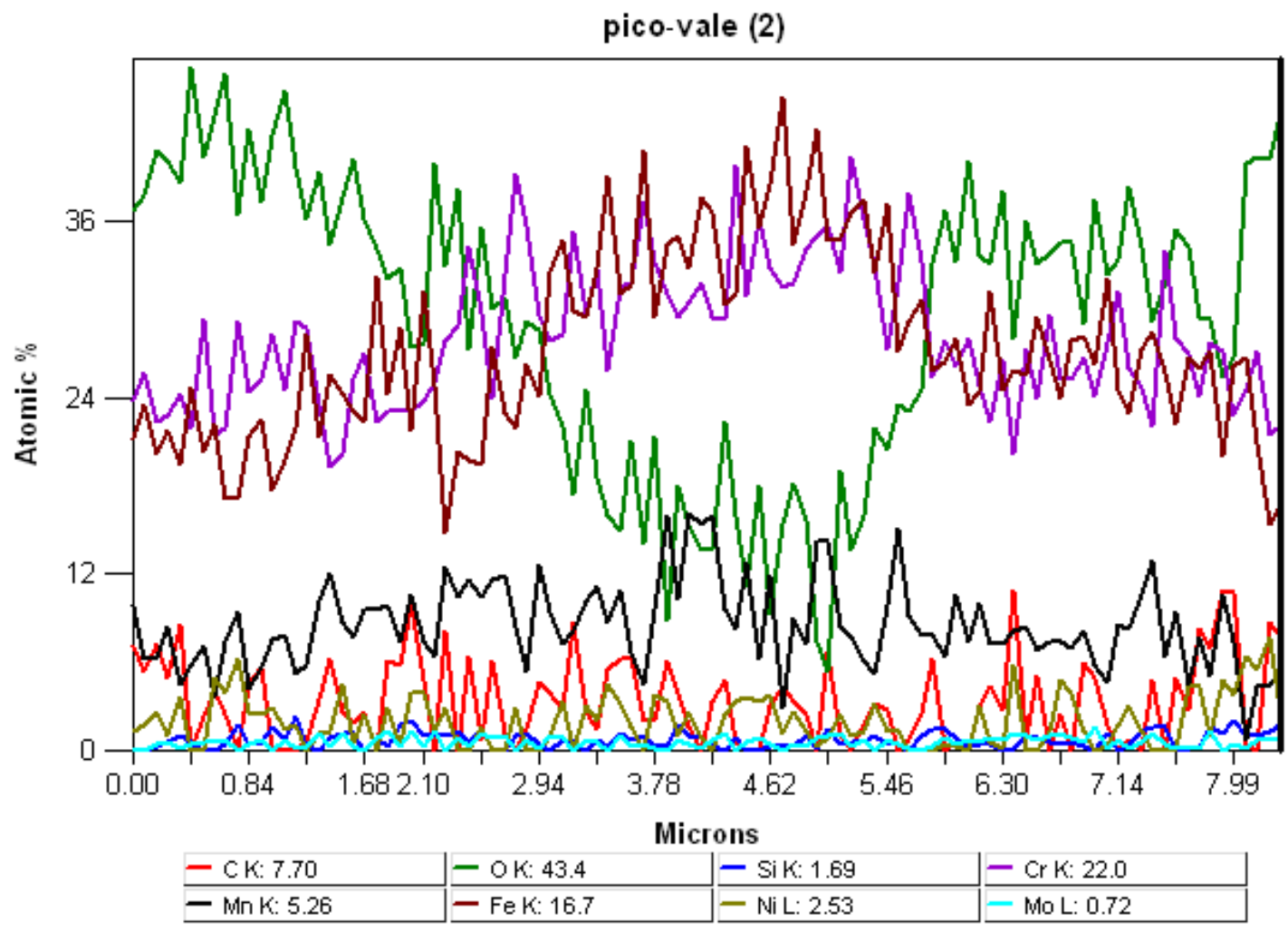

Figura 80. Mapeamento em linha da distribuição dos elementos químicos presentes na superfície da amostra-4, região pico-vale (2).

Avaliando-se o mapeamento em linha da região de transição pico-vale 2 da amostra 4, percebe-se que ocorreu diminuição na porcentagem atômica de oxigênio no local onde foram encontradas as maiores concentrações de ferro e cromo e manganês. 


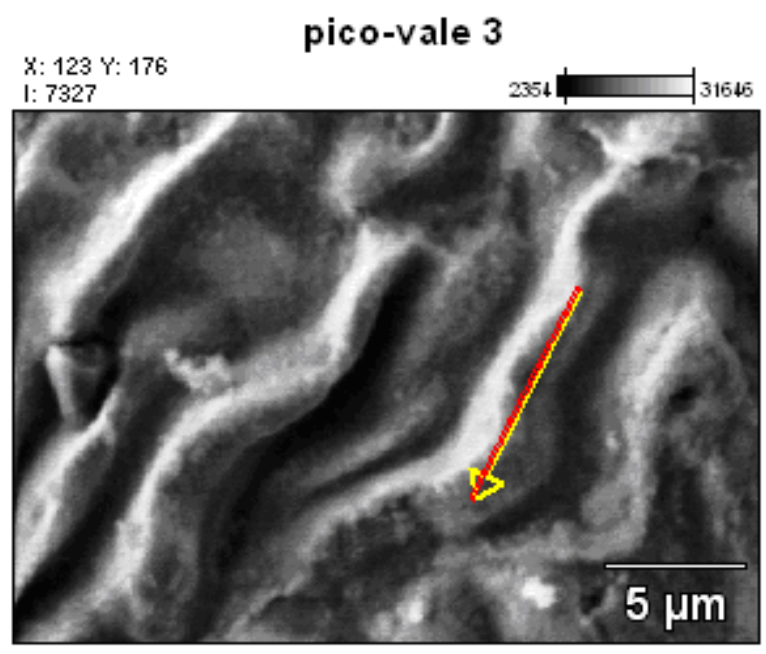

Figura 81. Região de transição pico-vale (3) da amostra-4 analisada por linha. A seta indica o sentido adotado para a análise por "line scan". Aumento: 4.300x. Sem ataque.

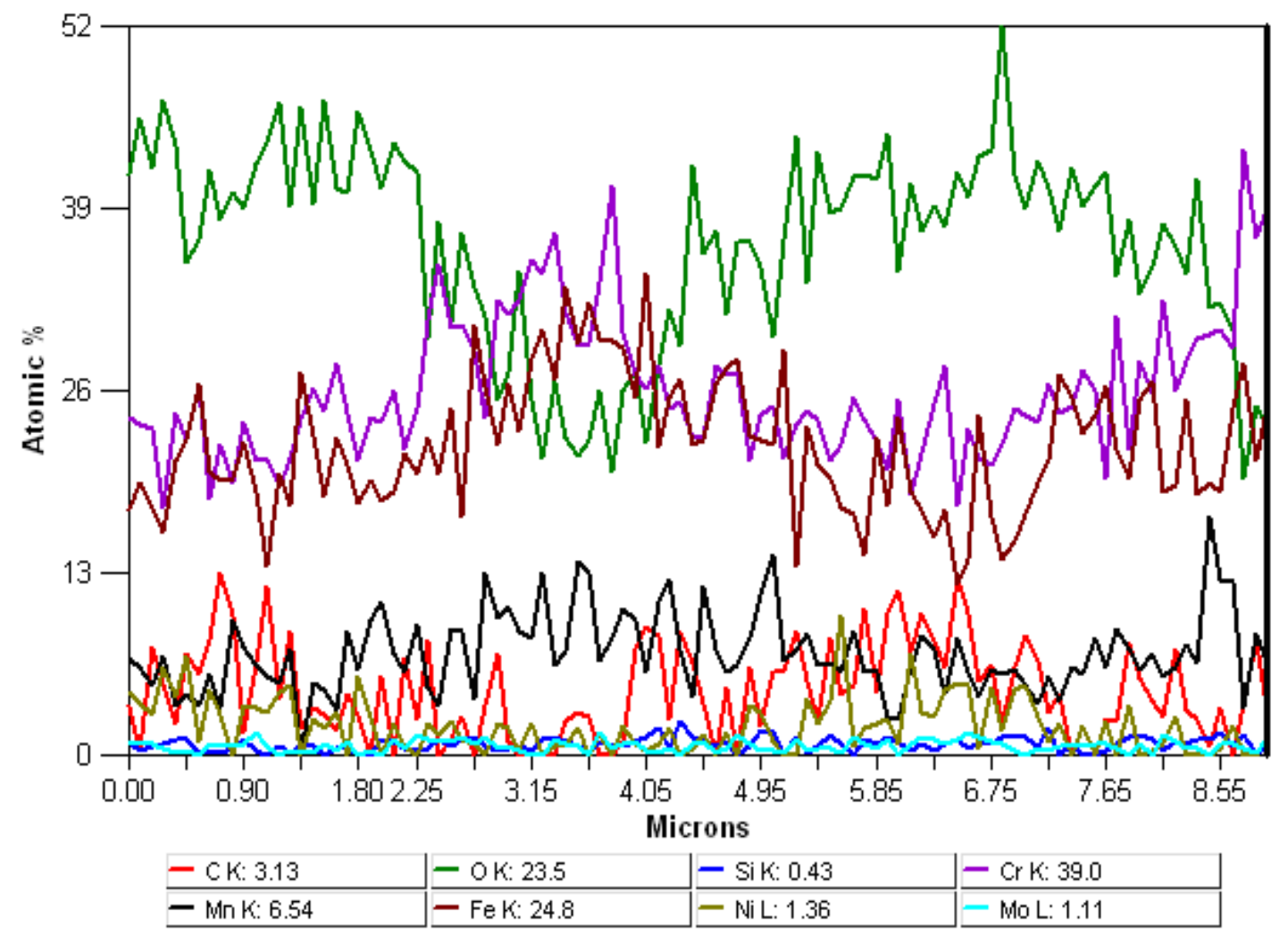

Figura 82. Mapeamento em linha da distribuição dos elementos químicos presentes na superfície da amostra-4, região pico-vale (3).

A avaliação qualitativa da região de transição pico-vale 3 da amostra 4 mostrou aumento do teor de oxigênio nos locais em que foram obtidos os menores teores de ferro, cromo e manganês; ademais, para a região analisada, onde houve decréscimo do teor de oxigênio foram encontradas as maiores concentrações de cromo e ferro. 


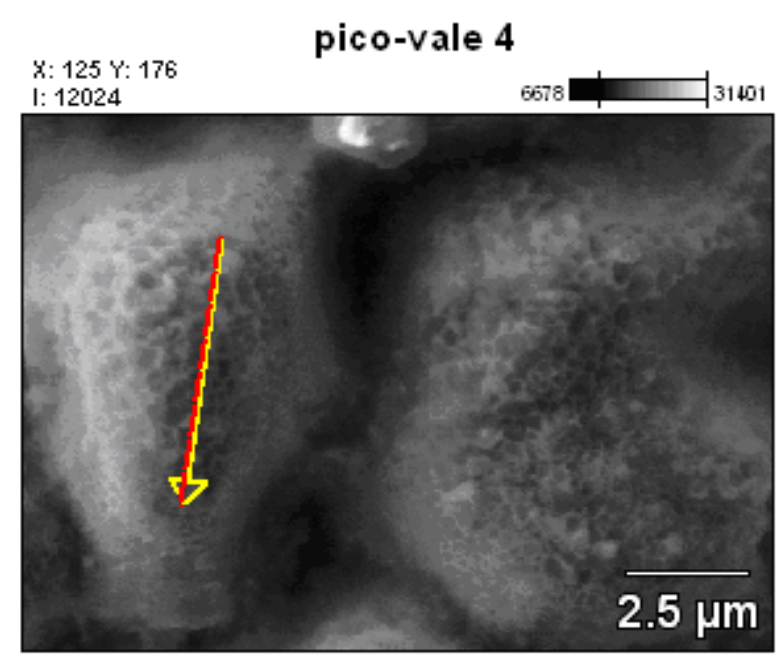

Figura 83. Região de transição pico-vale (4) da amostra-4 analisada por linha. A seta indica o sentido adotado para a análise por "line scan". Aumento: 7.500x. Sem ataque.

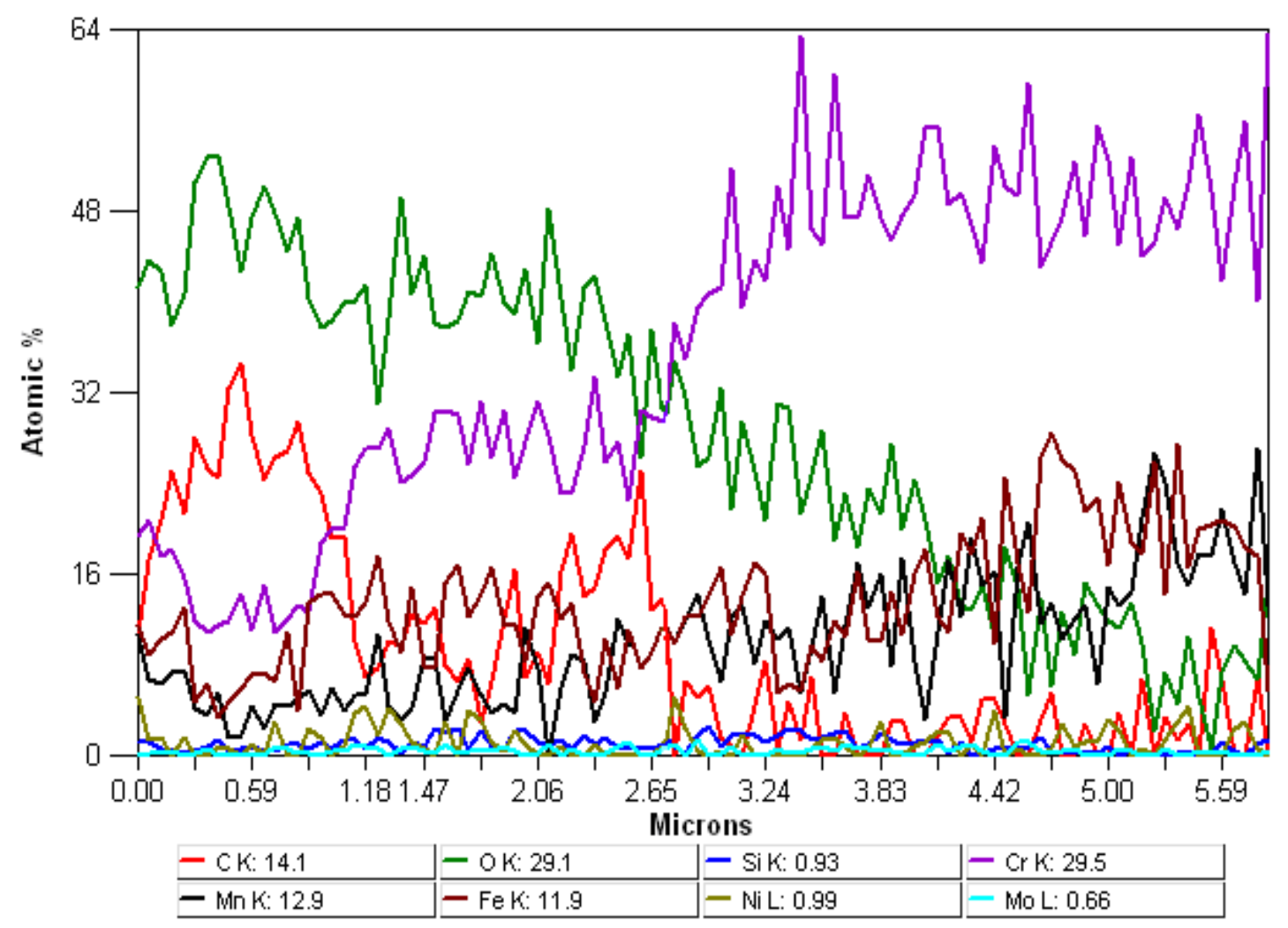

Figura 84. Mapeamento em linha da distribuição dos elementos químicos presentes na superfície da amostra-4, região pico-vale (4).

O mapeamento da região pico-vale 4, da amostra tratada na condição 4, indica que na região investigada houve uma queda contínua do teor de oxigênio, enquanto foi detectado aumento do teor de cromo, ferro e manganês, picos de carbono também foram observados nesta região selecionada. 


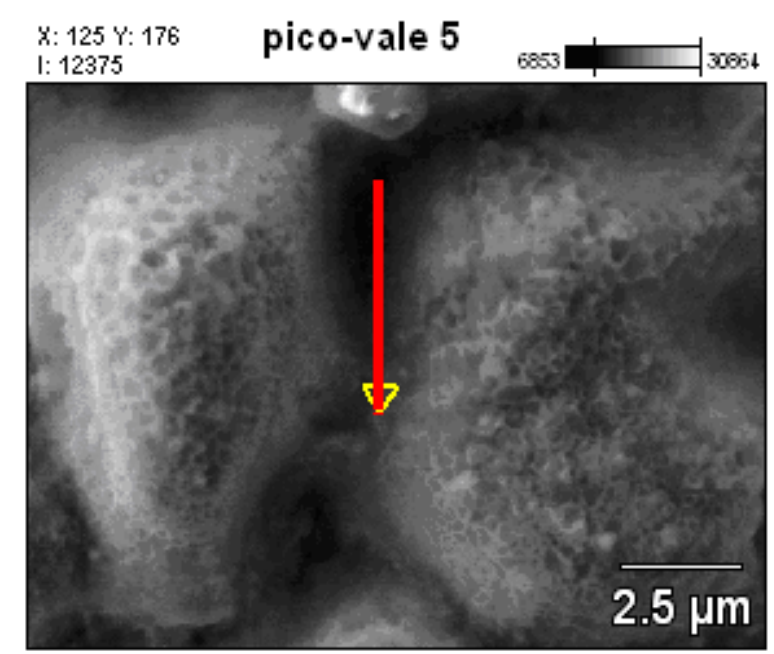

Figura 85. Região de transição pico-vale (5) da amostra-4 analisada por linha. A seta indica o sentido adotado para a análise por "line scan". Aumento: 7.500x. Sem ataque.

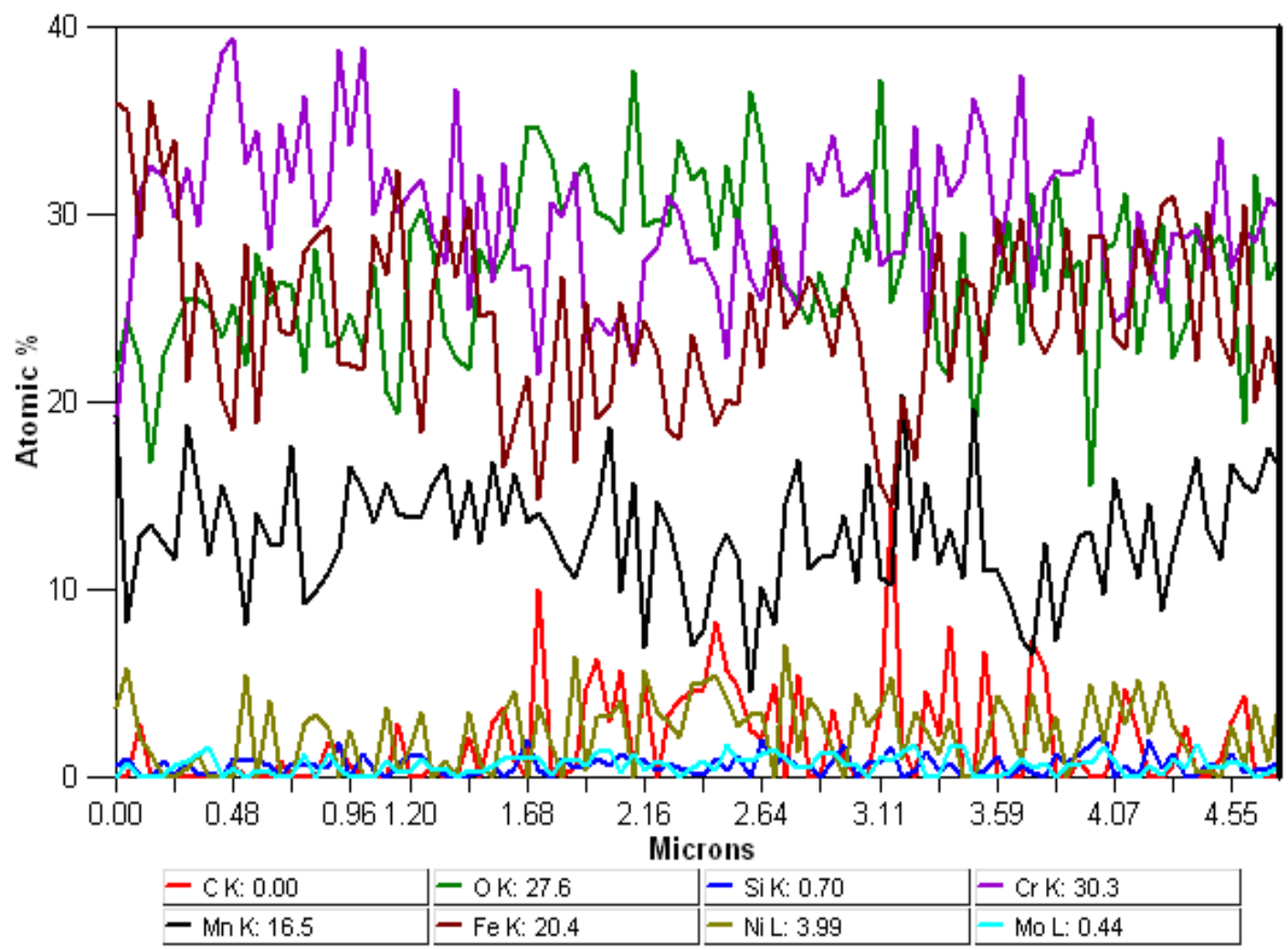

Figura 86. Mapeamento em linha da distribuição dos elementos químicos presentes na superfície da amostra-4, região pico-vale (5).

Na Figura 87 é apresentada uma imagem com aumento de 300 vezes da região com marcação a laser da amostra 4, onde foram selecionados 6 pontos para análise por EDS e os resultados obtidos estão apresentados na Tabela 16. 


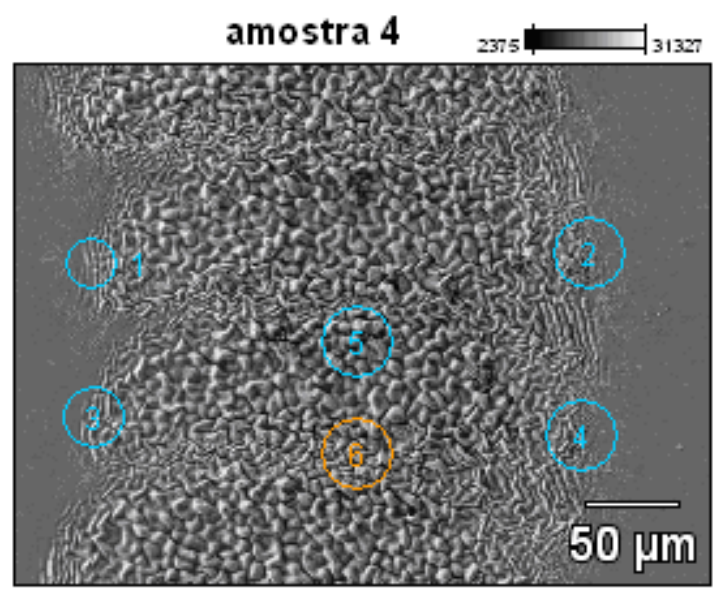

Figura 87. Regiões da amostra na condição 4 analisadas por pontos. Aumento: 300x.

Tabela 16. Composição química (\% em massa) obtida por EDS dos elementos encontrados nos pontos selecionados na imagem da Figura 66.

\begin{tabular}{c|c|c|c|c|c|c|c|c|c}
\hline Elemento / Ponto & $\mathrm{C}$ & $\mathrm{O}$ & $\mathrm{Al}$ & $\mathrm{Si}$ & $\mathrm{Cr}$ & $\mathrm{Mn}$ & $\mathrm{Fe}$ & $\mathrm{Ni}$ & $\mathrm{Mo}$ \\
\hline 1 & 0,2 & 7,4 & 0,2 & 0,4 & 19,7 & 3,1 & 55,0 & 11,8 & 2,1 \\
\hline 2 & 1,4 & 8,3 & 0,6 & 0,5 & 20,2 & 3,6 & 51,5 & 11,4 & 2,3 \\
\hline 3 & 0,7 & 8,2 & 0,2 & 0,4 & 21,1 & 3,5 & 53,2 & 10,7 & 2,0 \\
\hline 4 & 1,6 & 8,3 & 0,4 & 0,5 & 20,1 & 3,5 & 51,9 & 11,4 & 2,1 \\
\hline 5 & 5,9 & 13,1 & 2,5 & 0,7 & 30,5 & 10,6 & 30,4 & 5,2 & 1,0 \\
\hline 6 & 2,1 & 13,4 & 0,1 & 0,6 & 32,2 & 11,5 & 33,1 & 5,8 & 1,1 \\
\hline
\end{tabular}

Como é notado nas figuras apresentadas correlacionando-as com a Tabela 16 de composição química, os elementos: cromo, manganês, ferro e níquel foram os que apresentaram as maiores variações em composição química, o que sugere que o tratamento via feixe laser gerou zonas empobrecidas e zonas enriquecidas destes elementos em comparação com a matriz. Nota-se a maior afinidade dos elementos majoritários pelo oxigênio.

Os resultados obtidos com esta técnica podem ser correlacionados com os obtidos por XPS. Vale ressaltar que o feixe de raios $X$ do detector de EDS penetra levemente para o interior da amostra, enquanto que na técnica de XPS foi analisado exclusivamente o óxido formado sobre as superfícies em uma extensão máxima de $10 \mathrm{~nm}$ de espessura, ou seja, a camada passiva do aço inoxidável, portanto existe certa discrepância. 
O mecanismo proposto para explicar este fenômeno se baseia na relação entre as densidades, pesos atômicos e pontos de fusão destes elementos químicos. Na Tabela 17 é ilustrada esta hipótese. Tanto a marcação quanto a texturização por feixe laser envolvem fase líquida, ou seja, fusão da superfície. A variação da concentração final dos elementos também é fortemente influenciada pela pressão de vapor dos componentes. A difusividade térmica para cada elemento depende da temperatura gerada pelo laser e da distância. Portanto, na solidificação os elementos menos densos acabam se alojando mais próximos da superfície, como é o caso do cromo, manganês e ferro, encontrados em maiores quantidades.

Tabela 17. Propriedades físicas dos elementos químicos majoritários do aço inoxidável austenítico ABNT NBR ISO 5832-1

\begin{tabular}{c|c|c|c}
\hline Elemento & Peso atômico & Densidade $\left[\mathrm{g} \cdot \mathrm{cm}^{-3}\right]$ & Ponto de fusão $\left[{ }^{\circ} \mathrm{C}\right]$ \\
\hline $\mathrm{Cr}$ & 52,00 & 7,19 & 1875 \\
\hline $\mathrm{Mn}$ & 54,94 & 7,44 & 1244 \\
\hline $\mathrm{Fe}$ & 55,85 & 7,87 & 1538 \\
\hline $\mathrm{Ni}$ & 58,69 & 8,90 & 1455 \\
\hline $\mathrm{Mo}$ & 95,94 & 10,22 & 2617 \\
\hline
\end{tabular}

Fonte: [20].

\subsection{Análises de Propriedades Biomecânicas do Biomaterial}

No campo da avaliação biomecânica é importante realizar estudos cinéticos, cinemáticos, eletromiográficos, antropométricos e de dinamometria para se conhecer as forças que atuarão em determinada articulação, alvo de estudo para caracterização do biomaterial que irá substituí-la, a fim de se estabelecer os níveis de tensões dos carregamentos aplicados nos ensaios de resistência à fadiga, à tração e ao desgaste.

A determinação dos limites de tolerância do tecido biológico se faz necessária na medida em que são aumentadas as solicitações mecânicas a que este tecido está submetido. É sabido que os danos musculares comprometem a 
biomecânica da locomoção [93]. Durante as atividades motoras, de caráter esportivo ou quotidiano, os danos ao tecido biológico podem atingir níveis de deformação de cunho permanente, ou seja, irreversíveis, havendo a necessidade de intervenção cirúrgica para substituição, em parte ou total, do tecido, órgão ou sistema locomotor danificado.

A literatura científica acerca desta temática não é muito vasta, sendo esta uma das razões de se superestimar o tempo de vida útil de um implante e de superdimensionar-se o mesmo [94, 95].

As publicações referentes aos ensaios biomecânicos de biomateriais utilizam as clássicas técnicas de avaliação de comportamento mecânico dos materiais e de mecânica da fratura elasto-plástica. Outras utilizam ensaios cadavéricos [96, 97], ou simulações computacionais, que não reproduzem completamente o ambiente corpóreo ou situações encontradas in vivo.

A fixação adequada dos biomateriais também é um fator que influencia a biomecânica do movimento humano, portanto deve ser continuamente estudada, a fim de se desenvolver métodos que garantam a sua eficácia [98].

No que concerne ao sistema locomotor, é sabido que grande parte das cirurgias para reparação de lesões originadas por desgaste elevado e incapacitante tem origens distintas, desde o envelhecimento e fadiga até problemas na pisada e uso inadequado de calçados tanto para atividades cotidianas como esportivas. Portanto, é necessário conhecer o quanto um determinado calçado implica na marcha humana normal e patológica, e vice versa. O mesmo deve ser investigado acerca de indivíduos que receberam implantes, ou seja, investigar as alterações que o calçado produz nas articulações (naturais ou artificiais).

\subsubsection{Ensaios de Fadiga}

Os ensaios de resistência à fadiga foram realizados em uma máquina Instron, Electroplus, alocada no Laboratório de Mecânica dos Sólidos e Impacto em Estruturas do Departamento de Engenharia Mecânica da Escola Politécnica da USP. O carregamento utilizado foi de $100 \mathrm{kN}$, em $30 \mathrm{~Hz}$ de frequência, com amplitude de tensões $2 \mathrm{kN}$ e tensão média de $7,5 \mathrm{kN}$, em regime tração-tração, 
ao ar e em temperatura ambiente de $25^{\circ} \mathrm{C}$. Os corpos-de-prova foram produzidos em tamanho sub-size de acordo com a Norma ASTM E8/E8M-11 [99] e submetidos aos tratamentos de marcação a laser com os parâmetros citados anteriormente.

Os ensaios foram interrompidos ao se atingir a quantidade de $10^{7}$ ciclos, que é a recomendada para avaliação de próteses e implantes, sem que houvesse a ruptura dos corpos-de-prova. De acordo com as Normas ASTM E466-15 [100], ASTM E467-08 (Reapproved 2014) [101] e ABNT NBR 15613-3/16 [102], os ensaios devem ser encerrados ao se atingir este número de ciclos e caso não haja ruptura (com separação completa do corpo-de-prova) deve-se decretar vida em fadiga infinita. As Figuras 88 e 89 mostram um corpo-de-prova durante o ensaio e o mesmo após o ensaio, sem ruptura e praticamente nenhum alongamento.

No que concerne ao efeito do tratamento a laser sobre as superfícies deste biomaterial, pode-se concluir que os tratamentos de marcação, nos parâmetros empregados não implicaram em aumento de concentração de tensões suficiente para induzir a nucleação de trincas nas regiões tratadas a laser ou próximas a elas a ponto de desencadearem o processo de fratura por fadiga.

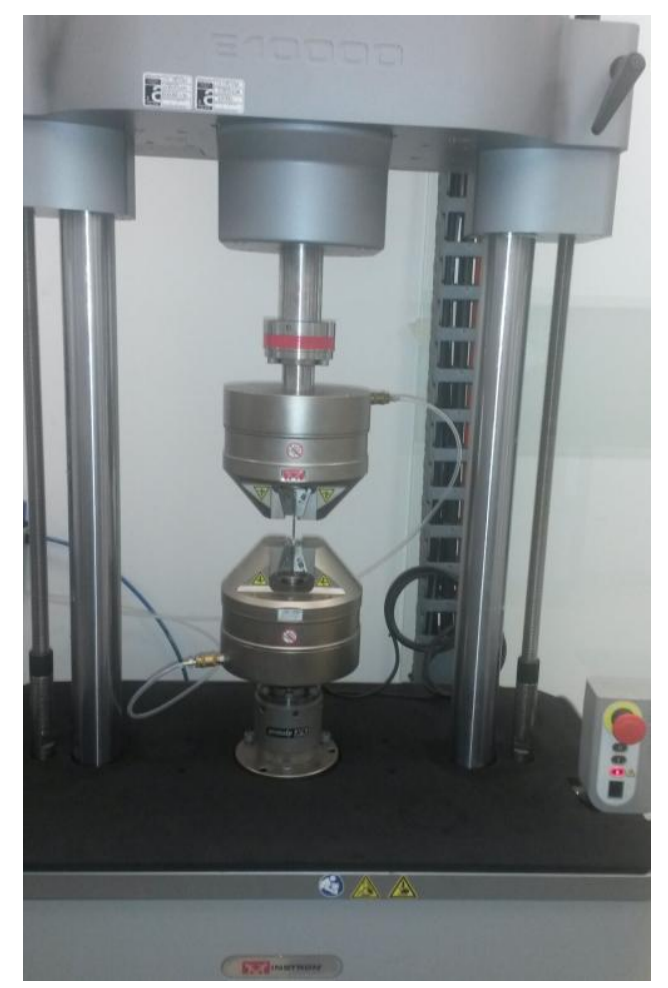

Figura 88. Corpo-de-prova marcado a laser durante ensaio de fadiga. 

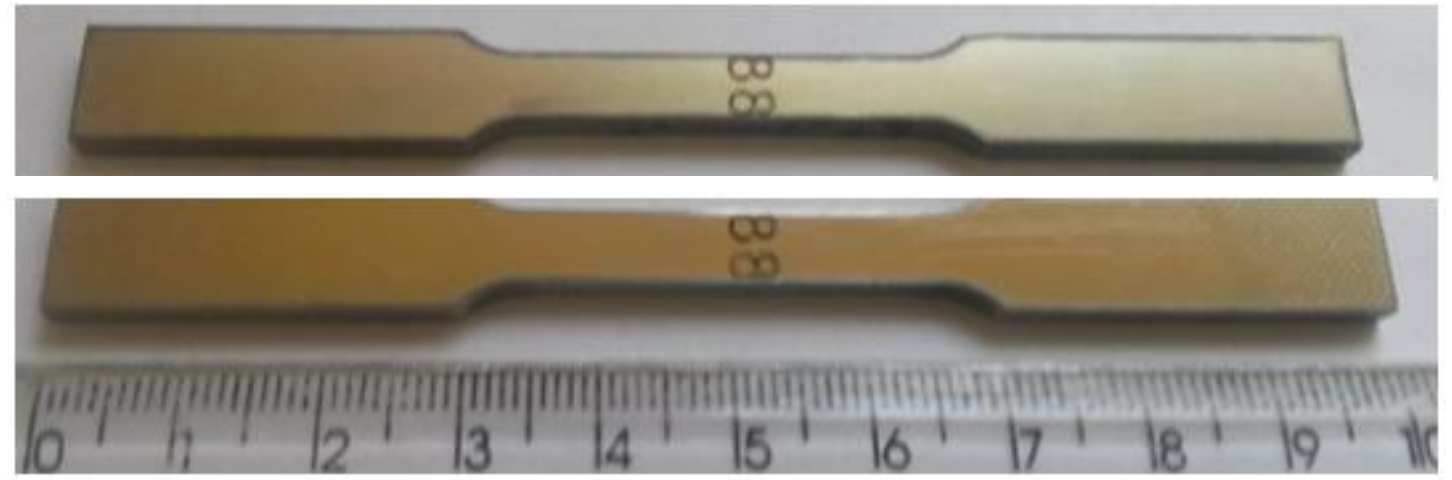

Figura 89. Imagens do corpo-de-prova marcado a laser antes do ensaio de fadiga (acima) e após o ensaio (abaixo).

O resultado obtido é muito desejável para os biomateriais usados em implantes ortopédicos. Outras características e propriedades específicas, tais como: composição química, tamanho de grão, tratamento térmico e até geometria dos corpos-de-prova possuem efeito preponderante sobre o comportamento frente à fadiga, do que os tratamentos superficiais utilizados nestas condições.

\subsubsection{Ensaios de Tração}

Amostras do referido biomaterial com os tratamentos citados foram submetidas a ensaio de tração padronizado. Os resultados obtidos estão apresentados na Figura 90, Força $[\mathrm{N}]$ versus Deformação [mm] e, Figura 91, Tensão $[\mathrm{MPa}]$ versus Deformação $[\mathrm{mm} / \mathrm{mm}$ ] e representam um montante de 6 amostras para cada tipo de acabamento superficial. 


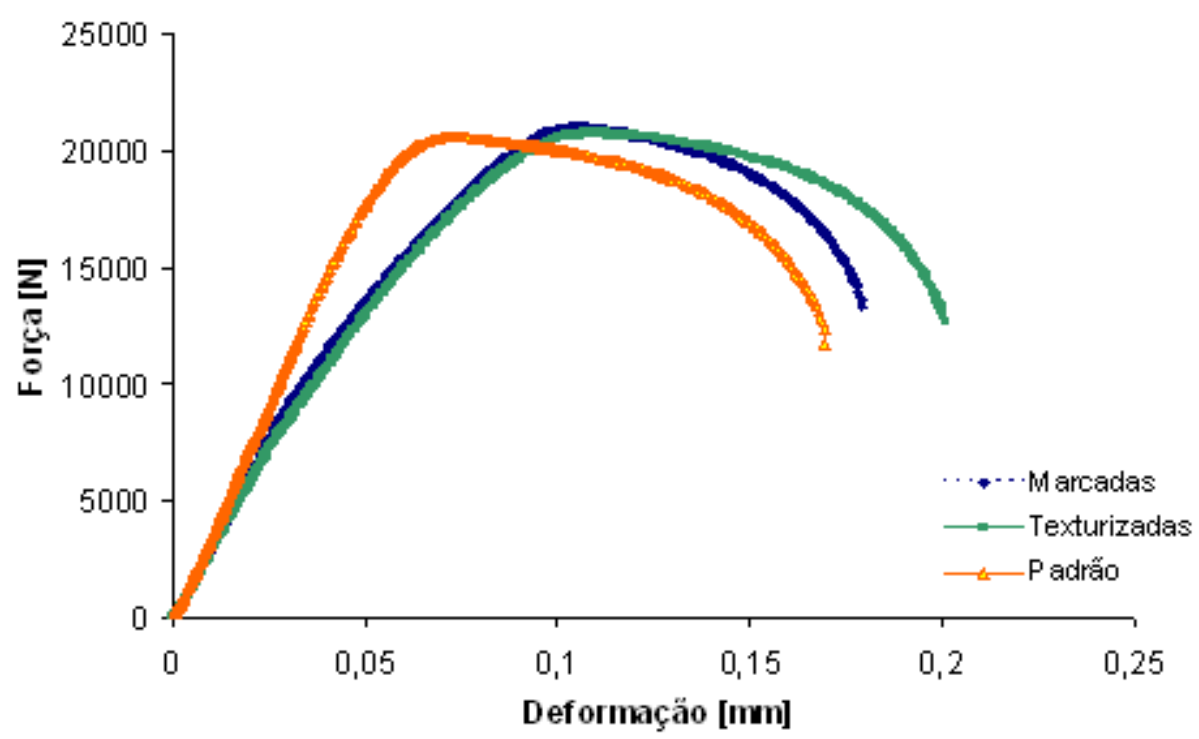

Figura 90. Gráfico da Força [N] versus Deformação [mm] para as três condições de acabamento superficial analisadas.

Independentemente do tipo de acabamento superficial empregado, as amostras suportaram força máxima da ordem de $20500 \mathrm{~N}$ e, na ruptura forças da ordem de $11000 \mathrm{~N}$ para a condição padrão e da ordem de $12500 \mathrm{~N}$ para as condições tratadas a laser. Todas as amostras tratadas a laser apresentaram maiores alongamentos em relação à amostra padrão. Foi observado menor módulo de elasticidade para as amostras marcadas e texturizadas a laser para as condições avaliadas.

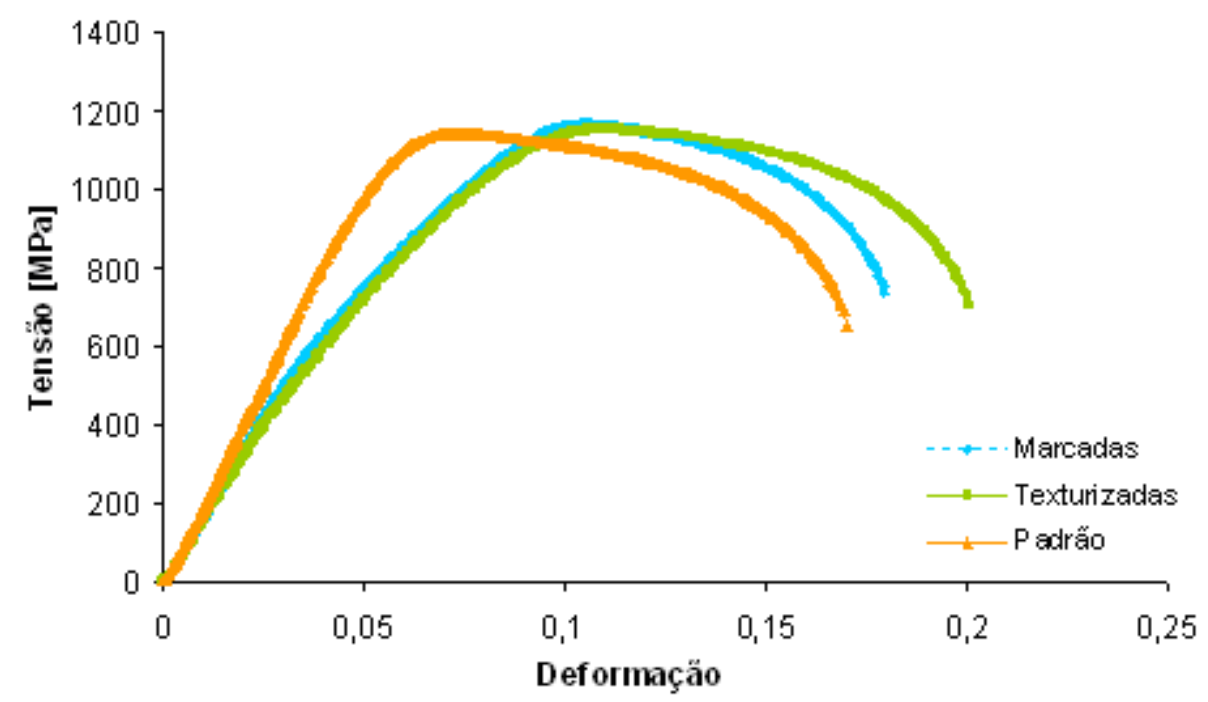

Figura 91. Gráfico da Tensão [MPa] versus Deformação para as três condições de acabamento superficial analisadas. 
A análise dos resultados apresentados no gráfico tensão [MPa] versus deformação indica que as amostras que receberam os tratamentos a laser nas condições citadas anteriormente apresentaram maiores valores de ductilidade do que as amostras sem tratamento (padrão). As tensões máximas obtidas para todas as condições foram em torno de $1100 \mathrm{MPa}$, enquanto que na ruptura foram encontradas tensões da ordem de $650 \mathrm{MPa}$ para a condição padrão e $720 \mathrm{MPa}$ para as condições texturizadas e marcadas a laser, ou seja, os tratamentos com laser não reduziram a tensão de ruptura do biomaterial.

As imagens apresentadas na Figura 92 representam alguns dos corpos-deprova fraturados no ensaio de tração. Para todas as condições avaliadas notouse uma diminuição dos módulos de elasticidade $(E)$ nas amostras tratadas a laser independentemente do tipo de tratamento, quando comparadas às amostras sem tratamentos. Este biomaterial apresentou ruptura dúctil com alta estricção.

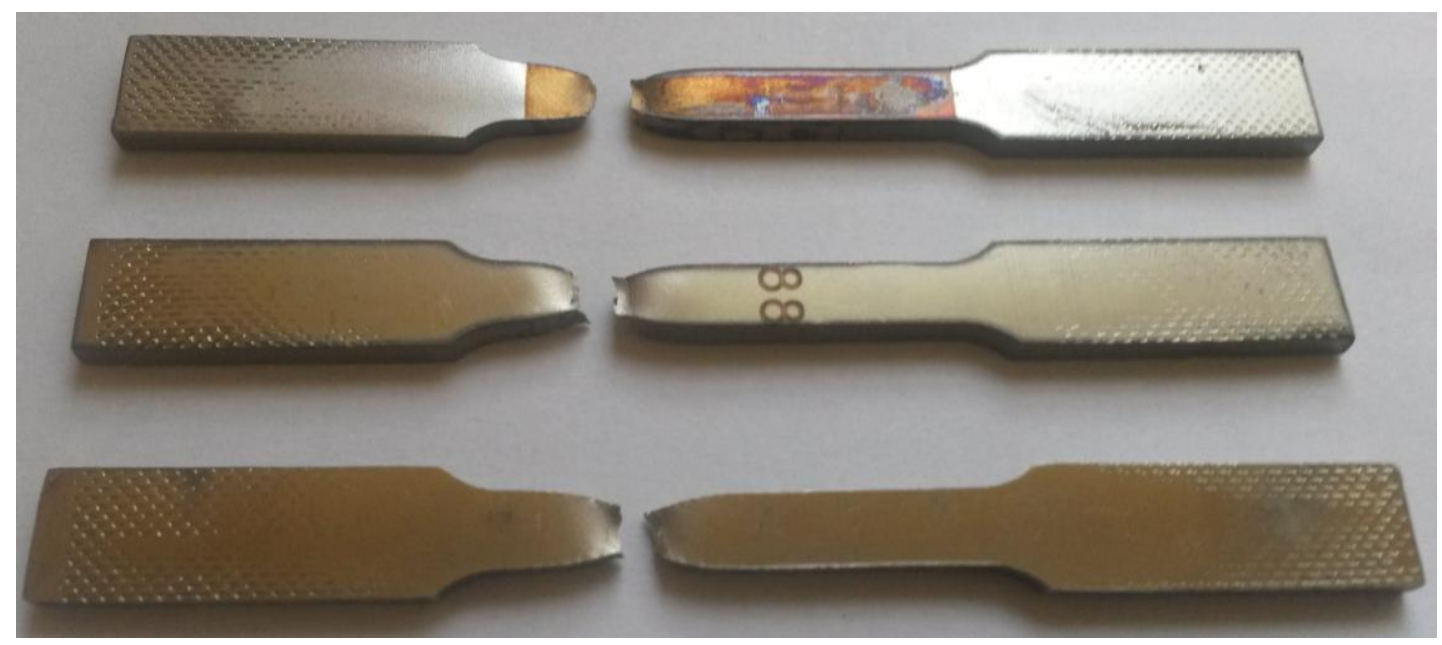

Figura 92. Fraturas dos corpos-de-prova de tração texturizado, marcado e padrão.

\subsubsection{Ensaios Tribológicos}

A análise do comportamento bio-tribológico destes biomateriais, texturizados por feixe laser e na condição padrão de referência, foi efetuada através de ensaios de desgaste em solução de fosfato tamponada (PBS), a fim de simular situações reais encontradas na prática cirúrgica; o que reforça o inedistismo desta pesquisa. $\mathrm{O}$ objetivo deste ensaio é gerar crateras de desgaste na amostra. 
Os parâmetros usados para estas medidas já foram citados anteriormente. Os ensaios tiveram duração total de 2 minutos, com gotejamento de 1 gota a cada 2 segundos e percorreu uma distância equivalente a 8 metros. Os valores obtidos ao término dos ensaios para volume de desgaste $\left[\mathrm{mm}^{3}\right]$ e coeficiente de atrito $[\mu]$ estão apresentados nas Figuras 93 e 94, respectivamente. Na Figura 95 está apresentada uma imagem, obtida por microscopia óptica, da calota de desgaste gerada na superfície da amostra padrão, pelo contra-corpo: esfera de aço inoxidável austenítico 316L.

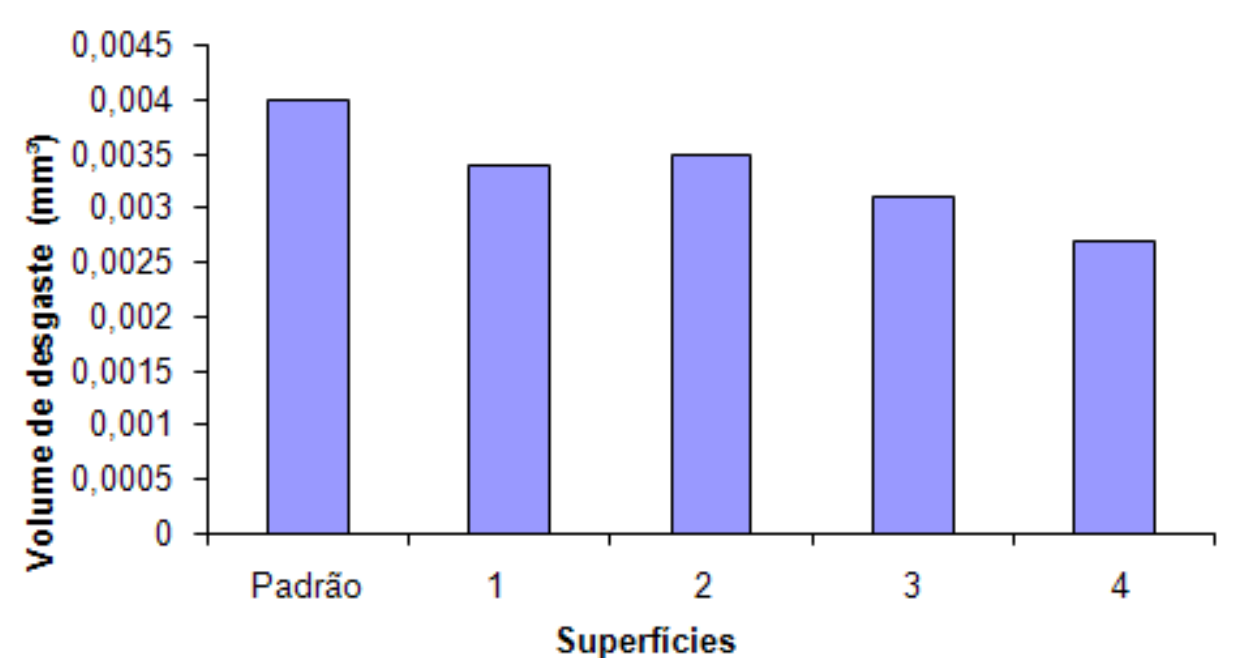

Figura 93. Valores de volume de desgaste em função do tipo de acabamento superficial.

A diminuição nos volumes de desgaste observados para as amostras tratadas a laser em relação à amostra padrão pode ser associado ao aumento de dureza destas superfícies.

Este teste de desgaste em micro-escala (ou ensaio tribológico por esfera) é um método prático para analisar a resistência ao desgaste de diversos materiais [103 - 105]. O teste de desgaste por esfera ganhou grande aceitação em universidades e centros de pesquisa e é amplamente utilizado em estudos focados no comportamento frente ao desgaste abrasivo e micro-abrasivo de diferentes materiais [106 - 109]. 


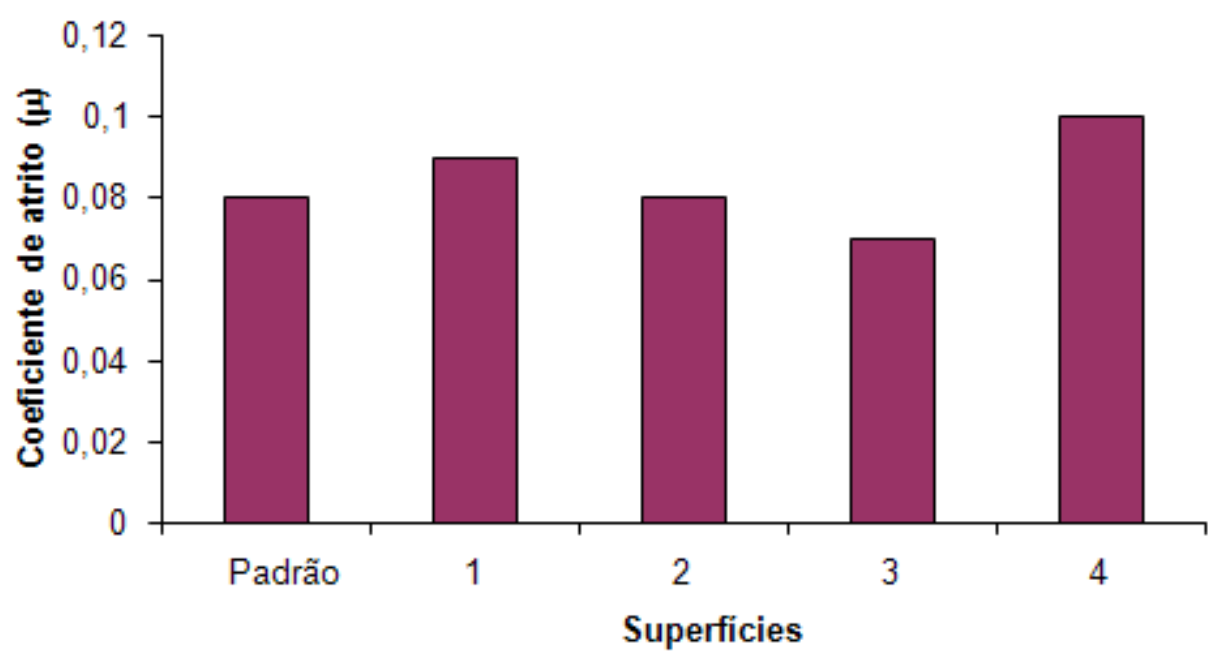

Figura 94. Valores de coeficiente de atrito em função do tipo de acabamento superficial para a amostra padrão e texturizadas por feixe laser.

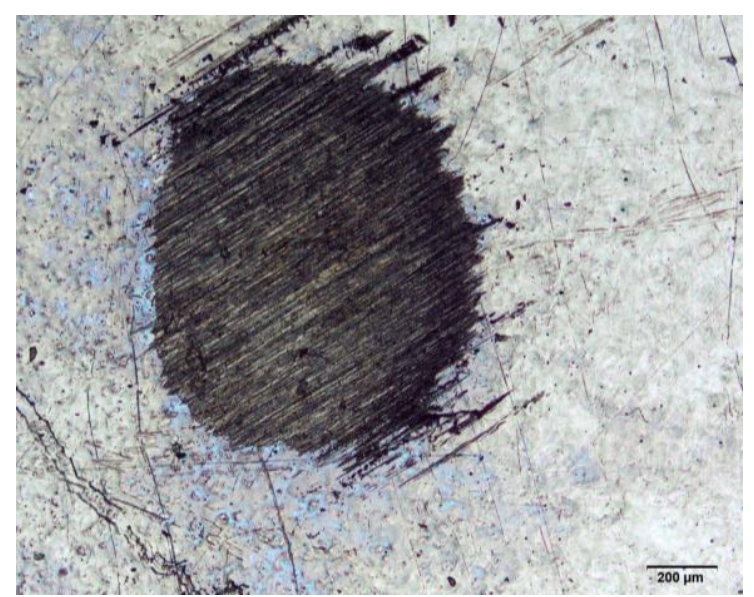

Figura 95. Imagem de cratera de desgaste gerada na superfície da amostra padrão.

Por ser o desgaste um fenômeno de superfície que ocorre na interface entre as naturezas dos materiais em contato, os resultados de biotribologia são fortemente influenciados pelo acabamento superficial produzido pelo feixe laser nas texturizações realizadas. Os maiores valores de volume de desgaste foram relatados para os corpos-de-prova sem texturização a laser. De fato, as texturizações aumentaram a resistência ao desgaste dos corpos-de-prova.

Em relação aos valores de coeficiente de atrito, os maiores valores foram observados junto às condições 1 e 4 de texturização. Valores de tais magnitudes foram reportados por Cozza et al. [107, 109], com o mesmo tipo de ensaio sob diferente sistema tribológico. Não foi observada uma relação direta entre volume de desgaste e coeficiente de atrito, ou seja, o maior valor de volume de desgaste não esteve relacionado ao maior valor de coeficiente de atrito. Os ensaios de 
desgaste realizados com esferas rotativas apresentam vantagens em relação a outros tipos de testes tribológicos, pois podem ser feitos com forças normais $(\mathrm{N})$ e rotações da esfera $(n)$ relativamente baixas $(N<0,5 \mathrm{~N}$ e $n<80$ rpm ) [104 - 107].

No campo dos biomateriais para dispositivos médicos ou odontológicos implantáveis, os ensaios tribológicos são de grande valia por fornecerem uma estimativa das forças normais, tangenciais e coeficientes de atrito em relação ao volume de material que pode ser desprendido da superfície, migração e alojamento de partículas.

Especificamente para este trabalho, foi analisada a evolução do coeficiente de atrito por ensaios de desgaste em nanotribômetro das superfícies dos biomateriais com tratamentos de texturização e marcação por feixe laser. Os resultados obtidos estão apresentados nas Figuras 96 e 97, comparando-se com a amostra padrão (sem tratamento). Os testes foram realizados em 1 minuto, com força normal da ordem de $100 \mathrm{mN}$ e distância percorrida equivalente a 2,4 m, e velocidade de $4,0 \mathrm{~cm} \cdot \mathrm{s}^{-1}$.

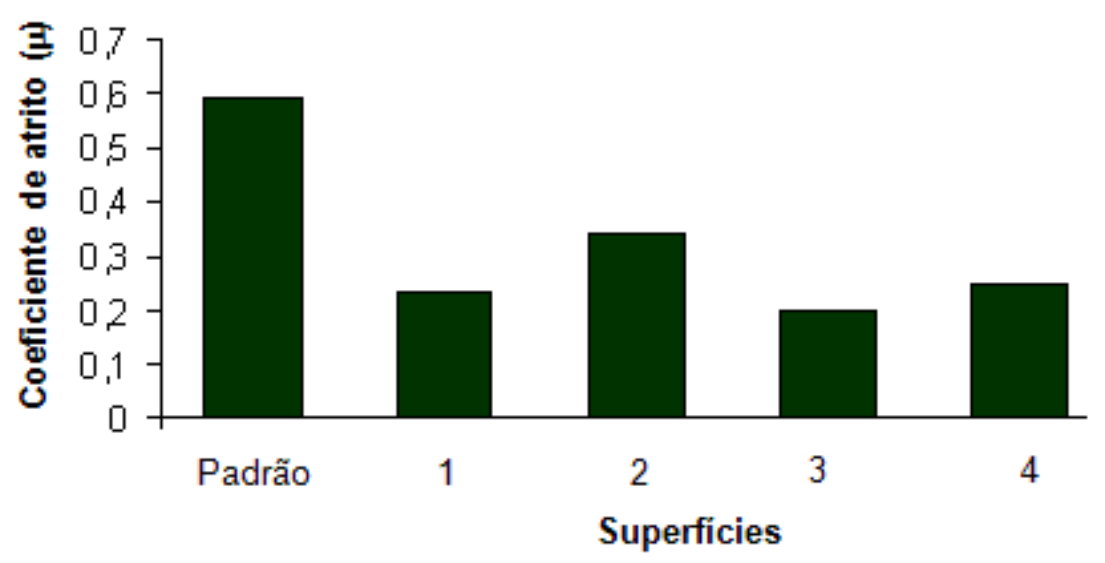

Figura 96. Valores de coeficiente de atrito em função da variação do parâmetro do laser para as amostras texturizadas e padrão de referência.

Os valores obtidos para as condições texturizadas e padrão foram semelhantes aos obtidos no ensaio de desgaste apresentado na Figura 94. Estes resultados apresentam os valores obtidos ao término do ensaio. 


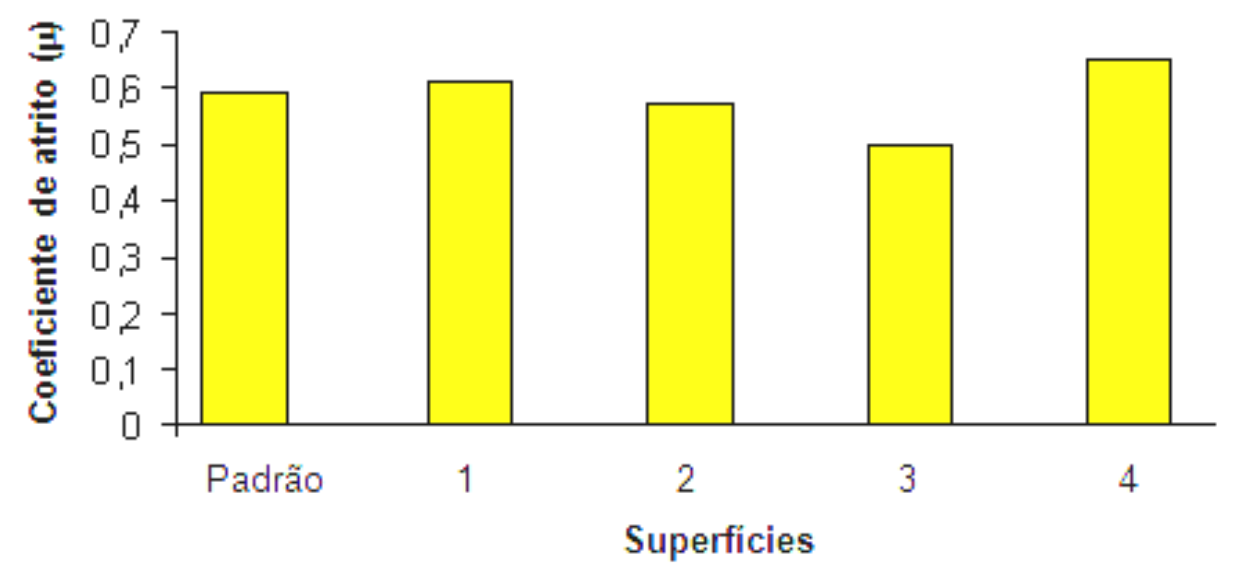

Figura 97. Valores de coeficiente de atrito em função da variação do parâmetro do laser para as amostras marcadas e amostra padrão de referência.

Os valores de coeficiente de atrito obtidos ao final do tempo de ensaio de 1 minuto para as amostras com marcações a laser, apresentado na Figura 97, foram distintos dos obtidos para as condições de texturização; isto pode ser explicado pelo fato da área afetada pelo feixe laser ser muito reduzida (somente a gravação do número "8") em comparação com as amostras texturizadas que receberam um preenchimento total de suas superfícies. Outro fator importante é o posicionamento do contra-corpo (esfera) por sobre a amostra. Nota-se que para a condição de marcação a laser, os valores de coeficiente de atrito obtidos são mais próximos dos da amostra sem tratamento por feixe laser.

A diminuição do coeficiente de atrito para as amostras texturizadas a laser, apresentado na Figura 96, ocorre devido à formação de um filme hidrodinâmico. Nas amostras marcadas, este efeito é mínimo; ou não ocorre a formação de um filme contínuo, semelhantemente às amostras sem tratamento (padrão).

Os implantes utilizados nas articulações do corpo humano requerem biocompatibilidade com os órgãos e tecidos adjacentes, resistência mecânica e, resistência à corrosão. Vale ressaltar que os fluidos corpóreos constituem um ambiente hostil para o implante, que está sujeito a vários carregamentos.

O implante, devido à corrosão, corrosão associada à fadiga e, mesmo ao atrito com ossos e outras partes do corpo humano, pode desprender partículas que, entrando em contato com os fluidos corpóreos, são capazes de serem alojadas em locais bem distantes dos de desprendimento. 
As propriedades dos biomateriais metálicos no tocante ao efeito do atrito na polarização anódica foram investigadas por Okazaki [110] utilizou ligas de titânio, cobalto e o aço inoxidável SUS 316L. Ele constatou que durante o atrito, as densidades de corrente eram superiores às encontradas em condições estacionárias. O pesquisador observou também uma faixa de densidades de corrente flutuante, causada pela formação e quebra do filme passivo.

Para o aço inoxidável SUS 316L, esta flutuação foi observada na região passiva; assim considerou que em um ambiente onde existe a possibilidade de atrito, a zona sujeita às maiores tensões é a anódica e a adjacente, catódica.

Observou-se queda do potencial de corrosão em circuito aberto para o aço inoxidável SUS 316L. Ele conclui que quanto mais estável era o filme passivo formado sobre a superfície de um implante, melhor a resistência à corrosão e menor era o desprendimento de íons metálicos destas superfícies [110].

Efeito semelhante foi encontrado nos biomateriais metálicos com tratamentos a laser.

A realização de ensaio de ativação neutrônica é importante para se determinar a quantidade de elementos químicos que se desprendeu da superfície do biomaterial texturizada a laser e que migrou para a solução após ensaio eletroquímico.

Os valores de coeficiente de atrito não foram constantes ao longo do período de ensaio tribológico, como pode ser imaginado ao se verificar os resultados apresentados anteriormente. Este efeito foi pesquisado e os resultados da variação do coeficiente de atrito em função do tempo de ensaio estão apresentados nas Figuras 98 e 99, para as amostras texturizadas e marcadas por feixe laser, respectivamente, nas condições citadas anteriormente, comparandoas com a amostra padrão de referência. 


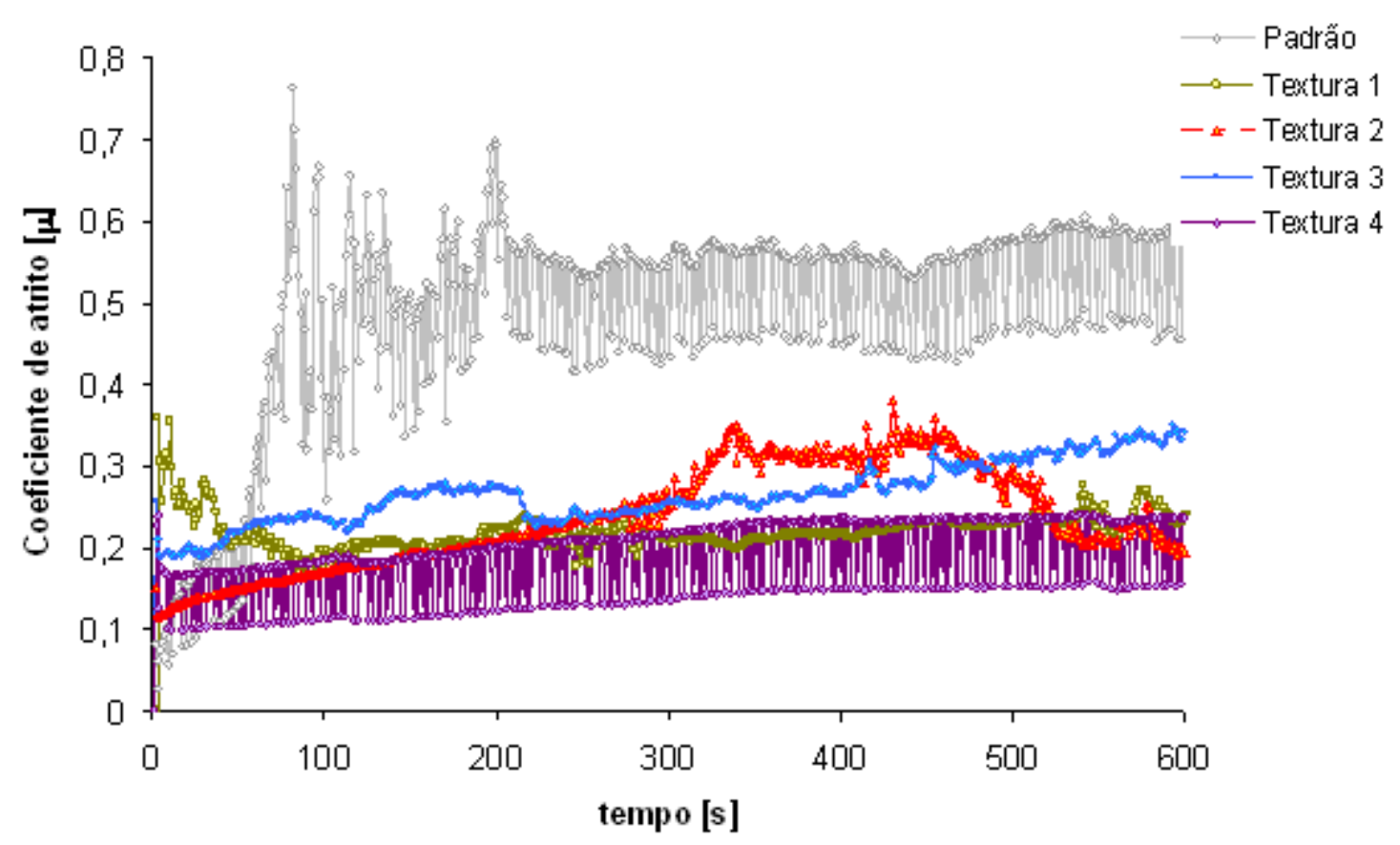

Figura 98. Variação de coeficiente de atrito $[\mu]$ em função do tempo [s] de ensaio para as amostras texturizadas a laser e padrão.

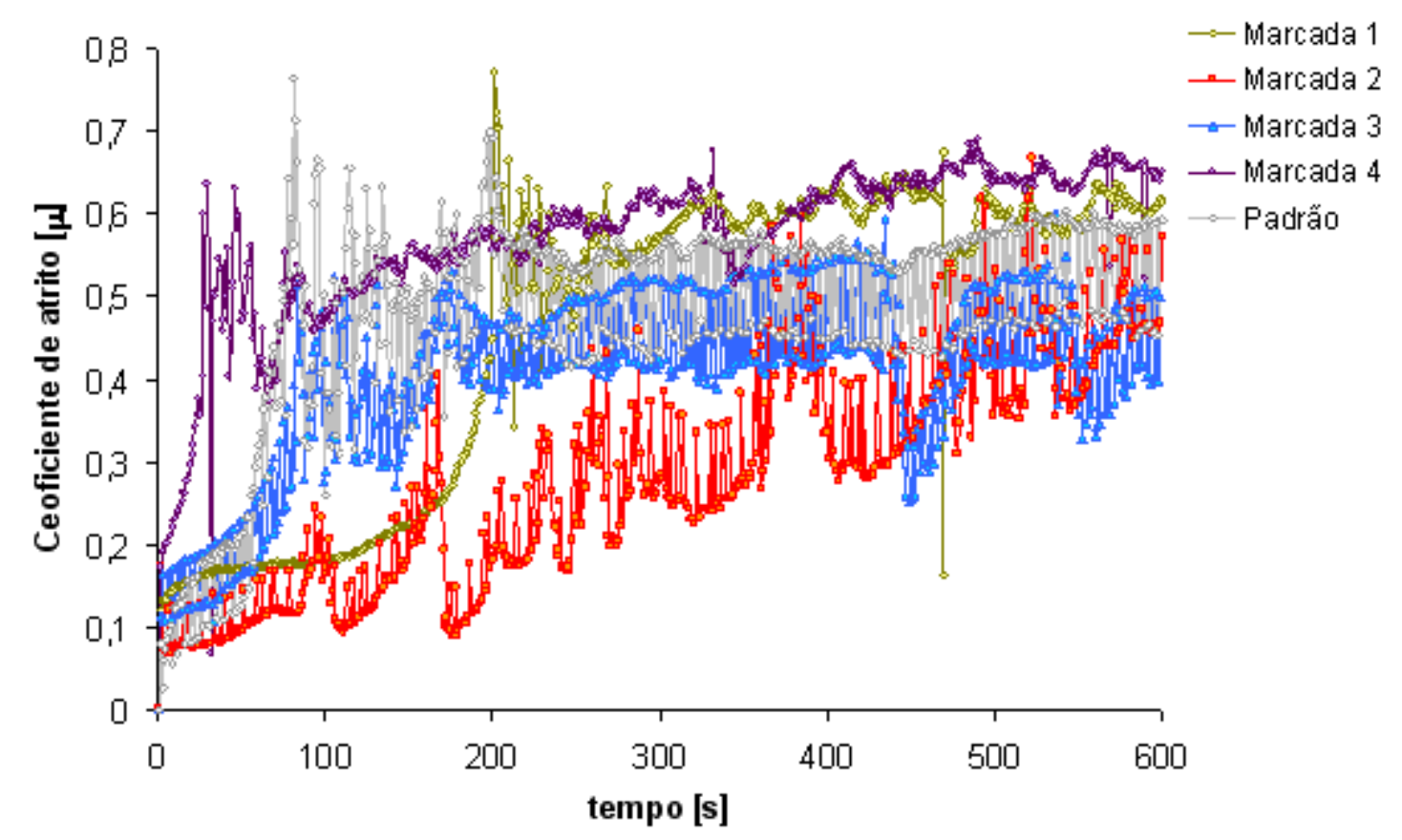

Figura 99. Variação de coeficiente de atrito $[\mu]$ em função do tempo [s] de ensaio para as amostras marcadas a laser e padrão.

Para a condição de superfícies com marcação a laser, Figura 99, os valores de coeficiente de atrito obtidos são mais próximos dos obtidos nas amostras sem tratamento por feixe laser; diferentemente do que ocorre para as amostras texturizadas por feixe laser, Figura 98. 
Os valores de coeficiente de atrito para as amostras sem tratamento apresentam uma rápida elevação nos primeiros períodos de ensaio, e praticamente se estabilizam em torno de valores próximos a $\mu=0,5$, devido à superfície estar menos rugosa. No caso das amostras texturizadas a laser, a amostra 1 apresentou ligeira queda nos primeiros tempos de ensaio, seguido de estabilização do coeficiente de atrito. A amostra 2 apresentou aumento do coeficiente até valores próximos de $\mu=0,35$, decaindo ao final do teste. A amostra 3 mostrou uma tendência à contínua elevação do coeficiente; enquanto que para a amostra 4, este se manteve praticamente constante e nos valores mais baixos, comparando-se com as demais condições.

Para todas as condições de amostras com marcação por feixe laser houve aumento do coeficiente de atrito em função do tempo de ensaio; sendo os valores mais elevados obtidos para a amostra 4.

O efeito da variação do coeficiente de atrito em função do tempo de ensaio foi estudado por Huang et al. [111]. Eles verificaram propriedades tribológicas em ligas de Ti-6Al-4V com e sem recobrimento ("laser clad"), por período de $3500 \mathrm{~s}$ em diferentes frequências de rotação, ao término dos ensaios verificaram que 0 coeficiente de atrito para o recobrimento foi sempre inferior ao do substrato.

\subsection{Avaliação de Citotoxicidade}

Por serem estes biomateriais já utilizados na confecção de implantes, e próteses, mas por não se conhecer implicações do laser em suas propriedades referentes à biocompatibilidade, foram executados ensaios de citotoxicidade, em amostras destes biomateriais com os vários parâmetros de tratamento a laser, bem como em amostras de referência, sem laser.

O interesse nesta avaliação está principalmente na determinação do comprometimento das células adjacentes ou não aos implantes ortopédicos, seja pelo contato direto com os tecidos ou pela possível dissolução de partículas devido à degradação oriunda dos processos bio eletroquímicos e biotribológicos. Este tipo de avaliação trata-se de mais uma originalidade desta pesquisa.

O sistema-teste utilizado consistiu em células da linhagem CHO-K1 derivado de ovário de hamster chinês de formato epitelial. Os resultados 
encontram-se na Figura 100, onde o índice $M$ se refere às amostras com marcações e, o índice $T$, às amostras com texturizações.

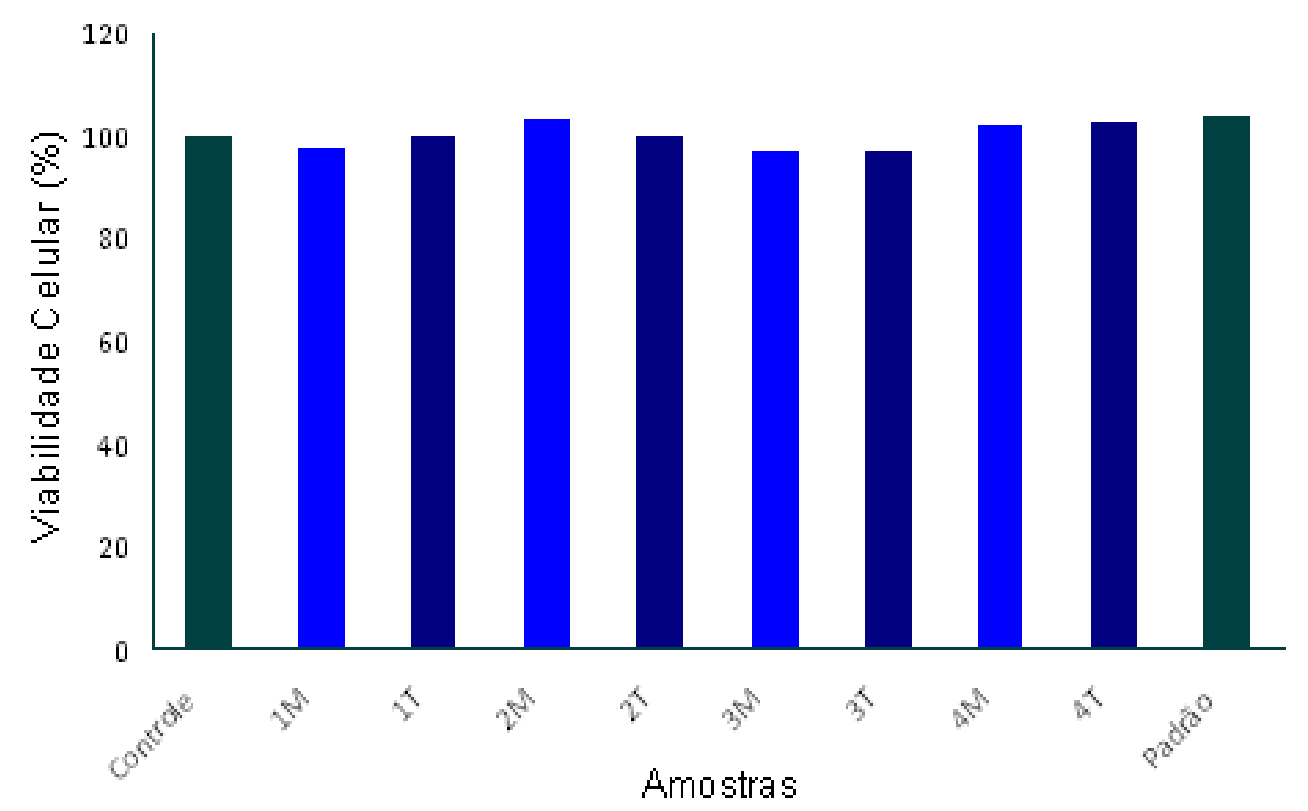

Figura 100. Gráfico de viabilidade celular (\%) por tipo de amostra.

As amostras foram posicionadas em condição que somente a superfície em análise ficasse em contato com o meio de cultura das células. Considera-se viabilidade celular igual a $100 \%$ para a amostra controle.

De acordo com esta técnica, o biomaterial é tido como citotóxico se apresentar viabilidade celular abaixo de $70 \%$ para os extratos puros e abaixo de $50 \%$ para extratos diluídos.

Nenhuma amostra foi considerada citotóxica com o extrato puro, por isso não foi realizada a diluição dele. Nota-se que as amostras: padrão, 2M, 4M e 4T apresentaram viabilidade celular acima da amostra controle. As amostras $1 \mathrm{M}, 3 \mathrm{M}$ e $3 T$ apresentaram os menores valores de viabilidade celular, entretanto não podem ser consideradas citotóxicas.

Os tratamentos de texturização e marcação por feixe laser, nas condições estudadas, podem ser empregados nas superfícies deste biomaterial sem detrimento de sua biocompatibilidade em razão de suas características citotóxicas. 


\subsection{Avaliação de Susceptibilidade Magnética}

Foram realizados ensaios para a avaliação de susceptibilidade magnética das amostras tratadas por feixe laser. Em razão das marcações e texturizações serem muito rápidas, com duração do pulso de laser da ordem de nanossegundos, e por apresentarem diminuição da resistência à corrosão localizada, considerou-se a formação de fase ferrita delta nas áreas tratadas por feixe laser.

A força magnética exercida pela amostra sobre o imã altera a leitura do peso [112]. Esta propriedade foi medida antes e depois dos tratamentos de marcação e texturização a laser, utilizando um imã de $\mathrm{NdFeB}$ cúbico de 6,3 mm de aresta com momento magnético de $m_{d}=0,2518 \mathrm{Am}^{2}$. Uma amostra não foi tratada, e foi mantida como referência para o ajuste do equipamento de medição antes de cada caracterização magnética. Parâmetros do laser foram alterados para cada amostra, conforme citados anteriormente.

A força magnética média medida sobre o ímã de $-1,47 \cdot 10^{-3} \mathrm{~N}(150 \mathrm{mg}$ na leitura da balança), indica uma permeabilidade $\mu_{r}=1,00232$ para o material de base (material paramagnético). A gravação nos discos aumenta esta força (face gravada voltada para o imã) com $\mu_{r}=1,00233$. No caso das amostras texturizadas o efeito é mais intenso, com a variação da força chegando $\mu_{r}=$ 1,00235. As medidas são muito sensíveis em relação à distância entre o imã e o corpo de prova, e ao seu estado de magnetização inicial.

Apesar da camada alterada pelo laser ser da ordem de micrômetros, ainda assim é possível detectar fases ferromagnéticas (ferrita delta) pelo aumento na permeabilidade magnética. Os resultados estão apresentados na Tabela $18 \mathrm{e}$ correspondem à média aritmética de duas medições para cada condição de acabamento superficial. A última coluna (direita) corresponde à média entre todos os valores de todas as condições de acabamento superficial analisados.

$\mathrm{Na}$ Tabela 19 estão apresentados os resultados comparando as faces analisadas, a saber, a face texturizada em relação à face marcada, para todas as condições avaliadas. Foram calculadas: as diferenças de forças entre as faces, variação em relação à média, relação de permeabilidade magnética entre as faces, variação de permeabilidade em relação à média bruta e em percentual. 
Tabela 18. Medidas de força e permeabilidade magnética para as amostras marcadas e texturizadas a laser.

\begin{tabular}{c|c|c|c|c|c|c}
\hline Texturizadas & $\mathbf{1}$ & $\mathbf{2}$ & $\mathbf{3}$ & $\mathbf{4}$ & Padrão & Média \\
\hline F [mgf] & 92,520 & 93,140 & 92,555 & 93,540 & 92,375 & 92,826 \\
\hline Permeabilidade & 1,002327 & 1,002343 & 1,002328 & 1,002353 & 1,002323 & 1,002335 \\
\hline Marcadas & & & & & & \\
\hline F [mgf] & 92,375 & 92,080 & 92,445 & 92,550 & 92,220 & 92,334 \\
\hline Permeabilidade & 1,002323 & 1,002316 & 1,002325 & 1,002328 & 1,002319 & 1,002322 \\
\hline
\end{tabular}

Tabela 19. Comparação entre as faces texturizadas (T) e marcadas (M) por feixe laser nos parâmetros das amostras 1, 2, 3 e 4.

\begin{tabular}{|c|c|c|c|c|}
\hline Avaliação \Amostra & 1 & 2 & 3 & 4 \\
\hline $\mathrm{F}_{\mathrm{T}}-\mathrm{F}_{\mathrm{M}}[\mathrm{mgf}]$ & 0,145 & 1,060 & 0,110 & 0,990 \\
\hline $100 \%{ }^{*}\left(F_{T}-F_{M}\right) /$ Fmédia $M(\%)$ & 0,19 & 0,87 & 0,40 & 1,31 \\
\hline susc. $\mathrm{T} /$ susc. $\mathrm{M}=\left(\right.$ perm. $\left.\mathrm{T}^{-1}\right) /\left(\right.$ perm. $\left.\cdot \mathrm{M}^{-1}\right)$ & 1,0016 & 1,0115 & 1,0012 & 1,0107 \\
\hline susc. T/ susc. média M & 1,0020 & 1,0087 & 1,0024 & 1,0131 \\
\hline $100 \%{ }^{*}($ susc. ) / (susc. média M-1) (\%) & 0,20 & 0,87 & 0,24 & 1,31 \\
\hline
\end{tabular}

Os tratamentos realizados afetaram a susceptibilidade magnética das superfícies, sendo esta maior para as amostras texturizadas quando comparadas às demais condições de acabamento superficial, o que é indesejável para um biomaterial. As amostras texturizadas a laser apresentaram maior aumento de permeabilidade magnética do que as amostras marcadas; isto se deve ao maior volume afetado pelo laser nas amostras texturizadas, uma vez que possuem as superfícies totalmente preenchidas por linhas justapostas que compõem a texturização. Avaliando-se apenas os valores médios obtidos entre as amostras tratadas com diferentes parâmetros do laser, nota-se que as forças magnéticas são maiores para as amostras texturizadas do que as marcadas a laser e, em ambos os casos, são maiores do que as amostras utilizadas como padrão de referência. Nas comparações realizadas entre as faces texturizadas e marcadas, apresentadas na tabela 18, notam-se variações da ordem de $0,2 \%$ para amostras tratadas com os parâmetros 1 e da ordem de 1,3 \% para as tratadas com os parâmetros 4 . 


\subsection{Caracterização de Campo Magnético por Microscopia de Força Magnética (MFM)}

A técnica de microscopia de força magnética (MFM) foi utilizada para a obtenção de imagens de variação do campo magnético ao longo das superfícies de amostras dos biomateriais tratados por texturização a laser nos parâmetros citados anteriormente. Para tanto, se fez necessário o uso de uma ponta recoberta por um filme fino de material ferromagnético, com imantação permanente. A ponta, posicionada no cantiléver, oscila próximo à superfície da amostra, mas sem tocá-la, com oscilação entre 1 e $10 \mathrm{~nm}$, detectando mudanças na frequência de ressonância do cantiléver; desta forma é possível perceber a interação do campo magnético da ponta com o campo magnético que emana da amostra. A força magnética gera uma perturbação no movimento oscilatório.

Com esta técnica foram gerados cinco mapas distintos para cada uma das condições de texturização por laser: altura que corresponde à topografia da superfície obtida por tapping mode, erro, variação de fase entre a força atuante no cantiléver e o movimento oscilatório do cantiléver, RMS da amplitude de oscilação do cantiléver devido ao sinal magnético das superfícies e frequência de ressonância do cantiléver em razão da interação com o campo magnético presente na amostra. Foi utilizado o recurso interleave com lift mode para que não se tivesse a contribuição da morfologia das superfícies nas imagens de MFM. Os resultados de MFM são de caráter qualitativo.

$\mathrm{Na}$ literatura esta técnica é empregada para a detecção de fase ferrítica em aços inoxidáveis [113]. Na Figura 101 estão apresentadas imagens de microscopia óptica das regiões selecionadas em cada amostra, com detalhe da sonda, e os mapas gerados nas análises. Nas Figuras 102 a 106 estão apresentados os resultados para a amostra texturizada na condição 1, tratada com frequência de pulso $f=80 \mathrm{kHz}$. 


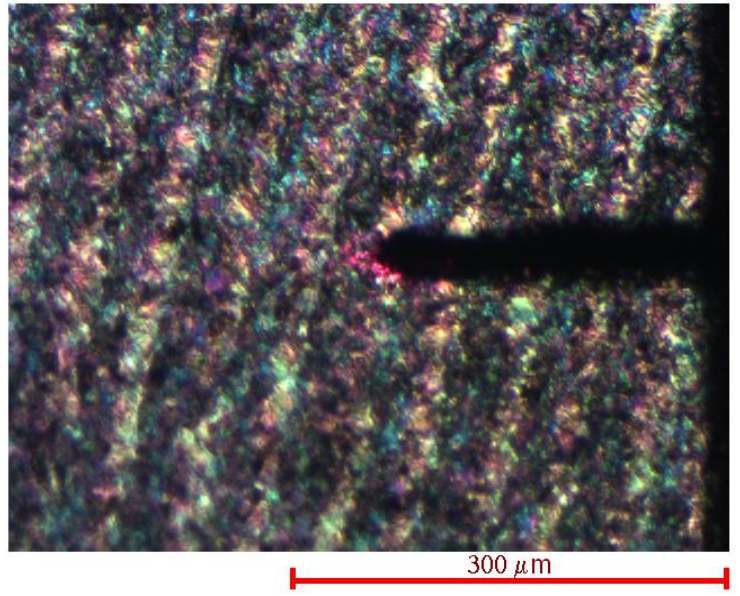

(a) Amostra 1

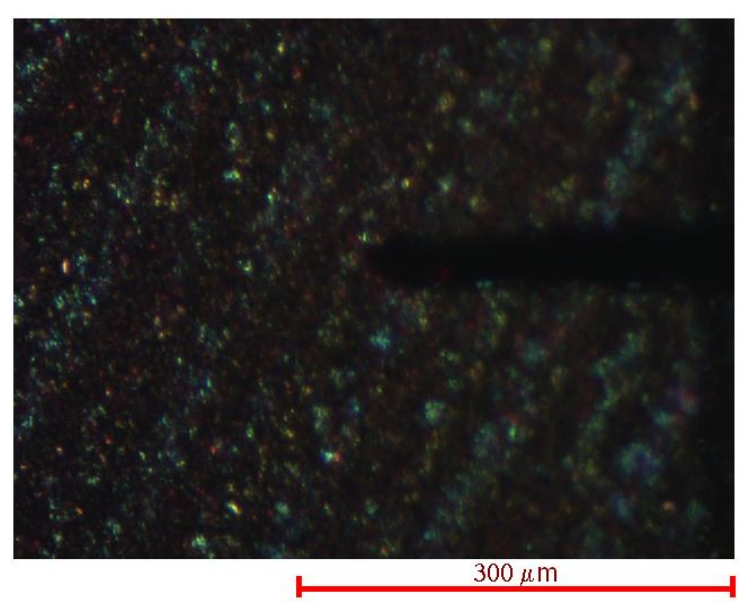

(c) Amostra 3

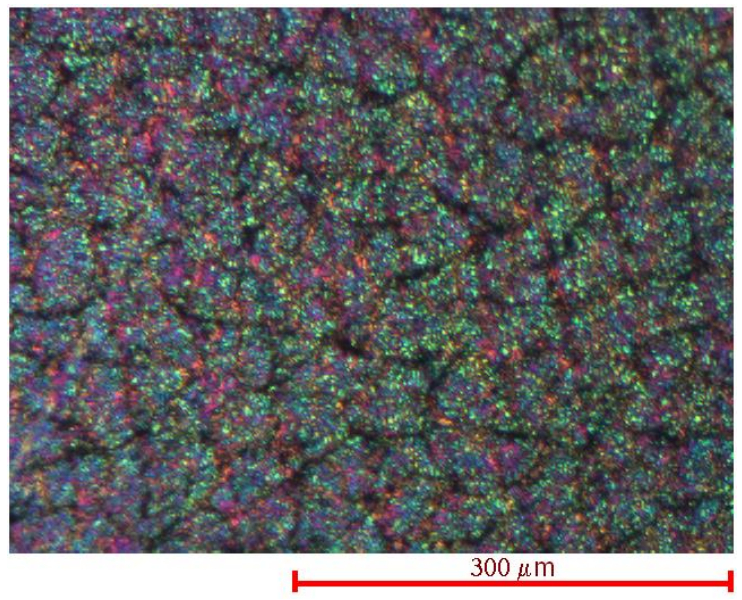

(b) Amostra 2

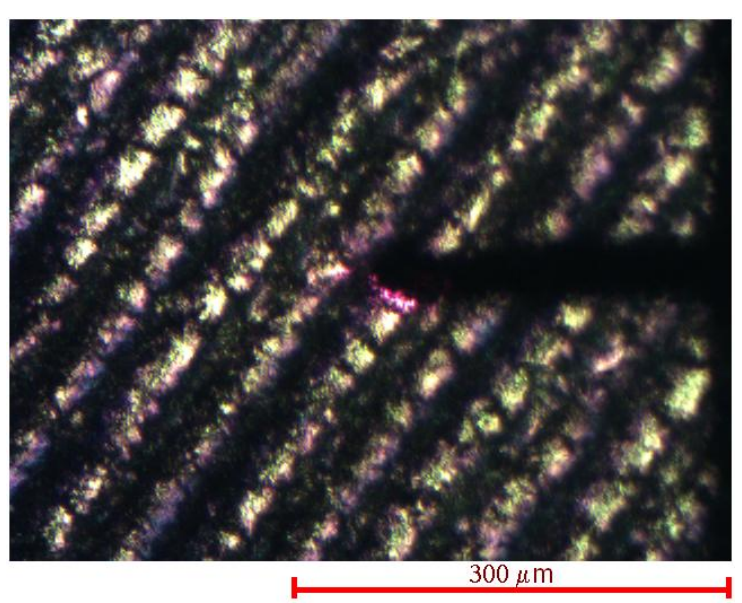

(d) Amostra 4

Figura 101. Regiões das superfícies dos biomateriais texturizadas a laser, selecionadas para análise por MFM e detalhe da sonda. 


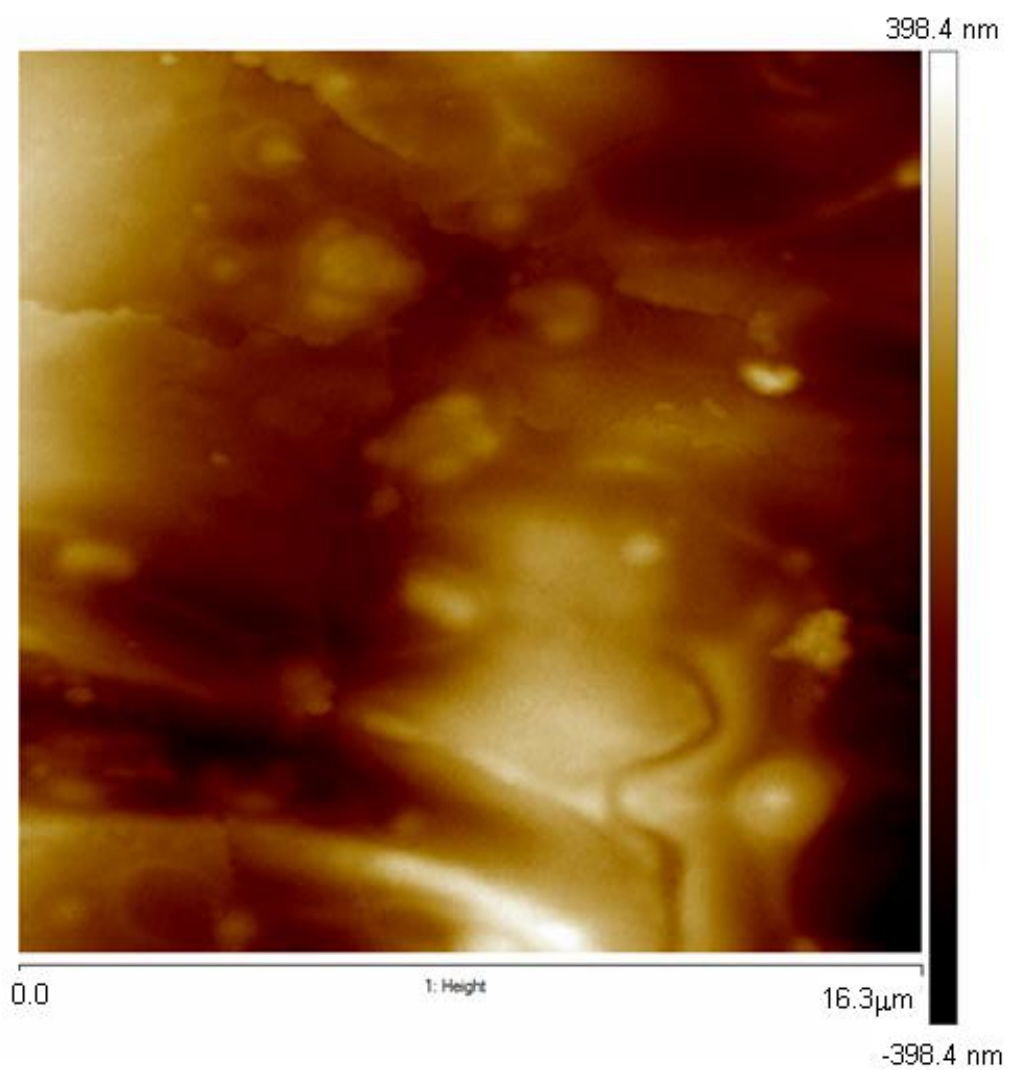

Figura 102. Imagem obtida por AFM (tapping mode) da topografia (alturas) da região analisada na superfície da amostra 1.

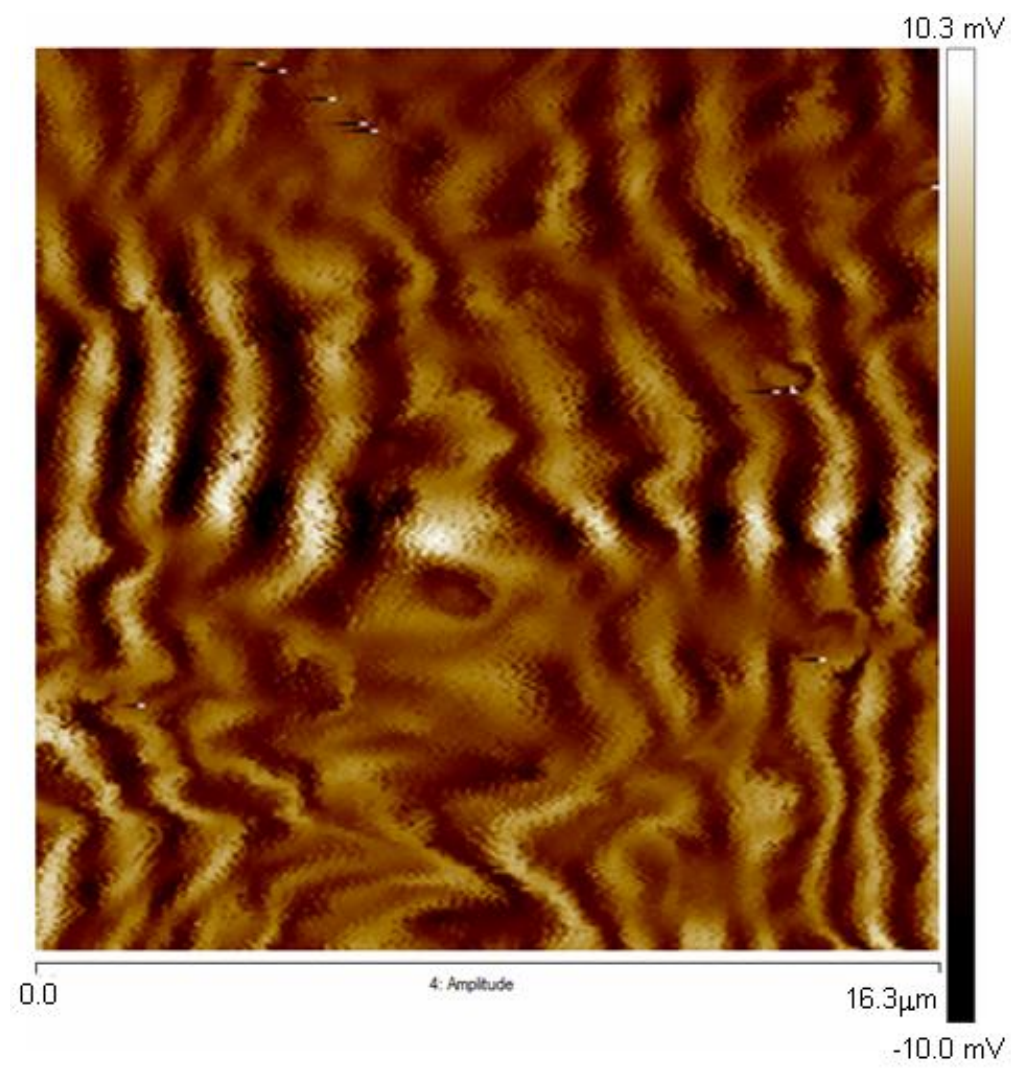

Figura 103. Imagem obtida por MFM da amplitude do campo magnético detectado na região selecionada na superfície da amostra 1. 


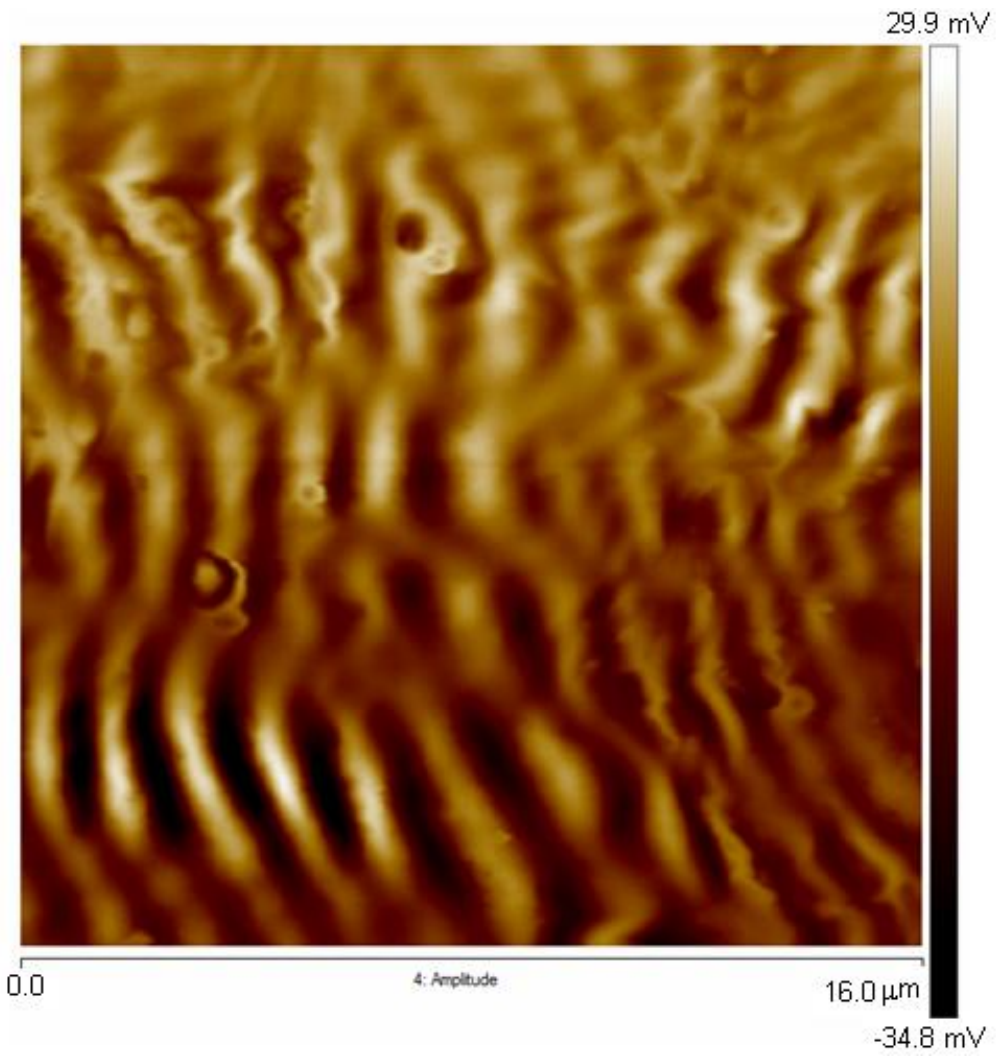

Figura 104. Imagem da amplitude do campo magnético detectado na região selecionada na superfície da amostra 1. Medida em região adjacente à apresentada anteriormente.

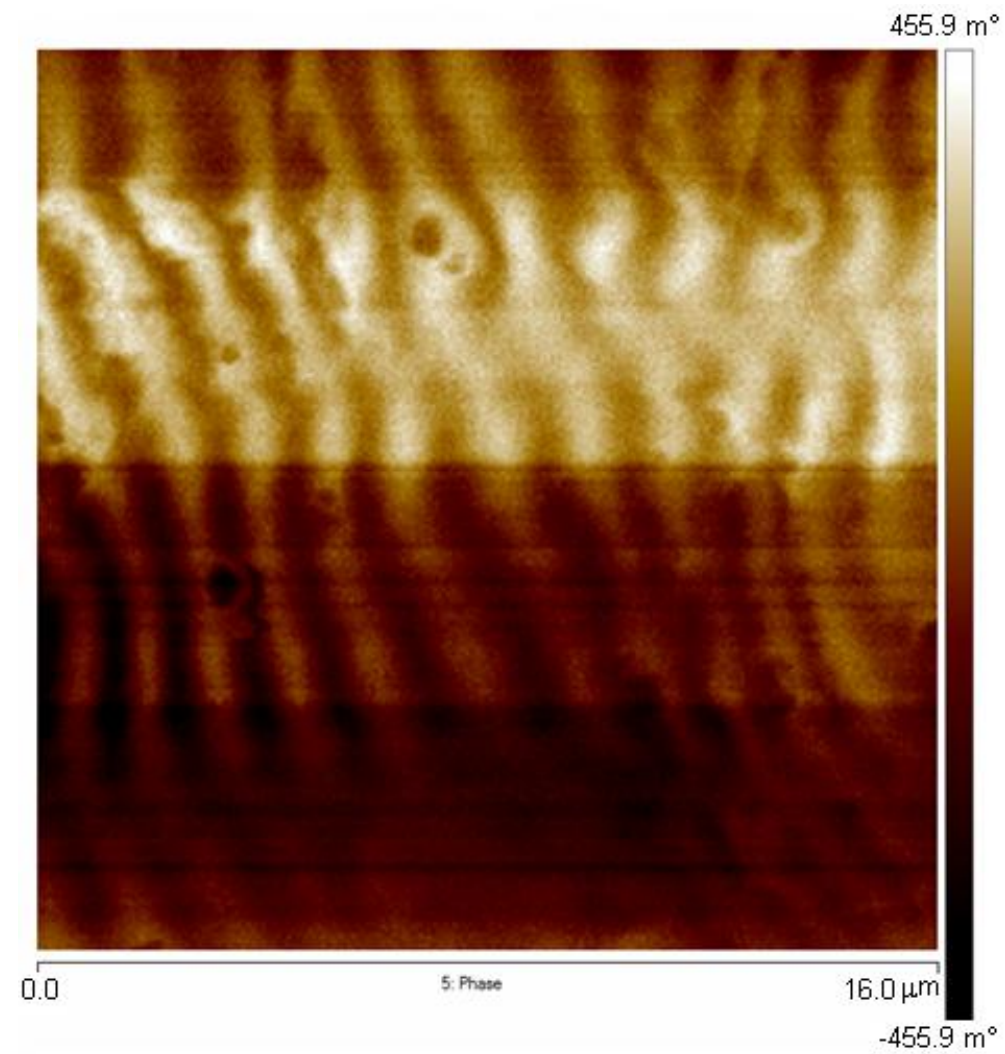

Figura 105. Imagem da diferença de fases detectada na superfície da amostra 1. 


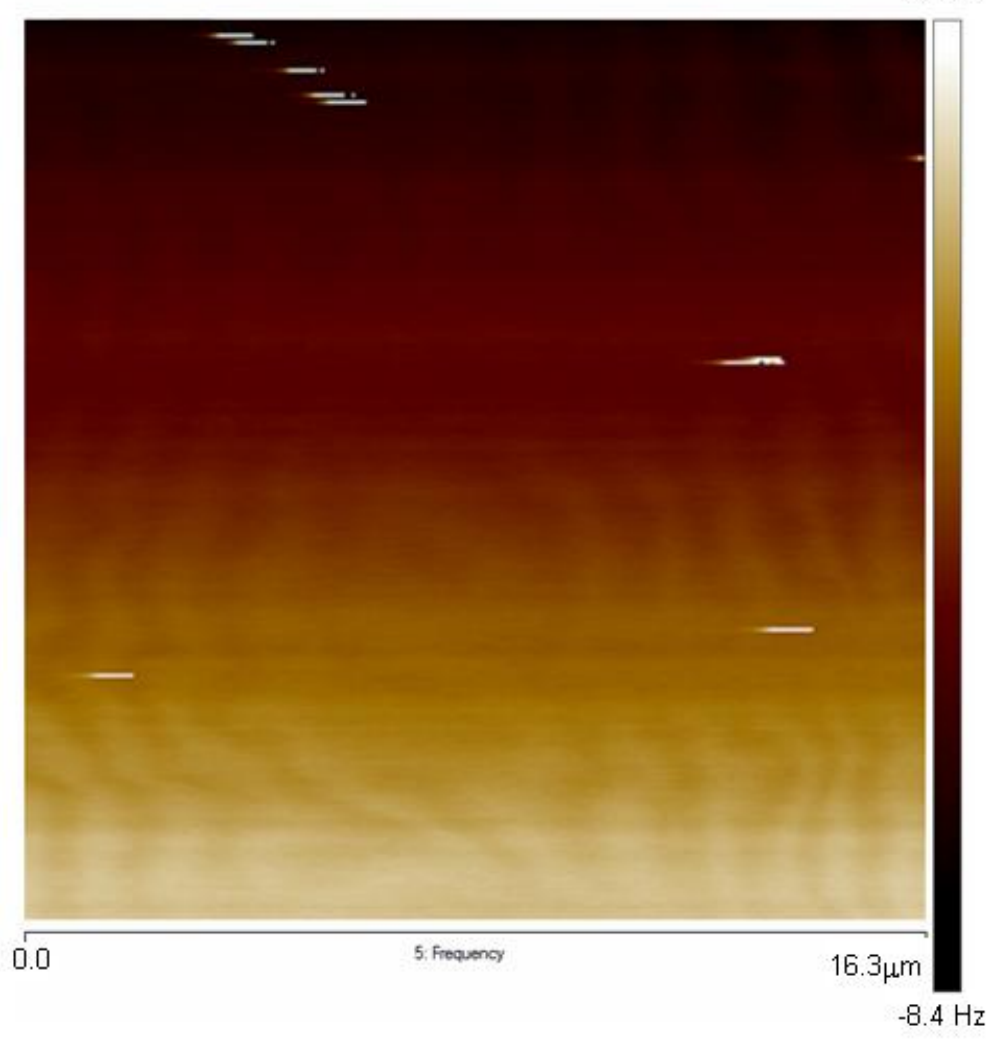

Figura 106. Imagem da frequência do sinal do campo magnético presente na amostra 1.

As imagens geradas por microscopia de força magnética (MFM) para a frequência do sinal do campo magnético foram pouco reveladoras desse comportamento; em razão da pouca nitidez das imagens obtidas, os resultados para as demais amostras não estão apresentados nas figuras seguintes.

Nas Figuras 107 a 109 estão apresentados os resultados para a amostra 2, tratada com frequência de pulso $f=188 \mathrm{kHz}$. 


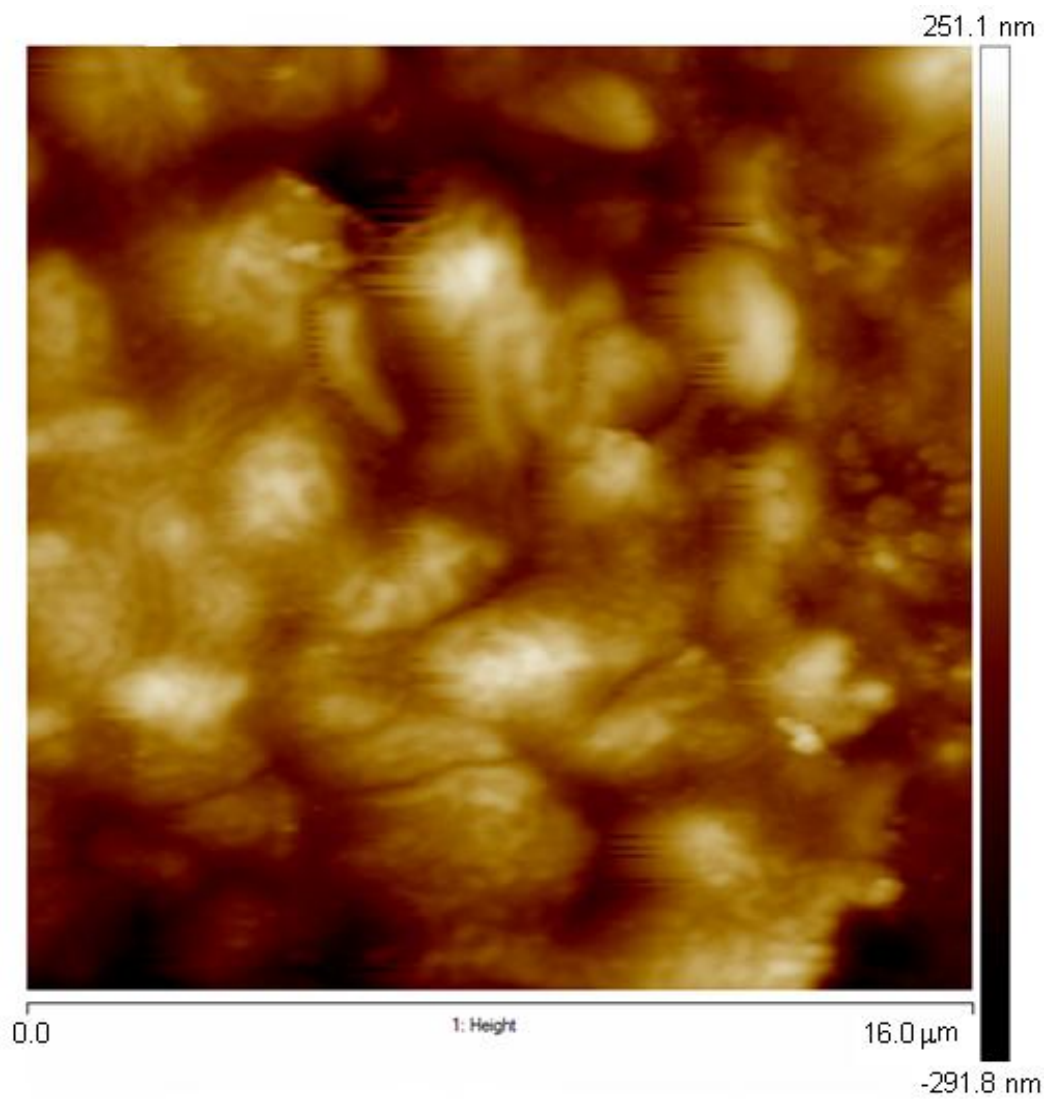

Figura 107. Imagem obtida por AFM (tapping mode) da topografia (alturas) da região analisada na superfície da amostra 2.

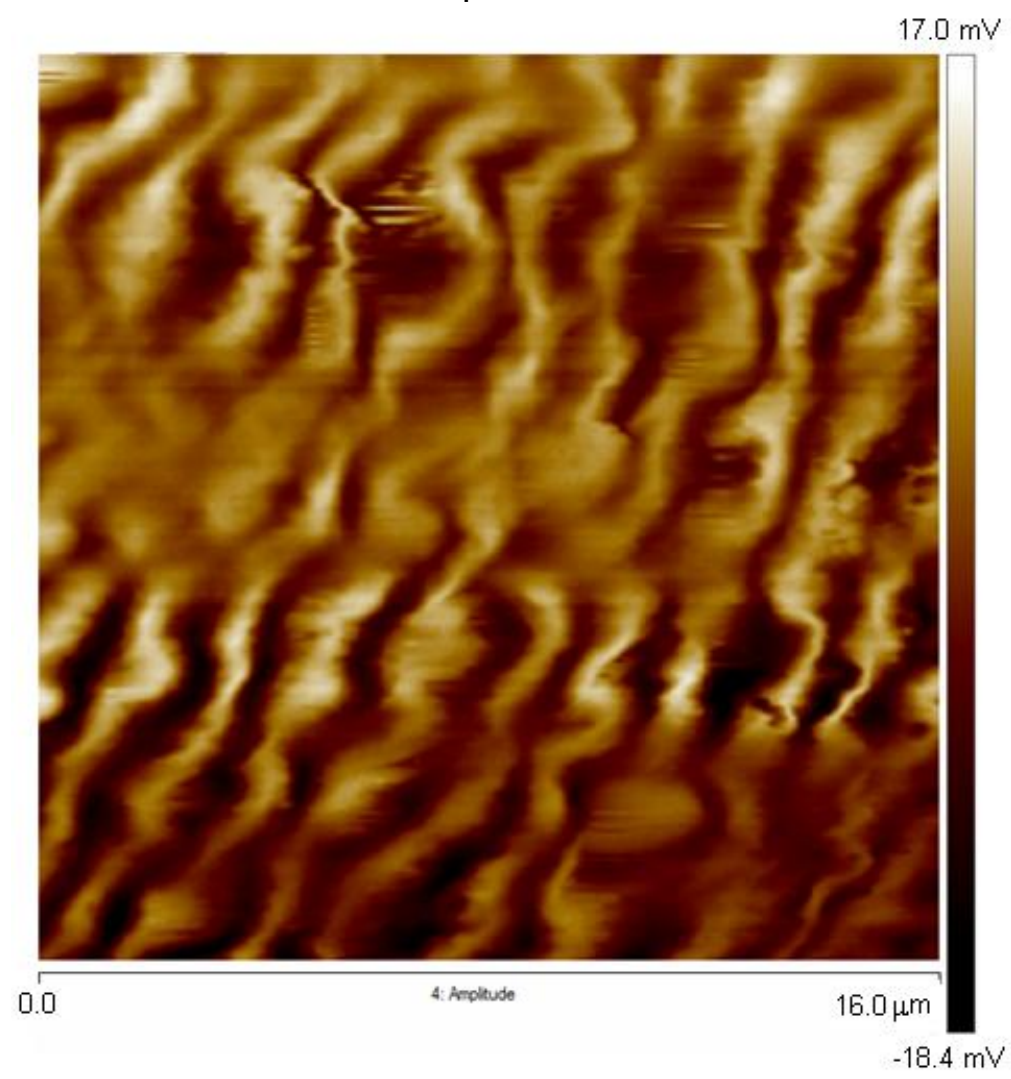

Figura 108. Imagem obtida por MFM da amplitude do campo magnético detectado na região selecionada na superfície da amostra 2. 


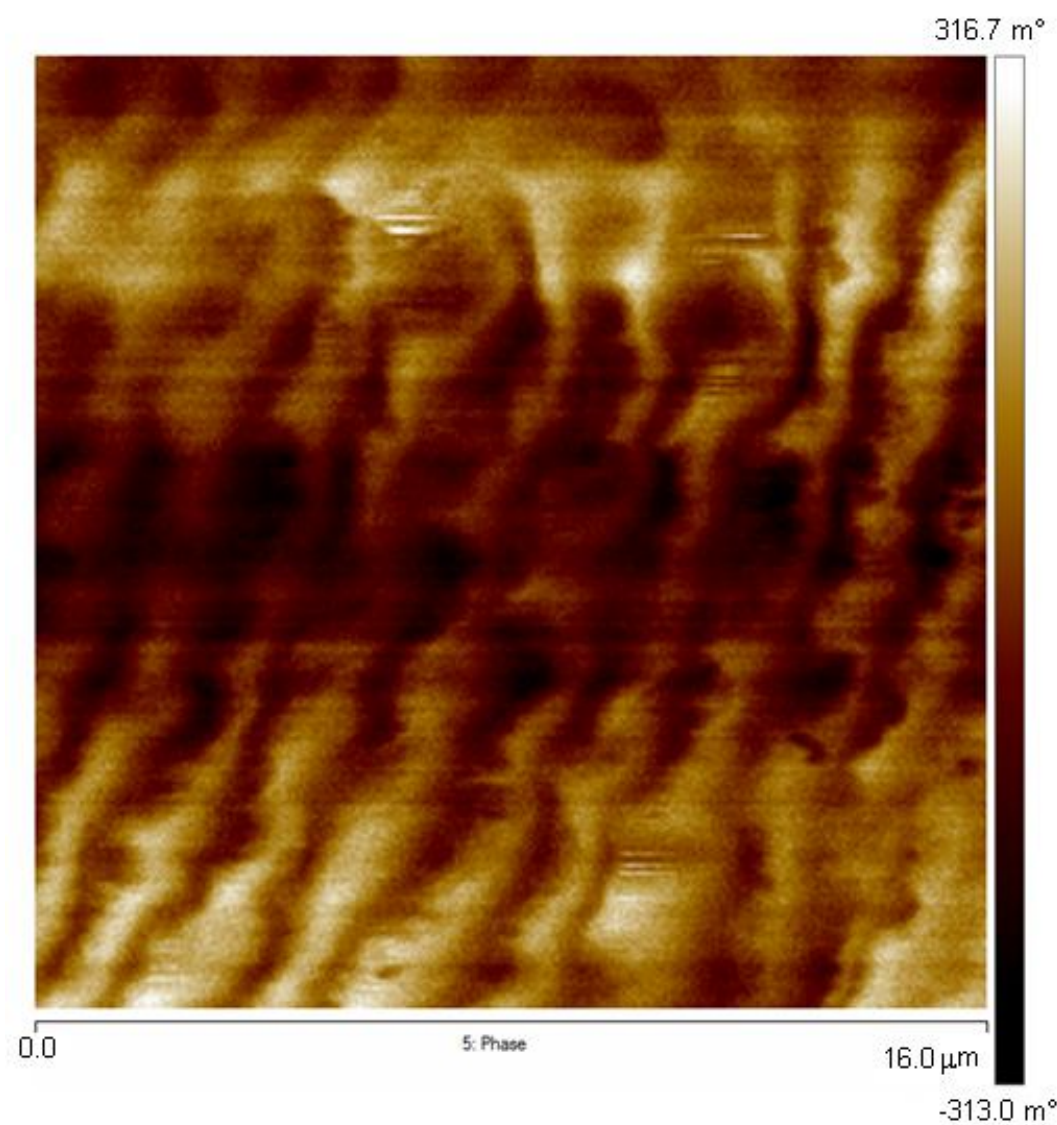

Figura 109. Imagem da diferença de fases detectada na superfície da amostra 2.

Nas Figuras 110 a 112 estão apresentados os resultados qualitativos obtidos para as condições de texturização por feixe laser referentes à amostra 3 , que recebeu tratamento a laser com frequência $f=296 \mathrm{kHz}$. 
$1.5 \mu \mathrm{m}$

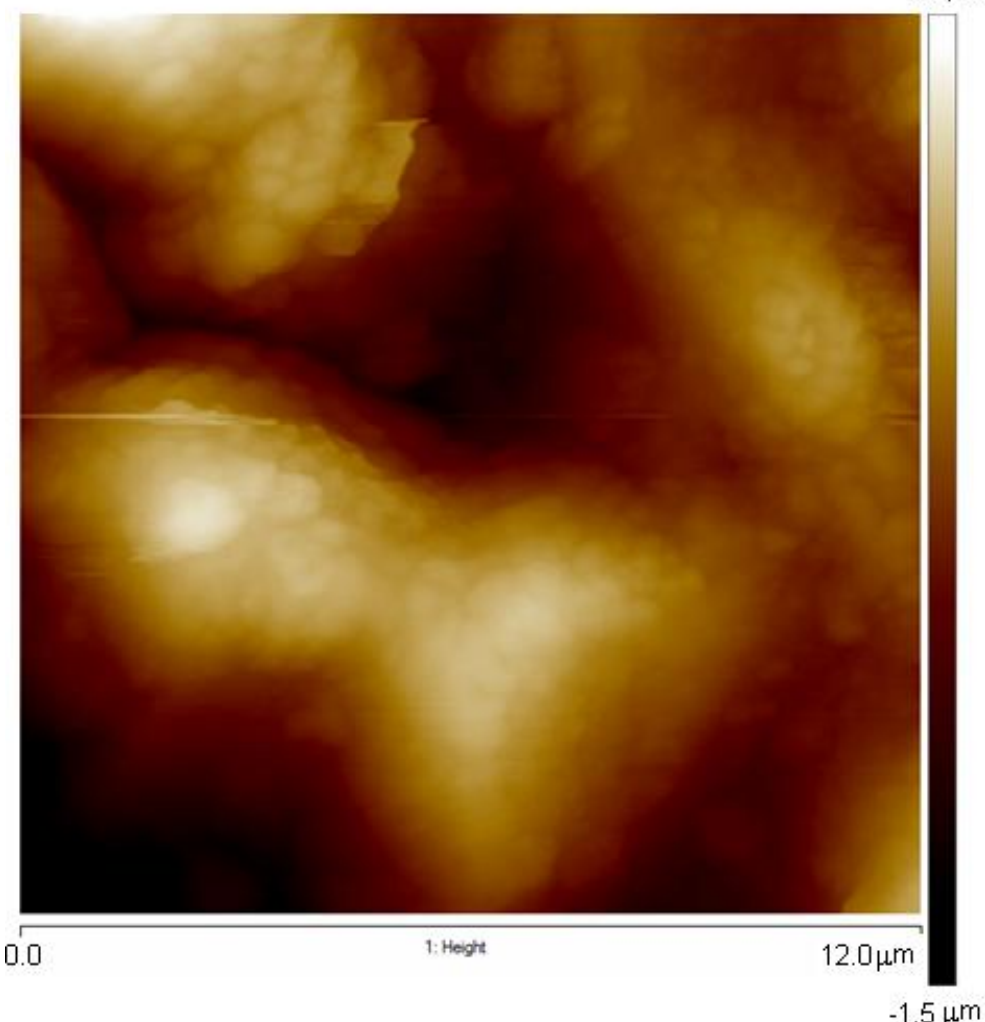

Figura 110. Imagem obtida por AFM (tapping mode) da topografia (alturas) da região analisada na superfície da amostra 3.

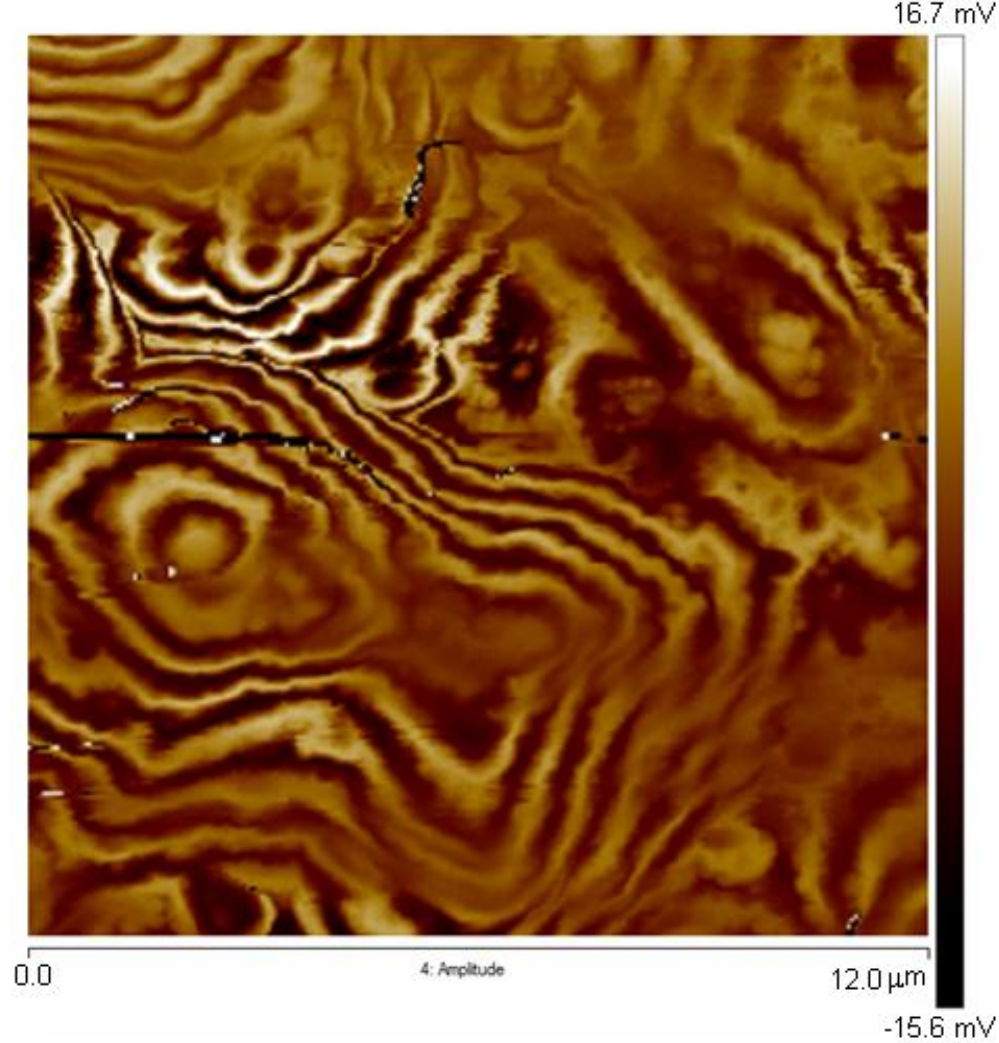

Figura 111. Imagem obtida por MFM da amplitude do campo magnético detectado na região selecionada na superfície da amostra 3. 


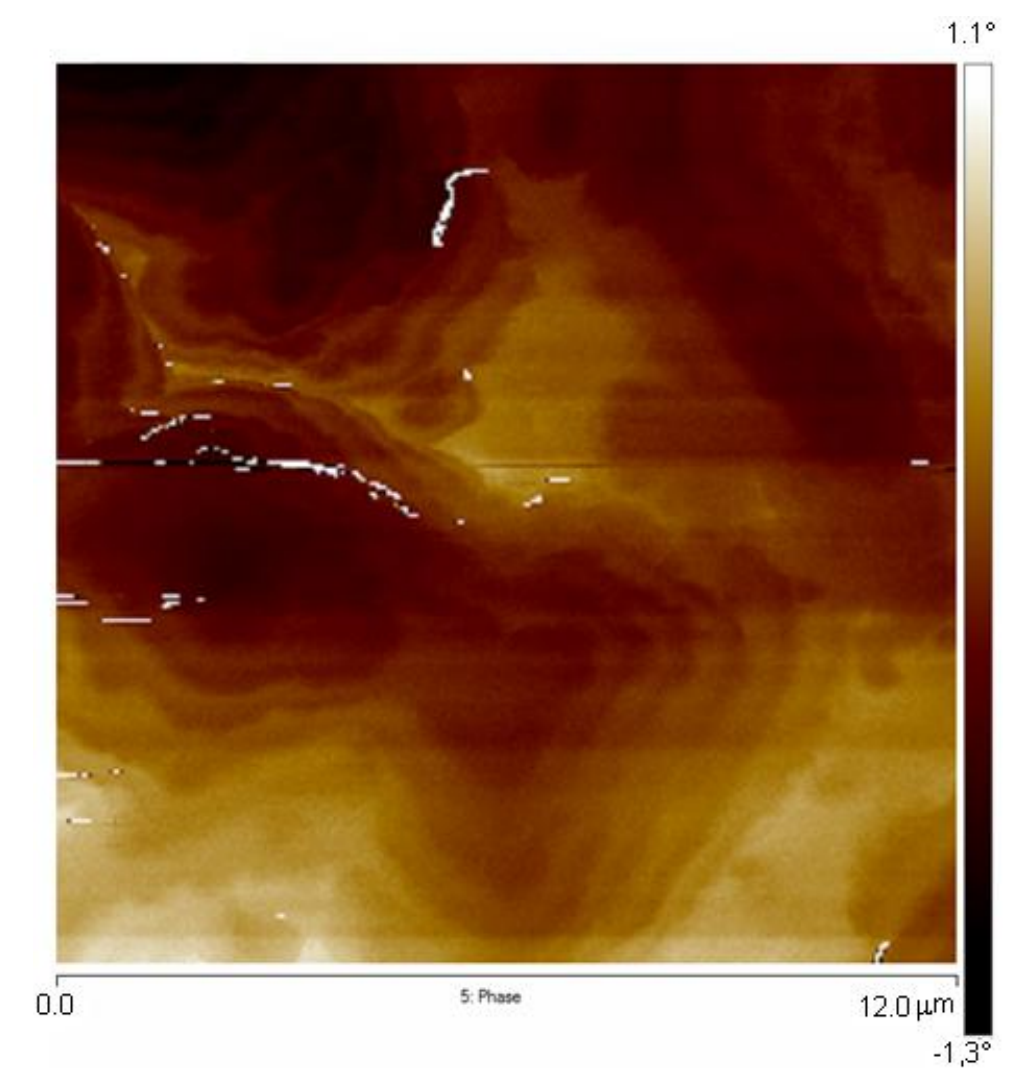

Figura 112. Imagem da diferença de fases detectada na superfície da amostra 3.

Nas Figuras 113 a 115 estão apresentados os resultados qualitativos obtidos pela técnica de MFM para as condições de texturização utilizadas para a amostra 4, que recebeu tratamento a laser com frequência de pulso $f=350 \mathrm{kHz}$. 


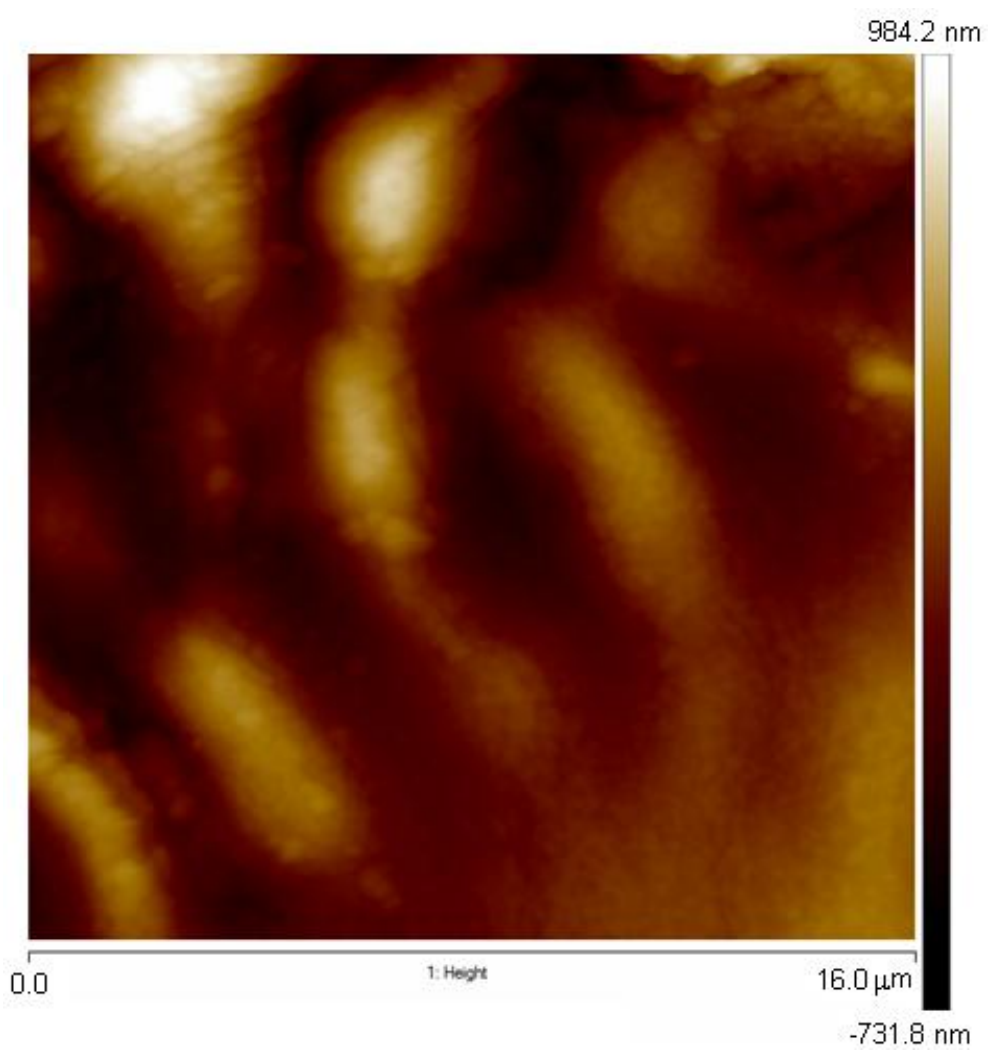

Figura 113. Imagem obtida por AFM (tapping mode) da topografia (alturas) da região analisada na superfície da amostra 4.

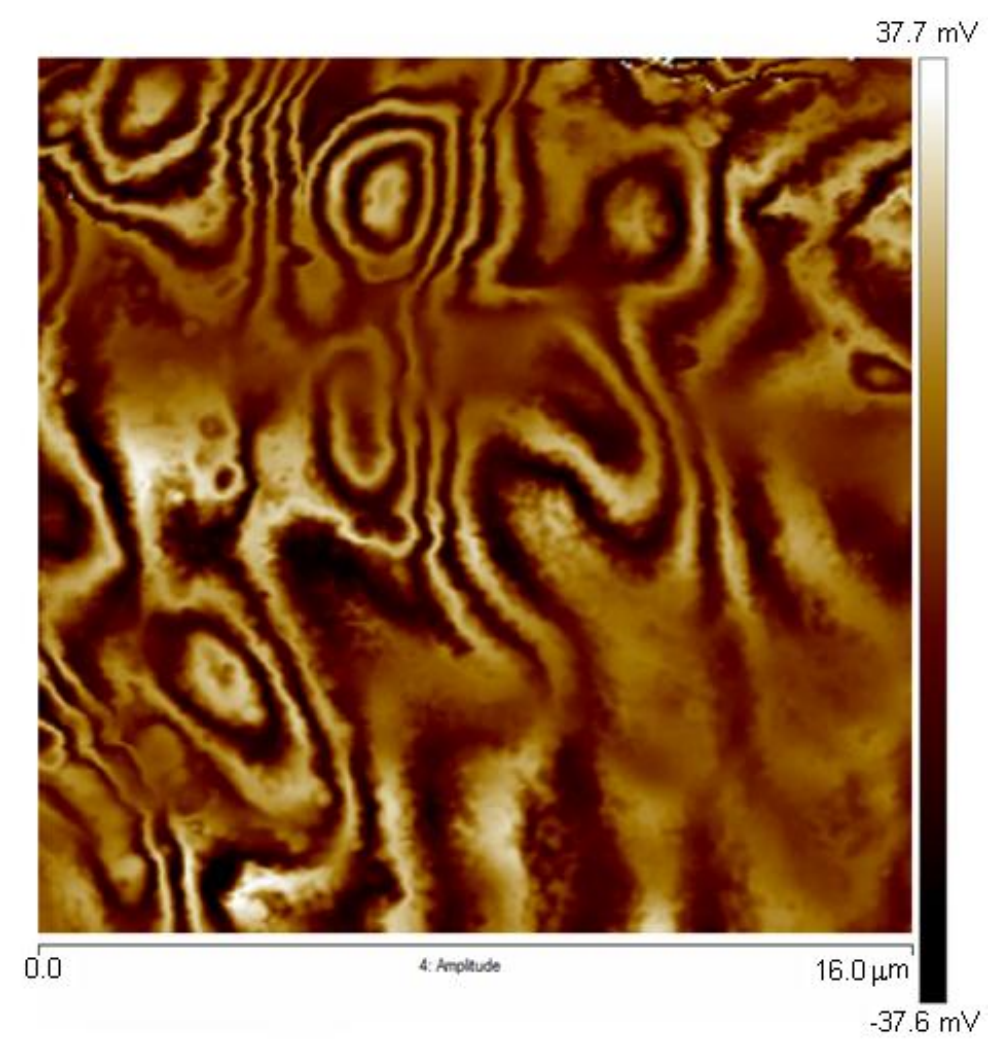

Figura 114. Imagem obtida por MFM da amplitude do campo magnético detectado na região selecionada na superfície da amostra 4. 


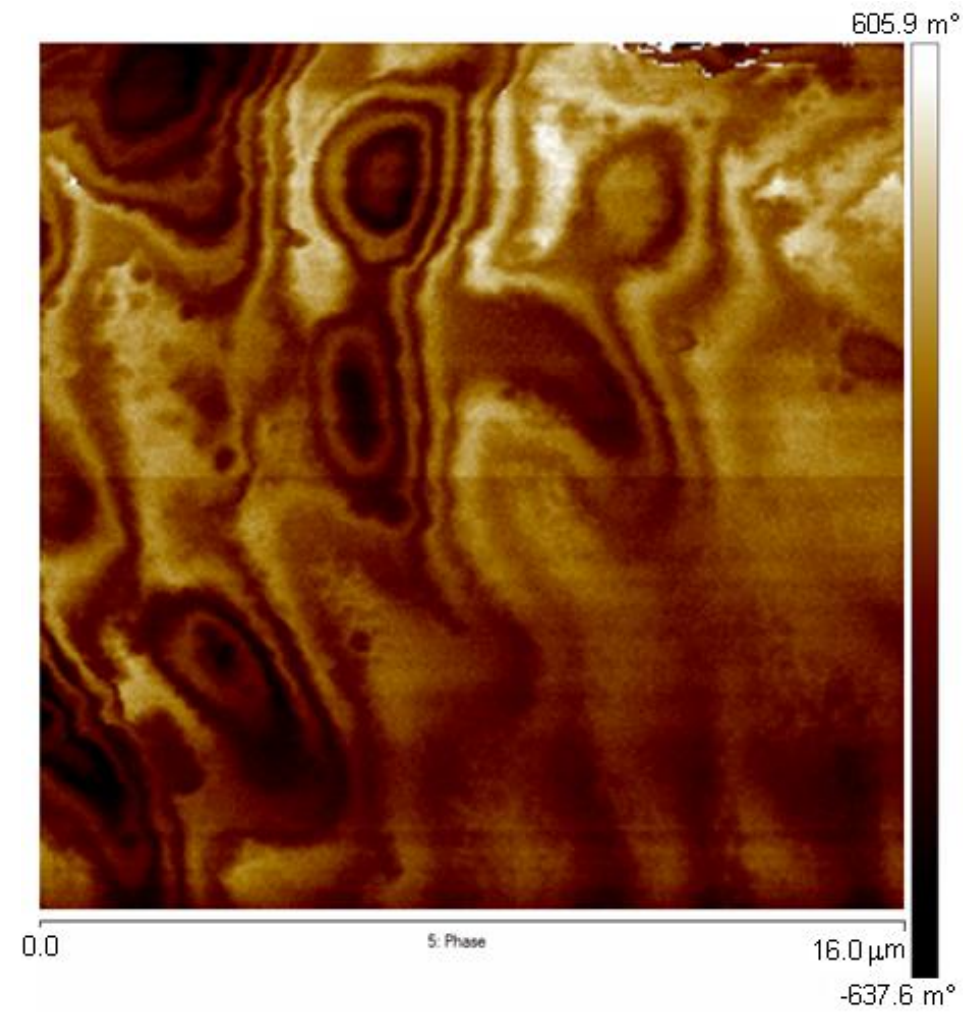

Figura 115. Imagem da diferença de fases detectada na superfície da amostra 4.

A técnica de microscopia de força magnética (MFM) aplicada à análise de aços inoxidáveis exibe particularidades em relação às demais técnicas existentes, uma delas é a altíssima resolução. Pesquisadores [114] a utilizaram para mapear a distribuição das fases: ferrita $(\delta)$, ferromagnética e, austenita $(\gamma)$, paramagnética, em aços inoxidáveis dúplex. Conforme a pesquisa, esta técnica pode ser empregada para se detectar a presença de ferrita após se observar sinais magnéticos, mesmo que de baixa amplitude, em regiões de austenita.

As medições de campo magnético pela técnica de MFM se dão pela presença e detecção de sinais deste campo orientados na direção $z$, isto é, perpendicular ao plano da amostra. Isto ocorreu naturalmente em todas as amostras texturizadas, independentemente da variação do parâmetro frequência de pulso do feixe laser.

As avaliações de campo magnético por MFM são de caráter qualitativo. Notam-se imagens qualitativamente distintas nos sinais de amplitude e de diferença de fase. Este fato comprova os resultados obtidos pela técnica de medições de sinais magnéticos por balança de precisão apresentados na seção anterior. A análise das imagens obtidas por MFM sugere que a variação do 
parâmetro de texturização a laser, acarreta em variação de intensidades e distribuição de sinais de campo magnético nas superfícies deste biomaterial.

A presença de campo magnético não é desejável em um biomaterial para dispositivo médico implantável no campo ortopédico, por isso as normas exigirem a fabricação com ligas metálicas isentas de fases ferromagnéticas.

A hipótese sugerida para justificar o surgimento de fase ferromagnética induzida pelo tratamento por feixe laser é a de que o aço inoxidável ABNT NBR ISO 5832-1 pode se solidificar formando austenita $(\gamma)$ e ferrita $(\delta)$ e, apesar dos tempos envolvidos na solidificação serem bem diminutos. Em se tratando de fenômenos de superfície, que ocorrem em dimensões nanométricas, são tempos suficientes para a ocorrência destas transformações de fases. O aumento de teores de cromo, estabilizante da ferrita $\delta$, que é magnética, associado ao campo magnético obtido nas superfícies comprova esta hipótese. 


\section{CONCLUSÕES}

A variação da frequência dos pulsos do feixe laser acarretou em mudanças na topografia do biomaterial utilizado; sendo o aumento da frequência diretamente ligado ao aumento de rugosidade e de microdureza nas superfícies texturizadas.

A microestrutura e composição química das superfícies sofreram alterações em decorrência do aumento da frequência de pulso. Notou-se aumento nos teores de cromo e manganês e diminuição nos teores de ferro e níquel.

A migração de $\mathrm{Cr}$ da matriz e a formação de regiões na interface de grande diferença composicional e, portanto, de formação de micro-pilhas, além de aumento de rugosidade, favorecem o ataque corrosivo na interface laser e matriz.

A abordagem de Mott-Schottky mostrou-se sensível para identificar o efeito do tipo de tratamento superficial, de marcação e texturização, de acordo com o aumento da frequência, nas propriedades eletrônicas do filme passivo.

A técnica SVET comprovou que as regiões marcadas apresentam a possibilidade de formação de filme passivo em razão dos períodos de imersão. Entretanto, maiores densidades de correntes anódicas foram associadas às regiões marcadas a laser.

As propriedades biomecânicas não foram comprometidas, uma vez que os tratamentos a laser não influenciaram a resistência à fadiga deste biomaterial, sugerindo que não foram geradas tensões de magnitude tal que abreviassem a vida em fadiga deste biomaterial, tampouco se pôde relacionar a região de fratura por tração com as marcações a laser.

O volume de desgaste diminuiu em função do aumento da microdureza produzido pela elevação nos valores de frequência do pulso nas texturizações.

Os tratamentos a laser de marcação e texturização afetaram a susceptibilidade magnética das superfícies, sendo maior para as amostras texturizadas quando comparadas às demais condições de acabamento superficial, o que é indesejável para um biomaterial.

A técnica de microscopia de força magnética possibilitou a detecção de campo magnético de diferentes intensidades em razão do aumento de frequência de pulso de laser para as amostras texturizadas, efeito que foi associado ao aumento de cromo nas superfícies. 
Mesmo após os ensaios realizados por imersão, tais como SVET, monitoramento de potencial de corrosão em circuito aberto, espectroscopia de impedância eletroquímica e citotoxicidade, as amostras com marcações e com texturizações mantiveram as suas características visuais, ou seja, a nitidez dos tratamentos a laser foi assegurada. Este efeito foi diminuído com a polarização das amostras.

Os ensaios de citotoxicidade com incubação prolongada revelaram que as marcações e texturizações a laser, nas condições utilizadas, não diminuíram a viabilidade celular, portanto podem ser utilizadas sem prejuízo da biocompatibilidade deste biomaterial.

As condições de tratamento por feixe laser de fibra óptica devem ser amplamente analisadas, pois podem apresentar resultados antagônicos de acordo com os aspectos avaliados. Do ponto de vista biomecânico e de biocompatibilidade, nas condições utilizadas, os resultados foram satisfatórios. Entretanto, sob o aspecto eletroquímico, foram insatisfatórios. 


\section{SUGESTÕES PARA TRABALHOS FUTUROS}

1. Análise dos filmes passivos formados sobre o material empregando-se as técnicas de AES.

2. Realizar ensaios de fadiga associado ao monitoramento da corrosão em amostras cilíndricas.

3. Realizar ensaios de fadiga em regime de flexo-compressão e flexo-torção.

4. Analisar amostras texturizadas a laser por EBSD.

5. Realizar ensaios de tribocorrosão. 


\section{APÊNDICE}

1) Valores de contagens de elementos químicos obtidos por XPS para cada amostra avaliada.
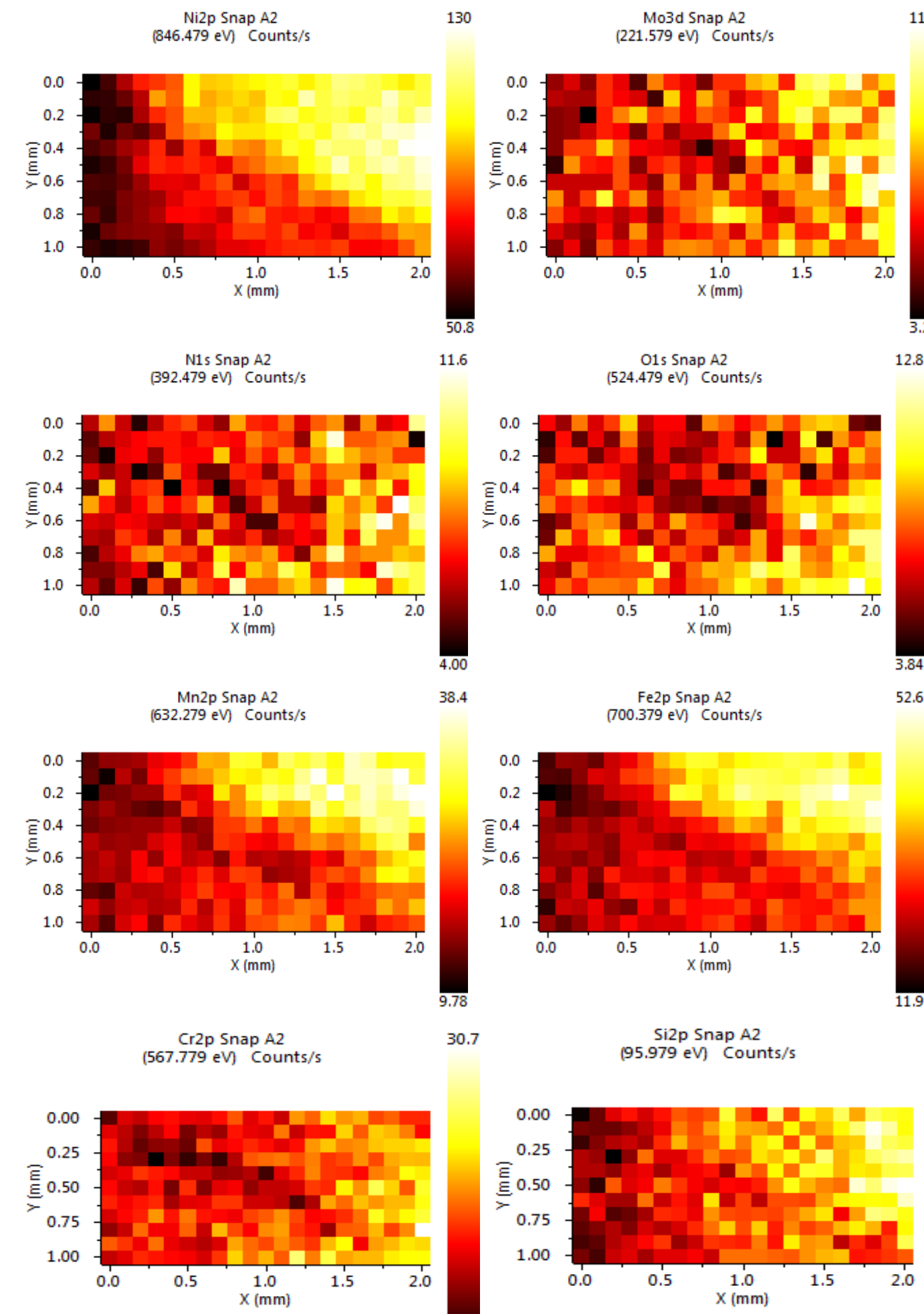

30.7

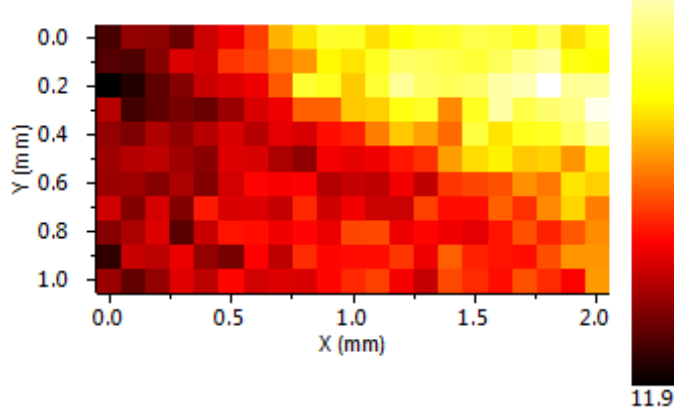

30.7
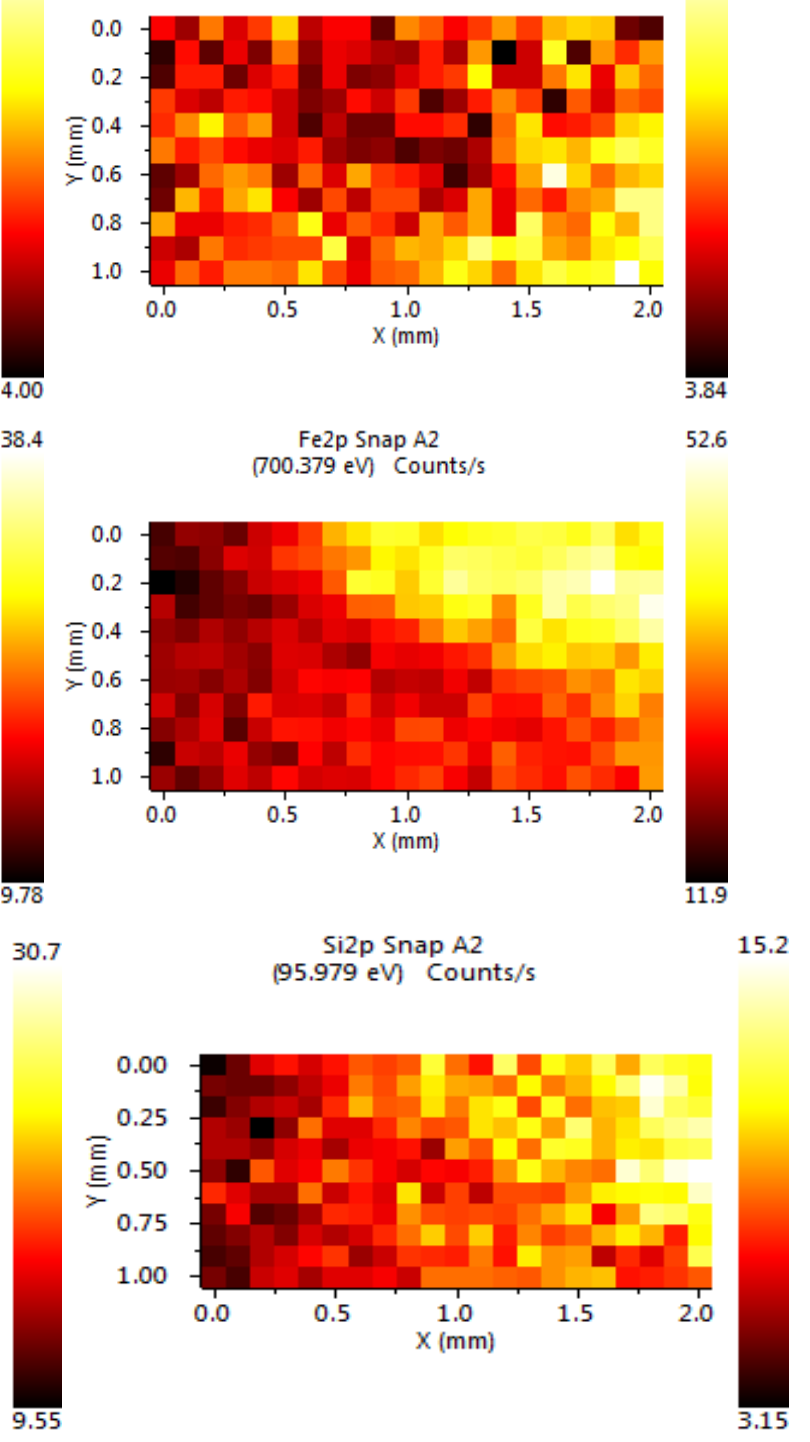

Figura 1. Distribuição de elementos químicos presentes em área de $2,0 \mathrm{~mm}^{2}$ do filme passivo formado na superfície da amostra 2, obtido por XPS. 


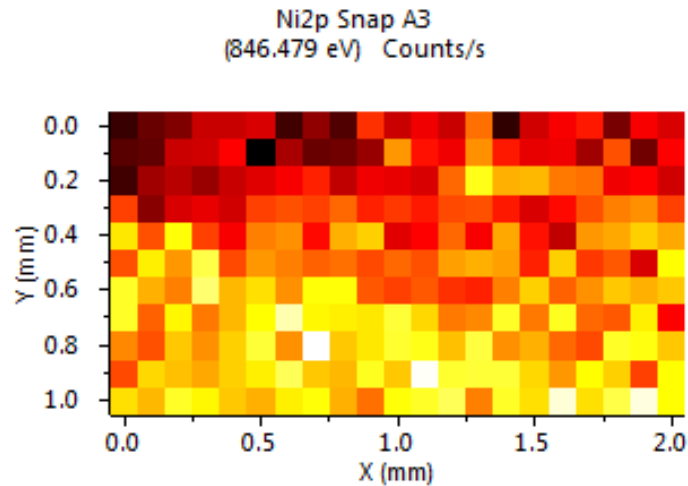

N1s Snap A3 (392.479 eV) Counts/s

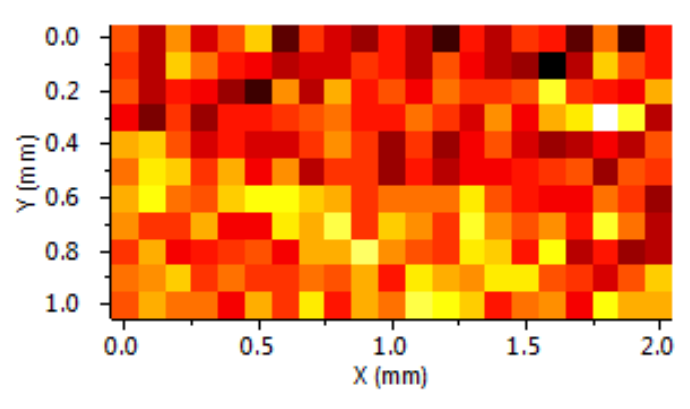

Mn2p Snap A3 $(632.279 \mathrm{eV})$ Counts/s

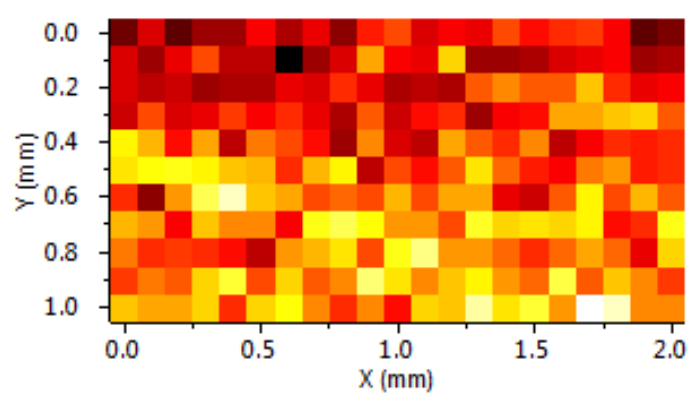

Cr2p Snap A3 (567.779 eV) Counts/s

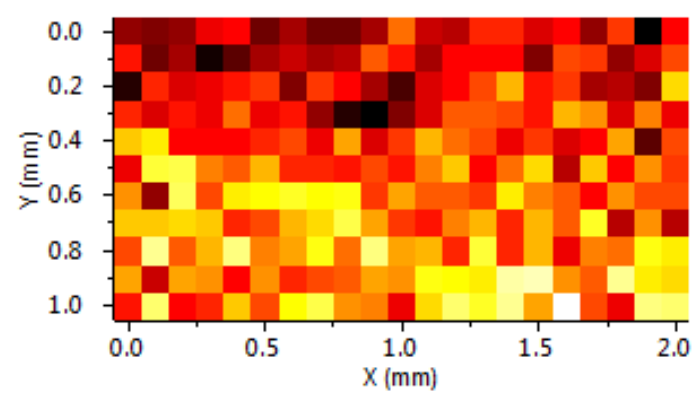

29.6

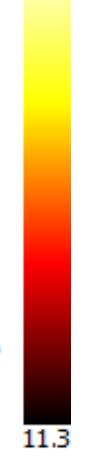

4.90

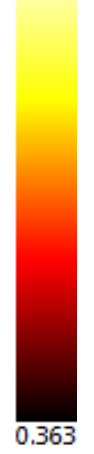

11.3

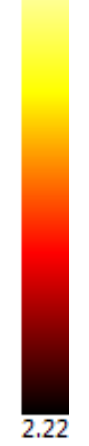

10.1

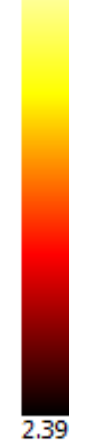

Mo3d Snap A3 (221.579 eV) Counts/s

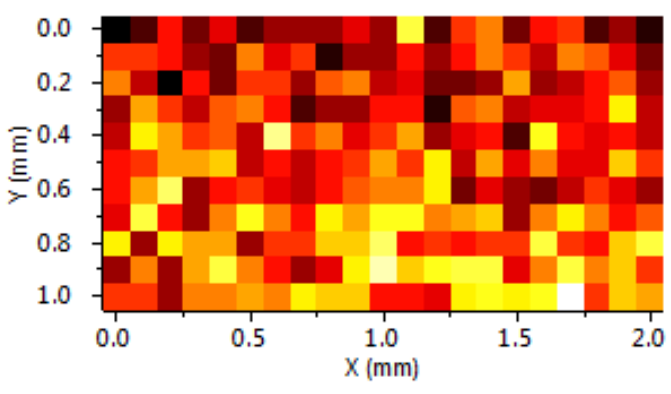

O1s Snap A3 (524.479 eV) Counts/s

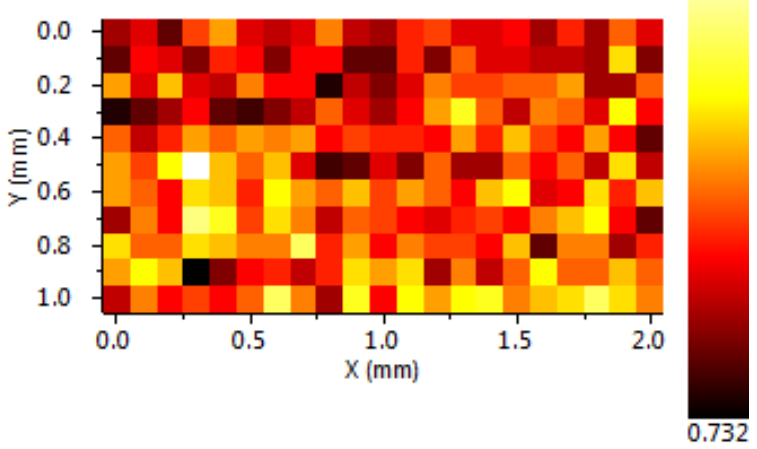

Fe2p Snap A3 (700.379 eV) Counts/s

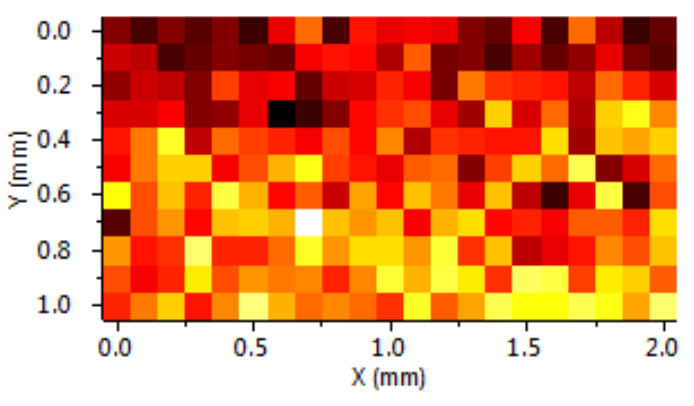

Si2p Snap A3 (105.958 eV) Counts/s

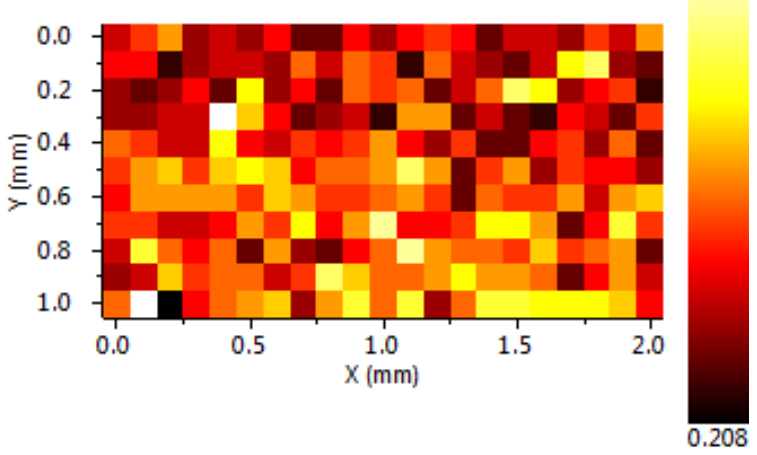

Figura 2. Distribuição de elementos químicos presentes em área de $2,0 \mathrm{~mm}^{2}$ do filme passivo formado na superfície da amostra 3, obtido por XPS. 
$\mathrm{Ni} 2 \mathrm{p}$ Snap A4

(846.479 eV) Counts/s

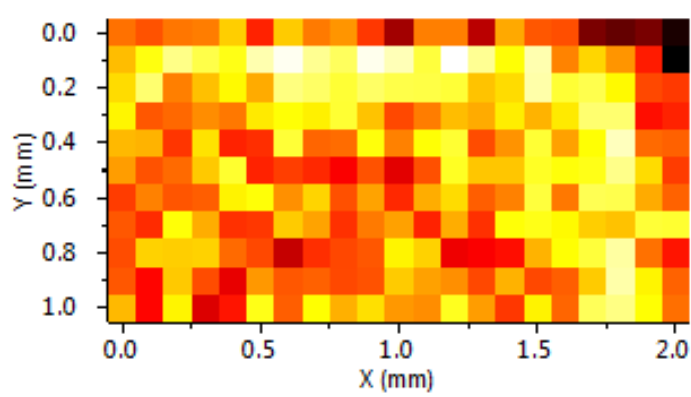

N1s Snap A4 (392.479 eV) Counts/s

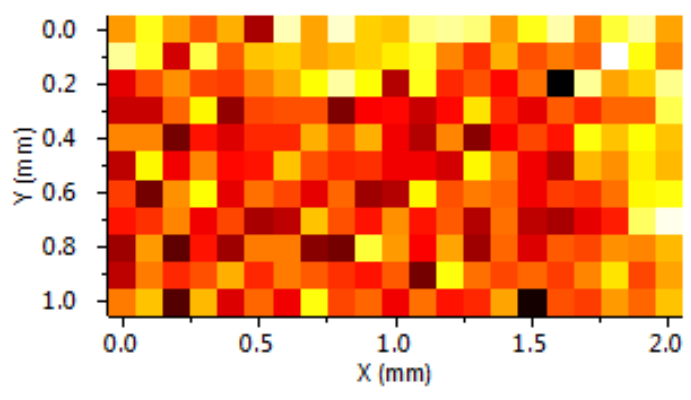

Mn2p Snap A4 (632.279 eV) Counts/s

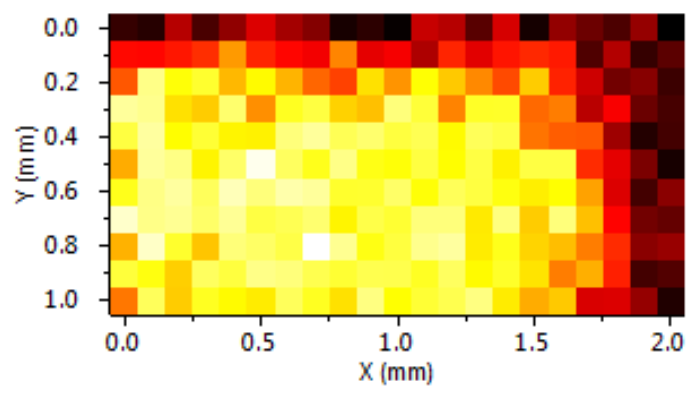

$\mathrm{Cr} 2 \mathrm{p}$ Snap A4 (567.779 eV) Counts/s

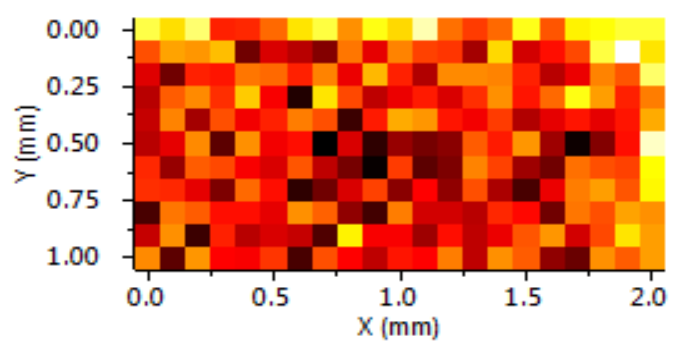

226

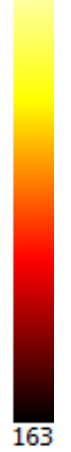

30.7

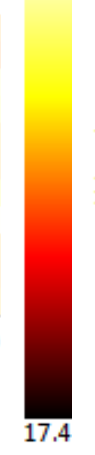

105

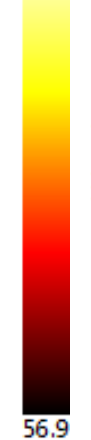

69.6

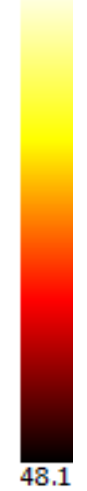

Mo3d Snap A4 (221.579 eV) Counts/s

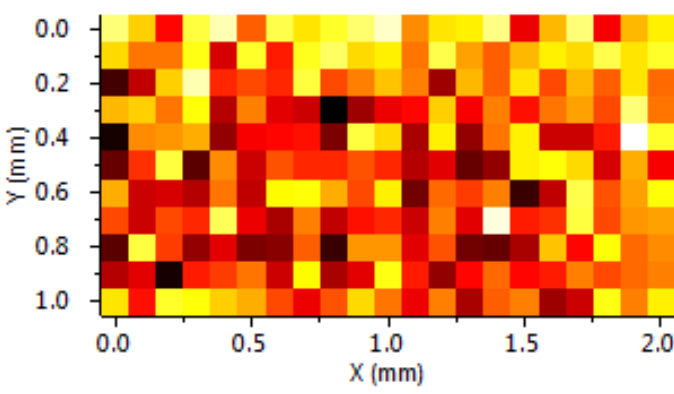

O1s Snap A4

(524.479 eV) Counts/s

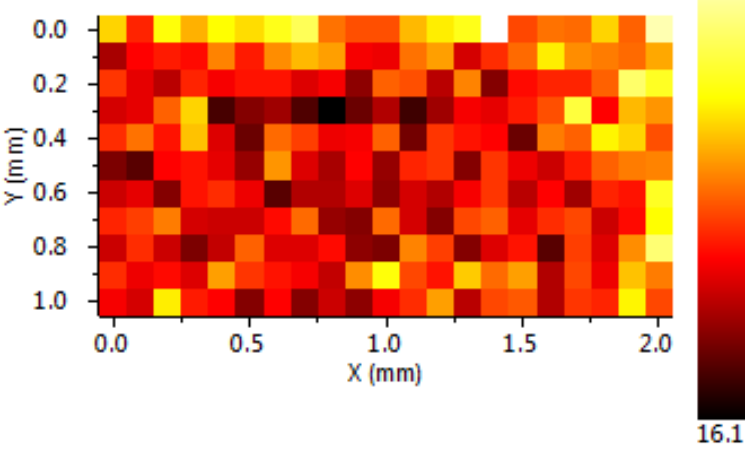

Fe2p Snap A4 (700.379 eV) Counts/s

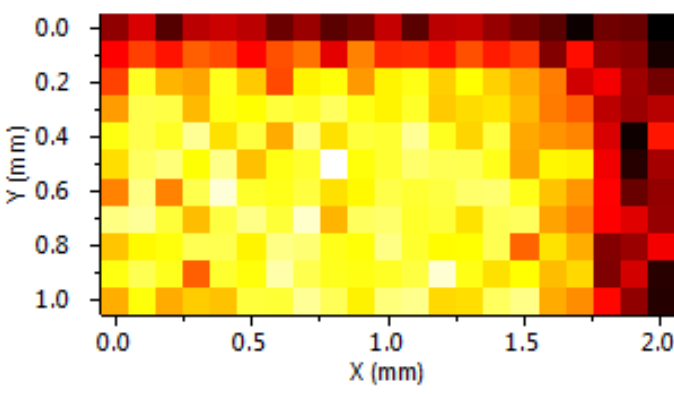

Si2p Snap A4 (95.979 eV) Counts/s

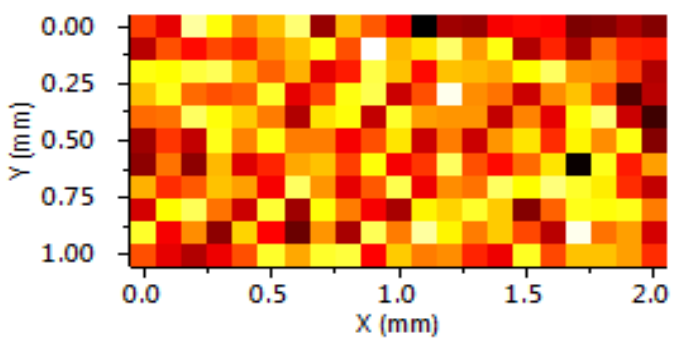

Figura 3. Distribuição de elementos químicos presentes em área de $2,0 \mathrm{~mm}^{2}$ do filme passivo formado na superfície da amostra 4, obtido por XPS. 


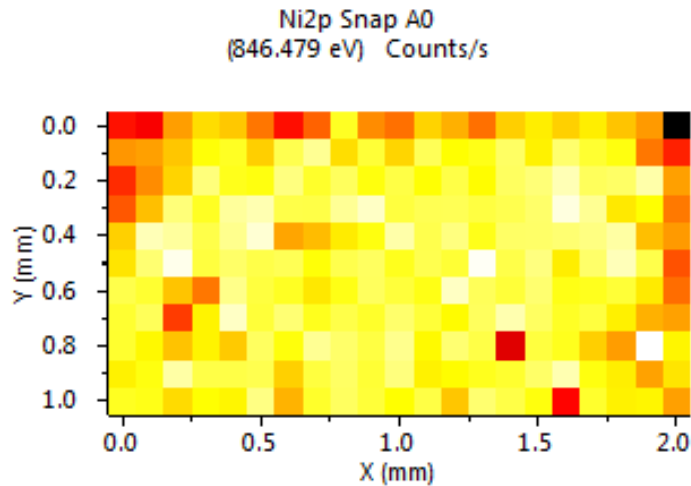

N1s Snap A0 (392.479 eV) Counts/s

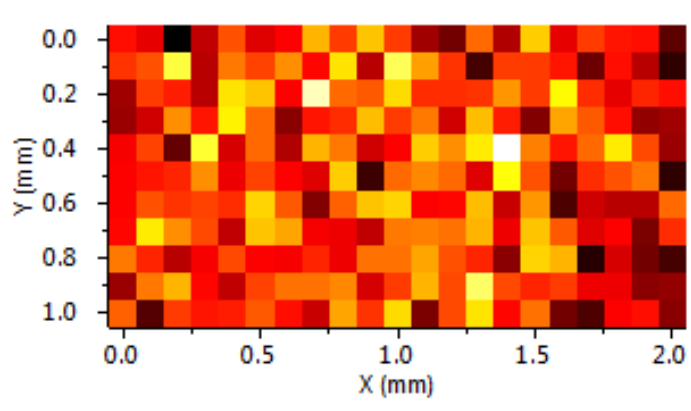

$\mathrm{Mn} 2 \mathrm{p}$ Snap AO $(632.279 \mathrm{eV})$ Counts/s

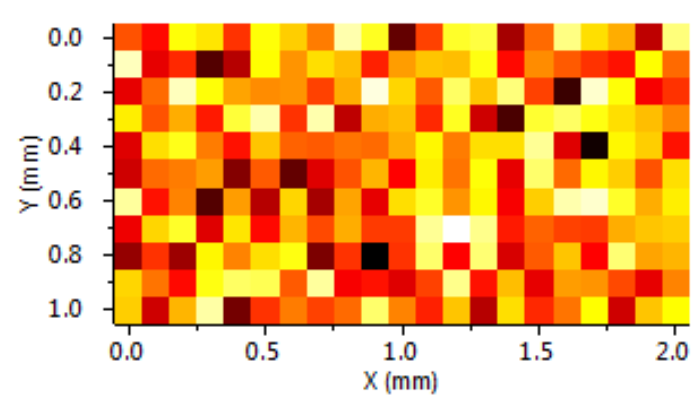

323

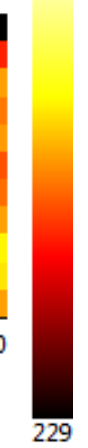

52.0

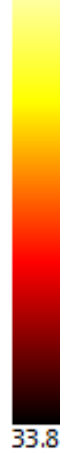

76.1

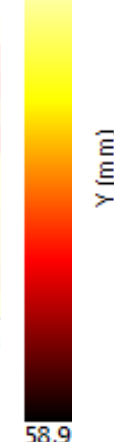

Mo3d Snap AO (221.579 eV) Counts/s

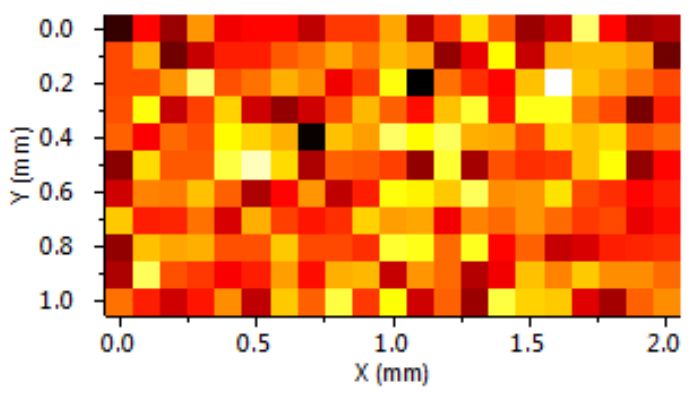

O1s Snap A0 (524.479 ev) Counts/s

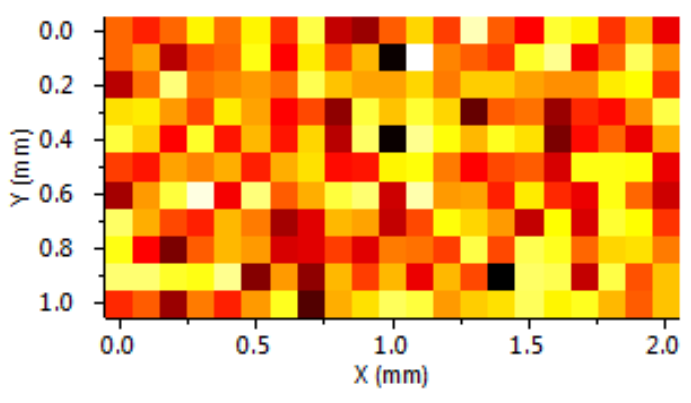

Fe2p Snap A0 (700.379 eV) Counts/s

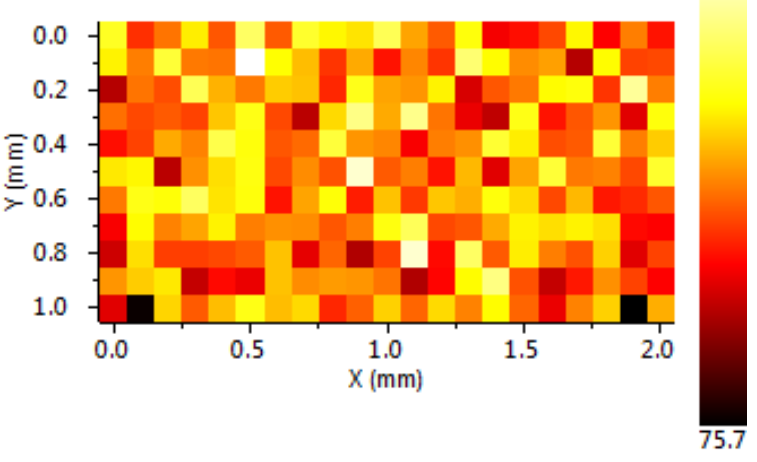

65.8

Si2p Snap AO (95.979 eV) Counts/s 
2) Valores de contagens de elementos químicos obtidos por XPS para cada amostra avaliada em apresentados em razão do elemento químico.
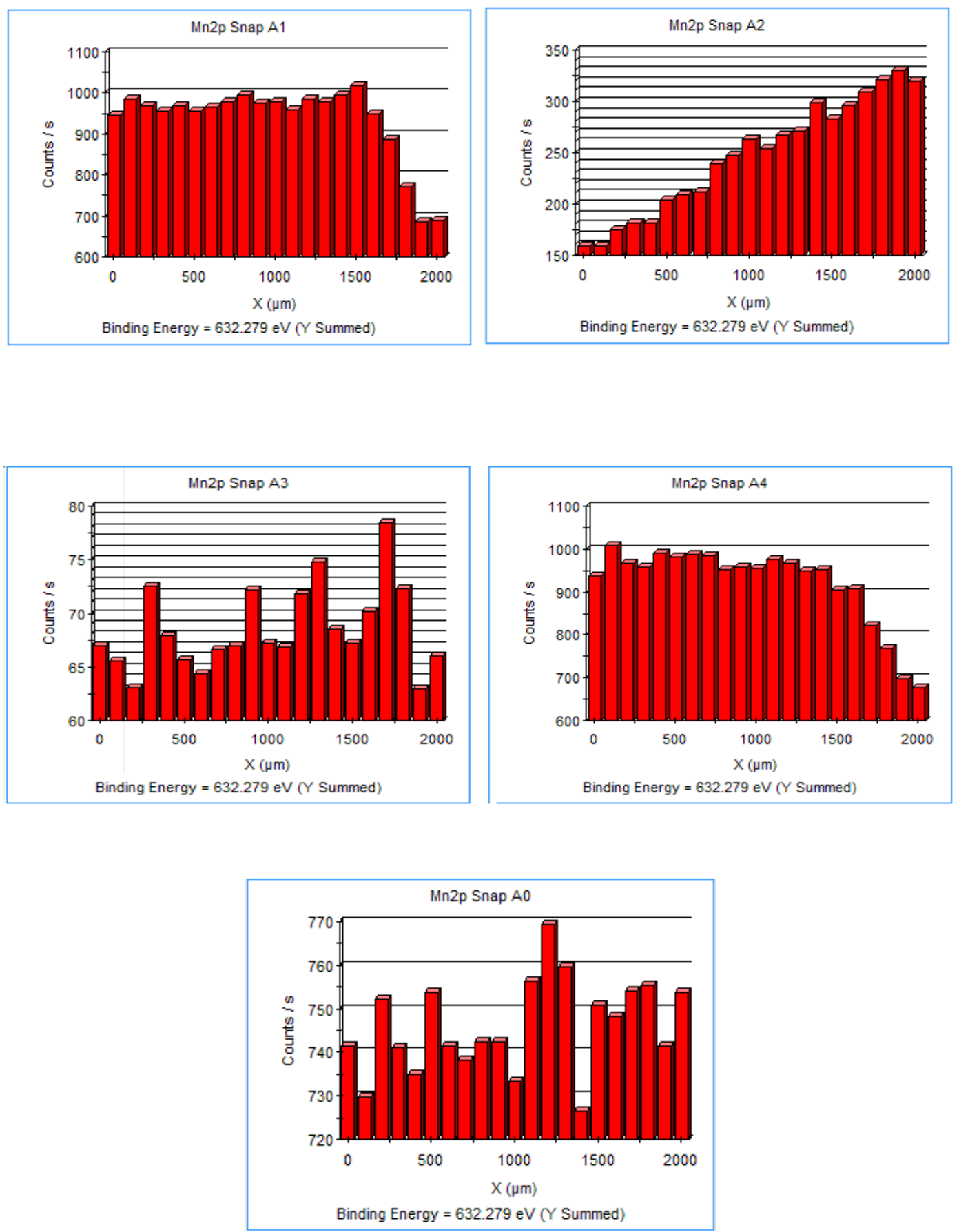

Figura 5. Contagens do elemento $\mathrm{Mn}$ presente em área de 2,0 $\mathrm{mm}^{2}$ do filme passivo formado na superfície das amostras 1, 2, 3, 4 e padrão, obtido por XPS. No eixo x estão os valores das distâncias das amostras que foram avaliadas. 

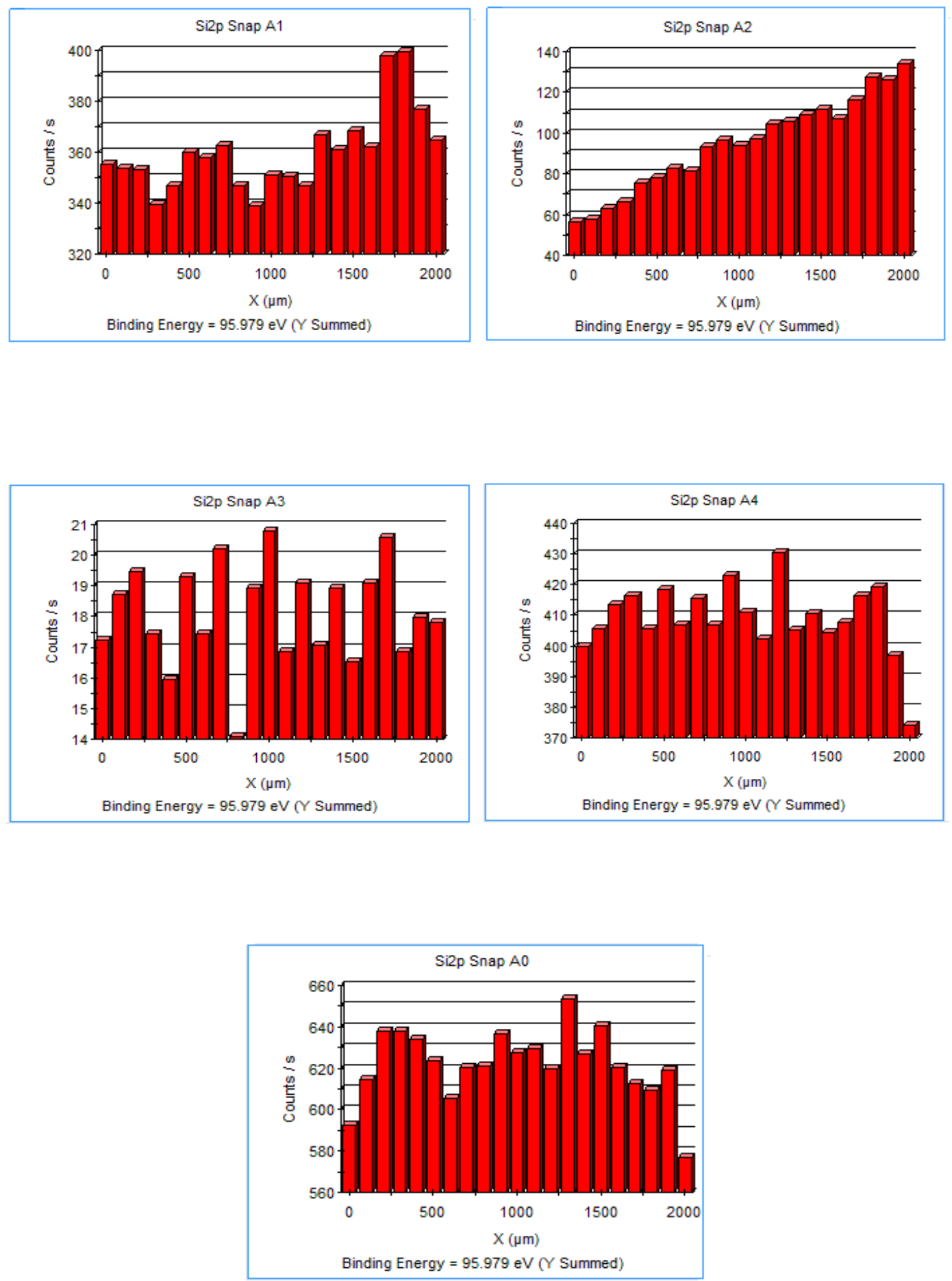

Figura 6. Contagens do elemento Si presente em área de $2,0 \mathrm{~mm}^{2}$ do filme passivo formado na superfície das amostras 1, 2, 3, 4 e padrão, obtido por XPS. No eixo x estão os valores das distâncias das amostras que foram avaliadas. 

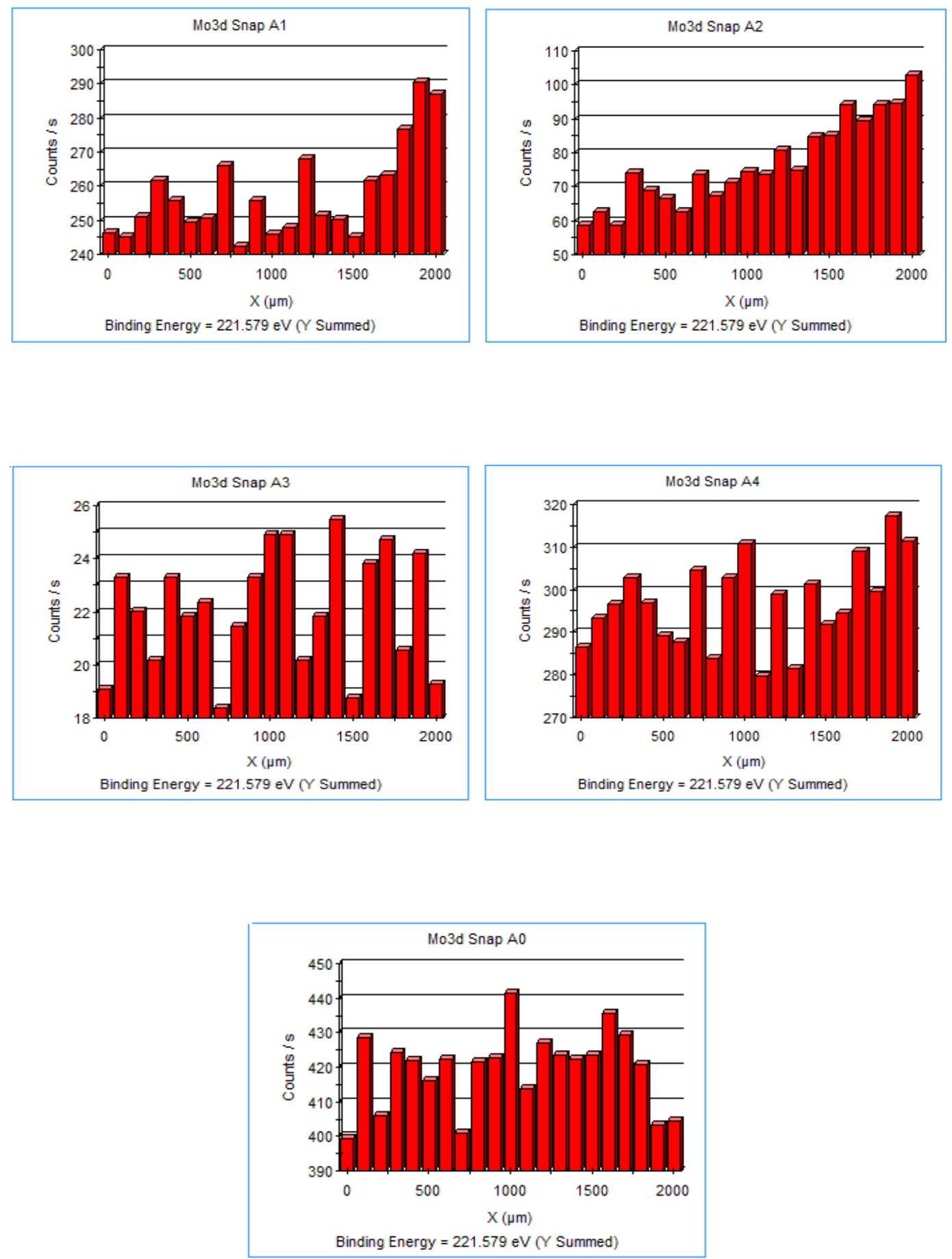

Figura 7. Contagens do elemento Mo presente em área de 2,0 $\mathrm{mm}^{2}$ do filme passivo formado na superfície das amostras 1, 2, 3, 4 e padrão, obtido por XPS. No eixo x estão os valores das distâncias das amostras que foram avaliadas. 

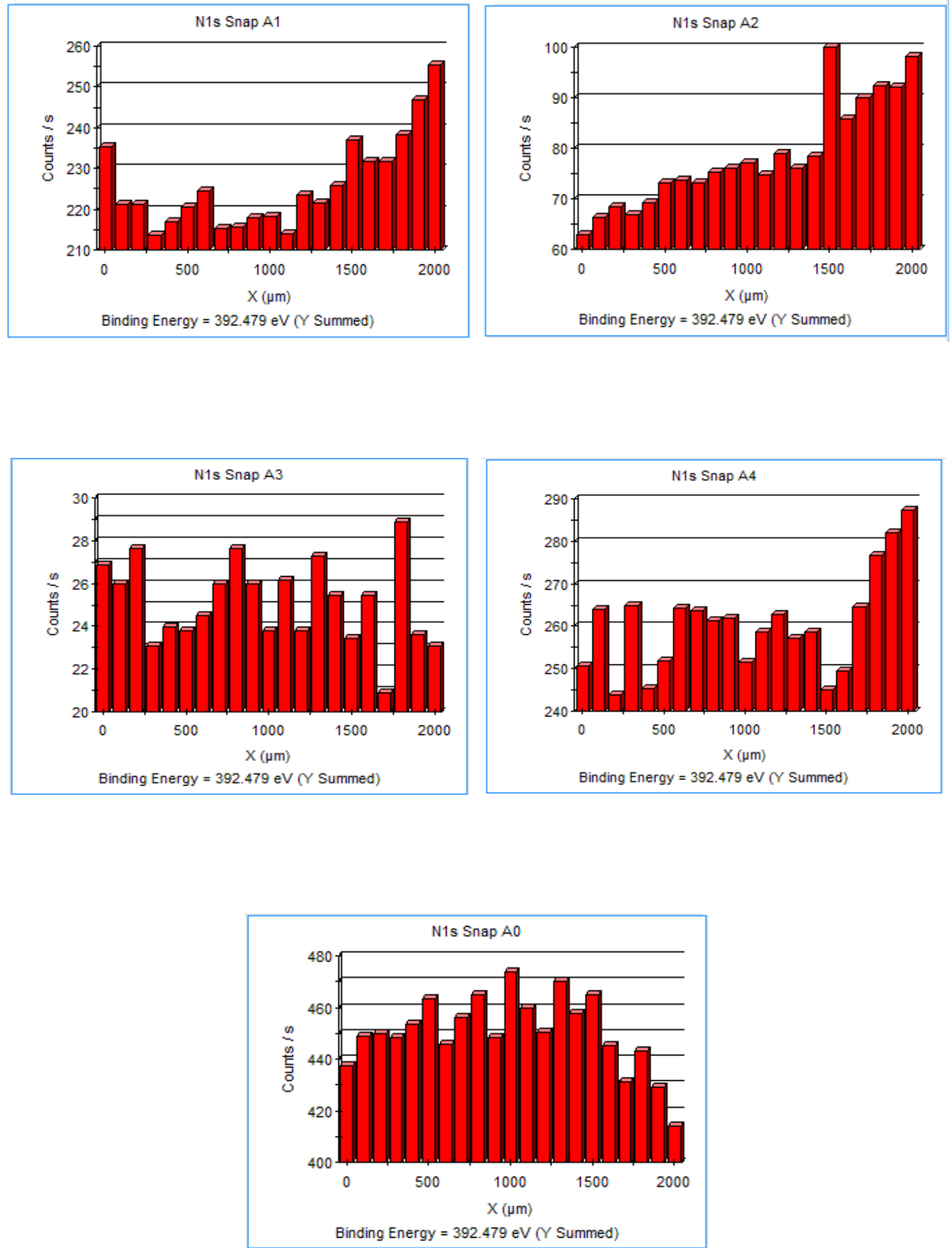

Figura 8. Contagens do elemento $\mathrm{N}$ presente em área de $2,0 \mathrm{~mm}^{2}$ do filme passivo formado na superfície das amostras 1, 2, 3, 4 e padrão, obtido por XPS. No eixo x estão os valores das distâncias das amostras que foram avaliadas. 

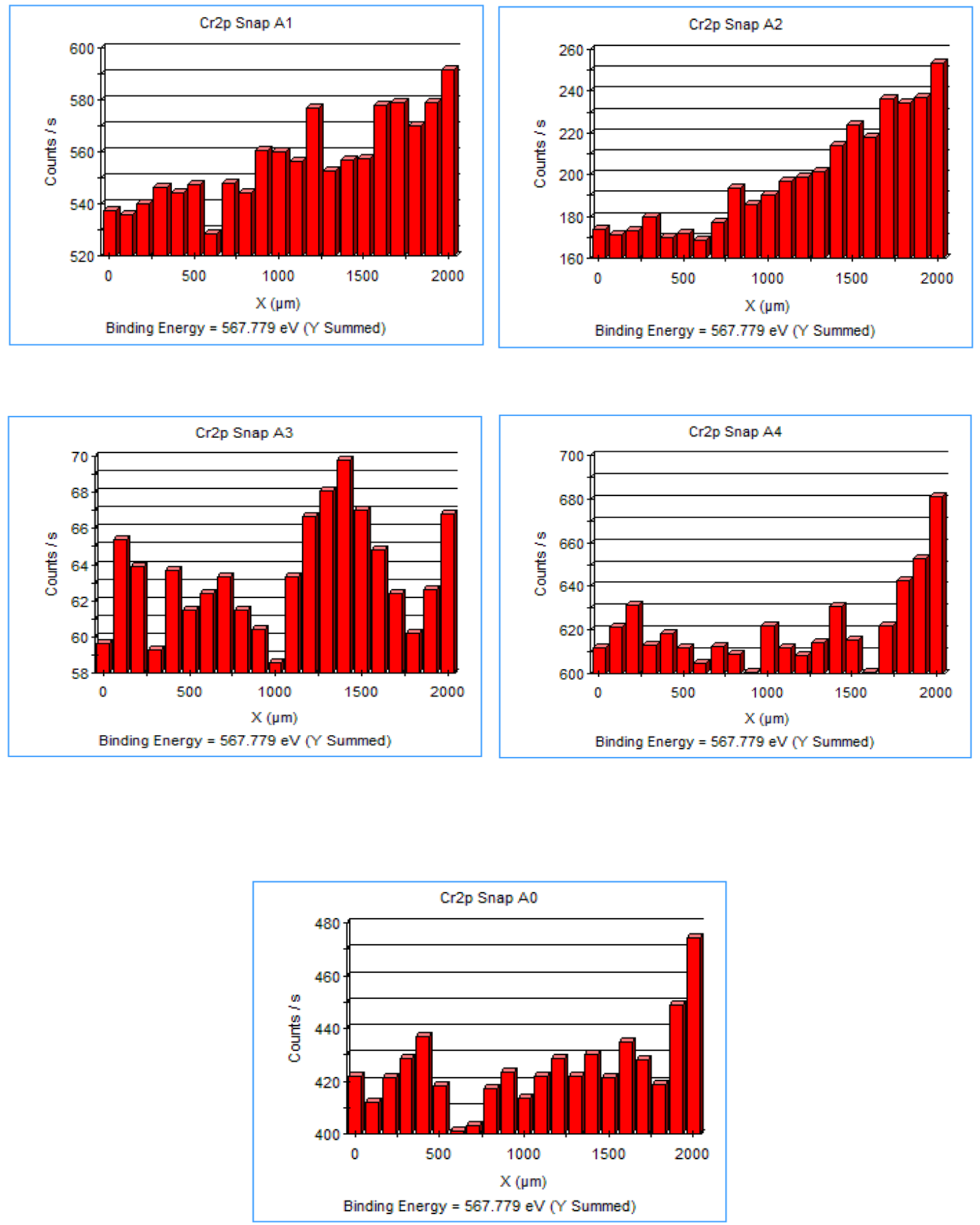

Figura 9. Contagens do elemento $\mathrm{Cr}$ presente em área de $2,0 \mathrm{~mm}^{2}$ do filme passivo formado na superfície das amostras 1, 2, 3, 4 e padrão, obtido por XPS. No eixo x estão os valores das distâncias das amostras que foram avaliadas. 

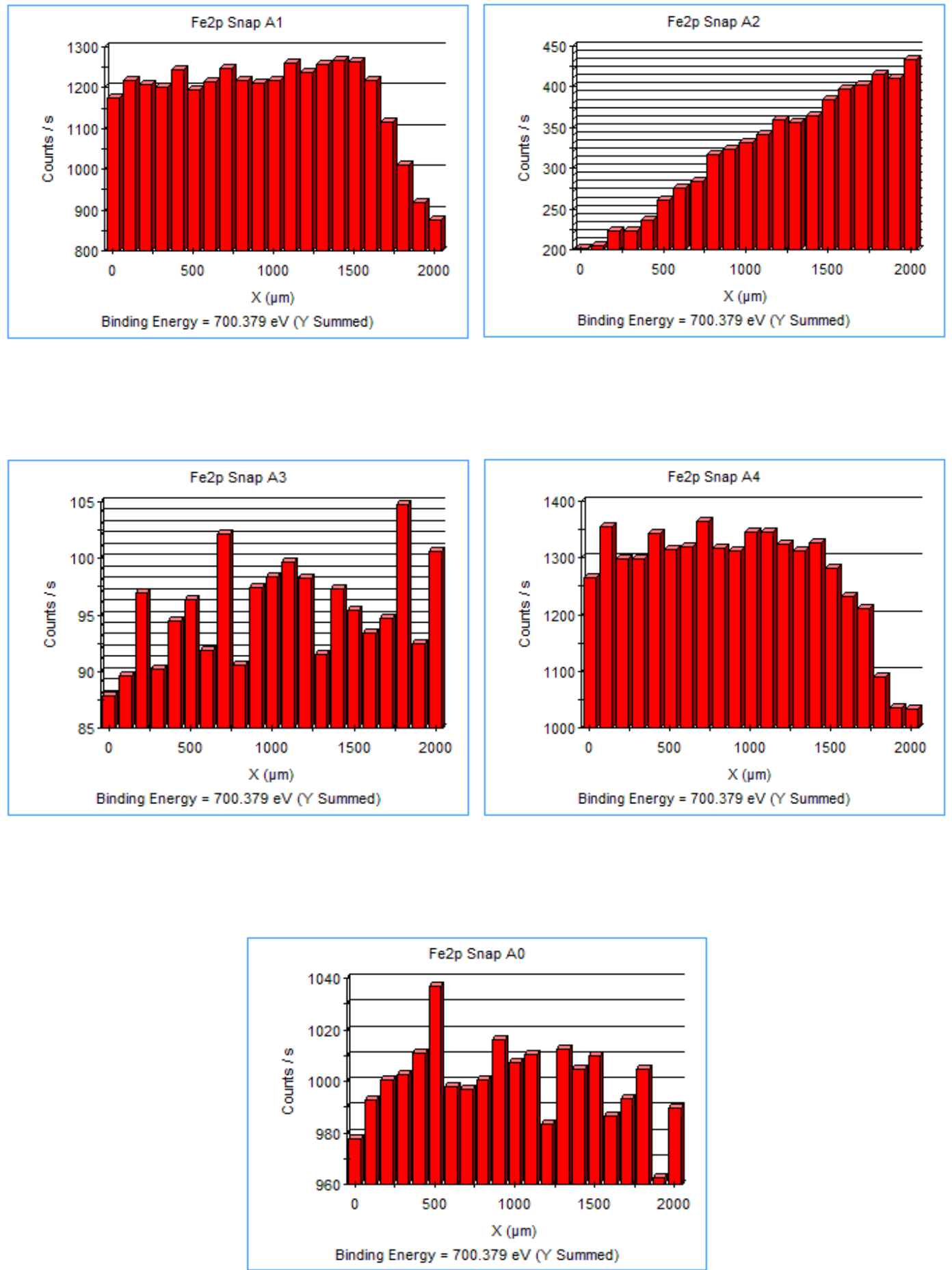

Figura 10. Contagens do elemento Fe presente em área de $2,0 \mathrm{~mm}^{2}$ do filme passivo formado na superfície das amostras 1, 2, 3, 4 e padrão, obtido por XPS. No eixo x estão os valores das distâncias das amostras que foram avaliadas. 

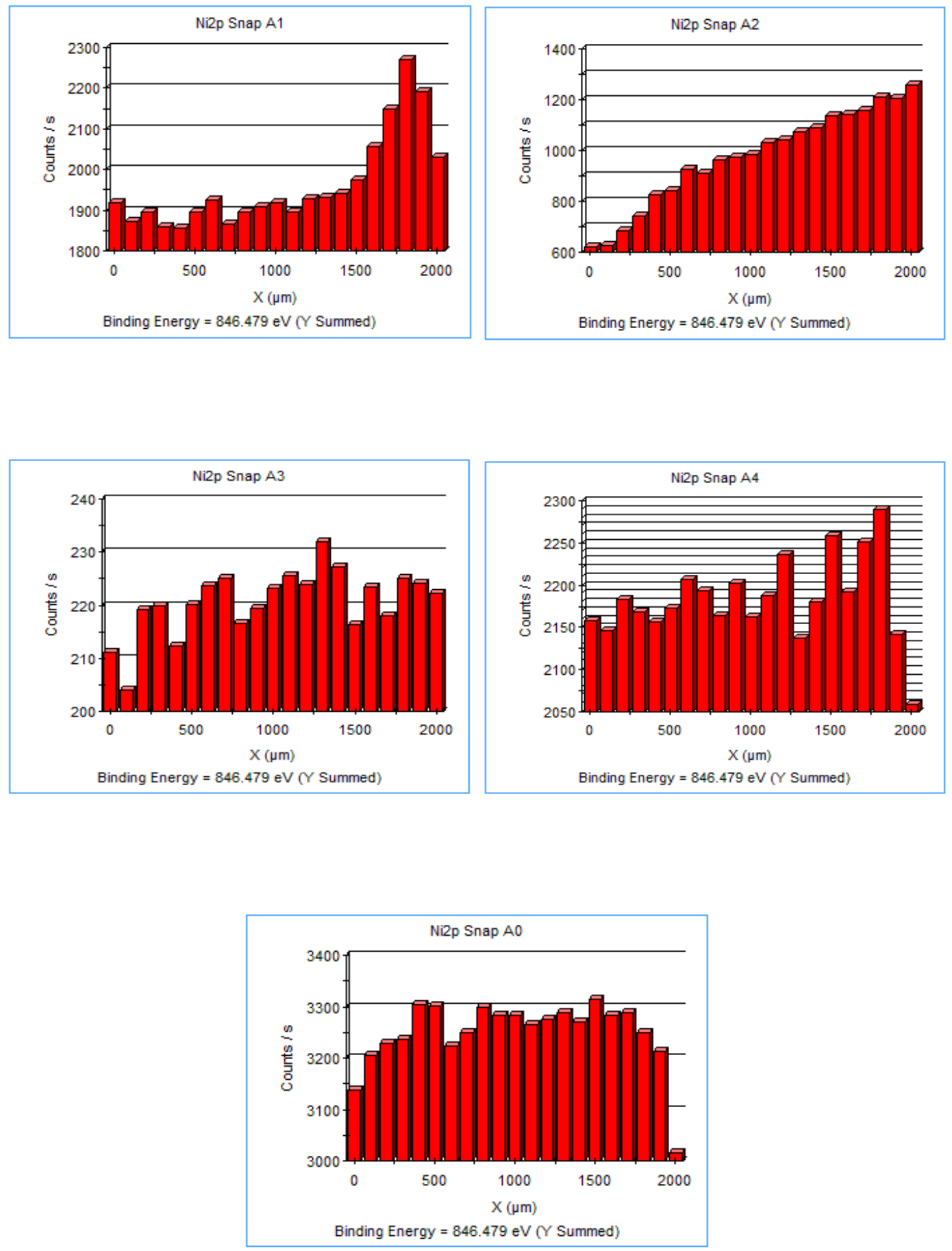

Figura 11. Contagens do elemento Ni presente em área de 2,0 $\mathrm{mm}^{2}$ do filme passivo formado na superfície das amostras 1, 2, 3, 4 e padrão, obtido por XPS. No eixo x estão os valores das distâncias das amostras que foram avaliadas. 

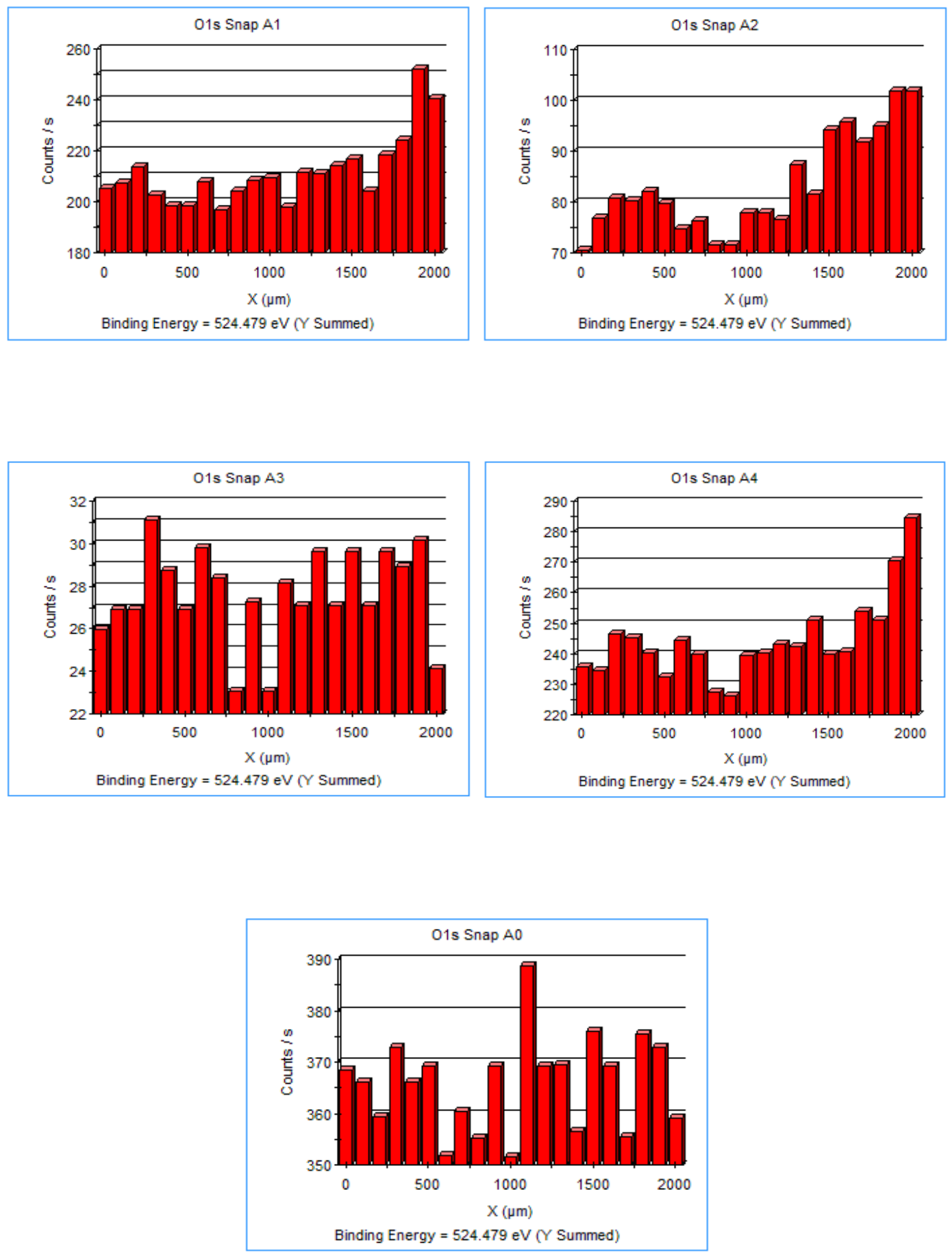

Figura 12. Contagens do elemento $O$ presente em área de $2,0 \mathrm{~mm}^{2}$ do filme passivo formado na superfície das amostras 1, 2, 3, 4 e padrão, obtido por XPS. No eixo x estão os valores das distâncias das amostras que foram avaliadas. 
3) Valores obtidos para os ajustes de CEE's.

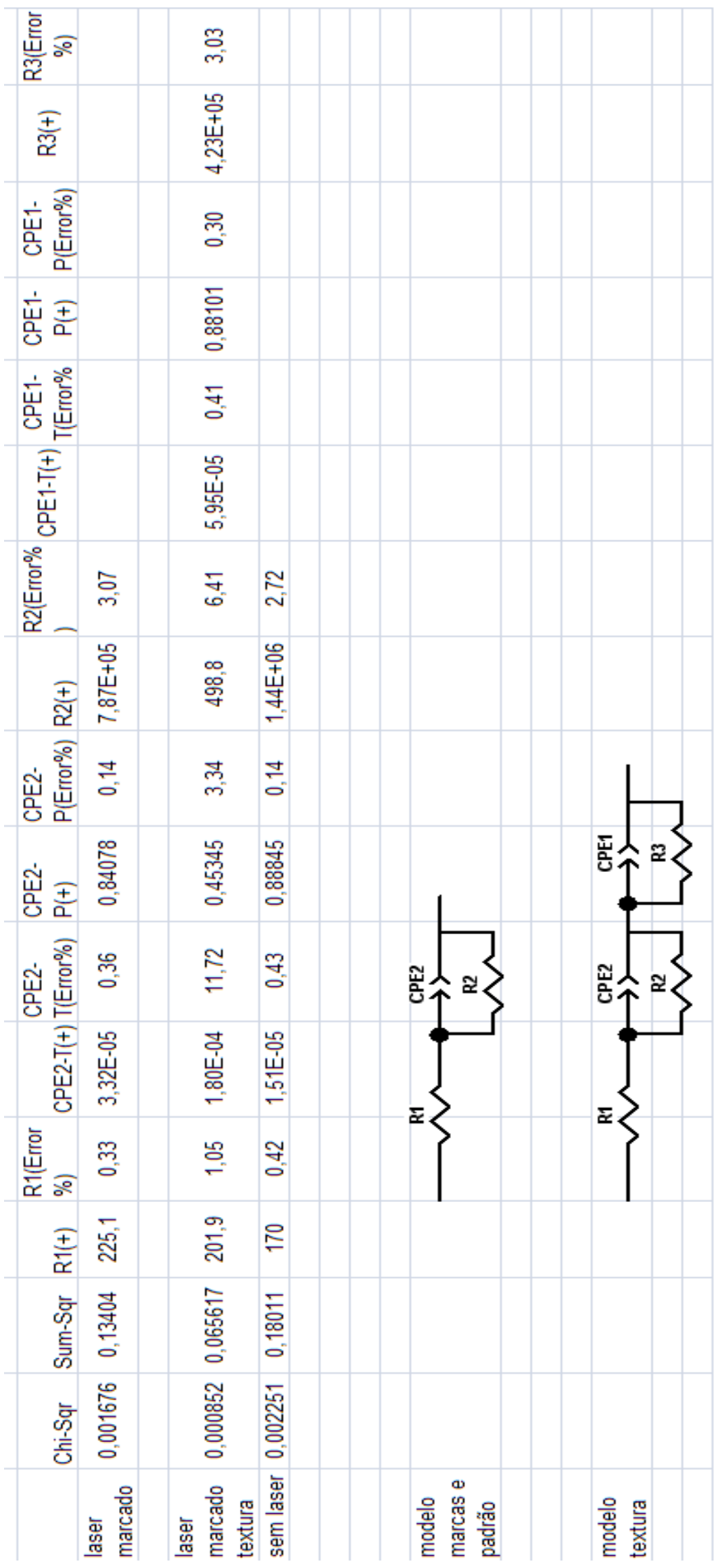



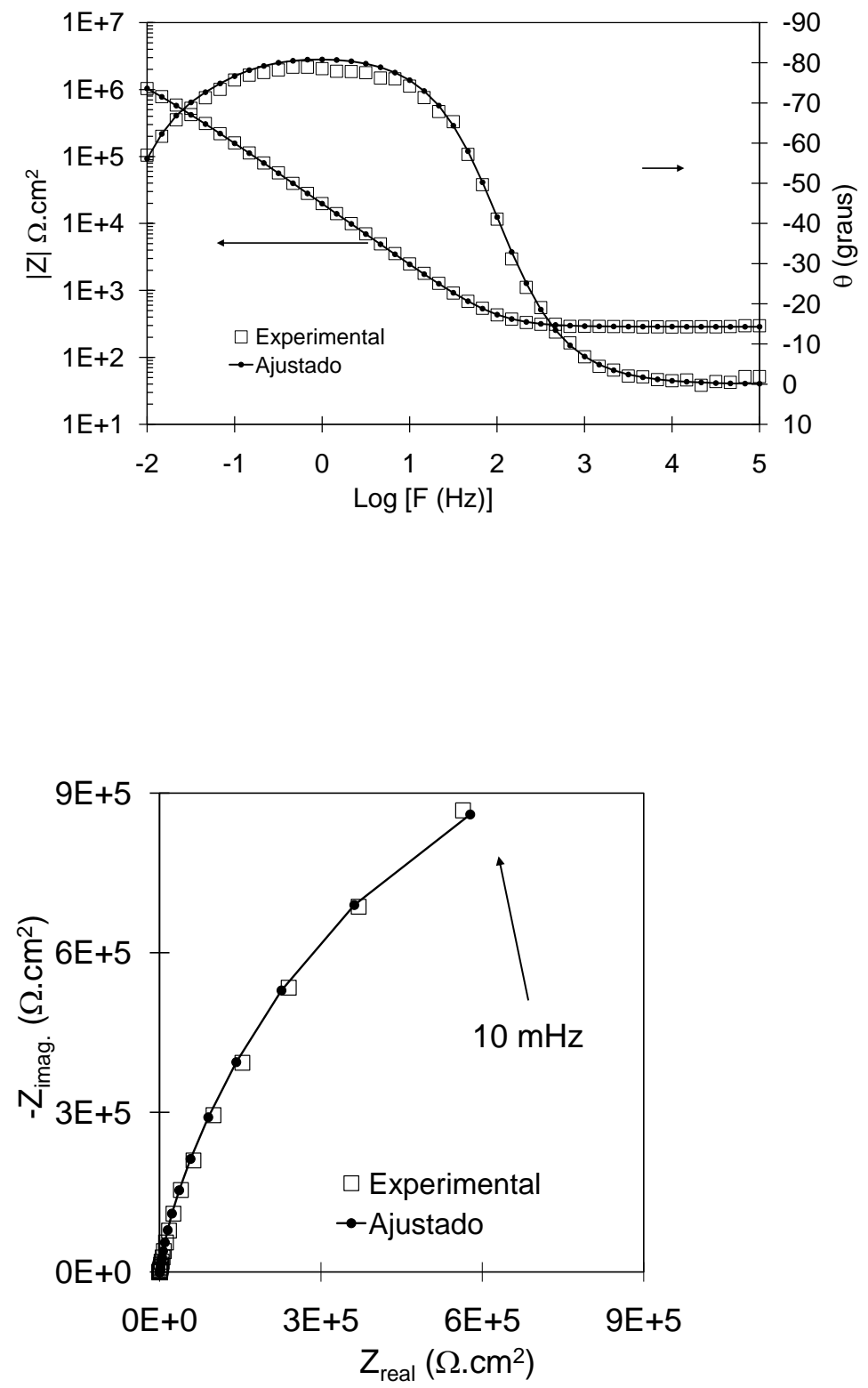

Figura 13. Ajustes para os diagramas de Bode e de Nyquist para as amostras: sem laser (padrão) e marcadas a laser, respectivamente. 

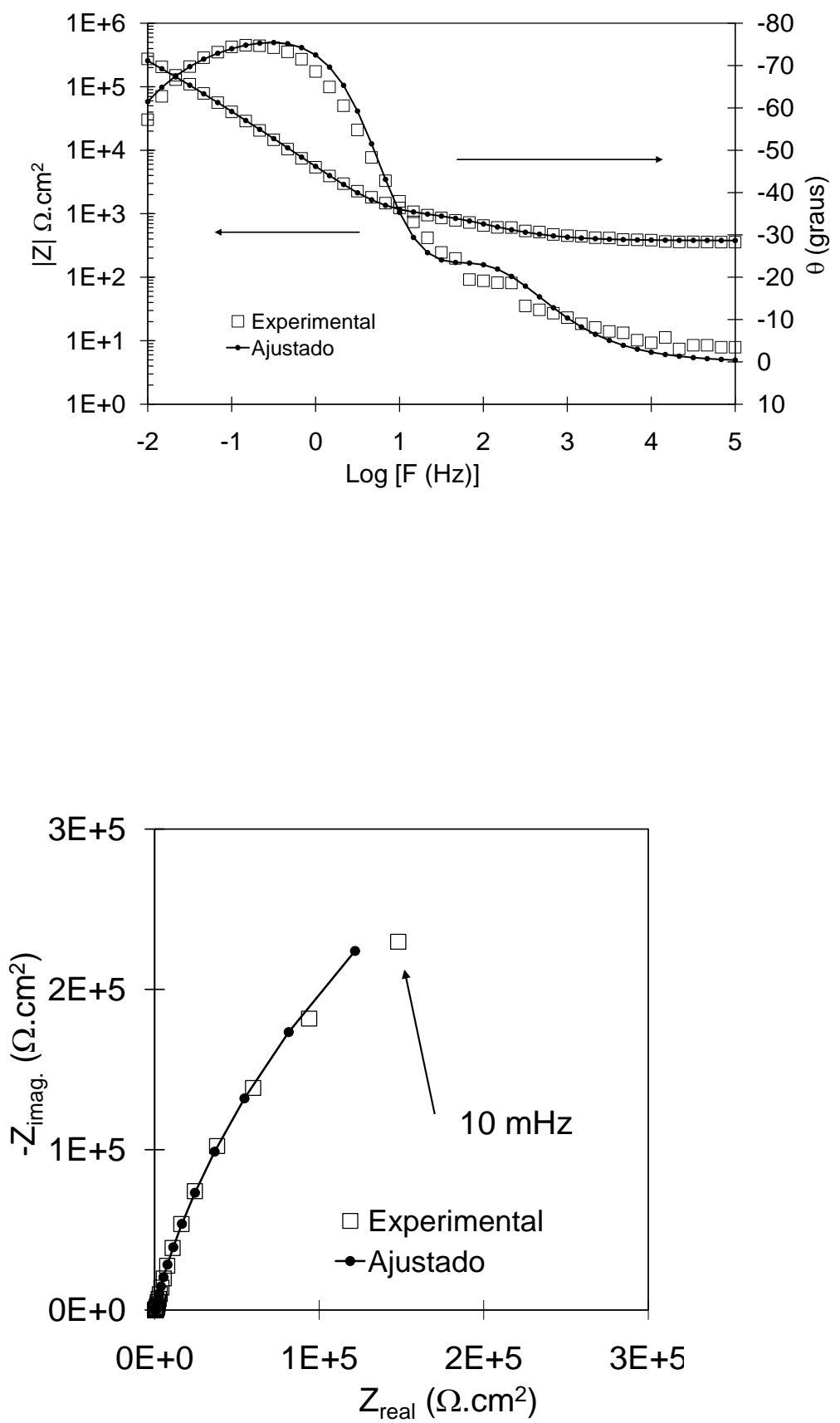

Figura 14. Ajustes para os diagramas de Bode e de Nyquist para as amostras: sem laser (padrão) e texturizadas a laser, respectivamente. 


\section{REFERÊNCIAS BIBLIOGRÁFICAS}

[1] PIERETTI, E. F., Efeito da marcação na resistência à corrosão de implantes ortopédicos produzidos em aço inoxidável ABNT NBR ISO 5832-1. 2012. Dissertação (Mestrado em Tecnologia Nuclear - Materiais) - Instituto de Pesquisas Energéticas e Nucleares, Universidade de São Paulo, São Paulo, 2012.

[2] PIERETTI, E. F., COSTA, I., Surface characterisation of ASTM F139 stainless steel marked by laser and mechanical techniques, Electrochimica Acta, v. 114, p. $838-843,2013$.

[3] PIERETTI, E. F., MANHABOSCO, S. M., DICK, L. F. P., HINDER, S., COSTA, I., Localized corrosion evaluation of the ASTM F139 stainless steel marked by laser using scanning vibrating electrode technique, X-ray photoelectron spectroscopy and Mott-Schottky techniques, Electrochimica Acta, v. 124, p. 150 155, 2014.

[4] LYMAN, D. J., SEARE, Jr, W. J., Biomedical materials in surgery, Materials Science, v.4, p. 415-433,1974.

[5] WILLIAMS, D. F., Corrosion of implant materials, Materials Science, v. 6, p. 237-266, 1976.

[6] GIBBONS, D. F., Biomedical materials, Biophisics and Bioengineering, v. 4, p. 367-375, 1975.

[7] HENCH, L. L., Prosthetic implant materials, Materials Science, v. 5, p. 279-300, 1975.

[8] ANDERSON, J. M., Biological response to materials, Materials Research, v. 31, p. 81-110, 2001.

[9] OLIVEIRA, L. P., PENTEAdO, L. O. S., Análise química e estrutural de implantes ortopédicos de aço inoxidável, Revista Brasileira de Ortopedia, 2004.

[10] VILLAMIL, R.F.V., ARANHA, H., AFONSO, M.L.C. de A., MERCADANTE, M.T., AGOSTINHO, S.M.L., Aços inoxidáveis em implantes ortopédicos: fundamentos e resistência à corrosão. Revista Brasileira de Ortopedia, v. 37, p. 471-476, 2002.

[11] GIORDANI, E. J., FERREIRA, I., BALANCIN, O., Propriedades mecânicas e de corrosão de dois aços inoxidáveis austeníticos utilizados na fabricação de implantes ortopédicos. REM - Revista da Escola de Minas, v. 60, n.1, p.55-62, 2007.

[12] GIORDANI, E. J., FAlleiROS, N. A., FERREIRA, I., BALANCIN, O., Electrochemical behavior of two austenitic stainless steel biomaterials, REM Revista da Escola de Minas, v. 63, p.159-166, 2010. 
[13] NARUSHIMA, T.; MINETA, S.; KURIHARA, Y.; UEDA, K., Precipitates in biomedical Co-Cr Alloys, JOM, v. 65, n. 4, 2013.

[14] BALDAN, M. R.; FERREIRA, N. G.; CAIRO, C.A.A.; PIORINO NETO, F., Aspectos relacionados à obtenção e à caracterização de titânio com porosidade tridimensional. Revista Brasileira de Aplicações de Vácuo, v.27, n. 3, p. 119-124, 2008.

[15] GOIA, T. S.; VIOLIN, B. K.; YOSHIMOTO, M.; BRESSIANI, J. C.;BRESSIANI, A. H., Osseointegration of titanium alloy macroporousimplants obtained by PM with addition of gelatin. Advances in Science and Technology, v. 76, p. 259-263, 2010.

[16] RYAN, G., PANDIT, A., APATSIDIS, D. P., Fabrication methods of porous metals for use in orthopaedic applications. Biomaterials, v. 27, n. 13, p. 2651 , 2006.

[17] VASCONCELlOS, L. M. R., OLIVEIRA, M. V., GRAÇA, M. L. A., VASCONCELlOS, L. G. O., CAIRO, C. A. A., CARVALHO, Y. R. C., Porous titanium scaffolds produced by powder metallurgy for biomedical applications. Mater. Res., v. 11, n. 3, p. 275-280, 2008.

[18] FARIA, P. E. P., CARVALHO, A. L., FELIPUCCI, D. N. B., WEN, C., SENNERBY, L, SALATA, L. A., Bone formation following implantation of titanium sponge rods into humeral osteotomies in dogs: A histological and histometrical study. Clin. Implant. Dent. Relat. Res., v. 12, n. 1, p. 72-79, 2010.

[20] CALLISTER Jr, W. D., Ciência e Engenharia de Materiais: Uma Introdução, Rio de Janeiro, LTC, 2002.

[21] HONG, T., NAGUMO, M., Effect of surface roughness on early stages of pitting corrosion of type 301 stainless steel, Corrosion Science, v. 39, p. 16651672, 1997.

[22] PATRIKAR, R. M., Modeling and simulation of surface roughness, Applied Surface Science, v. 228, p. 213-220, 2004.

[23] LEE, S. M.; LEE, W. G.; KIM, Y. H.; JANG, H., Surface roughness and the corrosion resistance of $21 \mathrm{Cr}$ ferritic stainless steel, Corrosion Science, v. 63, p. 404-409, 2012.

[24] POURBAIX, M., KLIMZACK-MATHIEU, L., MERTERNS, C., MEUNIER, J., VANLUEGEN-HAGHE, C., de MUNCK, L., LAUREYS, J., NEELEMANS, L., WARZEE, M., Potentionkinectic and corrosimetric investigations of the corrosion behavior of alloy steels, Corrosion Science, v. 3, p. 239-259, 1963.

[25] ABNT NBR 12932: 2010, Implantes para cirurgia - Materiais metálicos Preparação de superfície e marcação.

[26] YOUNG, H. D.; Freedman, R. Física IV. 10.ed. São Paulo: Pearson, 2004. 
[27] HITZ , B.; EWING, J. J.; HECHT, J. Introduction to laser technology. 3 rd ed. New York: IEEE, 2000.

[28] TRUMPF LASER MARKING SYSTEMS AG. Trumark Station 5000. Portugal, 2014.

[29] QI, J., WANG, K. L., ZHU, Y. M., A study on the laser marking process of stainless steel, Journal of Materials Processing Technology, v. 139, p. 273-276, 2003.

[30] LEONE, C., GENNA, S., CAPRINO, G., DE IORIO, I., AISI 304 stainless steel marking by a Q-switched diode pumped Nd:YAG laser, v. 210, 1293-1303, 2010.

[31] BIZI-BANDOKI, P., BENAYOUN, S., VALETTE, S., BEAUGIRAUD, B., AUDOUARD, E., Modifications of roughness and wettability properties of metals induced by femtosecond laser treatment, Applied Surface Science, v. 257, p. 5213-5218, 2011.

[32] VAletTE, S., STEYER, P., RICHARD, L., FOREST, B., DONNET, C., AUDOUARD, E., Influence of femtosecond laser marking on the corrosion resistance of stainless steels, Applied Surface Science, v. 252, p. 4696-4701, 2006.

[33] SORIANO, C., LEUNDA, J., LAMBARRI, J., GARCÍA NAVAS, V., SANZ, C., Effect of laser surface hardening on the microstructure, hardness and residual stresses of austempered ductile iron grades, Applied Surface Science, v. 257, p. 7101-7106, 2011.

[34] DIACI, J., BRAČUN, D., GORKIČ, A., MOŽINA. J., Rapid and flexible laser marking and engraving of tilted and curved surfaces, Optics and Lasers in Engineering, v. 49, p. 195-199, 2011.

[35] COFFIN, Jr.,L. F., Fatigue, Materials Science, v. 2, p. 313-348, 1972.

[36] SPEIDEL, M.O. Corrosion Fatigue, Environment-sensitive Fracture, v. 3, ETH Zurich, Switzerland, 1971.

[37] NIINOMI, M., Fatigue characteristics of metallic biomaterials, International Journal of Fatigue, v. 29, p. 992-1000, 2007.

[38] TEOH, S. H., Fatigue of biomaterials: a review, International Journal of Fatigue, v. 22, p. 825-837, 2000.

[39] GIORDANI, E.J., Propriedades, microestruturas e mecanismos de nucleação de trincas por fadiga de dois aços inoxidáveis austeníticos utilizados como biomateriais. Campinas: FEM/UNICAMP, 2001. (Tese de Doutorado).

[40] GIORDANI, E.J., GUIMARÃES, V.A., PINTO, T. B., FERREIRA, I., Effect of precipitates on the corrosion-fatigue crack initiation of ISO 5832-9 stainless steel biomaterial, International Journal of Fatigue, v.26, p.1129-1136, 2004. 
[41] GIL, F.J., DELGADO, L., ESPINAR, E., LLAMAS, J.M., Corrosion and corrosion-fatigue behavior of $\mathrm{cp}-\mathrm{Ti}$ and Ti-6Al-4V laser-marked biomaterials, Journal of Materials Science: Materials in Medicine, v. 23, p. 885-890, 2012.

[42] DUISABEAU, L., COMBRADE, P., FOREST, B., Environmental effect on fretting of metallic materials for orthopaedic implants, Wear, v. 256, p. 805-816, 2004.

[43] SUN, D., WHARTON, J. A., WOOD, R. J. K., Micro-abrasion mechanisms of cast CoCrMo in simulated body fluids, Wear, v. 267, p. 1845-1855, 2009.

[44] WOOD, R. J. K., SUN, D., THAKARE, M. R., ROZAS, A. F., WHARTON, J. A., Interpretation of electrochemical measurements made during micro-scale abrasion-corrosion, Tribology International, v. 43, p. 1218-1227, 2010.

[45] DIOMIDIS, N., MISCHLER, S., MORE, N. S., ROY, M., Tribo-electrochemical characterization of metallic biomaterials for total joint replacement, Acta Biomaterialia, v. 8, p. 852-859, 2012.

[46] VERMILYEA, D.A., Corrosion Science, Materials Science, v. 1, p. 373-398, 1971.

[47] MARCUS, P., Surface science approach of corrosion phenomena, Electrochemica Acta, v.43, n1/2, p. 109-118, 1998.

[48] HAKIKI, N.E., Da CUNHA BELO, M., SIMÕES, A.M.P., FERREIRA, M.G.S., Semiconducting properties of passive films formed on stainless steels, J. Electrochem. Soc. v. 145, p. 3821-3829, 1998.

[49] CASTLE,J.E., CLAYTON, C.R., The use of $x$-ray photo-electron spectroscopy in the analyses of passive layers on stainless steel, Corrosion Science, v. 17, p. 726, 1977.

[50] HAKIKI, N.E., MONTEMOR, M.F., FERREIRA, M.G.S., Da CUNHA BELO,M., Semiconducting properties of thermally grown oxide films on AISI 304 stainless steel, Corrosion Science, v. 42, p. 687-702, 2000.

[51] Da CUNHA BELO, M., HAKIKI, N. E., M, FERREIRA, M.G.S., Semiconducting properties of passive films formed on nickel-base alloys type Alloy 600: influence of the alloying elements, Electrochimica Acta, v. 44, p. 2473-2481, 1999.

[52] TAVEIRA, L. V., MONTEMOR, M. F., Da CUNHA BELO, M., FERREIRA, M. G., DICK, L. F.P., Influence of incorporated Mo and $\mathrm{Nb}$ on the Mott-Schottky behaviour of anodic films formed on AISI 304L, Corrosion Science, v. 52, p. 2813-2818, 2010.

[53] HAKIKI, N. E., BOUDIN, S., RONDOT, B., Da CUNHA BELO, M., The electronic structure of passive films formed on stainless steels, Corrosion Science, v. 37, p. 1809-1822, 1995. 
[54] SCHMUKI, P., BÖHNI, H., BARDWELL, J.A., In situ characterization of anodic silicon oxide films by ac impedance measurements, Journal of the Electrochemical Society, v. 142, p. 1705-1712, 1995.

[55] MONTEMOR, M.F., FERREIRA, M.G.S., HAKIKI, N.E., Da CUNHA BELO, M., Chemical composition and electronic structure of the oxide films formed on $316 \mathrm{~L}$ stainless steel and nickel based alloys in high temperature aquous environments, Corrosion Science, v. 42, p. 1635-1650, 2000.

[56] TOOR, I., Mott-Schottky analysis of passive films on $\mathrm{Si}$ containing stainless steel alloys, J. Electrochem. Soc., v. 158, p. C391-C395, 2011.

[57] DAROWICKI, K., KRAKOWIAK, S., SLEPSKI, P., Selection of measurement frequency in Mott-Schottky analysis of passive layer on nickel, Electrochimica Acta, v. 51, p. 2204-2208, 2006.

[58] GUO, H. X., LU, B. T., LUO, J. L., Study on passivation and erosionenhanced corrosion resistance by Mott- Schottky analysis, Electrochimica Acta, v. 52, p. 1108-1116, 2006.

[59] PYUN, S., KIM, C., Determination of donor concentrarion in anodically passivating polycrystalline $\mathrm{TiO}_{2}$ films from analysis of nonlinear Mott-Schottky plots, Int. J. Hydrogen Energy, v. 16, p. 661-664, 1991.

[60] BONORA, P. L., DEFLORIAN, F., FEDRIZZI, L., Electrochemical impedance spectroscopy as a tool for investigating underpainting corrosion, Electrochimica Acta, v. 41, p. 1073-1082, 1996.

[61] ZOSKI, C. G., Ultramicroelectrodes: Design, fabrication, and characterization, electroanalysis, v. 14, p. 1041-1051, 2002.

[62] ISAACS, H. S., The measurement of the galvanic corrosion of soldered copper using the scanning vibrating electrode technique, Corrosion Science, v. 28, p. $547-558,1988$.

[63] WIPF, D. O., WIGHTMAN, R. M., Submicrosecond measurements with cyclic voltammetry, Analytical Chemistry, v. 60, p. 2460-2464, 1988.

[64] WIPF, D. O., WIGHTMAN, R. M., Voltammetry with microvoltammetric electrodes in resistive solvents under linear diffusion conditions, Analytical Chemistry, v. 62, p. 98-102, 1990.

[65] BARD, A. J., FAN, F. F., KWAK, J., LEV, O., Scanning electrochemical microscopy. Introduction and principles, v. 61, p. 132-138, 1989.

[66] JAFFE, L. F., NUCCITELLI, R., An ultrasensitive vibrating probe for measuring steady extracellular currents, The Journal of Cell Biology, v. 63, p. 614628, 1974. 
[67] ISAACS, H. S., The effect of height on the current distribution measured with a vibrating electrode probe, Journal of Electrochemical Society, v. 138, p. 722-727, 1991.

[68] VUILLEMIN, B., PHILIPPE, X., OLTRA, R., VIGNAL, V., COUDREUSE, L., DUFOUR, L. C., FINOT, E., SVET, AFM and AES study of pitting corrosion initiated on MnS inclusions by microinjection, Corrosion Science, v. 45, p. 11431159, 2003.

[69] TRINH, D., MAISONHAUTE, E., VIVIER, V., Electrical cross-talk in transient mode of scanning electrochemical microscopy, Electrochemistry Communications, v. 16, p. 49-52, 2012.

[70] BUCKWALTER, J.A., WOO, S., Soft-tissue aging and muskoloskeletal function, Journal of Bone and Joint Surgery, v. 10, p. 1533, 1993.

[71] BRONZINO, J.D., The Biomedical Engineering Handbook, Second Edition, v. 1, 2000.

[72] CRISTOFOLINI, L., ERANI, P., GRUPP, T., JANSSON, V., VICECONTI, M., In vitro long-term fatigue endurance of the secondary "cement injection stem" hip prosthesis, Artificial Organs, v. 31 (6), p. 441-451, 2007.

[73] BENEDETTI, M.G., CATANI, F., BILATTA, T.W., MARCACCI, M., MARIANI, E., GIANNINI, S., Muscle activation pattern and gait biomechanics after total knee replacement, Clinical Biomechanics, v. 18, p. 871-876, 2003.

[74] ABNT NBR 15613-2: 2010, Implantes para cirurgia - Resistência à corrosão Parte 2: Determinação de suscetibilidade à corrosão de pequenos componentes Medida de polarização potenciodinâmica cíclica.

[75] AHN, S.J., KWON, H. S., Effects of solution temperature on electronic properties of passive film formed on $\mathrm{Fe}$ in $\mathrm{pH} 8.5$ borate buffer solution, Electrochimica Acta, v. 49, p. 3347-3353, 2004.

[76] Kim, K. S.; Winograd, N., Chemical Physics Letters, v. 30, p. 954, 1978.

[77] Gelius, U., Physica Scripta, v. 9, p. 133, 1974.

[78] Fadley, C. S., Basic Concepts of X-ray Photoelectron Spectroscopy, in Electron Spectroscopy II, Academic Press, Londres, 1979.

[27] HITZ, B.; EWING, J. J.; HECHT, J., Introduction to laser technology. 3 rd ed. New York: IEEE, 2000.

[79] Ferri, F. A.; Silva, M. A. P.; Marega Jr.; E. Magnetic Force Microscopy: Basic Principles and Applications, in Atomic Force Microscopy - Imaging, Measuring and Manipulating Surfaces at the Atomic Scale. 1 st ed. Croatia: Intech, 2012. 
[80] ISO 10993-12:2012, Biological evaluation of medical devices - Part 12: Sample preparation and reference materials.

[81] STAŠIĆ, J.; GAKOVIĆ, B.; PERRIE, W.; WATKINS, K.; PETROVIĆ, S.; TRTICA, M., Surface texturing of the carbon steel AISI 1045 using femtosecond laser in single pulse and scanning regime, Applied Surface Science, v. 258, p. 290-296, 2011.

[82] LIMA, M. S. F.; VIEIRA Jr, N. D.; MORATO, S. P.; VENCOVSKY, P., Microstructural changes due to laser ablation of oxidized surfaces on an AISI M2 tool steel, Materials Science and Engineering A, v. 344, p. 1-9, 2003.

[83] KI, H.; SO, S., Process map for laser heat treatment of carbon steels, Optics \& Laser Technology, v. 44, p. 2106-2114, 2012.

[84] POURBAIX, M., Electrochemical corrosion of metallic biomaterials, Biomaterials, v. 5, p. 122-133, 1984.

[85] MANSFELD, F., SHIH, H., Detection of pitting with electrochemical impedance spectroscopy, Journal of Electrochemical Society, p. 1171-1172, 1988.

[86] TRETHEWEY, K. R., PATON, M., Electrochemical impedance behaviour of type 304L stainless steel under tensile loading, Materials Letters, v. 58, p. 33813384, 2004.

[87] KRAKOWIAK, S., DAROWICKI, K., SLEPSKI, P., Impedance investigation of passive 304 stainless steel in the pit pre-initiation state, Electrochimica Acta, v. 50, p. 2699-2704, 2005.

[88] MANSFELD, F., Electrochemical impedance spectroscopy (EIS) as a new tool for investigating methods of corrosion protection, Electrochimica Acta, v. 35, p. 1533-1544, 1990.

[89] PIERETTI, E. F.; PESSINE, E. J.; CORRÊA, O. V.; ROSSI, W.; NEVES, M. D. M., Effect of Laser Parameters on the Corrosion Resistance of the ASTM F139 Stainless Steel, International Journal of Electrochemical Science (Online), v. 10, p. 1221-1232, 2015.

[90] PIERETTI, E. F. ; COSTA, I. ; MARQUES, R. A. ; LEIVAS, T. P. ; NEVES, M. D. M., Electrochemical Study of a Laser Marked Biomaterial in Albumin Solution, International Journal of Electrochemical Science (Online), v. 9, p. 3828-3836, 2014.

[91] PIERETTI, E. F.; PALATNIC, R. P. ; LEIVAS, T. P. ; COSTA, I. ; NEVES, M. D. M., Evaluation of Laser Marked ASTM F 139 Stainless Steel in Phosphate Buffer Solution with Albumin, International Journal of Electrochemical Science (Online), v. 9, p. 2435-2444, 2014.

[92] FENG, Z., CHENG, X., DONG, C., XU, L., LI, X., Passivity of 316L stainless steel in borate buffer solution studied by Mott-Schottky analysis, atomic absorption 
spectrometry and x-ray photoelectron spectroscopy, Corrosion Science, v. 52, p. 3646-3653, 2010.

[93] PASCHALIS, V., GIAKAS, G., BALTZOPOULOS, V., JAMURTAS, A. Z., THEOHARIS, V., KOTZAMANIDIS, C., KOUTEDAKIS, Y., The effects of muscle damage following eccentric exercise on gait biomechanics, Gait \& Posture, v. 25, p. 236-242, 2007.

[94] MILES, A. W., GHEDUZZI, S., Basic biomechanics and biomaterials, Surgery, v. 27:2, p. 90-95, 2008.

[95] LIU, F., FISHER, J., JIN, Z., Effect of motion inputs on the wear prediction of artificial hip joints, Tribology International, v. 63, p. 105- 114, 2013.

[96] STEENSEN, R. N., DOPIRAK, R. M., McDONALD, W. G., The anatomy and isometry of the medial patelofemoral ligament -Implications for reconstruction, The American Journal of Sports Medicine, v. 32, n. 6, p. 1509-1513, 2004.

[97] LAPRADE, R. F., TSO, A., WENTORF, F. A., Force measurements on the fibular collateral ligament, popliteofibular ligament, and popliteus tendon to applied loads, The American Journal of Sports Medicine, v. 32, n. 7, p. 1695-1701, 2004.

[98] BRADBURY, N., BORTON, D., SPOO, G., CROSS, M. J., Participation in sports after total knee replacement, The American Journal of Sports Medicine, v. 26, n. 4, p. 530-535, 1998.

[99] ASTM E8 / E8M - 11, Standard Test Methods for Tension Testing of Metallic Materials, ASTM International, West Conshohocken, PA, 2011.

[100] ASTM E466-15, Standard Practice for Conducting Force Controlled Constant Amplitude Axial Fatigue Tests of Metallic Materials, ASTM International, West Conshohocken, PA, 2015.

[101] ASTM E467-08, Standard Practice for Verification of Constant Amplitude Dynamic Forces in an Axial Fatigue Testing System, ASTM International, West Conshohocken, PA, 2014.

[102] ABNT NBR 15613-16, Implantes para cirurgia - Resistência à corrosão Parte 3: Ensaio de corrosão sob fadiga axial de materiais metálicos, 2016.

[103] ADACHI, K., HUTCHINGS, I. M., Wear-mode mapping for the micro-scale abrasion test, Wear, v. 255, p. 23-29, 2003.

[104] STACHOWIAK, G. B., STACHOWIAK, G. W., CELLJERS, O., Ball-cratering abrasion tests of high-Cr white cast irons, Tribology International, v. 38, p. 10761087, 2005.

[105] STACHOWIAK,G. B., STACHOWIAK, G. W., BRANDT, J. M., Ball-cratering abrasion tests with large abrasive particles, Tribology International, v. 39, p. 1-11, 2006. 
[106] RUTHERFORD, K. L., HUTCHINGS, I. M., Theory and application of a micro-scale abrasive wear test, Journal of Testing and Evaluation, v.25 (2), p. 250260, 1997.

[107] COZZA, R. C., TANAKA, D. K. Tanaka, SOUZA, R. M., Friction coefficient and abrasive wear modes in ball-cratering tests conducted at constant normal force and constant pressure - Preliminary results, Wear, v. 267, p. 61-70, 2009.

[108] COZZA, R. C., MELO, J. D. B., TANAKA, D. K., SOUZA, R. M., Relationship between test severity and wear mode transition in micro-abrasive wear tests, Wear, v. 263, p. 111-116, 2007.

[109] TREZONA, R. I., ALLSOPP, D. N., HUTCHINGS, I. M., Transitions between two-body and three-body abrasive wear: influence of test conditions in the microscale abrasive wear test, Wear, v. 229, p. 205-214, 1999.

[110] OKASAKI, Y., Effect of friction on anodic polarization properties of metallic biomaterials, Biomaterials, v. 23, p. 2071-2077, 2002.

[111] HUANG, C., ZHANG, Y., VILAR, R., SHEN, J., Dry sliding wear behavior of laser clad TiVCrAISi high entropy alloy coatings on Ti-6Al-4V substrate, Materials and Design, v. 41, p. 338-343, 2012.

[112] MARTIN, R. V.; DIAS, R. R.; ARRUDA, I., Magnetismo em padrões de massa de elevada qualidade, Congresso de Qualidade em MetrologiaENQUALAB, São Paulo, junho, 2009.

[113] WARREN, A. D., HARNIMAN, R. L., COLLINS, A. M., DAVIS, S. A., YOUNES, C. M., FLEWIT, P. E. J., SCOTT, T. B., Comparison between magnetic force microscopy and electron back-scatter diffraction for ferrite quantification in type 321 stainless steel, Ultramicroscopy, v. 148, p. 1-9, 2015.

[114] GADELRAB, K. R., LI, G., CHISEA, M., SOUIER, T., Local characterisation of austenite and ferrite phases in duplex stainless steel using MFM and nanoindentation, Journal of Material Research, v. 27, p. 1573-1579, 2012. 